\title{
Enantioselective Hydroalkenylation of Olefins with Enol Sulfonates Enabled by Dual Copper Hydride and Palladium Catalysis
}

\author{
Alexander W. Schuppe, James Levi Knippel, Gustavo M. Borrajo-Calleja and Stephen L. \\ Buchwald* \\ Department of Chemistry, Massachusetts Institute of Technology, Cambridge, Massachusetts \\ 02139, United States \\ Correspondence to: sbuchwal@mit.edu
}




\section{Table of Contents}

1. General Experimental Details SI3-SI4

2. Optimization of the Reaction Conditions SI5-SI8

3. Synthesis and Characterization of Starting Materials SI9

3.1. Synthesis and Characterization of $\mathrm{Pd}($ cinnamyl $)(\mathrm{Cl})(\mathrm{dpbbz})(\mathbf{P 1})$ SI9

3.2. Synthesis and Characterization of Alkenyl Coupling Partners SI10-SI16

3.3. Synthesis and Characterization of Vinyl Arenes and Terminal Olefins SI17-SI23

4. Synthesis and Characterization of Hydroalkenylation Products $\mathrm{SI} 24$

4.1. General Procedure $C$ for Hydroalkenylation of Olefins SI24-SI27

4.2. General Procedure D for Purification by Reversed-Phase Chromatography

4.3. Characterization of Enantioselective Hydroalkenylation Products $\mathrm{SI} 28$

4.4. Reduction of $3 \mathbf{x}$ to $(S)$-Gamfexine (4) SI29-SI43

4.5. Large Scale Bench Top Setup SI44-SI45

4.6. Characterization of Hydroalkenylation of Unactivated Olefin Products.

SI46-SI47

4.7. Additional Hydroalkenylation Products and Data

SI48-SI52 SI53

5. References and Notes

SI54-SI55

6. Associated Analytical Data SI56

6.1. NMR Spectra of Starting Materials for Olefin Hydroalkenylation SI56-SI84

6.2. NMR Spectra of Olefin Hydroalkenylation Products SI85-SI134

6.3. Chiral SFC and HPLC Traces of Olefin Hydroalkenylation Products SI135-SI164 
Supporting Information

\section{General Experimental Details}

General Experimental Procedures: All reactions were performed in flame-dried or oven-dried glassware fitted with rubber or PTFE/silicone septa under a positive pressure of nitrogen, unless otherwise noted. Standard reactions were performed in glass culture tubes with threaded ends (Fisherbrand, $16 \times 125 \mathrm{~mm}$, catalog no. $1495935 \mathrm{~A}$; oven-dried at $140{ }^{\circ} \mathrm{C}$ ) that were sealed with screw-thread caps (Kimble Chase Open Top S/T Closure, catalog no. 73804-15425) fitted with PTFE/SIL septa (Thermo Scientific, catalog no. B7995-15). Air- and moisture-sensitive liquids were transferred via syringe or stainless-steel cannula through rubber or PTFE/silicone septa. Solids were added under inert gas counter flow or were dissolved in the appropriate solvent. Reactions carried out at temperatures above room temperature (rt) were conducted in a pre-heated oil bath. All reactions were magnetically stirred and monitored by ${ }^{1} \mathrm{H}$ NMR spectroscopy or analytical thin-layer chromatography (TLC), using glass-backed plates pre-coated with silica gel (250 $\mu \mathrm{m}, 60-\AA$ pore size, Extra Hard Layer, SiliaPlate) impregnated with a fluorescent indicator $(254 \mathrm{~nm})$. TLC plates were visualized by exposure to ultraviolet light (UV), or were stained by submersion in iodine dispersed in sand $\left(\mathrm{I}_{2}\right)$, an acidic solution of cerium ammonium molybdate (CAM) or in aqueous potassium permanganate solution $\left(\mathrm{KMnO}_{4}\right)$ and were developed by heating with a heat gun. Preparative thin-layer chromatography was performed using glass-backed plates pre-coated with silica gel $(1000 \mu \mathrm{m}, 60-\AA$ pore size, Extra Hard Layer, SiliaPlate) impregnated with a fluorescent indicator (254 nm). Flash column chromatography was performed using SiliCycle SiliaFlash ${ }^{\circledR}$ F60 silica gel (40-63 $\mu \mathrm{m}, 230-400$ mesh, $60-\AA$ pore diameter) or with the aid of a Biotage Isolera or a Teledyne ISCO CombiFlash Automated Flash Chromatography System using prepacked SNAP silica cartridges (10-100 g). Reversed-phase column chromatography was performed with the aid of a Teledyne ISCO CombiFlash Automated Flash Chromatography System using prepacked SNAP C18 cartridges (40-100 g).

Materials: Unless noted otherwise, all reagents and starting materials were purchased from commercial sources and used as received (Millipore-Sigma, Alfa Aesar, Strem, TCl-America, Combi-Blocks, or Matrix Scientific). $\mathrm{CDCl}_{3}$ was purchased from Cambridge Isotope Laboratories. Tetrahydrofuran (THF), diethyl ether $\left(\mathrm{Et}_{2} \mathrm{O}\right)$, toluene $(\mathrm{PhMe})$ and dichloromethane $\left(\mathrm{CH}_{2} \mathrm{Cl}_{2}\right)$ were obtained from J.T. Baker in CYCLE-TAINER $囚$ delivery kegs and purified by successive filtrations though packed columns of neutral alumina and $\mathrm{CuO}$ under argon pressure. Solvents for extraction, crystallization and flash column chromatography were purchased in A.C.S. reagent grade from Millipore-Sigma, with the exception of hexane, which was purchased in HPLC grade. Lithium bis(trimethylsilyl)amide (LiHMDS) was purchased from Millipore-Sigma as a $1.0 \mathrm{M}$ solution in PhMe (Sure/Seal ${ }^{\mathrm{TM}}$ ). (S)-DTBM-MeO-BIPHEP and biarylphosphine ligands were generous gifts from Solvias and Millipore-Sigma, respectively. The yields refer to chromatographically and spectroscopically $\left({ }^{1} \mathrm{H}\right.$ and ${ }^{13} \mathrm{C}$ NMR) pure material.

Instrumentation: NMR spectra were measured on Bruker Avance III HD 400, 500, or $600 \mathrm{MHz}$, spectrometers. Proton chemical shifts are expressed in parts per million (ppm, $\delta$ scale) and are referenced to the residual proton in the NMR solvent $\left(\mathrm{CDCl}_{3}: \delta 7.26\right) .{ }^{1} \mathrm{H}$ NMR spectroscopic data are reported as follows: Chemical shift in ppm (multiplicity, coupling constants $J(\mathrm{~Hz})$, integration intensity, assigned proton). The multiplicities are abbreviated with $\mathrm{s}$ (singlet), br s (broad singlet), $\mathrm{d}$ (doublet), t (triplet), q (quartet), hept (heptet) $\mathrm{m}$ (multiplet), a (apparent). All ${ }^{13} \mathrm{C}$ spectra recorded are proton-decoupled. The carbon chemical shifts are expressed in parts per million (ppm, $\delta$ scale) and are referenced to the carbon resonance of the NMR solvent $\left(\mathrm{CDCl}_{3}: \delta 77.16\right)$. ${ }^{13} \mathrm{C} \mathrm{NMR}$ spectroscopic data are reported as follows: Chemical shift in ppm (multiplicity, coupling constants $J(\mathrm{~Hz})$, assigned carbon). All ${ }^{19} \mathrm{~F}$ and ${ }^{31} \mathrm{P}$ spectra were acquired without proton-decoupling. The ${ }^{19} \mathrm{~F}$ and ${ }^{31} \mathrm{P}$ chemical shifts are expressed in parts per million $(\mathrm{ppm}, \delta$ scale. All raw fid files were processed and the spectra analyzed using the program MestReNOVA 14.2 from Mestrelab 
Research S. L. High-resolution mass spectra were recorded on a JEOL AccuTOF LC-Plus 46 with an ionSense DART system and on an Agilent Technologies 6550 Q-TOF LC/MS system using an Agilent Zorbax 300 SB-C3 (2.1 × $150 \mathrm{~mm}$, 5- $\mu \mathrm{m}$ particle size). IR spectra were recorded on a Nicolet iS5 spectrometer equipped with an iD5 diamond laminate ATR accessory from Thermo Scientific. IR spectra were acquired from neat samples. If required, substances were dissolved in $\mathrm{CH}_{2} \mathrm{Cl}_{2}$ prior to direct application on the ATR unit. Data are reported as follows: frequency of absorption $\left(\mathrm{cm}^{-1}\right)$. Melting points were determined on an EZ-Melt capillary melting point apparatus from SRS Stanford Research System. The values are uncorrected. Elemental analyses were performed by Atlantic Microlabs Inc., Norcross, GA, USA. Specific optical rotations were recorded for chloroform solutions at a standard concentration of $10 \mathrm{mg} / \mathrm{mL}$ using a Jasco 1010 polarimeter operating at $589 \mathrm{~nm}$ and $23{ }^{\circ} \mathrm{C}$. Enantiomeric ratio (er) was determined either by chiral HPLC analysis using Agilent 1200 Series chromatographs or by Chiral SFC using a Waters Acquity UPC2 instrument equipped with $250 \mathrm{~mm} \times 4.6 \mathrm{~mm}$ columns containing chiral stationary phases; specific columns and analytic methods are provided in the experimental details for individual compounds; the wavelengths of light used for chiral analyses are provided with the associated chromatograms. 


\section{Optimization of the Reaction Conditions}

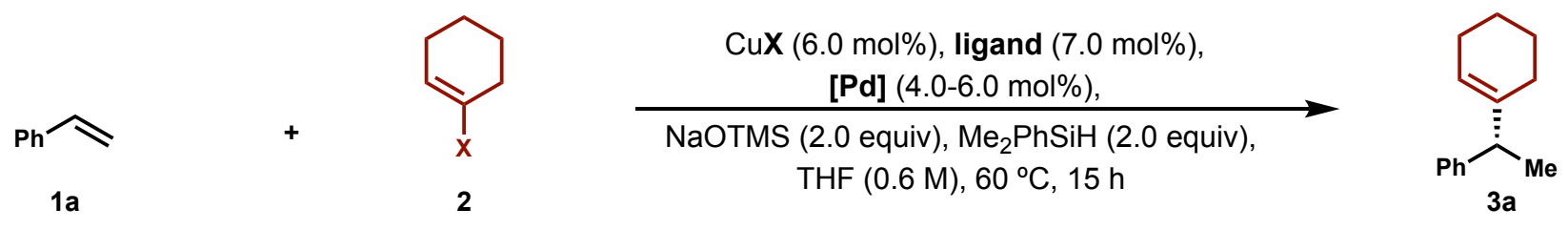

Inside a nitrogen-filled glovebox, an oven-dried reaction tube, (tube A) (Fisherbrand, $13 \times 100 \mathrm{~mm}, 1495935 \mathrm{C}$ ) equipped with a magnetic stir bar was charged with the corresponding

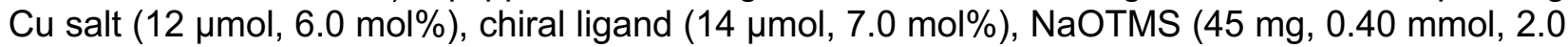
equiv) and THF (0.2 mL).

Simultaneously, in another oven-dried reaction tube, (tube B) (Fisherbrand, 13x100 mm, $1495935 \mathrm{C}$ ) equipped with a magnetic stir bar was charged with Pd source (12 $\mu \mathrm{mol}, 6.0 \mathrm{~mol} \%$ [Pd]), ligand (12 $\mu \mathrm{mol}, 6.0 \mathrm{~mol} \%)$ and THF $(0.15 \mathrm{~mL})$.

After the reaction mixture had stirred for $10 \mathrm{~min}$ at room temperature, $\mathrm{Me}_{2} \mathrm{PhSiH}(61 \mu \mathrm{L}$, $0.40 \mathrm{mmol}, 2.0$ equiv) was added to reaction tube $\mathrm{A}$ using a glass air-tight syringe and the reaction mixture was allowed to stir for $10 \mathrm{~min}$. To the reaction mixture was added styrene $(21 \mathrm{mg}, 0.20$ mmol, 1.0 equiv) and the reaction mixture was allowed to stir for $2 \mathrm{~min}$. Then the entirety of the Pd solution, from reaction tube $\mathbf{B}$, was added to reaction tube $\mathbf{A}$ using a glass air-tight syringe. Once the resulting reaction mixture had stirred for an additional 2 min, the alkenyl coupling partner $(0.30$ mmol, 1.5 equiv) was added. Test tube $\mathbf{A}$ was sealed with a screw cap containing a PTFE septum, taken outside the glovebox and the reaction tube was placed in an oil bath preheated to $60^{\circ} \mathrm{C}$.

After the reaction mixture had stirred for $15 \mathrm{~h}$ at $60^{\circ} \mathrm{C}$, the reaction vessel was removed from the oil bath and allowed to cool to room temperature. The crude reaction mixture was diluted with EtOAc $(2 \mathrm{~mL})$ and filtered through a glass pipette (Kimble, 5-3/4" Glass Monster Pipette) containing a $1 \mathrm{~cm}$ plug of Celite, which was subsequently washed with EtOAc $(2 \times 2 \mathrm{~mL})$. The combined filtrate was transferred to a 5 dram vial, then concentrated in vacuo with the aid of a rotary evaporator. The crude reaction yield was evaluated by ${ }^{1} \mathrm{H}$ NMR with 1,1,2,2tetrachloroethane (TCE) $(21 \mu \mathrm{L}, 0.20 \mathrm{mmol}, 1.0$ equiv) as an internal standard. A small portion of the crude reaction mixture was purified by preparatory silica thin layer chromatography, and the resulting purified product was analyzed by chiral SFC to determine enantioselectivity.

Note: If a pre-ligated Pd source was employed, such as P1, reaction tube $\mathbf{B}$ is unnecessary and the Pd-precatalyst was added directly to reaction tube $\mathbf{A}$ as a solid, following the addition of styrene. 
Table SI1: Optimization of the ligand for Pd and Pd source. ${ }^{a}$

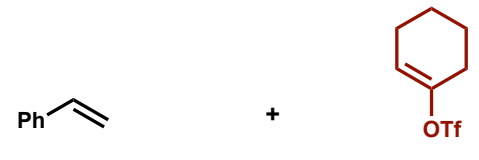

$1 \mathrm{a}$

(1.0 equiv)

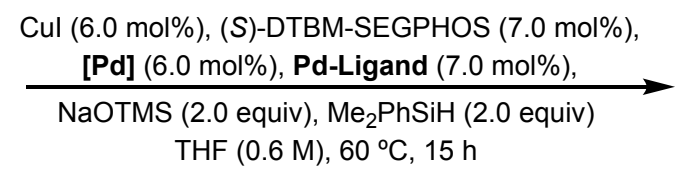

$\operatorname{THF}(0.6 \mathrm{M}), 60^{\circ} \mathrm{C}, 15 \mathrm{~h}$

(1.5 equiv)

\begin{tabular}{lllll}
\multicolumn{7}{c}{$(1.5$ equiv $)$} & & & \\
\hline Entry & Pd-Ligand & {$[$ Pd $]$} & ${ }^{1} \mathrm{H}$ NMR yield & er \\
\hline 1 & BrettPhos & {$[\mathrm{Pd}(\text { cinnamyl })(\mathrm{Cl})]_{2}$} & $14 \%$ & nd \\
2 & XPhos & {$[\mathrm{Pd}(\text { cinnamyl })(\mathrm{Cl})]_{2}$} & $12 \%$ & nd \\
3 & CPhos & {$[\mathrm{Pd}(\text { cinnamyl })(\mathrm{Cl})]_{2}$} & $16 \%$ & nd \\
4 & SPhos & {$[\mathrm{Pd}(\text { cinnamyl })(\mathrm{Cl})]_{2}$} & $9 \%$ & nd \\
5 & RuPhos & {$[\mathrm{Pd}(\text { cinnamyl })(\mathrm{Cl})]_{2}$} & $7 \%$ & nd \\
6 & JackiePhos & {$[\mathrm{Pd}(\text { cinnamyl })(\mathrm{Cl})]_{2}$} & $25 \%$ & nd \\
7 & Xantphos & {$[\mathrm{Pd}(\text { cinnamyl })(\mathrm{Cl})]_{2}$} & $31 \%$ & nd \\
8 & dppf & {$[\mathrm{Pd}(\text { cinnamyl })(\mathrm{Cl})]_{2}$} & $17 \%$ & nd \\
9 & dppbz & {$[\mathrm{Pd}(\text { cinnamyl })(\mathrm{Cl})]_{2}$} & $75 \%$ & $96: 4$ \\
10 & dppbz & $\mathrm{Pd}(\mathrm{OAC})_{2}$ & $61 \%$ & $87: 13$ \\
11 & $\mathrm{dppbz}$ & $\mathrm{Pdl}{ }_{2}$ & $64 \%$ & $96: 4$ \\
\hline
\end{tabular}

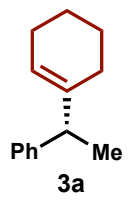

3a

${ }^{a}$ Reaction conditions: $0.2 \mathrm{mmol}$ styrene (2a) (1.0 equiv), yields were determined by ${ }^{1} \mathrm{H}$ NMR spectroscopy of the crude reaction mixture, using 1,1,2,2-tetrachloroethane as an internal standard. Enantiomeric ratio (er) was determined by chiral SFC.

Scheme SI1: Employing a Pd-precatalyst (P1) in model reaction. ${ }^{a}$

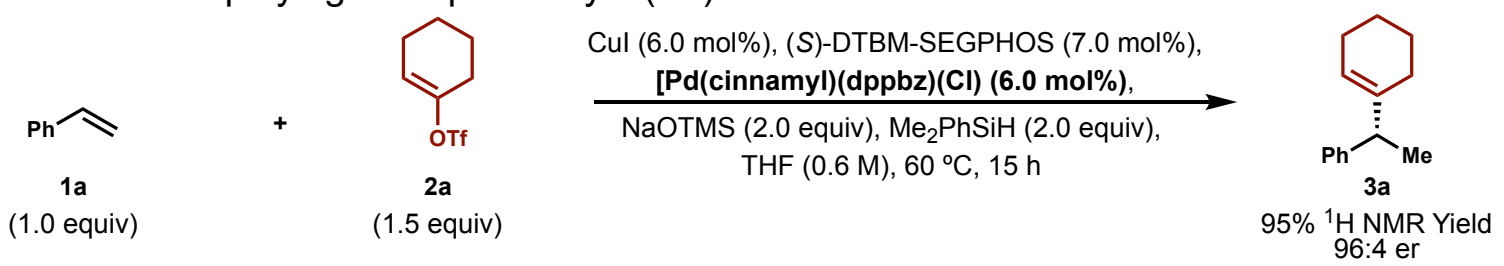

${ }^{a}$ Reaction conditions: $0.2 \mathrm{mmol}$ styrene (2a) (1.0 equiv), yields were determined by ${ }^{1} \mathrm{H}$ NMR spectroscopy of the crude reaction mixture, using 1,1,2,2-tetrachloroethane as an internal standard. Enantiomeric ratio (er) was determined by chiral SFC. 
Table SI2: Optimization of the chiral ligand and Cu salt. ${ }^{a}$
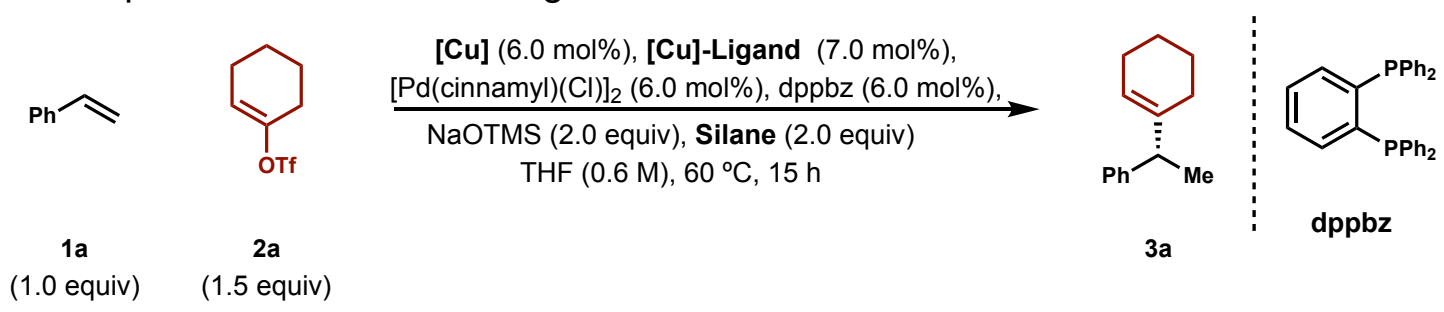

\begin{tabular}{|c|c|c|c|c|c|}
\hline Entry & [Cu]-Ligand & {$[\mathrm{Cu}]$} & Silane & ${ }^{1} \mathrm{H}$ NMR yield & er \\
\hline 1 & (S)-DTBM-SEGPHOS & CuOAc & $\mathrm{Me}(\mathrm{Ph})_{2} \mathrm{SiH}$ & $29 \%$ & $88: 12$ \\
\hline 2 & (S)-DTBM-SEGPHOS & $\mathrm{CuCl}$ & $\mathrm{Me}(\mathrm{Ph})_{2} \mathrm{SiH}$ & $10 \%$ & nd \\
\hline 3 & (S)-DTBM-SEGPHOS & $\mathrm{CuBr}$ & $\mathrm{Me}(\mathrm{Ph})_{2} \mathrm{SiH}$ & $55 \%$ & $86: 14$ \\
\hline 4 & (S)-DTBM-SEGPHOS & Cul & $\mathrm{Me}(\mathrm{Ph})_{2} \mathrm{SiH}$ & $67 \%$ & $86: 14$ \\
\hline 5 & (S)-DTBM-SEGPHOS & Cul & $\mathrm{Me}_{2}(\mathrm{Ph}) \mathrm{SiH}$ & $75 \%$ & $96: 4$ \\
\hline 6 & (R)-DTBM-Garphos & Cul & $\mathrm{Me}_{2}(\mathrm{Ph}) \mathrm{SiH}$ & $9 \%$ & nd \\
\hline 7 & (S)-DTBM-MeO-BIPHEP & Cul & $\mathrm{Me}_{2}(\mathrm{Ph}) \mathrm{SiH}$ & $94 \%$ & $96: 4$ \\
\hline $8^{b}$ & (S)-DTBM-MeO-BIPHEP & Cul & $\mathrm{Me}_{2}(\mathrm{Ph}) \mathrm{SiH}$ & $90 \%$ & $96: 4$ \\
\hline
\end{tabular}

(S)-DTBM-SEGPHOS

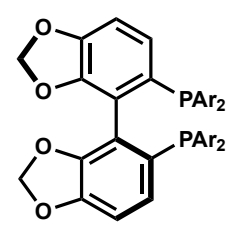

L1
(R)-DTBM-Garphos

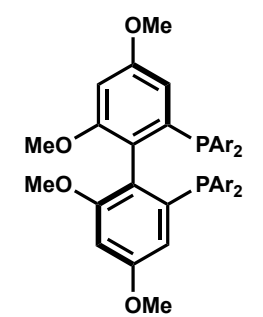

(S)-DTBM-MeO-BIPHEP

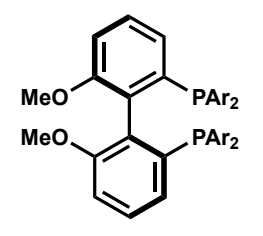

L2

$\mathrm{Ar}=3,5-(t-\mathrm{Bu})_{2}-4-\mathrm{MeOC}_{6} \mathrm{H}_{2} \quad \mathrm{Ar}=3,5-(t-\mathrm{Bu})_{2}-4-\mathrm{MeOC}_{6} \mathrm{H}_{2} \quad \mathrm{Ar}=3,5-(t-\mathrm{Bu})_{2}-4-\mathrm{MeOC}_{6} \mathrm{H}_{2}$

${ }^{a}$ Reaction conditions: $0.2 \mathrm{mmol}$ styrene (2a) (1.0 equiv), yields were determined by ${ }^{1} \mathrm{H}$ NMR spectroscopy of the crude reaction mixture, using 1,1,2,2-tetrachloroethane as an internal standard. Enantiomeric ratio (er) was determined by chiral SFC. ${ }^{b}$ Using $2.0 \mathrm{~mol} \%$ of [Cu] and [Pd]. 
Table SI3: Comparison of enol triflates and tosylates. ${ }^{a}$
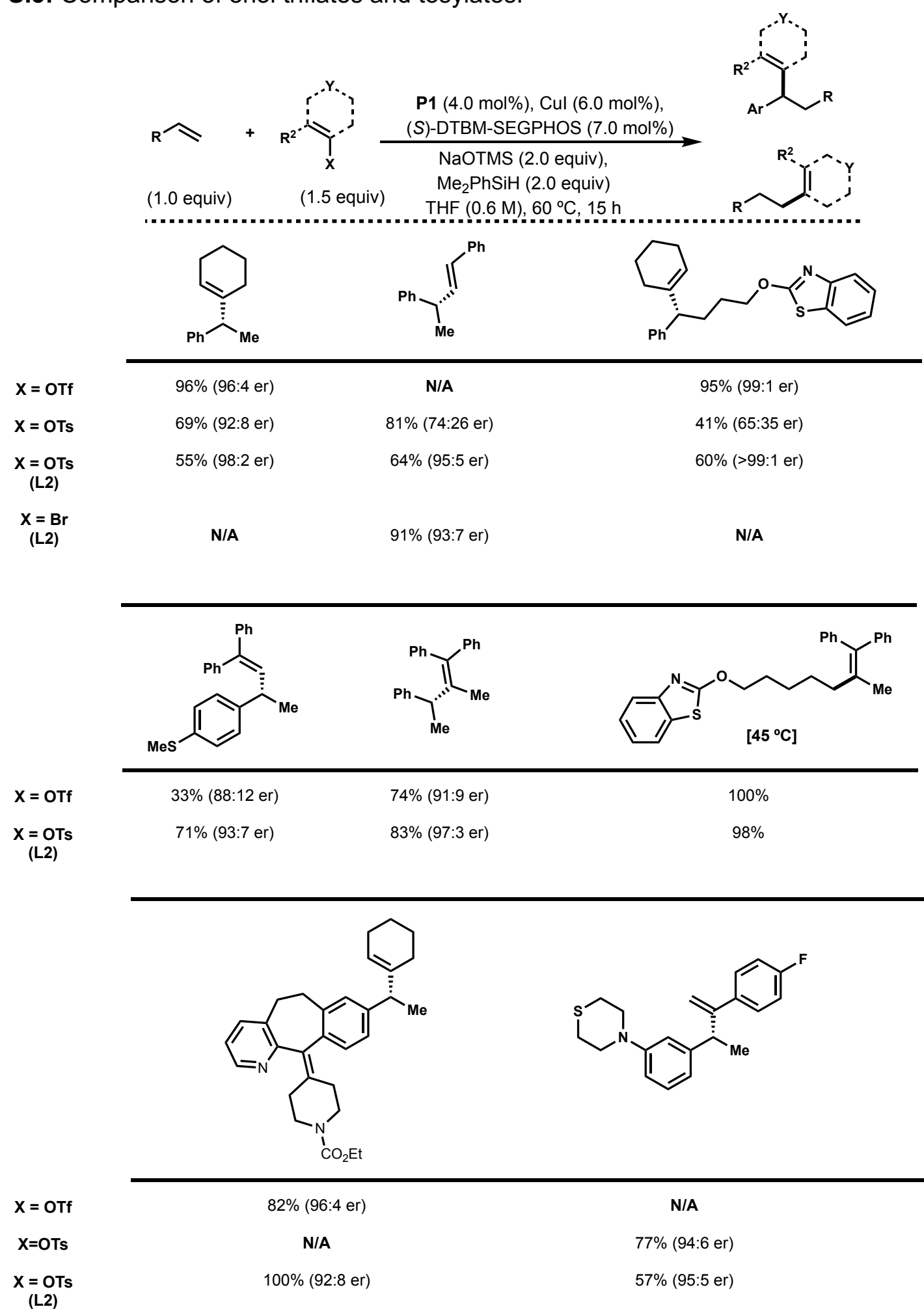

${ }^{a}$ Reaction conditions: $0.2 \mathrm{mmol}$ alkene (1.0 equiv), yields were determined by ${ }^{1} \mathrm{H}$ NMR spectroscopy of the crude reaction mixture, using 1,1,2,2-tetrachloroethane as an internal standard. Enantiomeric ratio (er) was determined by chiral SFC. 


\section{Synthesis and Characterization of Starting Materials}

\subsection{Synthesis and Characterization of $\mathrm{Pd}($ cinnamyl)(Cl)(dpbbz) (P1)}

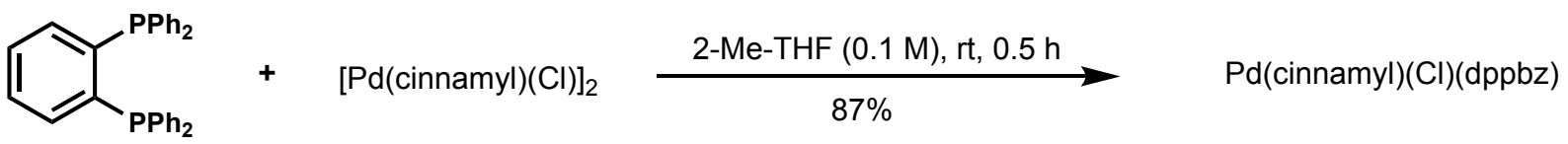

(2.0 equiv)

(1.0 equiv)

(P1)

\section{Pd(cinnamyl)(Cl)(dppbz) (P1)}

Inside a nitrogen-filled glovebox, a $50 \mathrm{~mL}$ round-bottom flask equipped with an egg-shaped magnetic stir bar was charged with $[\mathrm{Pd}(\text { cinnamyl })(\mathrm{Cl})]_{2}(1.00 \mathrm{~g}, 1.93 \mathrm{mmol}, 1.0$ equiv), dppbz (1.72 $\mathrm{g}, 3.86 \mathrm{mmol}, 2.0$ equiv) and 2-Me-THF $(20 \mathrm{~mL}, 0.1 \mathrm{M})$, resulting in a red-orange-colored reaction mixture. After ca. $5 \mathrm{~min}$, an orange precipitate had formed. The flask was sealed with a rubber septum and removed from the glovebox. Once on the bench top, the mixture was opened to the air by removing the septum, diluted with pentane $(10 \mathrm{~mL})$ and filtered through a glass fritted funnel. The solid was further washed with pentane $(2 \times 15 \mathrm{~mL})$, the filtrate was discarded. The solid was transferred to a $20 \mathrm{~mL}$ scintillation vial and dried in vacuo on a Schlenk line overnight resulting in P1 $(1.19 \mathrm{~g}, 87 \%)$ as a yellow-orange solid.

${ }^{1} \mathrm{H}$ NMR $\left(\mathrm{CDCl}_{3}, 400 \mathrm{MHz}\right): \delta 7.64-7.35(\mathrm{~m}, 16 \mathrm{H}), 7.34-7.20(\mathrm{~m}, 5 \mathrm{H}), 7.19-6.95(\mathrm{~m}, 8 \mathrm{H}), 6.45(\mathrm{q}$, $J=11.4 \mathrm{~Hz}, 1 \mathrm{H}), 5.81(\mathrm{t}, J=11.6 \mathrm{~Hz}, 1 \mathrm{H}), 4.12(\mathrm{t}, J=9.8 \mathrm{~Hz}, 2 \mathrm{H})$.

${ }^{13} \mathrm{C} \mathrm{NMR}\left(\mathrm{CDCl}_{3}, 101 \mathrm{MHz}\right): \delta 137.4(\mathrm{p}, J=3.0 \mathrm{~Hz}), 134.2(\mathrm{dd}, J=36.2,14.7 \mathrm{~Hz}), 134.0$ (s), 133.5 (dd, $J=26.4,13.2 \mathrm{~Hz}$ ), 132.4 (t, $J=5.5 \mathrm{~Hz}$ ), 131.2 (dd, $J=35.3,2.6 \mathrm{~Hz}$ ), 130.9 (s), 130.5 (s), 129.2 (dd, $J=33.0,10.8 \mathrm{~Hz}), 128.6(\mathrm{t}, J=1.9 \mathrm{~Hz}), 127.2(\mathrm{t}, J=2.5 \mathrm{~Hz}), 126.6(\mathrm{t}, J=3.2 \mathrm{~Hz}), 118.4$ (t, $J=7.1 \mathrm{~Hz}), 98.7$ (dd, $J=24.4,7.7 \mathrm{~Hz}$ ).

${ }^{31} \mathrm{P}$ NMR $\left(\mathrm{CDCl}_{3}, 162 \mathrm{MHz}\right): \delta 49.02,43.61$.

IR (Diamond-ATR, neat) $\widetilde{v}_{\max }: 3052,1677,1587,1475,1435,1103,746,736,689$.

HRMS (ESI-TOF) m/z: [M-Cl] ${ }^{+}$calcd. for $\mathrm{C}_{39} \mathrm{H}_{33} \mathrm{P}_{2} \mathrm{Pd}^{+}:$669.1087. Found: 669.1112.

Melting Point $\left({ }^{\circ} \mathrm{C}\right): 133-142$ (decomposition).

Note: The Pd-precatalyst (P1) was stable on the bench top for $>6$ months with no special precautions. No loss of catalytic activity was noted after this time. 


\subsection{Synthesis and Characterization of Alkenyl Coupling Partners}

\section{The following coupling partners were prepared according to known protocols or purchased:}
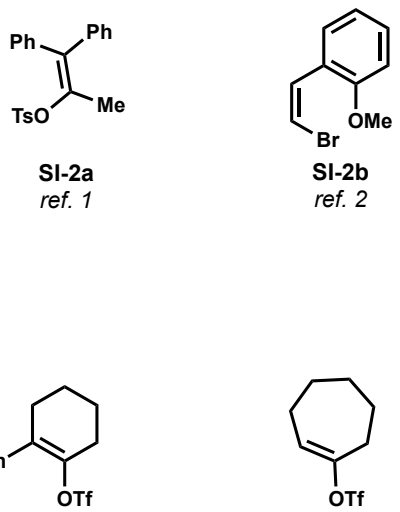

SI-2g

ref. 6

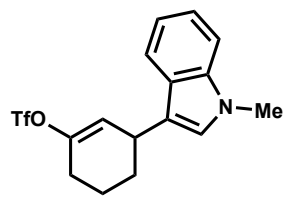

SI-2I

ref. 10 ref. 7

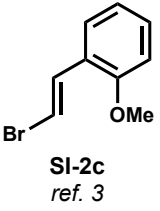<smiles>C=C(O[Sb])c1ccc(F)cc1</smiles>

SI-2d<smiles>BrN1CC[C+]CC1</smiles>

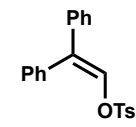

SI-2e
ref. 5

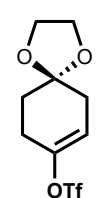

SI-2i<smiles>COC1=CC2=CC[C@@H]3[C@H](CC[C@]4(C)[C@H]3CC[C@]4(C)[C@@H](C)CCCC(C)C)[C@@]2(C)CC1</smiles>

SI-2j<smiles>Cc1ccc(C2=C(O)c3ccccc3CCC2)cn1</smiles>

SI-2k<smiles>CC(C)C1CC[C@@H](C)C=C1O</smiles><smiles>CC(O)=C(C)P</smiles><smiles>Oc1ccccc1</smiles><smiles>OC1=CCOCC1</smiles><smiles>[O+]N1C=CC(O)CC1</smiles>

SI-2n

ref. 1

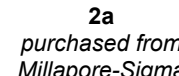

Sl-2o
purchased from
Combi-Blocks

SI-2p

purchased from Combi-Blocks

\section{General Procedure A: Preparation of Enol Triflates}<smiles>[R]CC([R])=O</smiles>

$\mathrm{SI}-1$
LiHMDS (1.1 equiv), Comins' reagent (1.05 equiv),

$\operatorname{THF}(0.33 \mathrm{M}),-78^{\circ} \mathrm{C} \rightarrow \mathrm{rt}$, $16 \mathrm{~h}$<smiles>[R]C=C([R])[O]</smiles>

SI-2

To an oven-dried $100 \mathrm{~mL}$ round-bottom flask equipped with a magnetic stir bar was added Comins' reagent ( $3.76 \mathrm{~g}, 10.5 \mathrm{mmol}, 1.05$ equiv). The reaction flask was fitted with a rubber septum and connected to a dual manifold Schlenk line by piercing the septum with a needle connected to a rubber hose. The flask was then evacuated/backfilled with $\mathrm{N}_{2}$ (this process was repeated a total of three times). To the reaction mixture was added THF (33 mL, $0.33 \mathrm{M})$ and ketone $(10.0 \mathrm{mmol}$, 1.0 equiv) via syringe (by puncturing the rubber septum). The reaction flask was transferred to a dry ice/ acetone bath cooled to $-78{ }^{\circ} \mathrm{C}$. After stirring for $5 \mathrm{~min}$ at this temperature, a solution of LiHMDS (11.0 mL, $11.0 \mathrm{mmol}, 1.1$ equiv, $1.0 \mathrm{M}$ in $\mathrm{PhMe})$ was added dropwise to the reaction mixture over 5 min via syringe by puncturing the rubber septum. The reaction mixture was allowed to slowly warm to room temperature over $16 \mathrm{~h}$.

After this time, the septum was removed, and the reaction mixture was diluted with sat. aq. $\mathrm{NH}_{4} \mathrm{Cl}(30 \mathrm{~mL}$ ). The mixture was transferred to a separatory funnel and the layers were separated. The aqueous layer was extracted with EtOAc $(3 \times 30 \mathrm{~mL})$. The combined organic layers were washed with brine $(35 \mathrm{~mL})$, dried over $\mathrm{Na}_{2} \mathrm{SO}_{4}$, filtered and concentrated in vacuo with the aid of a rotary evaporator. The crude residue was purified by automated flash column chromatography on silica gel. 


\section{General Procedure B: Pd-catalyzed Arylation of Acetone}<smiles>Brc1ccccc1</smiles>

SI-3

\author{
$\frac{\mathrm{Pd}(\mathrm{OAc})_{2}(2.5 \mathrm{~mol} \%), \text { SPhos }(5 \mathrm{~mol} \%)}{\mathrm{K}_{3} \mathrm{PO}_{4}\left(\begin{array}{c}1.5 \text { equiv }), \text { acetone }(0.6 \mathrm{M}) \\ 90{ }^{\circ} \mathrm{C}, 15 \mathrm{~h}\end{array}\right.}$
}<smiles>CC(=O)Cc1ccccc1</smiles>

SI-1

Procedure adapted from ref. 24

To a $35 \mathrm{~mL}$ threaded high-pressure reaction tube (Ace Glass 8648-07) equipped with magnetic stir bar was added potassium phosphate monohydrate $(3.0 \mathrm{~g}, 13 \mathrm{mmol}, 1.0$ equiv), $\mathrm{Pd}(\mathrm{OAc})_{2}$ (73 mg, $0.33 \mathrm{mmol}, 2.5 \mathrm{~mol} \%$ ), SPhos (267 mg, $0.650 \mathrm{mmol}, 5 \mathrm{~mol} \%$ ), and (hetero)aryl bromide (13 mmol, 1.0 equiv). The tube was fitted with a rubber septum, and then evacuated/refilled with $\mathrm{N}_{2}$ (this process was repeated a total of three times) using a dual manifold Schlenk line. To the reaction vessel was added acetone $(22 \mathrm{~mL}, 0.6 \mathrm{M})$ via syringe by puncturing the rubber septum, and the rubber septum was quickly replaced by a threaded PTFE stopper with a rubber O-ring (Ace Glass \#15 Plug, 5846-48). The reaction tube was then transferred to an oil bath preheated to $90^{\circ} \mathrm{C}$.

After the reaction had stirred for $15 \mathrm{~h}$ at $90^{\circ} \mathrm{C}$, the reaction vessel was removed from the oil bath and allowed to cool to room temperature. Once at room temperature, the PTFE stopper was removed. The reaction mixture was diluted with EtOAc $(10 \mathrm{~mL})$ and filtered into a $250 \mathrm{~mL}$ round-bottom flask through a $2 \mathrm{~cm}$ pad of Celite using a glass fritted funnel. The Celite was subsequently washed with EtOAc $(2 \times 20 \mathrm{~mL})$. The combined filtrate was concentrated in vacuo with the aid of a rotary evaporator. The crude residue was used in General Procedure A without further purification.

\section{7-methoxy-3,4-dihydronaphthalen-2-yl trifluoromethanesulfonate (SI-2q)}<smiles>COc1ccc2c(c1)CC(=O)CC2</smiles>

SI-1a

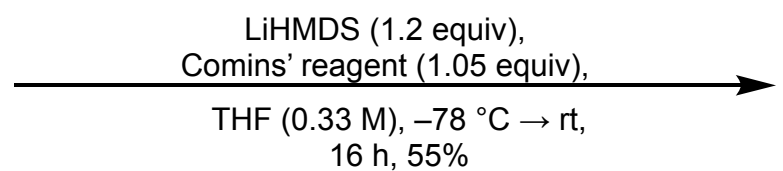

$16 \mathrm{~h}, 55 \%$<smiles>COC1=Cc2cc(OC)ccc2CC1</smiles>

SI-2q

Prepared according to General Procedure A using 7-methoxy-3,4-dihydronaphthalen-2(1H)-one (SI-1a) (1.76 g, $10.0 \mathrm{mmol}, 1.0$ equiv), Comins' reagent (3.76 g, $10.5 \mathrm{mmol}, 1.05$ equiv) and LiHMDS (12.0 mL, $12.0 \mathrm{mmol}, 1.2$ equiv, $1.0 \mathrm{M}$ in PhMe). The residue was purified by automated flash column chromatography on silica gel $\left(50 \mathrm{~g} \mathrm{SiO}_{2}\right.$, hexane to $5 \%$ EtOAc in hexane) to yield SI$2 q$ as an off-white solid (1.69 $\mathrm{g}, 55 \%$ yield).

${ }^{1} \mathrm{H}$ NMR $\left(\mathrm{CDCl}_{3}, 500 \mathrm{MHz}\right): \delta 7.05(\mathrm{~d}, J=8.3 \mathrm{~Hz}, 1 \mathrm{H}), 6.74(\mathrm{dd}, J=8.2,2.7 \mathrm{~Hz}, 1 \mathrm{H}), 6.65(\mathrm{~d}, J=$ $2.6 \mathrm{~Hz}, 1 \mathrm{H}), 6.44(\mathrm{~s}, 1 \mathrm{H}), 3.79(\mathrm{~s}, 3 \mathrm{H}), 2.99(\mathrm{t}, \mathrm{J}=8.2 \mathrm{~Hz}, 2 \mathrm{H}), 2.67(\mathrm{td}, \mathrm{J}=8.3,1.4 \mathrm{~Hz}, 2 \mathrm{H})$.

${ }^{13} \mathrm{C}$ NMR $\left(\mathrm{CDCl}_{3}, 126 \mathrm{MHz}\right): \delta 158.8,150.7,132.3,128.5,125.0,118.8$ (q, J = 320.9 Hz), 118.7, 113.6, 113.2, 55.5, 27.8, 27.1.

${ }^{19} \mathrm{~F}$ NMR $\left(\mathrm{CDCl}_{3}, 471 \mathrm{MHz}\right): \delta-73.54$.

IR (Diamond-ATR, neat) $\widetilde{v}_{\text {max }}:$ 2950, 2838, 1607, 1501, 1419, 1243, 861. 
EA calcd. for $\mathrm{C}_{12} \mathrm{H}_{11} \mathrm{~F}_{3} \mathrm{O}_{4} \mathrm{~S}: \mathrm{C}, 46.75 ; \mathrm{H}, 3.60$. Found: $\mathrm{C}, 46.62 ; \mathrm{H}, 3.53$.

Melting Point $\left({ }^{\circ} \mathrm{C}\right): 42-43$.

\section{(E)-1-(4-methoxyphenyl)prop-1-en-2-yl trifluoromethanesulfonate (SI-2r)}<smiles>COc1ccc(CC(C)=O)cc1</smiles>

SI-1b

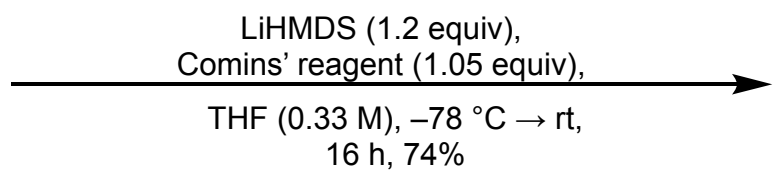

16 h, $74 \%$<smiles></smiles>

SI-2r

Prepared according to General Procedure A using 1-(3-methoxyphenyl)propan-2-one (SI-1b) ( $1.64 \mathrm{~g}, 10.0 \mathrm{mmol}, 1.0$ equiv), Comins' reagent ( $3.76 \mathrm{~g}, 10.5 \mathrm{mmol}, 1.05$ equiv) and LiHMDS (12.0 $\mathrm{mL}, 12.0 \mathrm{mmol}, 1.2$ equiv, $1.0 \mathrm{M}$ in $\mathrm{PhMe}$ ). The crude reaction mixture was observed to be a $6.5: 1$ $E: Z$ ratio of alkene isomers, as determined by ${ }^{1} \mathrm{H}$ NMR. The residue was purified by automated flash column chromatography on silica gel $\left(50 \mathrm{~g} \mathrm{SiO}_{2}\right.$, hexane to $2 \%$ EtOAc in hexane) to yield SI$2 \mathrm{r}(2.18 \mathrm{~g}, 74 \%$ yield $)$ as a colorless oil and a $6.5: 1$ ratio of $E: Z$ alkene isomers.

${ }^{1} \mathrm{H}$ NMR $\left(\mathrm{CDCl}_{3}, 400 \mathrm{MHz}\right)$ : (major isomer, E-alkene) $\delta 7.20(\mathrm{~d}, J=8.7 \mathrm{~Hz}, 2 \mathrm{H}), 6.92(\mathrm{~d}, J=8.8$ $\mathrm{Hz}, 2 \mathrm{H}), 6.56$ (s, 1H), 3.83 (s, 3H), 2.27 (s, 3H).

${ }^{13} \mathrm{C}$ NMR $\left(\mathrm{CDCl}_{3}, 101 \mathrm{MHz}\right)$ : (major isomer, E-alkene) $\delta 159.6,147.0,130.2,124.9,122.5,120.3$, 120.1, 117.1, 114.3, 55.5, 17.9.

${ }^{19} \mathrm{~F}$ NMR $\left(\mathrm{CDCl}_{3}, 376 \mathrm{MHz}\right)$ : (major isomer, E-alkene) $\delta-73.86$.

IR (Diamond-ATR, neat) $\widetilde{\boldsymbol{v}}_{\text {max: }}$ 2981, 2731, 1609, 1513, 1412, 1178, 903, 825.

HRMS (DART) m/z: [M+H] $]^{+}$calcd. for $\mathrm{C}_{11} \mathrm{H}_{12} \mathrm{~F}_{3} \mathrm{O}_{4} \mathrm{~S}^{+}:$297.0403. Found: 294.0416.

\section{1-(benzo[b]thiophen-5-yl)piperidin-4-one (SI-1c)}

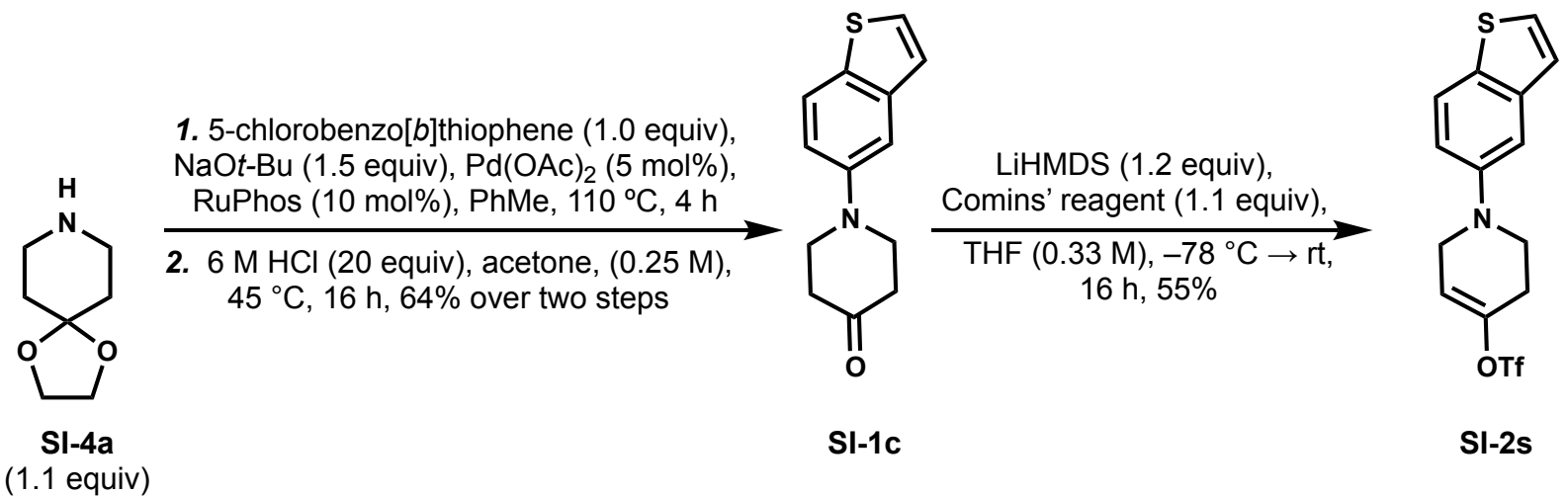

To a flame-dried $100 \mathrm{~mL}$ round-bottom flask equipped with a magnetic stir bar was added $\mathrm{Pd}(\mathrm{OAc})_{2}(110 \mathrm{mg}, 0.50 \mathrm{mmol}, 5 \mathrm{~mol} \%$ ), and RuPhos (467 mg, $1.00 \mathrm{mmol}, 10 \mathrm{~mol} \%$ ). The reaction flask was sealed with a rubber septum, and connected to a dual manifold Schlenk line by piercing the septum with a needle connected to a rubber hose. The apparatus was evacuated/backfilled with $\mathrm{N}_{2}$ (this process was repeated a total of three times). To the reaction flask was added PhMe $(10.0 \mathrm{~mL}, 1.0 \mathrm{M})$ via syringe (by puncturing the rubber septum) and the reaction mixture was allowed to stir for 10 min before the rubber septum was removed and 1,4-dioxa-8azaspiro[4.5]decane (SI-4a) $(1.41 \mathrm{~mL}, 11.0 \mathrm{mmol}, 1.1$ equiv), 5-chlorobenzo[b]thiophene (1.68 $\mathrm{g}$, 
$10.0 \mathrm{mmol}, 1.0$ equiv), and sodium tert-butoxide (1.44 g, $15.0 \mathrm{mmol}, 1.5$ equiv) were added sequentially to the reaction mixture. The reaction flask was then equipped with an oven-dried reflux condenser, sealed with a rubber septum, attached by rubber hose via a needle to a dual manifold Schlenk line, and placed under $\mathrm{N}_{2}$ atmosphere. The reaction apparatus was transferred to an oil bath preheated to $110^{\circ} \mathrm{C}$.

After the reaction mixture had stirred at $110^{\circ} \mathrm{C}$ for $4 \mathrm{~h}$, the reaction vessel was removed from the oil bath and allowed to cool to room temperature. Once at room temperature, the reaction mixture was diluted with sat. aq. $\mathrm{NH}_{4} \mathrm{Cl}(10 \mathrm{~mL})$, transferred to a separatory funnel, and the layers were separated. The aq. layer was extracted with EtOAc $(3 \times 10 \mathrm{~mL})$. The combined organic layers were washed with brine $(20 \mathrm{~mL})$, dried over $\mathrm{Na}_{2} \mathrm{SO}_{4}$, filtered through a $2 \mathrm{~cm}$ pad of Celite using a glass fritted funnel, and concentrated in vacuo with the aid of a rotary evaporator in a $250 \mathrm{~mL}$ round-bottom flask.

To the $250 \mathrm{~mL}$ round-bottom flask containing the resulting crude oil was added a magnetic stir bar, acetone $(40 \mathrm{~mL}, 0.25 \mathrm{M})$ and aq. $6 \mathrm{M} \mathrm{HCl}(33.3 \mathrm{~mL}, 200.0 \mathrm{mmol}, 20.0$ equiv). The reaction flask was equipped with an oven-dried reflux condenser, sealed with a rubber septum, attached by rubber hose via a needle to a dual manifold Schlenk line, and placed under $\mathrm{N}_{2}$ atmosphere. The reaction apparatus was transferred to an oil bath preheated to $45^{\circ} \mathrm{C}$.

After the reaction mixture had stirred at $45^{\circ} \mathrm{C}$ for $16 \mathrm{~h}$, the reaction vessel was removed from the oil bath and allowed to cool to room temperature. Once at room temperature, the reaction mixture was concentrated in vacuo with the aid of a rotary evaporator. The resulting reaction mixture was diluted with EtOAc $(50 \mathrm{~mL})$ and aq. $10 \% \mathrm{NaOH}(75 \mathrm{~mL})$ was slowly added to the reaction mixture over $5 \mathrm{~min}$. The reaction mixture was transferred to a separatory funnel, the layers were separated, and the aqueous layer was extracted with EtOAc $(2 \times 50 \mathrm{~mL})$. The combined organic layers were washed with brine $(50 \mathrm{~mL})$, dried over $\mathrm{Na}_{2} \mathrm{SO}_{4}$, filtered and concentrated in vacuo with the aid of a rotary evaporator. The residue was purified by automated flash column chromatography on silica gel (50 $\mathrm{g} \mathrm{SiO}_{2}$, gradient elution: hexane to $50 \%$ EtOAc in hexane) to yield SI-1c as a tan solid (1.48 $\mathrm{g}, 64 \%$ yield over two steps).

${ }^{1} \mathrm{H}$ NMR $\left(\mathrm{CDCl}_{3}, 500 \mathrm{MHz}\right): \delta 7.77(\mathrm{~d}, J=8.8 \mathrm{~Hz}, 1 \mathrm{H}), 7.43(\mathrm{~d}, J=5.4 \mathrm{~Hz}, 1 \mathrm{H}), 7.36(\mathrm{~d}, J=2.4$ $\mathrm{Hz}, 1 \mathrm{H}), 7.24(\mathrm{~d}, J=5.4 \mathrm{~Hz}, 1 \mathrm{H}), 7.13(\mathrm{dd}, J=8.8,2.5 \mathrm{~Hz}, 1 \mathrm{H}), 3.62(\mathrm{t}, J=6.0 \mathrm{~Hz}, 4 \mathrm{H}), 2.61(\mathrm{t}, J$ $=6.0 \mathrm{~Hz}, 4 \mathrm{H})$.

${ }^{13} \mathrm{C}$ NMR $\left(\mathrm{CDCl}_{3}, 126 \mathrm{MHz}\right): \delta 208.4,147.3,141.0,132.3,127.6,123.7,123.3,116.5,110.1,50.4$, 41.1.

IR (Diamond-ATR, neat) $\widetilde{v}_{\max }: 3068,2959,2814,1709,1598,1264,1208,992,868,692$.

Melting Point $\left({ }^{\circ} \mathrm{C}\right): 106-109$.

EA calcd. for $\mathrm{C}_{13} \mathrm{H}_{13} \mathrm{NOS}$ : C, 67.50; $\mathrm{H}, 5.67$. Found: $\mathrm{C}, 67.21 ; \mathrm{H}, 5.69$.

\section{1-(benzo[b]thiophen-5-yl)-1,2,3,6-tetrahydropyridin-4-yl trifluoromethanesulfonate (SI-2s)}

Prepared according to General Procedure A using 1-(benzo[b]thiophen-5-yl)piperidin-4-one (SI1c) $(759 \mathrm{mg}, 3.28 \mathrm{mmol}, 1.0$ equiv), Comins' reagent (1.29 g, $3.61 \mathrm{mmol}, 1.1$ equiv), THF (10 mL, $0.33 \mathrm{M}$ ) and LiHMDS (3.9 mL, $3.9 \mathrm{mmol}, 1.2$ equiv, $1.0 \mathrm{M}$ in PhMe). The residue was purified by automated flash column chromatography on silica gel $\left(50 \mathrm{~g} \mathrm{SiO}_{2}\right.$, gradient elution: hexane to $65 \%$ EtOAc in hexane) to yield SI-2s as a tan solid (660 $\mathrm{mg}, 55 \%$ yield).

${ }^{1} \mathrm{H}$ NMR $\left(\mathrm{CDCl}_{3}, 400 \mathrm{MHz}\right): \delta 7.76(\mathrm{~d}, J=8.8 \mathrm{~Hz}, 1 \mathrm{H}), 7.43(\mathrm{~d}, J=5.4 \mathrm{~Hz}, 1 \mathrm{H}), 7.32(\mathrm{~d}, J=2.4$ $\mathrm{Hz}, 1 \mathrm{H}), 7.24(\mathrm{~d}, J=5.4 \mathrm{~Hz}, 1 \mathrm{H}), 7.08(\mathrm{dd}, J=8.8,2.4 \mathrm{~Hz}, 1 \mathrm{H}), 5.95-5.91(\mathrm{~m}, 1 \mathrm{H}), 3.88(\mathrm{q}, J=$ $3.1 \mathrm{~Hz}, 2 \mathrm{H}), 3.54$ (t, $J=5.6 \mathrm{~Hz}, 2 \mathrm{H}), 2.66-2.57(\mathrm{~m}, 2 \mathrm{H})$. 
${ }^{13} \mathrm{C}$ NMR $\left(\mathrm{CDCl}_{3}, 101 \mathrm{MHz}\right): \delta 147.4,140.8,132.7,127.6,123.8,123.2,120.3,117.1,116.7,116.1$, 110.5, 48.0, 47.8, 28.5.

${ }^{19} \mathrm{~F} \mathrm{NMR}\left(\mathrm{CDCl}_{3}, 471 \mathrm{MHz}\right): \delta-73.73$.

IR (Diamond-ATR, neat) $\widetilde{v}_{\max }: 2962,1601,1442,1206,1139,882$.

Melting Point $\left({ }^{\circ} \mathrm{C}\right): 81-83$.

EA calcd. for $\mathrm{C}_{14} \mathrm{H}_{12} \mathrm{~F}_{3} \mathrm{NO}_{3} \mathrm{~S}_{2}$ : C, 46.28; $\mathrm{H}, 3.33$. Found: $\mathrm{C}, 46.05 ; \mathrm{H}, 3.27$.

(E)-1-(2-morpholinopyrimidin-5-yl)prop-1-en-2-yl trifluoromethanesulfonate (SI-2t)

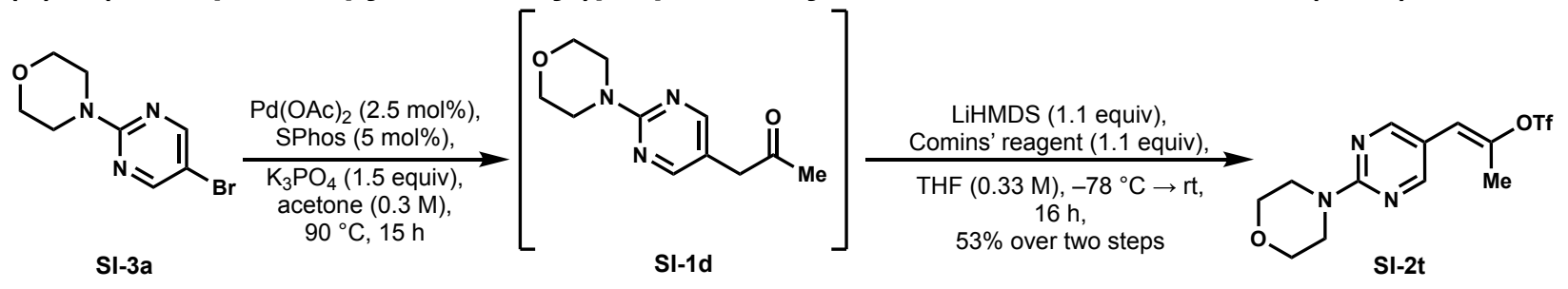

SI-1d was prepared according to General Procedure B, using 4-(5-bromopyrimidin-2yl)morpholine (SI-3a) (732 mg, $3.00 \mathrm{mmol}, 1.0$ equiv), potassium phosphate monohydrate (691 $\mathrm{mg}, 3.00 \mathrm{mmol}, 1.5$ equiv), $\mathrm{Pd}(\mathrm{OAc})_{2}(17 \mathrm{mg}, 75 \mu \mathrm{mol}, 2.5 \mathrm{~mol} \%)$, SPhos (62 mg, $150 \mu \mathrm{mol}, 5$ $\mathrm{mol} \%)$, and acetone $(10 \mathrm{~mL}, 0.3 \mathrm{M})$. The crude residue was used in the subsequent step without further purification.

SI-2t was prepared according to General Procedure A using unpurified SI-1d (3.00 mmol, 1.0 equiv), Comins' reagent (1.3 g, $3.3 \mathrm{mmol}, 1.1$ equiv), THF (9 mL, $0.33 \mathrm{M})$, and LiHMDS (3.3 mL, $3.3 \mathrm{mmol}, 1.1$ equiv, $1.0 \mathrm{M}$ in PhMe). The crude reaction mixture was observed to be a ca. 20:1 $E: Z$ ratio of alkene isomers, as determined by ${ }^{1} \mathrm{H}$ NMR. The residue was purified by automated flash column chromatography on silica gel $\left(40 \mathrm{~g} \mathrm{SiO}_{2}\right.$, gradient elution: hexane to $20 \% \mathrm{EtOAc}$ in hexane) to yield SI-2t (562 mg, 53\% yield over two steps) as a yellow oil and a >20:1 ratio of $E: Z$ alkene isomers.

${ }^{1} \mathrm{H}$ NMR $\left(\mathrm{CDCl}_{3}, 500 \mathrm{MHz}\right): \delta 8.24(\mathrm{~s}, 2 \mathrm{H}), 6.35(\mathrm{~s}, 1 \mathrm{H}), 3.84-3.81(\mathrm{~m}, 4 \mathrm{H}), 3.77-3.73(\mathrm{~m}, 4 \mathrm{H})$, $2.26(\mathrm{~s}, 3 \mathrm{H})$.

${ }^{13} \mathrm{C} \mathrm{NMR}\left(\mathrm{CDCl}_{3}, 101 \mathrm{MHz}\right): \delta 160.8,157.5,147.1,118.7$ (q, J = 319.9 Hz), 117.2, 115.3, 66.9, 44.4, 18.1.

${ }^{19} \mathrm{~F} \mathrm{NMR}\left(\mathrm{CDCl}_{3}, 471 \mathrm{MHz}\right): \delta-73.80$.

IR (Diamond-ATR, neat) $\widetilde{v}_{\max }: 2964,2857,1598,1172,1203,610$.

Melting Point $\left({ }^{\circ} \mathrm{C}\right): 34-35$.

EA calcd. for $\mathrm{C}_{12} \mathrm{H}_{14} \mathrm{~F}_{3} \mathrm{~N}_{3} \mathrm{O}_{4} \mathrm{~S}$ : C, 40.79; $\mathrm{H}, 3$.99. Found: $\mathrm{C}, 40.52 ; \mathrm{H}, 3.92$.

(E)-1-(1-cyclopentyl-1H-pyrrolo[2,3-b]pyridin-5-yl)prop-1-en-2-yl trifluoromethanesulfonate (SI-2u)

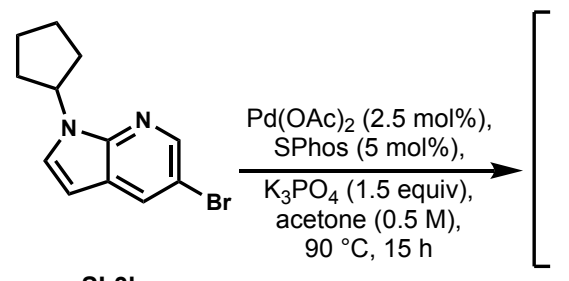

SI-3b

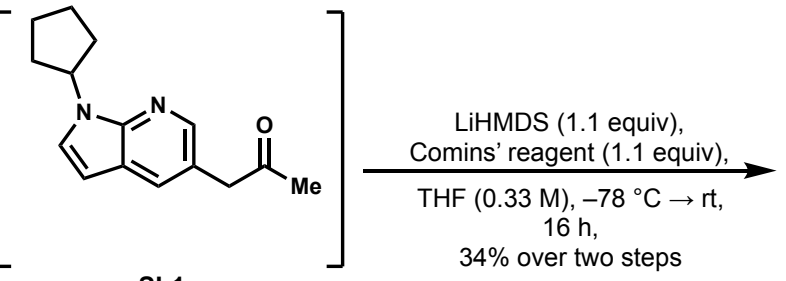

SI-1e

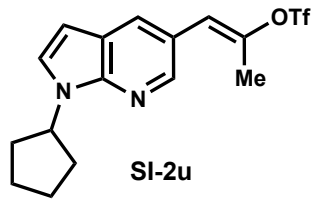

SI-1e was prepared according to General Procedure B, using 5-bromo-1-cyclopentyl-1Hpyrrolo[2,3-b]pyridine (SI-3b) (1.33 g, $5.00 \mathrm{mmol}, 1.0$ equiv), potassium phosphate monohydrate (1.15 g, $5.00 \mathrm{mmol}, 1.5$ equiv), Pd(OAc) 2 (28.1 mg, $125 \mu \mathrm{mol}, 2.5 \mathrm{~mol} \%)$, SPhos (103 mg, 250 
$\mu \mathrm{mol}, 5 \mathrm{~mol} \%)$ and acetone $(10 \mathrm{~mL}, 0.5 \mathrm{M})$. The crude residue was used in the subsequent step without further purification.

SI-2u was prepared according to General Procedure A using unpurified SI-1e (5.00 mmol, 1.0 equiv). Comins' reagent $(2.16 \mathrm{~g}, 5.50 \mathrm{mmol}, 1.1$ equiv), THF (16 mL, $0.33 \mathrm{M})$, and LiHMDS (5.5 $\mathrm{mL}, 5.5 \mathrm{mmol}, 1.1$ equiv, $1.0 \mathrm{M}$ in PhMe). The crude reaction mixture was observed to be a ca. $10: 1$ ratio of $E: Z$ alkene isomers, as determined by ${ }^{1} \mathrm{H}$ NMR. The residue was purified by automated flash column chromatography on silica gel $\left(40 \mathrm{~g} \mathrm{SiO}_{2}\right.$, gradient elution: hexane to $10 \% \mathrm{EtOAc}$ in hexane) to yield SI-2u as a yellow oil (641 $\mathrm{mg}, 34 \%$ yield over two steps) and a $>20: 1$ ratio of $E: Z$ alkene isomers.

${ }^{1} \mathrm{H}$ NMR $\left(\mathrm{CDCl}_{3}, 400 \mathrm{MHz}\right): \delta 8.21(\mathrm{~d}, J=2.1 \mathrm{~Hz}, 1 \mathrm{H}), 7.79(\mathrm{~d}, J=2.1 \mathrm{~Hz}, 1 \mathrm{H}), 7.34(\mathrm{~d}, J=3.5$ $\mathrm{Hz}, 1 \mathrm{H}), 6.72(\mathrm{~s}, 1 \mathrm{H}), 6.47(\mathrm{~d}, J=3.6 \mathrm{~Hz}, 1 \mathrm{H}), 5.28(\mathrm{p}, J=7.2 \mathrm{~Hz}, 1 \mathrm{H}), 2.31(\mathrm{~s}, 3 \mathrm{H}), 2.28-2.22(\mathrm{~m}$, $2 \mathrm{H}), 1.94-1.86(\mathrm{~m}, 4 \mathrm{H}), 1.82-1.76(\mathrm{~m}, 2 \mathrm{H})$.

${ }^{13} \mathrm{C}$ NMR $\left(\mathrm{CDCl}_{3}, 101 \mathrm{MHz}\right): \delta 147.5,147.2,143.1,128.6,126.3,121.1,120.6,118.7$ (q, J = 320.0 $\mathrm{Hz}), 115.7,100.0,55.2,33.0,24.2,17.9$.

${ }^{19} \mathrm{~F}$ NMR $\left(\mathrm{CDCl}_{3}, 471 \mathrm{MHz}\right): \delta-73.80$.

IR (Diamond-ATR, neat) $\widetilde{v}_{\text {max }}: 2961,2873,1600,1246,1140,889,787$.

HRMS (DART) m/z: [M+H] $]^{+}$calcd. for $\mathrm{C}_{16} \mathrm{H}_{18} \mathrm{~F}_{3} \mathrm{~N}_{2} \mathrm{O}_{3} \mathrm{~S}^{+}:$375.0985. Found: 375.0988 .

(E)-1-(furan-3-yl)prop-1-en-2-yl trifluoromethanesulfonate (SI-2v)

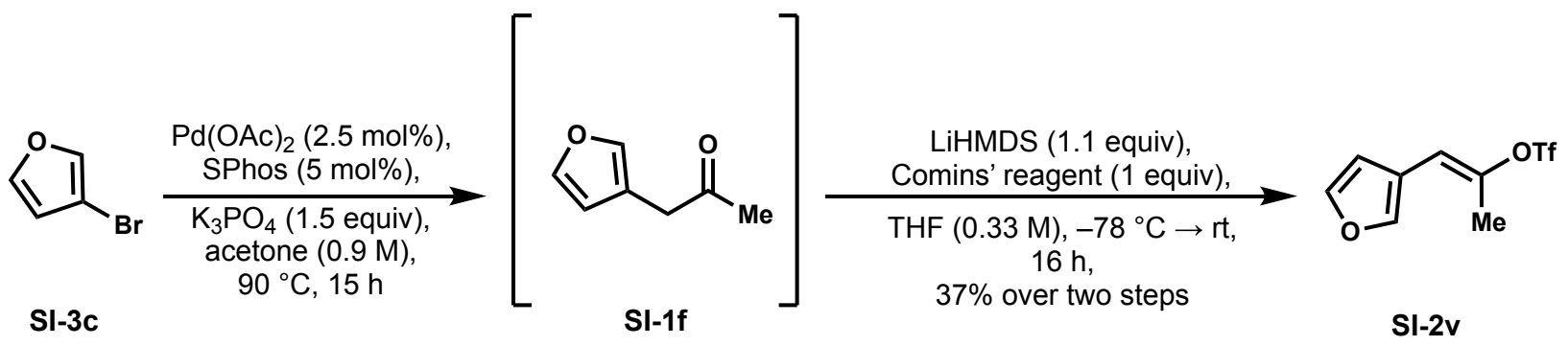

SI-1f was prepared according to General Procedure B, using 3-bromofuran (SI-3c) (1.90 g, 12.9 mmol, 1.0 equiv), potassium phosphate monohydrate $\left(2.98 \mathrm{~g}, 12.9 \mathrm{mmol}, 1.5\right.$ equiv), $\mathrm{Pd}(\mathrm{OAc})_{2}$ (73 mg, $0.32 \mathrm{mmol}, 2.5 \mathrm{~mol} \%$ ), SPhos (265 mg, $0.646 \mathrm{mmol}, 5 \mathrm{~mol} \%$ ) and acetone (15 mL, 0.9 $\mathrm{M})$. The crude residue was used in the subsequent step without further purification.

SI-2v was prepared according to General Procedure A using unpurified SI-1f (12.9 mmol, 1.0 equiv). Comins' reagent $(5.07 \mathrm{~g}, 12.9 \mathrm{mmol}, 1.0$ equiv), THF (40 mL, $0.33 \mathrm{M})$, and LiHMDS (14.2 $\mathrm{mL}, 14.2 \mathrm{mmol}, 1.1$ equiv, $1.0 \mathrm{M}$ in PhMe). The crude reaction mixture was observed to be a ca. $5: 1$ ratio of $E: Z$ alkene isomers, as determined by ${ }^{1} \mathrm{H}$ NMR. The residue was purified by automated flash column chromatography on silica gel (100 g SiO 2 , gradient elution: hexane to $5 \% \mathrm{CH}_{2} \mathrm{Cl}_{2}$ in hexane) to yield SI-2v (1.22 g, 37\% yield over two steps) as a dark brown oil and a 14:1 ratio of $E: Z$ alkene isomers.

${ }^{1} \mathrm{H}$ NMR $\left(\mathrm{CDCl}_{3}, 500 \mathrm{MHz}\right)$ : (major isomer, E-alkene) $\delta 7.48(\mathrm{~s}, 1 \mathrm{H}), 7.45(\mathrm{t}, J=1.7 \mathrm{~Hz}, 1 \mathrm{H}), 6.44$ (d, $J=1.8 \mathrm{~Hz}, 1 \mathrm{H}), 6.37(\mathrm{~s}, 1 \mathrm{H}), 2.28(\mathrm{~s}, 3 \mathrm{H})$.

${ }^{13} \mathrm{C}$ NMR $\left(\mathrm{CDCl}_{3}, 126 \mathrm{MHz}\right)$ : (major isomer, E-alkene) $\delta 146.9,143.9,142.2,118.7$ (q, $\mathrm{J}=320.1$ $\mathrm{Hz})$ 118.0, 113.5, 109.9, 18.2.

${ }^{19} \mathrm{~F}$ NMR $\left(\mathrm{CDCl}_{3}, 471 \mathrm{MHz}\right)$ : (major isomer) $\delta-73.89$

IR (Diamond-ATR, neat) $\widetilde{\boldsymbol{v}}_{\max }: 2964,1414,1202,1139,890$. 
HRMS (DART) m/z: [M+H] $]^{+}$calcd. for $\mathrm{C}_{8} \mathrm{H}_{8} \mathrm{~F}_{3} \mathrm{O}_{4} \mathrm{~S}^{+}: 257.0090$. Found: 257.0097.

\section{6,7-dimethoxy-3,4-dihydronaphthalen-1-yl trifluoromethanesulfonate (SI-2w)}<smiles>COc1cc2c(cc1OC)C(=O)CCC2</smiles>

SI-1g

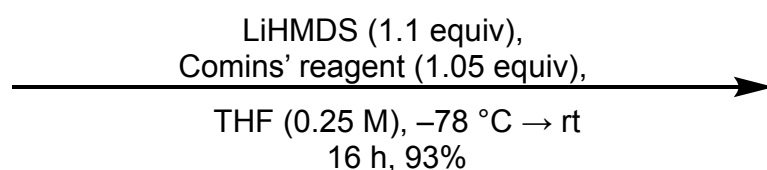

$16 \mathrm{~h}, 93 \%$<smiles>COc1cc2c(cc1OC)C(Br)=CCC2</smiles>

SI-2w

Prepared according to General Procedure A using 6,7-dimethoxy-3,4-dihydronaphthalen-1(2H)one SI-1g (1.24 g, $6.01 \mathrm{mmol}, 1.0$ equiv), Comins' reagent (2.48 g, $6.60 \mathrm{mmol}, 1.05$ equiv), THF $(25 \mathrm{~mL}, 0.25 \mathrm{M})$ and LiHMDS $(7.2 \mathrm{~mL}, 7.2 \mathrm{mmol}, 1.1$ equiv, $1.0 \mathrm{M}$ in PhMe). The residue was purified by flash column chromatography on silica gel ( $9 \%$ acetone in hexane) to yield $\mathbf{S I - 2 w}$ (1.9 $\mathrm{g}, 93 \%$ yield) as an off-white solid.

${ }^{1} \mathrm{H}$ NMR $\left(\mathrm{CDCl}_{3}, 400 \mathrm{MHz}\right): \delta 6.88(\mathrm{~s}, 1 \mathrm{H}), 6.71(\mathrm{~s}, 1 \mathrm{H}), 5.89(\mathrm{t}, \mathrm{J}=4.8 \mathrm{~Hz}, 1 \mathrm{H}), 3.89(\mathrm{~s}, 3 \mathrm{H}), 3.88$ (s, 3H), $2.80(\mathrm{t}, J=8.3 \mathrm{~Hz}, 2 \mathrm{H}), 2.51-2.46(\mathrm{~m}, 2 \mathrm{H})$.

${ }^{13} \mathrm{C}$ NMR $\left(\mathrm{CDCl}_{3}, 101 \mathrm{MHz}\right): \delta 149.6,147.8,146.3,129.4,121.3,118.8$ (q, J = 320.6), 115.2, 111.5, 105.3, 56.2, 56.2, 26.8, 22.7.

${ }^{19} \mathrm{~F}$ NMR $\left(\mathrm{CDCl}_{3}, 376 \mathrm{MHz}\right): \delta-73.75$.

IR (Diamond-ATR, neat) $\widetilde{\boldsymbol{v}}_{\max }: 2938,2837,1516,1417,1124,958$.

Melting Point $\left({ }^{\circ} \mathrm{C}\right): 48-50$.

EA calcd. for $\mathrm{C}_{13} \mathrm{H}_{13} \mathrm{~F}_{3} \mathrm{O}_{5} \mathrm{~S}$ : C, 46.16; $\mathrm{H}, 3.87$. Found: $\mathrm{C}, 45.90 ; \mathrm{H}, 3.75$. 


\subsection{Synthesis and Characterization of Vinyl Arenes and Terminal Olefins}

\section{The following alkenes were prepared according to known protocols:}<smiles>C=Cc1ccc2occc2c1</smiles>

SI-5a ref. 12<smiles>C=Cc1ccc2c(c1)CCc1cccnc1C2=C1CCN(C(C)=O)CC1</smiles>

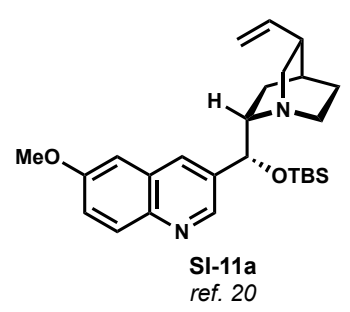<smiles>C=Cc1ccc(OC)c(Cl)c1</smiles>

SI-5b
ref. 13<smiles>C=Cc1ccc([N+](=O)[O-])cc1</smiles>

SI-5c
ref. 14<smiles>C=Cc1ccc2c(c1)c1ccccc1n2P</smiles>

SI-5d
ref. 15
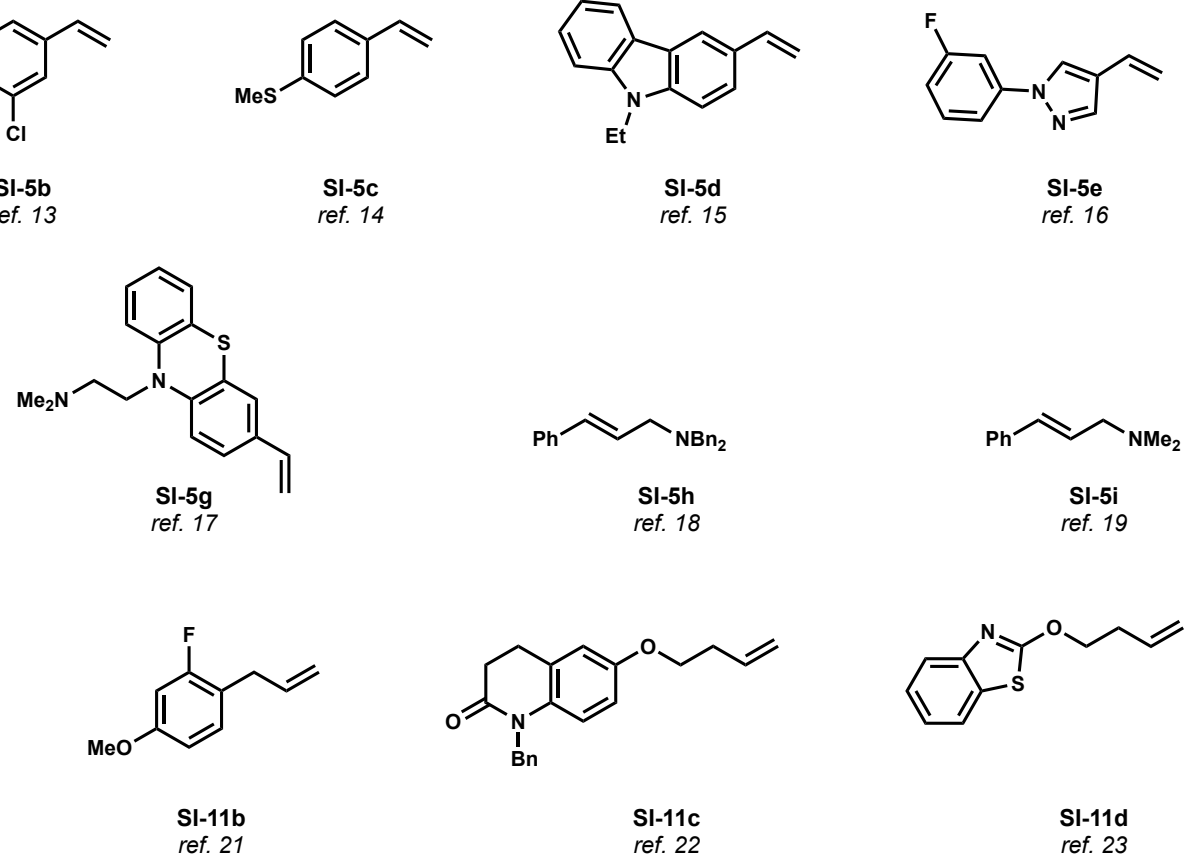

1-(3-vinylphenyl)thiomorpholine (SI-5j)<smiles>C=Cc1cccc(Br)c1</smiles>

SI-3d
$\mathrm{Pd}(\mathrm{OAc})_{2}(5 \mathrm{~mol} \%)$, RuPhos (10 mol\%), $t$-BuONa ( 1.5 equiv), thiomorpholine (1.2 equiv), THF $(0.5 \mathrm{M}), 90^{\circ} \mathrm{C}, 18 \mathrm{~h}, 89 \%$<smiles>C=Cc1cccc(N2CCSCC2)c1</smiles>

SI-5j

Inside a nitrogen-filled glovebox, an oven-dried reaction tube (Fisherbrand, 20x150 mm, $1495937 \mathrm{C}$ ) equipped with a magnetic stir bar was charged with $\mathrm{Pd}(\mathrm{OAc})_{2}(34 \mathrm{mg}, 0.15 \mathrm{mmol}, 5.0$ mol\%), RuPhos (140 mg, $0.30 \mathrm{mmol}, 10 \mathrm{~mol} \%$ ) and THF (6 mL, $0.5 \mathrm{M}$ ).

After the reaction mixture had stirred at room temperature for $15 \mathrm{~min}$, thiomorpholine (362 $\mu \mathrm{L}, 3.60 \mathrm{mmol}, 1.2$ equiv), sodium tert-butoxide (433 mg, $4.50 \mathrm{mmol}, 1.5$ equiv) and 1-bromo-3vinylbenzene SI-3d (392 $\mu \mathrm{L}, 3.00 \mathrm{mmol}, 1.0$ equiv) were added sequentially to the palladiumcatalyst solution. The reaction tube was sealed with a screw cap containing a PTFE septum, taken outside the glovebox, and the reaction vessel was placed in an oil bath preheated to $80^{\circ} \mathrm{C}$. After the reaction mixture had stirred at $80^{\circ} \mathrm{C}$ for $18 \mathrm{~h}$, the reaction vessel was removed from the oil bath and the reaction mixture was allowed cool to room temperature. Once at room temperature, the reaction mixture was filtered through a $2 \mathrm{~cm}$ pad of $\mathrm{SiO}_{2}$ using a glass fritted funnel. The reaction tube was subsequently rinsed with ca. $15 \mathrm{~mL}$ of EtOAc and filtered through the same pad of $\mathrm{SiO}_{2}$. The volatiles were carefully concentrated in vacuo with the aid of a rotary evaporator. The residue was purified by flash column chromatography on silica gel ( $2.5 \%$ in EtOAc in pentane) to yield SI-5j (550 mg, 89\% yield) as a yellow oil.

${ }^{1} \mathrm{H}$ NMR $\left(\mathrm{CDCl}_{3}, 500 \mathrm{MHz}\right): \delta 7.23(\mathrm{t}, \mathrm{J}=7.8 \mathrm{~Hz}, 1 \mathrm{H}), 6.98-6.90(\mathrm{~m}, 2 \mathrm{H}), 6.85-6.78(\mathrm{~m}, 1 \mathrm{H}), 6.68$ (dd, $J=17.6,10.9 \mathrm{~Hz}, 1 \mathrm{H}), 5.72(\mathrm{~d}, J=17.5 \mathrm{~Hz}, 1 \mathrm{H}), 5.23(\mathrm{~d}, J=10.9 \mathrm{~Hz}, 1 \mathrm{H}), 3.55(\mathrm{dd}, J=5.1$, $5.1 \mathrm{~Hz}, 4 \mathrm{H}), 2.80-2.72(\mathrm{~m}, 4 \mathrm{H})$.

${ }^{13} \mathrm{C}$ NMR $\left(\mathrm{CDCl}_{3}, 126 \mathrm{MHz}\right): \delta 151.8,138.8,137.3,129.5,118.1,117.0,115.4,114.0,52.4,27.0$. 
IR (Diamond-ATR, neat) $\widetilde{\boldsymbol{v}}_{\text {max }}: 2907,2817,1594,1450,1286,909,787$.

HRMS (DART) m/z: [M+H] $]^{+}$calcd. for $\mathrm{C}_{12} \mathrm{H}_{16} \mathrm{NS}^{+}:$206.0098. Found: 206.0098 .

n-butyl 3-vinylbenzoate (SI-5k)<smiles>CCCCOC(=O)c1cccc(Br)c1</smiles>

SI-3e
$\mathrm{Pd}(\mathrm{OAc})_{2}(5 \mathrm{~mol} \%)$, SPhos $(10 \mathrm{~mol} \%)$,
$\underset{\mathrm{K}_{2} \mathrm{CO}_{3} \mathrm{~K}\left(1.5 \text { equiv), 1,4-dioxane } / \mathrm{H}_{2} \mathrm{O}(5: 1,0.4 \mathrm{M}),\right.}{\stackrel{\mathrm{m} \text { equiv), } 90^{\circ} \mathrm{C}, 18 \mathrm{~h}, 84 \%}{\longrightarrow}}$<smiles>C=Cc1cccc(C(=O)OCCCC)c1</smiles>

SI-5k

To a reaction tube (Fisherbrand, 20x150 mm, 1495937C) equipped with a magnetic stir bar was charged $\mathrm{Pd}(\mathrm{OAc})_{2}$ (34 mg, $0.15 \mathrm{mmol}, 5.0 \mathrm{~mol} \%$ ), SPhos (12 mg, $0.30 \mathrm{mmol}, 10.0 \mathrm{~mol} \%$ ), $\mathrm{K}_{2} \mathrm{CO}_{3}(1.24 \mathrm{~g}, 9.00 \mathrm{mmol}, 3.0$ equiv), potassium vinyltrifluoroborate $(804 \mathrm{mg}, 6.00 \mathrm{mmol}, 2.0$ equiv), and butyl 3-bromobenzoate SI-3e (770 mg, $3.0 \mathrm{mmol}, 1.0$ equiv). The reaction tube was sealed with a screw cap containing a PTFE septum and then attached by rubber hose via a needle to a dual manifold Schlenk line. The tube was then evacuated/backfilled with $\mathrm{N}_{2}$ (this process was repeated a total of three times). The reaction mixture was diluted with 1,4-dioxane $(7.5 \mathrm{~mL})$ and $\mathrm{H}_{2} \mathrm{O}(1.5 \mathrm{~mL})$ via syringe by puncturing the septum, to achieve a final reaction concentration of 0.4 $\mathrm{M}$, and the reaction vessel was moved to an oil bath preheated to $90^{\circ} \mathrm{C}$.

After the reaction mixture had stirred at $90^{\circ} \mathrm{C}$ for $18 \mathrm{~h}$, the reaction vessel was removed from the oil bath, and the reaction mixture was allowed to cool to room temperature. Once at room temperature, the reaction mixture was diluted with $\mathrm{Et}_{2} \mathrm{O}(5 \mathrm{~mL})$ and $\mathrm{H}_{2} \mathrm{O}(5 \mathrm{~mL})$, then transferred to a separatory funnel. The layers were separated and the aqueous phase was extracted with $\mathrm{Et}_{2} \mathrm{O}$ $(3 \times 15 \mathrm{~mL})$. The combined organic phases were washed with brine $(50 \mathrm{~mL})$, dried with $\mathrm{MgSO}_{4}$ and the volatiles were carefully concentrated in vacuo with the aid of a rotary evaporator. The residue was purified by flash column chromatography on silica gel ( $3 \%$ pentane in EtOAc) to yield SI-5k (516 mg, 84\% yield) as a pale-yellow oil.

${ }^{1} \mathrm{H}$ NMR $\left(\mathrm{CDCl}_{3}, 400 \mathrm{MHz}\right): \delta 8.07(\mathrm{~s}, 1 \mathrm{H}), 7.93(\mathrm{~d}, J=7.7 \mathrm{~Hz}, 1 \mathrm{H}), 7.59(\mathrm{~d}, J=7.7 \mathrm{~Hz}, 1 \mathrm{H}), 7.40$ $(\mathrm{t}, J=7.7 \mathrm{~Hz}, 1 \mathrm{H}), 6.76(\mathrm{dd}, J=17.6,10.9 \mathrm{~Hz}, 1 \mathrm{H}), 5.83(\mathrm{~d}, J=17.6 \mathrm{~Hz}, 1 \mathrm{H}), 5.32(\mathrm{~d}, J=10.9 \mathrm{~Hz}$, $1 \mathrm{H}), 4.34$ (t, $J=6.7 \mathrm{~Hz}, 2 \mathrm{H}$ ), 1.77 (qt, $J=7.4 \mathrm{~Hz}, 2 \mathrm{H}), 1.49$ (h, J = 7.4 Hz, 2H), 0.99 (t, J = 7.4 Hz, $3 \mathrm{H})$.

${ }^{13} \mathrm{C}$ NMR $\left(\mathrm{CDCl}_{3}, 101 \mathrm{MHz}\right): \delta 166.7,138.0,136.1,131.0,130.5,128.9,128.7,127.5,115.2,65.1$, 30.9, 19.4, 13.9.

IR (Diamond-ATR, neat) $\widetilde{\boldsymbol{v}}_{\max }: 2958,1716,1440,1278,1261,1085,908$.

EA calcd. for $\mathrm{C}_{13} \mathrm{H}_{16} \mathrm{O}_{2}$ : C, 76.44; $\mathrm{H}, 7.90$. Found: $\mathrm{C}, 76.29 ; \mathrm{H}, 8.07$.

\section{1-(4-vinylphenyl)-1H-pyrrole (SI-5I)}
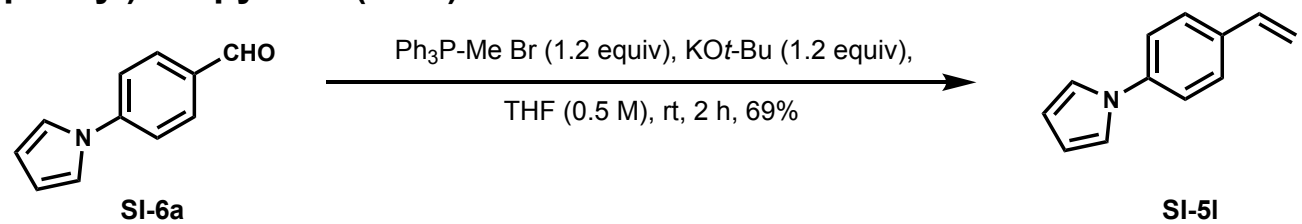

To an oven-dried $100 \mathrm{~mL}$ round-bottom flask equipped with a magnetic stir bar was added methyltriphenylphosphonium bromide $(4.29 \mathrm{~g}, 12.0 \mathrm{mmol}, 1.2$ equiv) and the reaction flask was sealed with a rubber septum, attached by rubber hose via a needle to a dual manifold Schlenk line, and placed under $\mathrm{N}_{2}$ atmosphere. Following this, THF $(20 \mathrm{~mL}, 0.5 \mathrm{M})$ was added via syringe by puncturing the rubber septum. The rubber septum was removed, and to the stirred reaction mixture was added potassium tert-butoxide (1.35 g, $12.0 \mathrm{mmol}, 1.2$ equiv) at room temperature, and the flask was resealed with the rubber septum. After the reaction mixture had stirred at room temperature for $1 \mathrm{~h}$, the rubber septum was removed, 4-(1H-pyrrol-1-yl)benzaldehyde SI-6a (1.71 $\mathrm{g}, 10.0 \mathrm{mmol}, 1.0$ equiv) was added to the reaction mixture, and the flask was resealed with the rubber septum. 
After the resulting reaction mixture had stirred at room temperature for an additional $1 \mathrm{~h}$, the reaction mixture was diluted with sat. aq. $\mathrm{NH}_{4} \mathrm{Cl}(20 \mathrm{~mL})$ and transferred to a separatory funnel. The layers were separated and the aqueous layer was extracted with EtOAc $(3 \times 20 \mathrm{~mL})$. The combined organic layers were washed with brine $(15 \mathrm{~mL})$, dried over $\mathrm{Na}_{2} \mathrm{SO}_{4}$, filtered and concentrated in vacuo with the aid of a rotary evaporator. Purification by automated flash column chromatography (50 $\mathrm{g} \mathrm{SiO}_{2}$, gradient elution: hexane to $25 \%$ EtOAc in hexane) afforded SI-5I (1.16 $\mathrm{g}, 69 \%)$ as a colorless solid.

${ }^{1} \mathrm{H} \mathrm{NMR}\left(\mathrm{CDCl}_{3}, 400 \mathrm{MHz}\right): 7.46(\mathrm{~d}, J=8.5 \mathrm{~Hz}, 2 \mathrm{H}), 7.36(\mathrm{~d}, J=8.5 \mathrm{~Hz}, 2 \mathrm{H}), 7.10$ (dd, $J=2.1,2.1$ $\mathrm{Hz}, 2 \mathrm{H}), 6.73$ (dd, $J=17.6,10.9 \mathrm{~Hz}, 1 \mathrm{H}), 6.35$ (dd, $J=2.2,2.2 \mathrm{~Hz}, 2 \mathrm{H}), 5.74(\mathrm{~d}, J=17.6 \mathrm{~Hz}, 1 \mathrm{H})$, $5.26(\mathrm{~d}, J=10.8 \mathrm{~Hz}, 1 \mathrm{H})$.

${ }^{13} \mathrm{C}$ NMR $\left(\mathrm{CDCl}_{3}, 101 \mathrm{MHz}\right): 140.3,136.0,135.2,127.5,120.5,119.3,113.9,110.6$.

IR (Diamond-ATR, neat) $\widetilde{v}_{\text {max: }}$ 3051, 1609, 1520, 1330, 1264, 990, 842.

Melting Point $\left({ }^{\circ} \mathrm{C}\right): 127-128$.

EA calcd. for $\mathrm{C}_{12} \mathrm{H}_{11} \mathrm{~N}$ : C, 85.17; $\mathrm{H}, 6.55$ Found: $\mathrm{C}, 85.09 ; \mathrm{H}, 6.57$.

(E)-5-(3-(benzyloxy)prop-1-en-1-yl)-2-methoxypyridine (SI-5m)
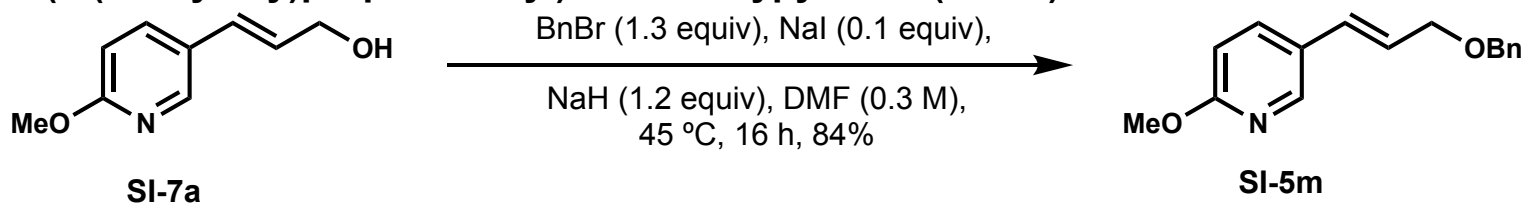

To an oven-dried reaction tube (Fisherbrand, 20x150 mm, 1495937C) equipped with a magnetic stir bar was added sodium hydride $(94.4 \mathrm{mg}, 3.53 \mathrm{mmol}, 1.2$ equiv, $90 \%)$ and DMF $(6.0$ $\mathrm{mL}, 0.7 \mathrm{M}$ ). The tube was sealed with a PTFE screw cap, attached by rubber hose via a needle to a dual manifold Schlenk line, and placed under $\mathrm{N}_{2}$ atmosphere. To the stirred reaction mixture was added a solution (via syringe by puncturing the PTFE septum) of (E)-3-(6-methoxypyridin-3yl)prop-2-en-1-ol (Sl-7a) (0.50 g, $3.0 \mathrm{mmol}, 1.0$ equiv) in DMF (4.0 mL, $0.75 \mathrm{M})$ dropwise over 5 min at room temperature (CAUTION! gas evolution), to achieve a final reaction concentration of $0.3 \mathrm{M}$. After the reaction mixture had stirred at room temperature for $10 \mathrm{~min}$, the septum was removed and benzyl bromide $(0.46 \mathrm{~mL}, 3.9 \mathrm{mmol}, 1.3$ equiv) and sodium iodide $(45 \mathrm{mg}, 0.30$ $\mathrm{mmol}, 0.1$ equiv) were added sequentially to the reaction mixture. The flask was resealed with the septum and the reaction vessel was transferred to an oil bath preheated to $45^{\circ} \mathrm{C}$.

After the reaction mixture had stirred at $45^{\circ} \mathrm{C}$ for $16 \mathrm{~h}$, the reaction vessel was removed from the oil bath. Once at room temperature, sat. aq. $\mathrm{NH}_{4} \mathrm{Cl}(10 \mathrm{~mL})$ and EtOAc $(5 \mathrm{~mL})$ was added to the reaction mixture. The layers were separated and the aqueous layer was extracted with EtOAc $(3 \times 10 \mathrm{~mL})$. The combined organic layers were washed with brine $(2 \times 10 \mathrm{~mL})$, dried over $\mathrm{Na}_{2} \mathrm{SO}_{4}$, filtered and concentrated in vacuo with the aid of a rotary evaporator. Purification by automated flash column chromatography $\left(50 \mathrm{~g} \mathrm{SiO}_{2}\right.$, gradient elution: hexane to $60 \%$ EtOAc in hexane) afforded SI-5m as a yellow oil (647 mg, 84\%).

${ }^{1} \mathrm{H}$ NMR $\left(\mathrm{CDCl}_{3}, 400 \mathrm{MHz}\right): \delta 8.11(\mathrm{~d}, J=2.4 \mathrm{~Hz}, 1 \mathrm{H}), 7.67(\mathrm{dd}, J=8.7,2.4 \mathrm{~Hz}, 1 \mathrm{H}), 7.40-7.27$ $(\mathrm{m}, 5 \mathrm{H}), 6.71(\mathrm{~d}, J=8.7 \mathrm{~Hz}, 1 \mathrm{H}), 6.57(\mathrm{~d}, J=16.0 \mathrm{~Hz}, 1 \mathrm{H}), 6.22(\mathrm{dt}, J=16.0,6.0 \mathrm{~Hz}, 1 \mathrm{H}), 4.58(\mathrm{~s}$, $2 \mathrm{H}), 4.18(\mathrm{~d}, J=6.0 \mathrm{~Hz}, 2 \mathrm{H}), 3.94(\mathrm{~s}, 3 \mathrm{H})$.

${ }^{13} \mathrm{C}$ NMR $\left(\mathrm{CDCl}_{3}, 101 \mathrm{MHz}\right): \delta$ 163.8, 145.7, 138.3, 135.8, 128.8, 128.6, 128.0, 127.8, 127.1, 126.1, 125.5, 72.5, 70.9, 53.6.

IR (Diamond-ATR, neat) $\widetilde{v}_{\text {max }}: 2945,1716,1601,1492,1287,1116,832,698$.

HRMS (DART) m/z: [M+H] $]^{+}$calcd. for $\mathrm{C}_{16} \mathrm{H}_{18} \mathrm{NO}^{+}:$256.1332. Found: 256.1337. 
Supporting Information

(E)-2-((4-phenylbut-3-en-1-yl)oxy)benzo[d]thiazole (SI-5n)

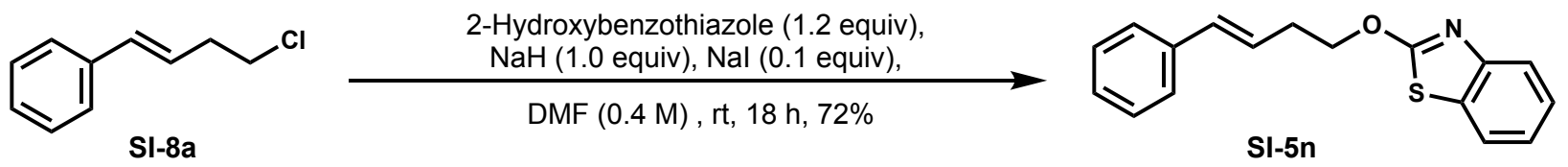

To an oven-dried reaction tube (Fisherbrand, 20x150 mm, 1495937C) equipped with a magnetic stir bar was added sodium hydride (82 $\mathrm{mg}, 3.1 \mathrm{mmol}, 1.0$ equiv, $90 \%)$, sodium iodide (47 mg, $0.31 \mathrm{mmol}, 0.1$ equiv) and DMF (1 mL, 3.4 M). The tube was sealed with a PTFE screw cap, attached by rubber hose via a needle to a dual manifold Schlenk line, placed under $\mathrm{N}_{2}$ atmosphere, and the reaction vessel was transferred to a $0{ }^{\circ} \mathrm{C}$ ice-water bath. To the stirred reaction mixture was added a solution (via syringe by puncturing the PTFE septum) of 2hydroxybenzothiazole (566 mg, $3.74 \mathrm{mmol}, 1.2$ equiv) in DMF (5 mL, $0.75 \mathrm{M})$ dropwise over $5 \mathrm{~min}$ (CAUTION! gas evolution). After the reaction mixture had stirred for $10 \mathrm{~min}$, a solution of $(E)-(4-$ chlorobut-1-en-1-yl)benzene SI-8a (520 mg, $3.1 \mathrm{mmol}, 1.0$ equiv) in DMF (3.0 mL, $1.0 \mathrm{M})$ was added dropwise over 2 min via syringe by puncturing the PTFE septum. The final reaction concentration was $0.4 \mathrm{M}$. The ice-water bath was removed and the reaction was allowed to stir at room temperature.

After the reaction had stirred at room temperature for $18 \mathrm{~h}$, the reaction mixture was diluted with sat. aq. $\mathrm{NH}_{4} \mathrm{Cl}(5 \mathrm{~mL})$ and $\mathrm{EtOAc}(7 \mathrm{~mL})$. The layers were separated and the aqueous layer was extracted with EtOAc $(3 \times 10 \mathrm{~mL})$. The combined organic layers were washed with brine $(2 \mathrm{x}$ $10 \mathrm{~mL}$ ), dried over $\mathrm{Na}_{2} \mathrm{SO}_{4}$, filtered and concentrated in vacuo with the aid of a rotary evaporator. Purification by automated flash column chromatography $\left(50 \mathrm{~g} \mathrm{SiO}_{2}\right.$, gradient elution: hexane to $10 \%$ EtOAc in hexane) afforded SI-5n as a colorless solid (628 mg, 72\%).

${ }^{1} \mathrm{H}$ NMR $\left(\mathrm{CDCl}_{3}, 400 \mathrm{MHz}\right): \delta 7.43(\mathrm{dd}, J=7.7,1.2 \mathrm{~Hz}, 1 \mathrm{H}), 7.33(\mathrm{td}, J=7.8,1.3 \mathrm{~Hz}, 1 \mathrm{H}), 7.31-$ $7.27(\mathrm{~m}, 4 \mathrm{H}), 7.25-7.19(\mathrm{~m}, 1 \mathrm{H}), 7.17(\mathrm{td}, J=7.7,1.1 \mathrm{~Hz}, 1 \mathrm{H}), 7.09(\mathrm{~d}, J=8.1 \mathrm{~Hz}, 1 \mathrm{H}), 6.45(\mathrm{dt}$, $J=15.7,1.4 \mathrm{~Hz}, 1 \mathrm{H}), 6.19(\mathrm{dt}, J=15.7,7.1 \mathrm{~Hz}, 1 \mathrm{H}), 4.09(\mathrm{dd}, J=7.3,7.3 \mathrm{~Hz}, 2 \mathrm{H}), 2.66(q d, J=$ 7.3, $1.4 \mathrm{~Hz}, 2 \mathrm{H})$.

${ }^{13} \mathrm{C}$ NMR $\left(\mathrm{CDCl}_{3}, 101 \mathrm{MHz}\right): \delta$ 170.0, 137.2, 137.1, 133.1, 128.7, 127.5, 126.4, 126.3, 125.6, 123.2, 123.0, 122.9, 110.7, 42.6, 31.5.

IR (Diamond-ATR, neat) $\widetilde{v}_{\text {max }}: 3019,2936,1674,1594,1471,1322,1166,961$.

Melting Point $\left({ }^{\circ} \mathrm{C}\right): 103-104$.

HRMS (DART) m/z: [M+H] ${ }^{+}$calcd. for $\mathrm{C}_{17} \mathrm{H}_{16} \mathrm{NOS}^{+}:$282.0947. Found: 282.0949.

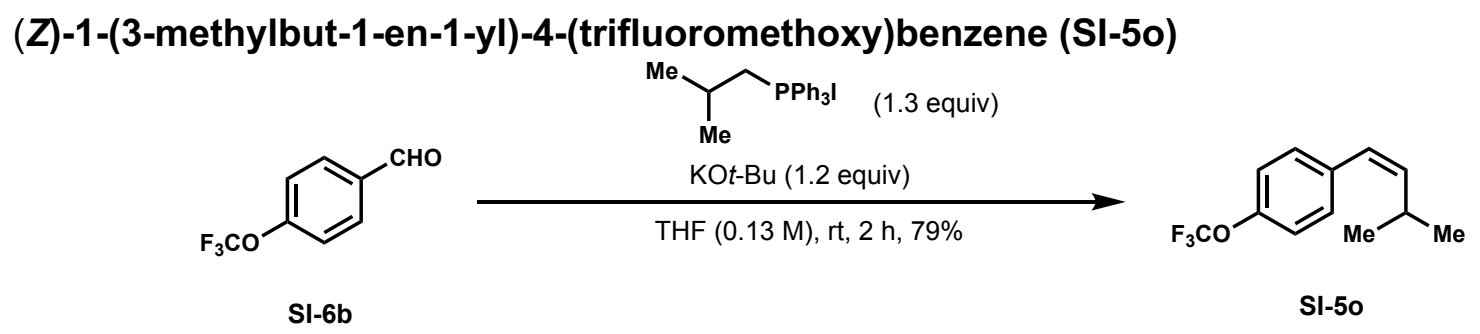

To an oven-dried $100 \mathrm{~mL}$ round-bottom flask equipped with a magnetic stir bar was added isobutyltriphenylphosphonium iodide $(4.10 \mathrm{~g}, 8.55 \mathrm{mmol}, 1.3$ equiv) and the reaction flask was sealed with a rubber septum, and attached by rubber hose via a needle to a dual manifold Schlenk line. The reaction vessel was evacuated/backfilled with $\mathrm{N}_{2}$ (this process was repeated a total of three times). Following this, THF $(50 \mathrm{~mL}, 0.13 \mathrm{M})$ was added via syringe by puncturing the rubber septum. The rubber septum was removed and to the stirred reaction mixture was added potassium tert-butoxide (855 mg, $7.89 \mathrm{mmol}, 1.2$ equiv) at room temperature. The reaction vessel was resealed with the rubber septum. After the reaction mixture had stirred at room temperature for 30 
min, 4-(trifluoromethoxy)benzaldehyde SI-6b (1.25 g, $6.57 \mathrm{mmol}, 1.0$ equiv) was added to the reaction mixture via syringe by puncturing the rubber septum.

After the resulting reaction mixture had stirred at room temperature for an additional $1 \mathrm{~h}$, the rubber septum was removed and the reaction mixture was diluted with sat. aq. $\mathrm{NH}_{4} \mathrm{Cl}(100$ $\mathrm{mL})$. The layers were separated and the aqueous layer was extracted with $\mathrm{Et}_{2} \mathrm{O}(3 \times 40 \mathrm{~mL})$. The combined organic layers were washed with brine $(20 \mathrm{~mL})$, dried over $\mathrm{Na}_{2} \mathrm{SO}_{4}$, filtered and concentrated in vacuo with the aid of a rotary evaporator to yield a crude yellow oil as a $1: 7 \mathrm{E:Z}$ ratio, as observed by ${ }^{1} \mathrm{H}$ NMR. Purification by automated flash column chromatography $\left(50 \mathrm{~g} \mathrm{SiO}_{2}\right.$, gradient elution: pentane to $10 \% \mathrm{Et}_{2} \mathrm{O}$ in pentane) afforded $\mathbf{S I - 5 o}(1.20 \mathrm{~g}, 79 \%)$ as a colorless oil and a 1:7 E:Z mixture of alkene isomers.

${ }^{1} \mathrm{H}$ NMR $\left(\mathrm{CDCl}_{3}, 400 \mathrm{MHz}\right)$ : (major isomer) $\delta 7.27$ (d, $\left.J=8.4 \mathrm{~Hz}, 2 \mathrm{H}\right), 7.17(\mathrm{~d}, \mathrm{~J}=8.3 \mathrm{~Hz}, 2 \mathrm{H})$, $6.27(\mathrm{~d}, J=11.6 \mathrm{~Hz}, 1 \mathrm{H}), 5.51(\mathrm{dd}, J=11.6,10.2 \mathrm{~Hz}, 1 \mathrm{H}), 2.89-2.79(\mathrm{~m}, 1 \mathrm{H}), 1.05(\mathrm{~s}, 3 \mathrm{H}), 1.04$ $(\mathrm{s}, 3 \mathrm{H})$.

${ }^{13} \mathrm{C} \mathrm{NMR}\left(\mathrm{CDCl}_{3}, 126 \mathrm{MHz}\right)$ : (major isomer) $\delta 141.4,136.7,130.0,127.2,125.2,120.8,120.7$ (q, $J=257.6 \mathrm{~Hz}), 27.3,23.2$.

${ }^{19} \mathrm{~F}$ NMR $\left(\mathrm{CDCl}_{3}, 471 \mathrm{MHz}\right): \delta-57.86$.

IR (Diamond-ATR, neat) $\widetilde{v}_{\text {max }}: 2963,1505,1255,1157,868,842$.

HRMS (DART) m/z: [M+H] calcd. for $\mathrm{C}_{12} \mathrm{H}_{14} \mathrm{~F}_{3} \mathrm{O}^{+}:$231.0991. Found: 231.0992.

\section{3-(4-vinylphenyl)quinoline (SI-5p)}

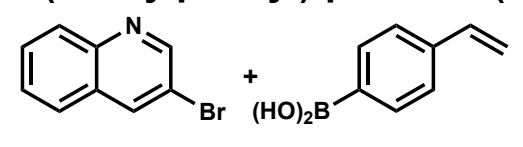

SI-3f

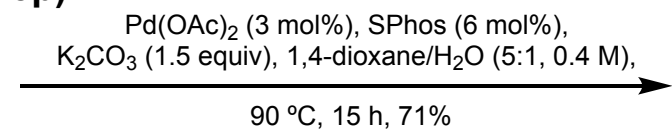

$90{ }^{\circ} \mathrm{C}, 15 \mathrm{~h}, 71 \%$

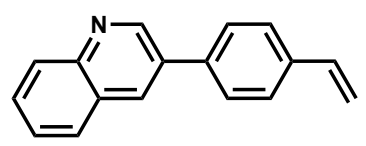

SI-5p

To an oven-dried $100 \mathrm{~mL}$ round-bottom flask equipped with a magnetic stir bar was charged $\mathrm{Pd}(\mathrm{OAc})_{2}$ (67 mg, $0.30 \mathrm{mmol}, 3.0 \mathrm{~mol} \%$ ), SPhos (246 mg, $\left.0.60 \mathrm{mmol}, 6.0 \mathrm{~mol} \%\right), \mathrm{K}_{2} \mathrm{CO}_{3}(2.07 \mathrm{~g}$, $15.0 \mathrm{mmol}, 1.5$ equiv), (4-vinylphenyl)boronic acid (SI-9a) (1.78, $12.0 \mathrm{mmol}, 1.2$ equiv) and 3bromoquinoline (SI-3f) (2.08 g, $10.0 \mathrm{mmol}, 1.0$ equiv). The round-bottom flask was sealed with a rubber septum and attached by rubber hose via a needle to a dual manifold Schlenk line. The flask was evacuated and backfilled with $\mathrm{N}_{2}$ (this process was repeated a total of three times). The reaction mixture was diluted with 1,4-dioxane $(15 \mathrm{~mL})$ and $\mathrm{H}_{2} \mathrm{O}(3 \mathrm{~mL})$ via syringe by puncturing the rubber septum, to achieve a final reaction concentration of $0.4 \mathrm{M}$. The rubber septum was removed and the reaction vessel was fitted with an oven-dried reflux condenser equipped with a septum attached by rubber hose via a needle to a dual manifold Schlenk line under an $\mathrm{N}_{2}$ atmosphere. The reaction vessel was then moved to an oil bath preheated to $90^{\circ} \mathrm{C}$.

After the reaction mixture had stirred at $90^{\circ} \mathrm{C}$ for $15 \mathrm{~h}$, the reaction vessel was removed from the oil bath, and the reaction mixture was allowed to cool to room temperature. Once at room temperature, the reaction mixture was diluted with EtOAc $(15 \mathrm{~mL})$ and $\mathrm{H}_{2} \mathrm{O}(30 \mathrm{~mL})$. The layers were separated and the aqueous phase was extracted with EtOAc $(3 \times 15 \mathrm{~mL})$. The combined organic phases were washed with brine $(50 \mathrm{~mL})$, dried with $\mathrm{Na}_{2} \mathrm{SO}_{4}$, filtered through a $5 \mathrm{~cm}$ pad of Celite using a glass fritted funnel, and the volatiles were concentrated in vacuo by rotary evaporation. The residue was purified by automated flash column chromatography on silica gel (100 $\mathrm{g} \mathrm{SiO}_{2}$, gradient elution: hexane to $65 \%$ EtOAc in hexane) to yield SI-5p (1.65 g, 71\% yield) as a colorless solid.

${ }^{1} \mathrm{H}$ NMR $\left(\mathrm{CDCl}_{3}, 400 \mathrm{MHz}\right): \delta 9.20(\mathrm{~d}, J=2.4 \mathrm{~Hz}, 1 \mathrm{H}), 8.32(\mathrm{~d}, J=2.3 \mathrm{~Hz}, 1 \mathrm{H}), 8.15(\mathrm{~d}, J=8.5$ $\mathrm{Hz}, 1 \mathrm{H}), 7.89(\mathrm{dd}, J=8.2,1.5 \mathrm{~Hz}, 1 \mathrm{H}), 7.76-7.68(\mathrm{~m}, 3 \mathrm{H}), 7.62-7.55(\mathrm{~m}, 3 \mathrm{H}), 6.79$ (dd, $J=17.6$, $10.9 \mathrm{~Hz}, 1 \mathrm{H}), 5.85(\mathrm{~d}, J=17.6 \mathrm{~Hz}, 1 \mathrm{H}), 5.34(\mathrm{~d}, J=10.9 \mathrm{~Hz}, 1 \mathrm{H})$.

${ }^{13} \mathrm{C} \mathrm{NMR}\left(\mathrm{CDCl}_{3}, 101 \mathrm{MHz}\right): \delta$ 149.8, 147.3, 137.6, 137.2, 136.3, 133.6, 133.2, 129.6, 129.3, 128.2, 128.2, 127.5, 127.1, 127.1114 .7 . 
IR (Diamond-ATR, neat) $\widetilde{v}_{\text {max }}: 3086,3059,1627,1519,1494,1125,990,951,576$.

HRMS (DART) m/z: [M+H] $]^{+}$calcd. for $\mathrm{C}_{17} \mathrm{H}_{14} \mathrm{~N}^{+}: 232.1121$. Found: 232.1126.

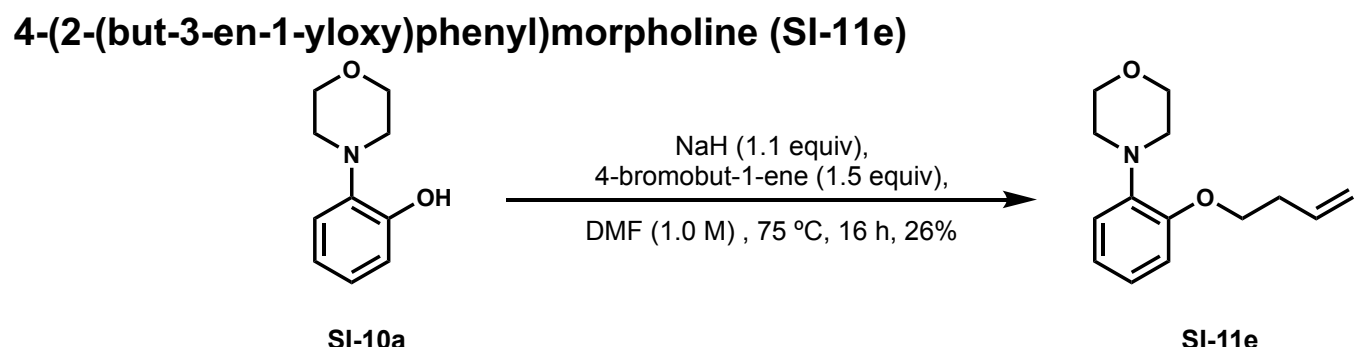

To an oven-dried reaction tube (Fisherbrand, 20x150 mm, 1495937C) equipped with a magnetic stir bar was added sodium hydride $(88.4 \mathrm{mg}, 3.31 \mathrm{mmol}, 1.1$ equiv, 90\%), and DMF (1.5 $\mathrm{mL}, 2.2 \mathrm{M}$ ). The tube was sealed with a PTFE screw cap, attached by rubber hose via a needle to a dual manifold Schlenk line, and placed under $\mathrm{N}_{2}$ atmosphere. The reaction vessel was transferred to a $0{ }^{\circ} \mathrm{C}$ ice-water bath. To the stirred reaction mixture was added (via syringe by puncturing the PTFE septum) a solution of 2-morpholinophenol SI-10a (550 mg, $3.1 \mathrm{mmol}, 1.0$ equiv) in DMF (1.5 mL, $2.0 \mathrm{M})$ dropwise over $5 \mathrm{~min}$ (CAUTION! gas evolution). After the reaction mixture had stirred for $10 \mathrm{~min}$, 4-bromobut-1-ene $(0.47 \mathrm{~mL}, 4.6 \mathrm{mmol}, 1.5$ equiv) was added dropwise over 2 min via syringe by puncturing the rubber septum. The ice-water bath was removed and the reaction was transferred to an oil bath preheated to $75^{\circ} \mathrm{C}$.

After the reaction had stirred for $16 \mathrm{~h}$ at $75^{\circ} \mathrm{C}$, the reaction vessel was removed from the oil bath and allowed to cool to room temperature. Once at room temperature, the reaction mixture was diluted with sat. aq. $\mathrm{NH}_{4} \mathrm{Cl}(5 \mathrm{~mL})$ and EtOAc $(5 \mathrm{~mL})$. The layers were separated and the aqueous layer was extracted with EtOAc $(3 \times 5 \mathrm{~mL})$. The combined organic layers were washed with brine $(10 \mathrm{~mL})$, dried over $\mathrm{Na}_{2} \mathrm{SO}_{4}$, filtered and concentrated in vacuo with the aid of a rotary evaporator. Purification by automated flash column chromatography $\left(25 \mathrm{~g} \mathrm{SiO}_{2}\right.$, gradient elution: $5 \%$ EtOAc in hexane to 40\% EtOAc in hexane) afforded SI-11e (189 mg, 26\%) as a colorless oil.

${ }^{1} \mathrm{H}$ NMR $\left(\mathrm{CDCl}_{3}, 400 \mathrm{MHz}\right): \delta 7.01-6.85(\mathrm{~m}, 4 \mathrm{H}), 5.96-5.84(\mathrm{~m}, 1 \mathrm{H}), 5.19(\mathrm{dq}, J=17.2,1.7 \mathrm{~Hz}$, $1 \mathrm{H}), 5.10(\mathrm{~d}, J=10.2 \mathrm{~Hz}, 1 \mathrm{H}), 4.06(\mathrm{t}, J=6.4 \mathrm{~Hz}, 2 \mathrm{H}), 3.87$ (dd, $J=4.5,4.5 \mathrm{~Hz}, 4 \mathrm{H}$ ), 3.09 (dd, $J$ $=4.5,4.5 \mathrm{~Hz}, 4 \mathrm{H}$ ), 2.61 (qt, $J=6.5,1.5 \mathrm{~Hz}, 2 \mathrm{H}$ ).

${ }^{13} \mathrm{C}$ NMR $\left(\mathrm{CDCl}_{3}, 101 \mathrm{MHz}\right): \delta 151.6,141.3,135.1,123.1,121.3,118.1,117.2,112.5,67.4,67.3$, 51.2, 34.1.

IR (Diamond-ATR, neat) $\widetilde{v}_{\text {max }}: 2954,2853,2816,1594,1500,1237,1170,934$.

EA calcd. for $\mathrm{C}_{14} \mathrm{H}_{19} \mathrm{NO}_{2}$ : C, 72.07; $\mathrm{H}, 8.21$. Found: $\mathrm{C}, 72.22 ; \mathrm{H}, 8.31$.

\section{2-(but-3-en-1-ylthio)pyrimidine (SI-11f)}

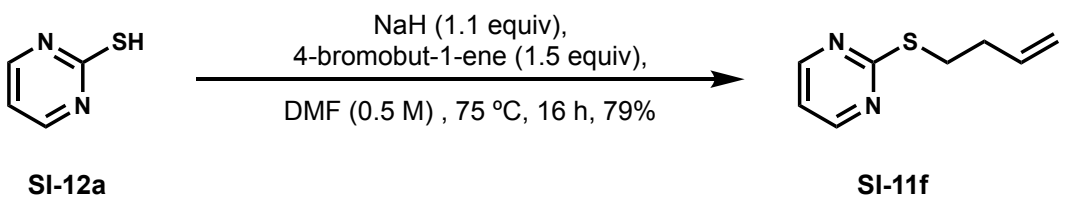

To an oven-dried reaction tube (Fisherbrand, 20x150 mm, 1495937C) equipped with a magnetic stir bar was added sodium hydride $(86 \mathrm{mg}, 3.2 \mathrm{mmol}, 1.1$ equiv, $90 \%)$ and DMF (3.0 mL, $1.2 \mathrm{M})$. The tube was sealed with a PTFE screw cap, attached by rubber hose via a needle to a dual manifold Schlenk line, and placed under $\mathrm{N}_{2}$ atmosphere. The reaction vessel was transferred to a $0{ }^{\circ} \mathrm{C}$ ice-water bath. To the stirred reaction mixture was added (via syringe by puncturing the PTFE septum) a solution of pyrimidine-2-thiol (SI-12a) (336 mg, $3.0 \mathrm{mmol}, 1.0$ equiv) in DMF (3.0 
$\mathrm{mL}, 1.0 \mathrm{M}$ ) dropwise over $5 \mathrm{~min}$ (CAUTION! gas evolution), to achieve a reaction concentration of $0.5 \mathrm{M}$. After the reaction mixture had stirred for $10 \mathrm{~min}$, 4-bromobut-1-ene $(0.46 \mathrm{~mL}, 4.5 \mathrm{mmol}, 1.5$ equiv) was added dropwise over 2 min via syringe by puncturing the PTFE septum. The ice-water bath was removed and the reaction was transferred to an oil bath preheated to $60^{\circ} \mathrm{C}$.

After the reaction had stirred for $16 \mathrm{~h}$ at $75^{\circ} \mathrm{C}$, the reaction vessel was removed from the oil bath and allowed to cool to room temperature. Once at room temperature, the reaction mixture was diluted with sat. aq. $\mathrm{NH}_{4} \mathrm{Cl}(5 \mathrm{~mL})$ and EtOAc $(5 \mathrm{~mL})$, then transferred to a separatory funnel. The layers were separated, and the aqueous layer was extracted with EtOAc $(3 \times 15 \mathrm{~mL})$. The combined organic layers were washed with brine $(10 \mathrm{~mL})$, dried over $\mathrm{Na}_{2} \mathrm{SO}_{4}$, filtered and concentrated in vacuo with the aid of a rotary evaporator. Purification by automated flash column chromatography (50 $\mathrm{g} \mathrm{SiO}_{2}$, gradient elution: hexane to $35 \%$ EtOAc in hexane) afforded SI-11f (392 mg, 79\%) as a light-yellow oil.

${ }^{1} \mathrm{H}$ NMR $\left(\mathrm{CDCl}_{3}, 400 \mathrm{MHz}\right): \delta 8.49(\mathrm{~d}, J=4.9 \mathrm{~Hz}, 2 \mathrm{H}), 6.94(\mathrm{t}, J=4.8 \mathrm{~Hz}, 1 \mathrm{H}), 5.94-5.82(\mathrm{~m}, 1 \mathrm{H})$, $5.11(\mathrm{~d}, J=17.1 \mathrm{~Hz}, 1 \mathrm{H}), 5.05(\mathrm{~d}, J=10.2 \mathrm{~Hz}, 1 \mathrm{H}), 3.20(\mathrm{t}, J=7.4 \mathrm{~Hz}, 2 \mathrm{H}), 2.49(\mathrm{q}, J=7.1 \mathrm{~Hz}$, $2 \mathrm{H})$.

${ }^{13} \mathrm{C}$ NMR $\left(\mathrm{CDCl}_{3}, 101 \mathrm{MHz}\right): \delta 172.6,157.3,136.6,116.5,116.4,33.4,30.2$.

IR (Diamond-ATR, neat) $\widetilde{v}_{\text {max }}: 2978,2931,1640,1545,1377,1184,993,915,773$.

HRMS (DART) m/z: $[\mathrm{M}+\mathrm{H}]^{+}$calcd. for $\mathrm{C}_{8} \mathrm{H}_{11} \mathrm{~N}_{2} \mathrm{~S}^{+}:$167.0637. Found: 167.0637 . 


\section{Synthesis and Characterization of Hydroalkenylation Products}

\subsection{General Procedure $\mathbf{C}$ for Hydroalkenylation of Olefins}

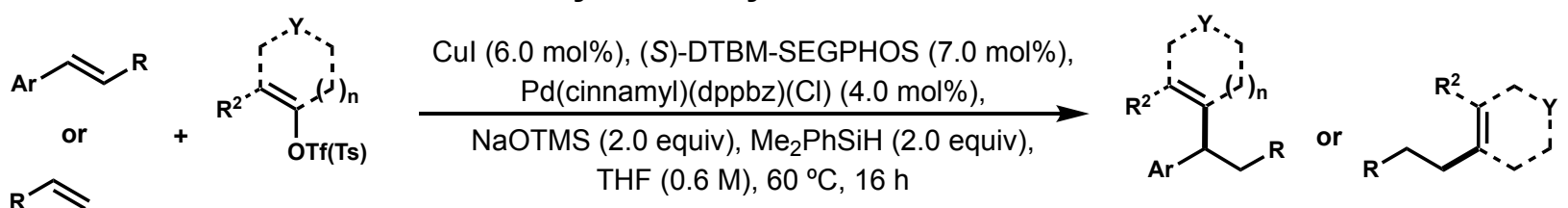

\section{(1.0 equiv) (1.5 equiv)}

Inside a nitrogen-filled glovebox, an oven-dried reaction tube (Fisherbrand, 20x125 mm, 1495937A) equipped with a magnetic stir bar, (tube A), was charged with (S)-DTBM-SEGPHOS (L1) (41 mg, $35 \mu \mathrm{mol}, 7.0 \mathrm{~mol} \%$ ), Cul (5.7 mg, $30 \mu \mathrm{mol}, 6.0 \mathrm{~mol} \%$ ), NaOTMS (112 mg, $1.00 \mathrm{mmol}, 2.0$ equiv) and THF $(475 \mu \mathrm{L})$, see Figure SI-1.2 and SI-2.3. To an oven-dried one-dram vial (Kimble 60910L-1), (vial B), was added the alkenyl coupling partner ( $0.75 \mathrm{mmol}, 1.5$ equiv) and THF (400 $\mu \mathrm{L}, 1.9 \mathrm{M}$ ). The one-dram vial was capped with a screw cap (Kimble 1000190PK-72) and allowed to stand at room temperature (Figure SI-2.4).

After the reaction mixture had stirred for $10 \mathrm{~min}$ at room temperature, $\mathrm{Me}_{2} \mathrm{PhSiH}(153 \mu \mathrm{L}$, $1.00 \mathrm{mmol}, 2.0$ equiv) was added dropwise to reaction tube $\mathbf{A}$ using a $250 \mu \mathrm{L}$ Hamilton Syringe (Figure SI3.5). Once the reaction mixture had stirred for an additional 10 min (Figure SI-3.6), the corresponding alkene (1 or 5$)(0.5 \mathrm{mmol}, 1.0$ equiv) was added to the reaction mixture and allowed to stir for $2 \mathrm{~min}$. Then, $\mathrm{Pd}($ cinnamyl)(dppbz)(Cl) $(14 \mathrm{mg}, 0.20 \mathrm{mmol}, 4.0 \mathrm{~mol} \%)$ was added to the reaction mixture in one portion, resulting in a red-orange-colored reaction mixture (Figure SI-4.7). The entirety of one-dram vial $\mathbf{B}$, containing the alkenyl coupling partner solution, was added to the reaction mixture using a $500 \mu \mathrm{L}$ Hamilton syringe (Figure SI-4.8).

Reaction tube A was sealed with a screw cap containing a PTFE septum (cap: Kimble Chase Open Top S/T Closure catalog no. 73804-15425; Septum: Thermo Scientific $1.3 \mathrm{~mm}$ silicone/PTFE catalog no. B7995-18), taken outside the glovebox and placed in an oil bath preheated to $60{ }^{\circ} \mathrm{C}$ (Figure SI-5.9).

After the reaction mixture had stirred for $16 \mathrm{~h}$ at $60^{\circ} \mathrm{C}$, the reaction vessel was removed from the oil bath and the reaction mixture was allowed cool to room temperature (Figure SI-5.10). Once the reaction mixture had cooled to room temperature, the reaction mixture was diluted with EtOAc $(5 \mathrm{~mL})$ and filtered through a $1 \mathrm{~cm}$ pad of packed Celite (Figure SI-6.11) using a glass fritted funnel, which was subsequently washed with additional EtOAc $(2 \times 5 \mathrm{~mL})$. The filtrate was concentrated in vacuo with the aid of a rotary evaporator. The resulting crude residue was purified by silica flash column chromatography or reversed-phase chromatography (see General Procedure D).

For unactivated olefins (5) ( \pm )-L1 was used in place of L1. 


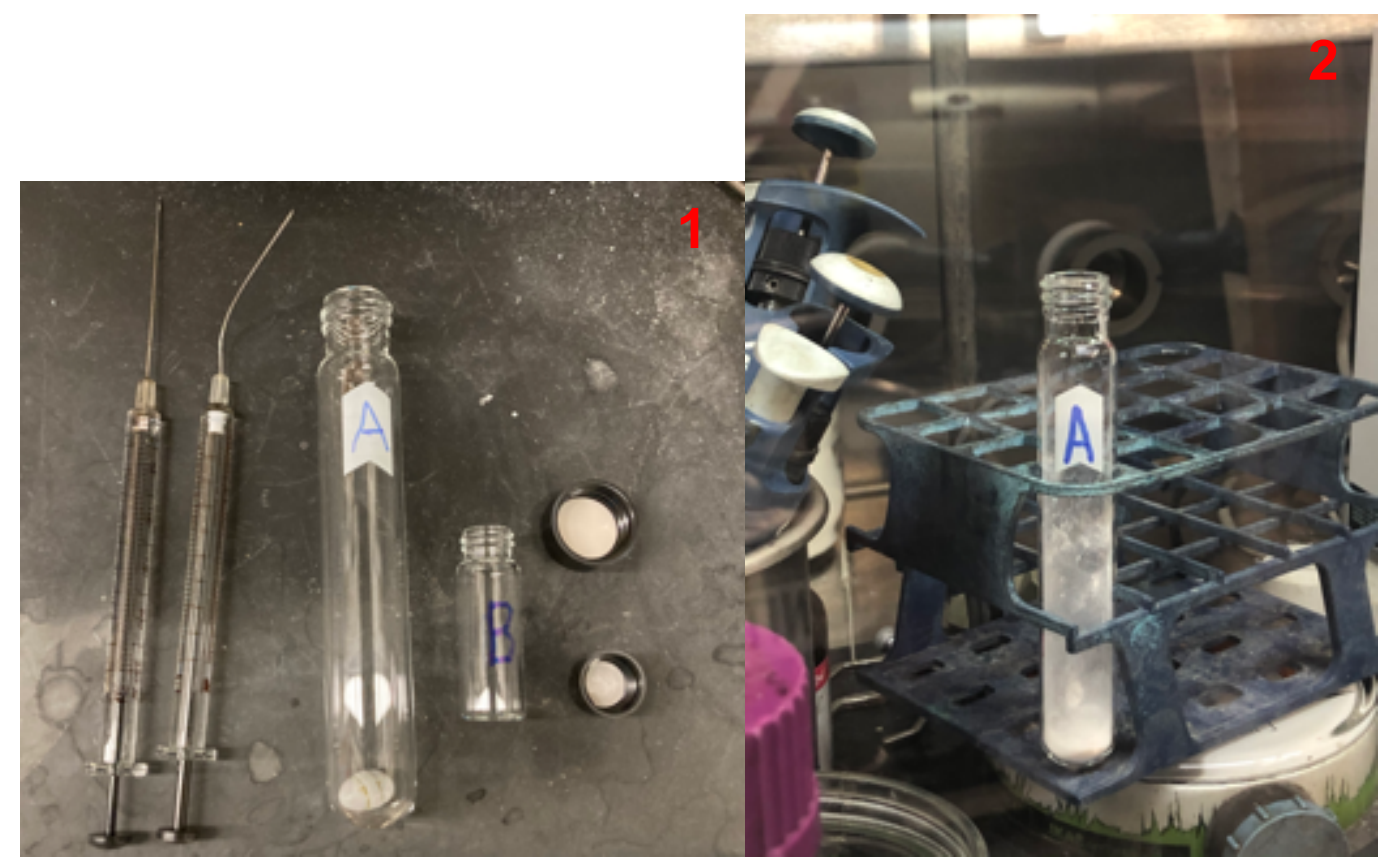

Figure SI-1: 1. Reaction vessels (A, Fisherbrand, 20x125 mm, 1495937A; B, onedram vial), syringes (250 and $500 \mu \mathrm{L}$ Hamilton syringes) and reaction caps (top cap (A): Kimble Chase Open Top S/T Closure catalog no. 73804-15425; Septum: Thermo Scientific $1.3 \mathrm{~mm}$ silicone/PTFE catalog no. B7995-18; B, one-dram vial cap) used in reaction set up. 2 . Image of reaction tube $\mathbf{A}$, in a nitrogen-filled glovebox, following addition of NaOTMS (112 mg, $1.00 \mathrm{mmol})$, L1 (41 mg, $35 \mu \mathrm{mol})$ and Cul (5.7 mg, $30 \mu \mathrm{mol})$ with a stainless steel spatula.

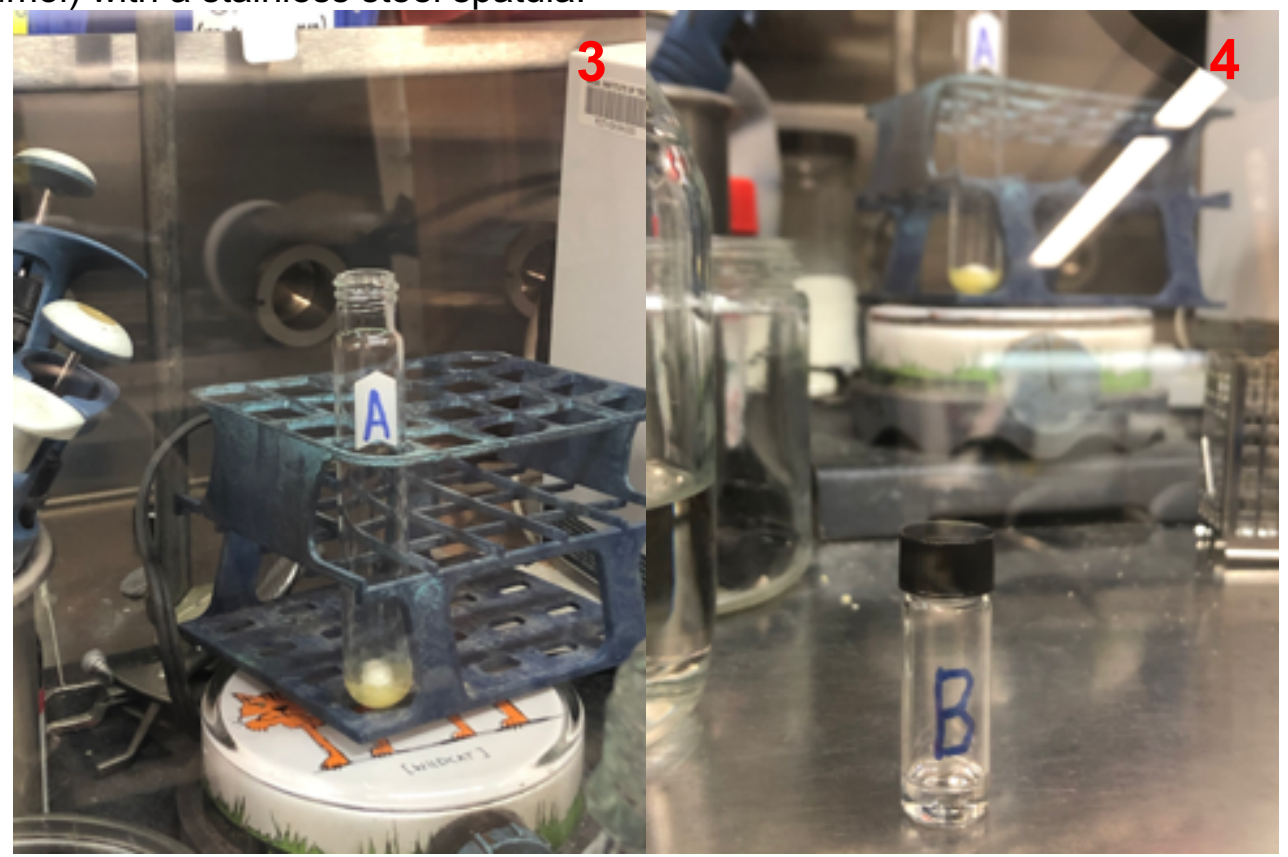

Figure SI-2: 3. Reaction tube A following the addition of THF $(475 \mu \mathrm{L}$, using a 500 $\mu \mathrm{L}$ Hamilton syringe) to the stirred solids. 4. While reaction tube $\mathbf{A}$ was allowed to stir for $10 \mathrm{~min}$, a capped scintillation vial (B) which contained alkenyl coupling partner $(0.75 \mathrm{mmol})$ and THF $(400 \mu \mathrm{L}$, using a $500 \mu \mathrm{L}$ Hamilton syringe) was prepared. 


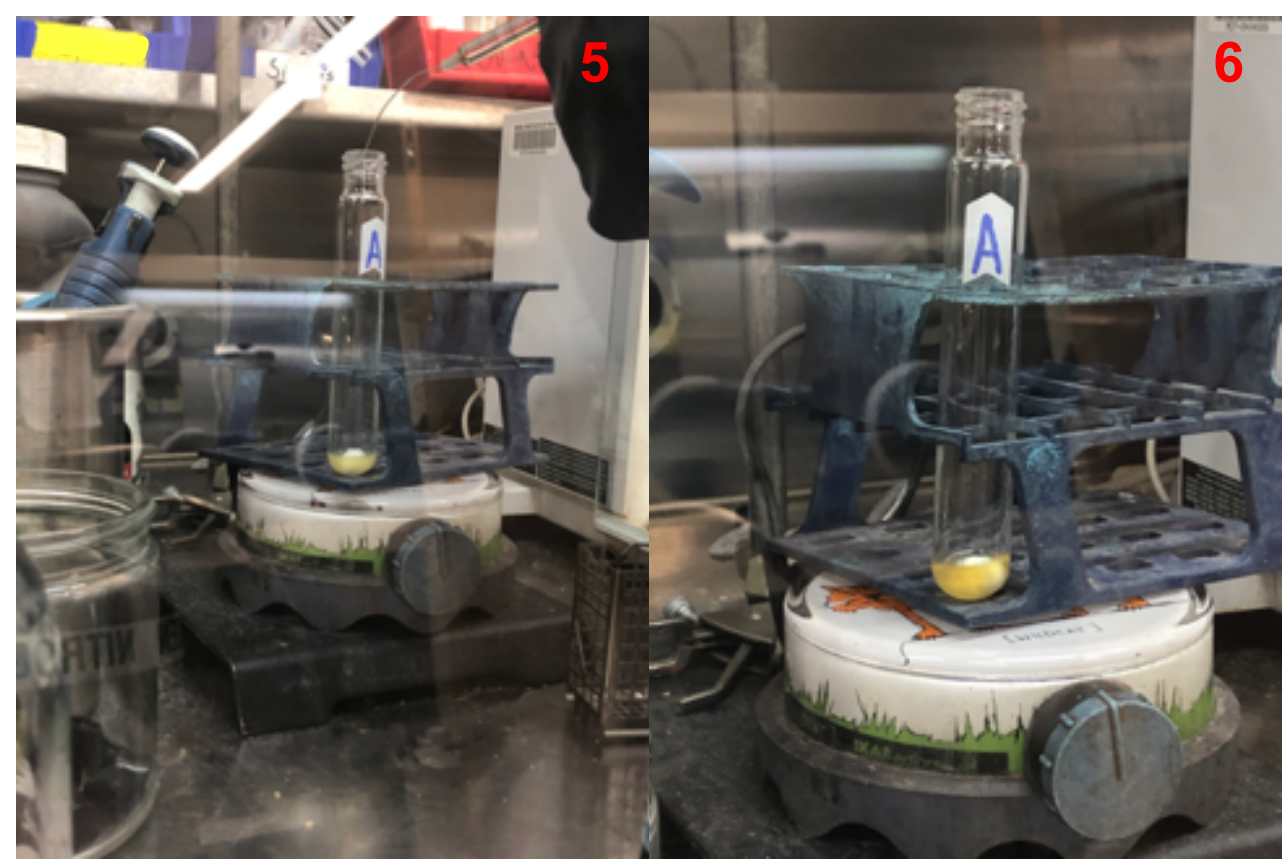

Figure SI-3: 5. After the reaction mixture $(\mathbf{A})$ had stirred for $10 \mathrm{~min}, \mathrm{Me}_{2} \mathrm{PhSiH}(153$ $\mu \mathrm{L}, 1.0 \mathrm{mmol}$ ) was added using a $250 \mu \mathrm{L}$ Hamilton syringe. 6. Appearance of reaction mixture $(\mathbf{A})$ after stirring with silane for $10 \mathrm{~min}$.

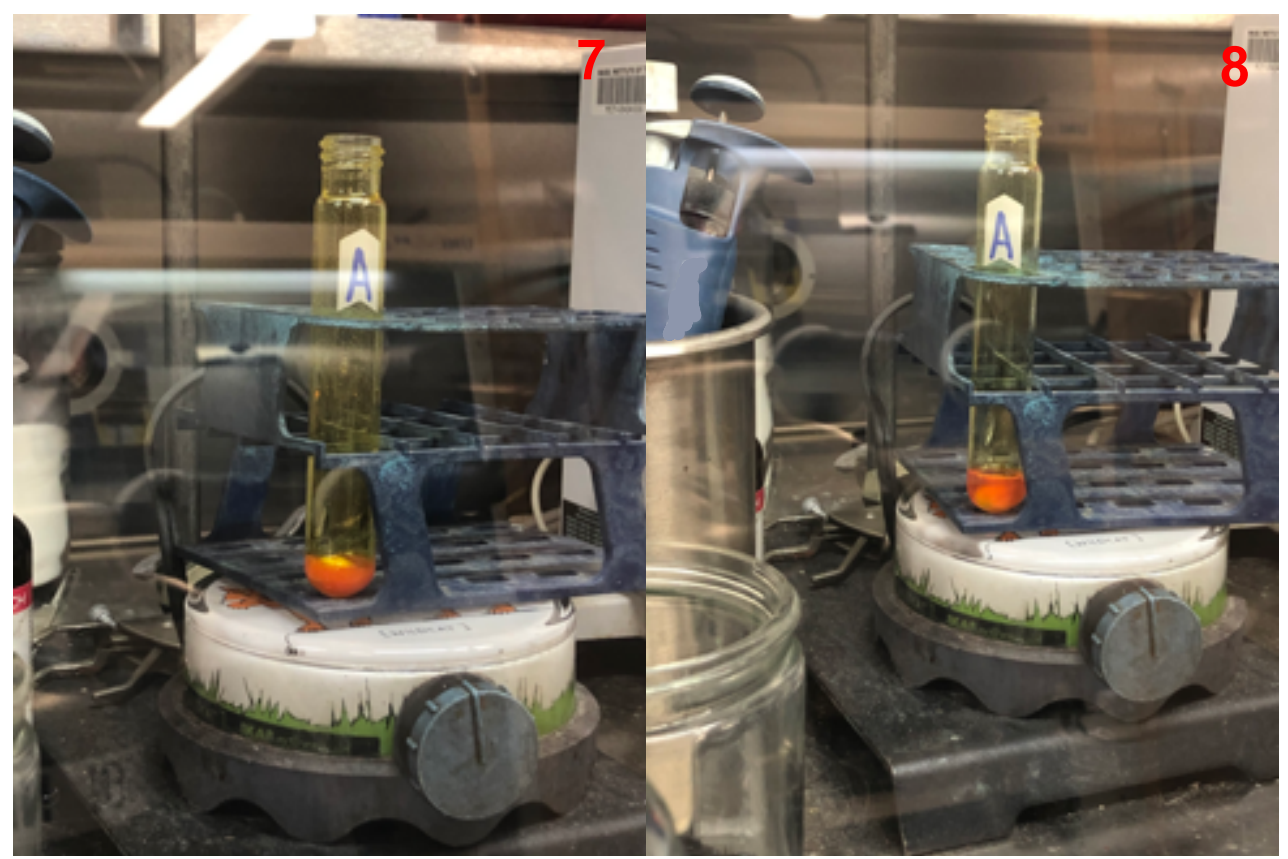

Figure SI-4: 7. Appearance of reaction mixture (A) immediately following the addition of alkene (0.5 mmol) and P1 (14 mg, $4.0 \mathrm{~mol} \%$ ). 8. Appearance of reaction mixture (A) after the entirety of the triflate solution in dram vial B was added with a $500 \mu \mathrm{L}$ Hamilton syringe. 


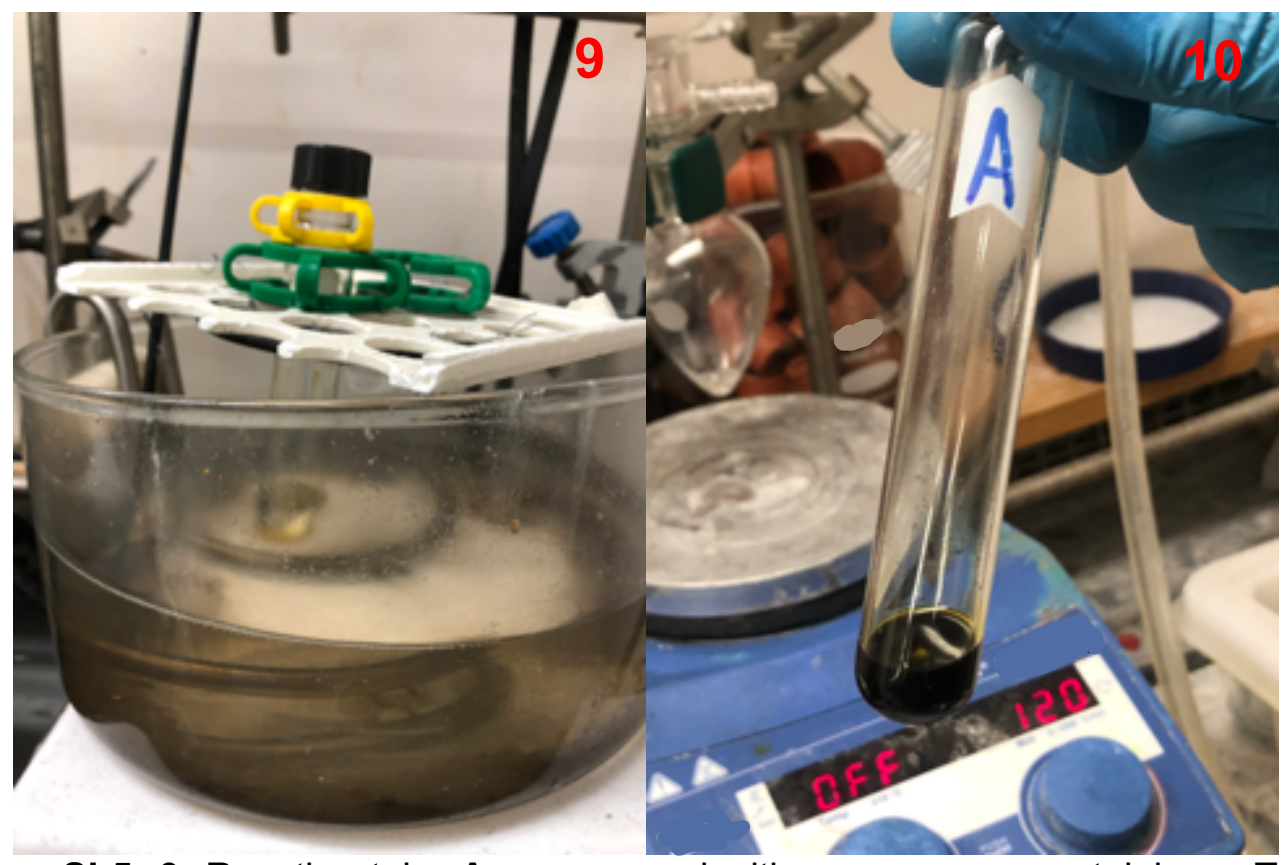

Figure SI-5: 9. Reaction tube A was capped with a screw cap containing a Teflon septum (cap: Kimble Chase Open Top S/T Closure catalog no. 73804-15425; Septum: Thermo Scientific $1.3 \mathrm{~mm}$ silicone/PTFE catalog no. B7995-18) and removed from the glove box. On the bench top, the reaction tube $\mathbf{A}$ was placed in a preheated $60^{\circ} \mathrm{C}$ oil bath. 10. Appearance of reaction mixture $(\mathbf{A})$ after reaction mixture had stirred at 60 ${ }^{\circ} \mathrm{C}$ for 16 hours, and the reaction vessel had cooled to room temperature.

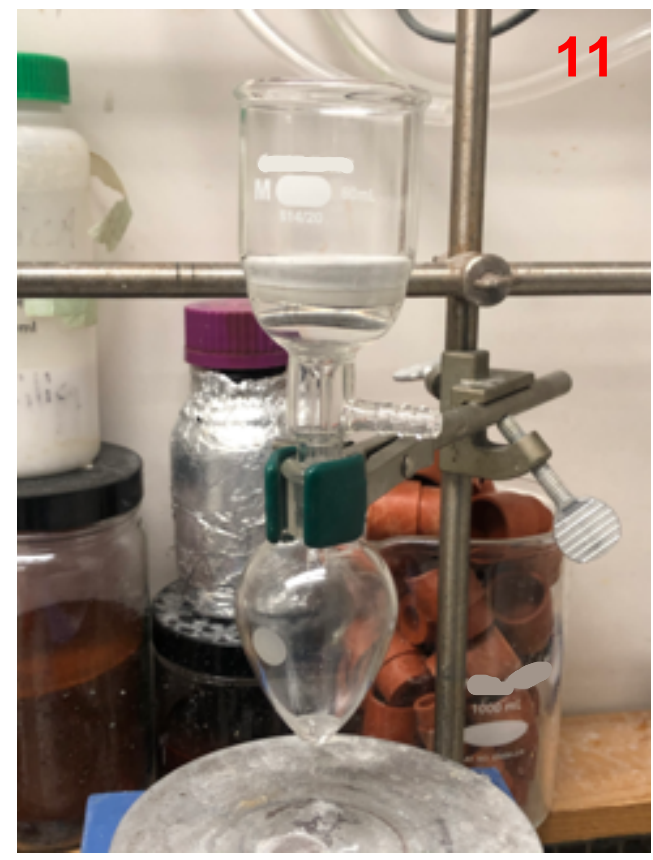

Figure SI-6: 11. Apparatus used for filtration of the crude reaction mixture: glass fritted funnel containing $1 \mathrm{~cm}$ of Celite connected to a $50 \mathrm{~mL}$ recovery flask. The Celite was wetted with $5 \mathrm{~mL}$ of EtOAc and packed with the aid of reduced pressure. The filtrate from this packing step was discarded. The reaction mixture was diluted with EtOAc $(5 \mathrm{~mL})$ and filtered through the packed Celite, which was subsequently washed with additional EtOAc $(2 \times 5 \mathrm{~mL})$. The filtrate was concentrated in vacuo with the aid of a rotary evaporator. 


\subsection{General Procedure D: Purification by Reversed-Phase Chromatography}

The crude residue from General Procedure $\mathbf{C}$ was dissolved in a minimal amount of DMSO (ca. $1.5 \mathrm{~mL}$ ) and loaded onto a C18 column (grams of stationary phase used are listed in parenthesis). After the chromatography was complete, the test tubes containing the product were combined into a $500 \mathrm{~mL}$ round-bottom flask and the test tubes were each washed with acetone (ca. $2 \mathrm{~mL}$ ). The mixture was concentrated in vacuo with the aid of a rotary evaporator to remove the acetonitrile and acetone. Once only the aqueous phase remained, the flask was removed from the rotary evaporator, transferred to a separatory funnel and diluted with EtOAc $(50 \mathrm{~mL})$ and sat. aq. $\mathrm{Na}_{2} \mathrm{CO}_{3}(50 \mathrm{~mL})$. The layers were separated and the aqueous layer was extracted with EtOAc $(2 \times 50 \mathrm{~mL})$. The combined organic layers were washed with brine $(25 \mathrm{~mL})$, dried over $\mathrm{Na}_{2} \mathrm{SO}_{4}$, filtered and concentrated in vacuo with the aid of a rotary evaporator to yield the corresponding olefin hydroalkenylation product. 


\subsection{Characterization of Enantioselective Hydroalkenylation Products (S)-(1-(cyclohex-1-en-1-yl)ethyl)benzene (3a)}<smiles>C[C@H](C1=CCCCC1)c1ccccc1</smiles>

Prepared according to General Procedure C using styrene (1a) (52 mg, $0.50 \mathrm{mmol}$, 1.0 equiv) and cyclohex-1-en-1-yl trifluoromethanesulfonate (2a) $(170 \mathrm{mg}, 0.75 \mathrm{mmol}, 1.5$ equiv). NMR yield was determined by ${ }^{1} \mathrm{H}$ NMR spectroscopy of the crude reaction mixture, using 1,1,2,2tetrachloroethane as internal standard. An analytically pure sample of $3 \mathbf{a}$ was purified by silica preparative TLC (hexanes) (1st run: 96\%, 96:4 er; 2nd run: 94\%, 96:4 er) and isolated as a colorless oil.

${ }^{1} \mathrm{H}$ NMR $\left(\mathrm{CDCl}_{3}, 500 \mathrm{MHz}\right): \delta 7.30-7.26(\mathrm{~m}, 2 \mathrm{H}), 7.20(\mathrm{~d}, J=7.5 \mathrm{~Hz}, 2 \mathrm{H}), 7.18-7.15(\mathrm{~m}, 1 \mathrm{H})$, 5.61-5.57 (m, 1H), 3.29 (q, J = 7.2 Hz, 1H), 2.09-2.03 (m, 2H), 1.83-1.73 (m, 2H), 1.58-1.50 (m, $4 \mathrm{H}), 1.34(\mathrm{~d}, J=7.1 \mathrm{~Hz}, 3 \mathrm{H})$.

${ }^{13} \mathrm{C}$ NMR $\left(\mathrm{CDCl}_{3}, 126 \mathrm{MHz}\right): \delta 146.1,141.3,128.3,127.6,125.9,120.8,46.7,27.3,25.5,23.2$, 22.8, 19.9 .

Specific Rotation $[\alpha]^{23}{ }_{\mathrm{D}}:-12.4\left(c=0.21, \mathrm{CHCl}_{3}\right)$. Lit. $[\alpha]^{24.7} \mathrm{D}:-4.2\left(c=0.21, \mathrm{CHCl}_{3}\right) .{ }^{25}$

Chiral SFC: Chiralcel OJ-H $\left(\mathrm{scCO}_{2} / \mathrm{IPA}=98 / 2\right.$ to $95 / 5$ over $8 \mathrm{~min}, 2.5 \mathrm{~mL} / \mathrm{min}, 210-400 \mathrm{~nm}, 45$ $\left.{ }^{\circ} \mathrm{C}\right), 3.51 \mathrm{~min}$ (minor) and $3.72 \mathrm{~min}$ (major).

Characterization data for $\mathbf{3 a}$ is consistent with that previously reported. ${ }^{25}$

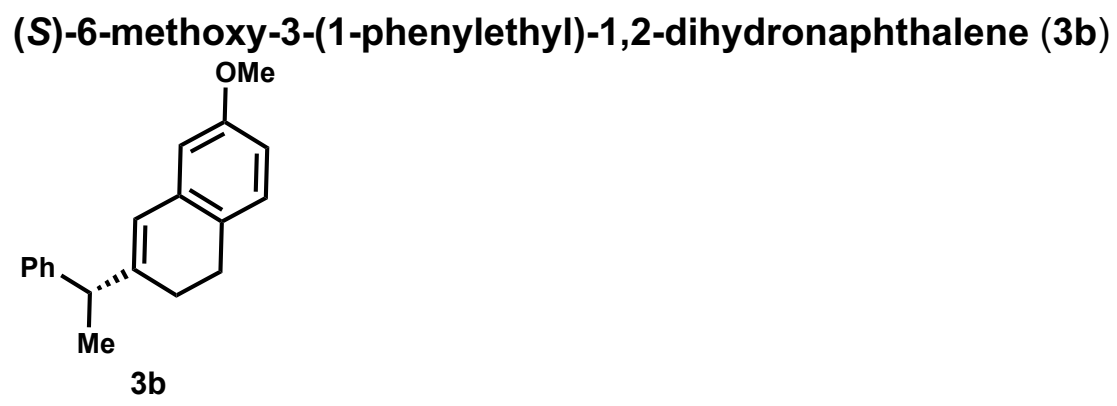

Prepared according to General Procedure C using styrene (1a) (52 mg, $0.50 \mathrm{mmol}, 1.0$ equiv) and 7-methoxy-3,4-dihydronaphthalen-2-yl trifluoromethanesulfonate (SI-2q) $(230 \mathrm{mg}, 0.75 \mathrm{mmol}$, 1.5 equiv). The residue was purified by flash column chromatography on silica gel (gradient elution: hexane to $15 \% \mathrm{CH}_{2} \mathrm{Cl}_{2}$ in hexane) to yield $\mathbf{3 b}$ ( $1^{\text {st }}$ run: $94 \mathrm{mg}, 71 \%, 98: 2 \mathrm{er} ; 2^{\text {nd }}$ run: $92 \mathrm{mg}, 70 \%$, 96:4 er) as a colorless oil.

${ }^{1} \mathrm{H}$ NMR $\left(\mathrm{CDCl}_{3}, 400 \mathrm{MHz}\right): \delta 7.33-7.25(\mathrm{~m}, 4 \mathrm{H}), 7.24-7.19(\mathrm{~m}, 1 \mathrm{H}), 6.99(\mathrm{~d}, J=9.0 \mathrm{~Hz}, 1 \mathrm{H})$, 6.67-6.65 (m, 2H), $6.37(\mathrm{~s}, 1 \mathrm{H}), 3.81(\mathrm{~s}, 3 \mathrm{H}), 3.59(\mathrm{q}, J=7.1 \mathrm{~Hz}, 1 \mathrm{H}), 2.66(\mathrm{td}, J=8.2,2.6 \mathrm{~Hz}$, $2 \mathrm{H}), 2.10(\mathrm{t}, J=8.0 \mathrm{~Hz}, 2 \mathrm{H}), 1.49(\mathrm{~d}, J=7.0 \mathrm{~Hz}, 3 \mathrm{H})$.

${ }^{13} \mathrm{C}$ NMR $\left(\mathrm{CDCl}_{3}, 101 \mathrm{MHz}\right): \delta$ 158.5, 146.2, 145.1, 135.9, 128.5, 128.0, 127.8, 127.0, 126.4, 122.0, $111.7,55.5,46.3,27.5,27.0,19.8$.

IR (Diamond-ATR, neat) $\widetilde{\boldsymbol{v}}_{\max }:$ 3024, 2964, 2930, 2878, 2830, 1603, 1492, 1264, 1156, 1036, 803.

Specific Rotation $[\alpha]^{23} \mathrm{D}:-8.4\left(c=1.0, \mathrm{CHCl}_{3}\right)$.

HRMS (DART) m/z: $[\mathrm{M}+\mathrm{H}]^{+}$calcd. for $\mathrm{C}_{19} \mathrm{H}_{21} \mathrm{O}^{+}:$265.1587. Found: 265.1594. 
Chiral SFC: Chiralcel OJ-H $\left(\mathrm{scCO}_{2} / \mathrm{IPA}=95 / 5\right.$ to $60 / 40$ over $8 \mathrm{~min}, 2.5 \mathrm{~mL} / \mathrm{min}, 210-400 \mathrm{~nm}, 45$ $\left.{ }^{\circ} \mathrm{C}\right), 5.62 \mathrm{~min}$ (minor) and $6.19 \mathrm{~min}$ (major).

\section{(S,E)-1-methoxy-4-(2-methyl-3-phenylbut-1-en-1-yl)benzene (3c)}<smiles>COc1ccc(/C=C(\C)[C@H](C)c2ccccc2)cc1</smiles>

Prepared according to General Procedure C using styrene (1a) (52 mg, $0.50 \mathrm{mmol}, 1.0$ equiv) and (E)-1-(4-methoxyphenyl)prop-1-en-2-yl trifluoromethanesulfonate (SI-2r) (220 mg, $0.75 \mathrm{mmol}$, 1.5 equiv, $6.5: 1 \mathrm{E}: \mathrm{Z})$. The residue was purified by automated flash column chromatography on silica gel (50 $\mathrm{g} \mathrm{SiO}_{2}$, gradient elution: hexane to $6.5 \% \mathrm{CH}_{2} \mathrm{Cl}_{2}$ in hexane) to yield $3 \mathrm{c}$ (1 ${ }^{\text {st }}$ run: 91 mg, 72\%, 97:3 er; $2^{\text {nd }}$ run: $88 \mathrm{mg}, 69 \%, 97: 3 \mathrm{er}, 3^{\text {rd }}$ run: $97 \mathrm{mg}, 76 \% 97: 3 \mathrm{er}$ ) as a colorless oil.

${ }^{1} \mathrm{H}$ NMR $\left(\mathrm{CDCl}_{3}, 400 \mathrm{MHz}\right): \delta$ 7.38-7.30 (m, 4H), 7.28-7.22 (m, 3H), 6.93-6.89 (m, 2H), $6.47(\mathrm{~s}$, $1 \mathrm{H}), 3.84(\mathrm{~s}, 3 \mathrm{H}), 3.60(\mathrm{q}, J=7.1 \mathrm{~Hz}, 1 \mathrm{H}), 1.74(\mathrm{~d}, J=1.4 \mathrm{~Hz}, 3 \mathrm{H}), 1.51(\mathrm{~d}, J=7.1 \mathrm{~Hz}, 3 \mathrm{H})$.

${ }^{13} \mathrm{C} \mathrm{NMR}\left(\mathrm{CDCl}_{3}, 101 \mathrm{MHz}\right): \delta 158.0,145.3,140.9,131.2,130.2,128.4,127.7,126.2,124.2,113.6$, $55.4,48.6,19.7,16.6$.

IR (Diamond-ATR, neat) $\widetilde{v}_{\text {max: }}$ 3024, 2963, 2834, 1606, 1509, 1245, 1175, 871, 642.

Specific Rotation $[\alpha]^{23}{ }_{\mathrm{D}}:+25.5\left(c=1.0, \mathrm{CHCl}_{3}\right)$.

EA calcd. for $\mathrm{C}_{18} \mathrm{H}_{20} \mathrm{O}$ : C, 85.67; $\mathrm{H}, 7.99$ Found: $\mathrm{C}, 85.61 ; \mathrm{H}, 8.07$.

Chiral SFC: Chiralcel OJ-H $\left(\mathrm{scCO}_{2} / \mathrm{IPA}=95 / 5\right.$ to $60 / 40$ over $8 \mathrm{~min}, 2.5 \mathrm{~mL} / \mathrm{min}, 210-400 \mathrm{~nm}, 45$

$\left.{ }^{\circ} \mathrm{C}\right), 4.14 \mathrm{~min}$ (minor) and $4.27 \mathrm{~min}$ (major).

\section{(S)-(2-methylbut-1-ene-1,1,3-triyl)tribenzene (3d)}

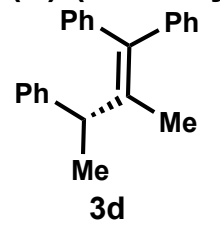

Prepared according to a modified General Procedure C using styrene (1a) (52 mg, $0.50 \mathrm{mmol}$, 1.0 equiv), 1,1-diphenylprop-1-en-2-yl (4-methylbenzenesulfonate) (SI-2a) (270 mg, $0.75 \mathrm{mmol}$, 1.5 equiv), and (S)-DTBM-MeO-BIPHEP (L2) $(40.3 \mathrm{mg}, 35 \mu \mathrm{mol}, 7.0 \mathrm{~mol} \%)$. The residue was purified by automated flash column chromatography on silica gel $\left(80 \mathrm{~g} \mathrm{SiO}_{2}\right.$, gradient elution: hexane to $25 \% \mathrm{CH}_{2} \mathrm{Cl}_{2}$ in hexane) to yield $3 \mathrm{~d}$ ( $1^{\text {st }}$ run: $129 \mathrm{mg}, 87 \%, 97: 3 \mathrm{er} ; 2^{\text {nd }}$ run: $127 \mathrm{mg}, 85 \%$, $97: 3$ er) as a colorless oil.

${ }^{1} \mathrm{H}$ NMR $\left(\mathrm{CDCl}_{3}, 400 \mathrm{MHz}\right): \delta 7.36-7.27(\mathrm{~m}, 7 \mathrm{H}), 7.26-7.15(\mathrm{~m}, 8 \mathrm{H}), 4.02(\mathrm{q}, J=7.1 \mathrm{~Hz}, 1 \mathrm{H}), 1.52$ (s, 3H), $1.46(\mathrm{~d}, J=7.1 \mathrm{~Hz}, 3 \mathrm{H})$.

${ }^{13} \mathrm{C}$ NMR $\left(\mathrm{CDCl}_{3}, 101 \mathrm{MHz}\right): \delta 144.6,143.5,143.2,138.3,138.1,129.7,129.3,128.4,128.2,128.1$, $127.5,126.5,126.3,125.9,41.4,17.6,14.9$.

IR (Diamond-ATR, neat) $\widetilde{v}_{\text {max: }}$ 3056, 3023, 2922, 1598, 1492, 1442, 1029, 696.

Specific Rotation $[\alpha]^{23}{ }_{D}:+28.1\left(c=1.0, \mathrm{CHCl}_{3}\right)$.

EA calcd. for $\mathrm{C}_{23} \mathrm{H}_{22}$ : C, 92.57; $\mathrm{H}, 7.43$ Found: C, 92.82; $\mathrm{H}, 7.66$.

Chiral SFC: Chiralcel OJ-H $\left(\mathrm{scCO}_{2} / \mathrm{IPA}=95 / 5\right.$ to $60 / 40$ over $8 \mathrm{~min}, 2.5 \mathrm{~mL} / \mathrm{min}, 210-400 \mathrm{~nm}, 45$ $\left.{ }^{\circ} \mathrm{C}\right), 4.30 \mathrm{~min}$ (minor) and $5.04 \mathrm{~min}$ (major).

Melting Point $\left({ }^{\circ} \mathrm{C}\right): 49-51$. 
$(S, E)-1-$ methoxy-2-(3-phenylbut-1-en-1-yl)benzene (E-3e)<smiles>COc1ccccc1/C=C/[C@H](C)c1ccccc1</smiles>

Prepared according to a modified General Procedure C using styrene (1a) (52 mg, $0.50 \mathrm{mmol}$, 1.0 equiv), (E)-1-(2-bromovinyl)-2-methoxybenzene (SI-2c) (160 mg, $0.75 \mathrm{mmol}, 1.5$ equiv) and (S)-DTBM-MeO-BIPHEP (L2) $(40.3 \mathrm{mg}, 35 \mu \mathrm{mol}, 7.0 \mathrm{~mol} \%)$. The residue was purified by flash column chromatography on silica gel (gradient elution: hexane to $5 \% \mathrm{CH}_{2} \mathrm{Cl}_{2}$ in hexane) to yield $E$ 3 e ( $1^{\text {st }}$ run: $82 \mathrm{mg}, 69 \%, 97: 3 \mathrm{er} ; 2^{\text {nd }}$ run: $\left.94 \mathrm{mg}, 79 \%, 97: 3 \mathrm{er}\right)$ as a yellow oil.

${ }^{1} \mathrm{H}$ NMR $\left(\mathrm{CDCl}_{3}, 400 \mathrm{MHz}\right): \delta 7.43(\mathrm{dd}, J=7.6,1.7 \mathrm{~Hz}, 1 \mathrm{H}), 7.35-7.28(\mathrm{~m}, 4 \mathrm{H}), 7.24-7.17(\mathrm{~m}, 2 \mathrm{H})$, 6.92-6.78 (m, 3H), $6.39(\mathrm{dd}, J=16.0,7.1 \mathrm{~Hz}, 1 \mathrm{H}), 3.85(\mathrm{~s}, 3 \mathrm{H}), 3.67(\mathrm{p}, J=6.9 \mathrm{~Hz}, 1 \mathrm{H}), 1.49(\mathrm{~d}$, $J=7.0 \mathrm{~Hz}, 3 \mathrm{H})$.

${ }^{13} \mathrm{C} \mathrm{NMR}\left(\mathrm{CDCl}_{3}, 101 \mathrm{MHz}\right): \delta$ 156.6, 146.2, 135.8, 128.6, 128.2, 127.4, 126.7, 126.6, 126.2, 123.2, 120.7, 111.0, 55.6, 43.2, 21.5.

IR (Diamond-ATR, neat) $\widetilde{\boldsymbol{v}}_{\text {max: }}$ 3025, 2963, 1597, 1488, 1436, 1239, 1101, 999, 972, 698.

Specific Rotation $[\alpha]^{23}{ }_{\mathrm{D}}:-27.7\left(c=1.0, \mathrm{CHCl}_{3}\right)$.

HRMS (DART) m/z: [M+H] $]^{+}$calcd. for $\mathrm{C}_{17} \mathrm{H}_{19} \mathrm{O}^{+}: 239.1430$. Found: 239.1450 .

Chiral SFC: Chiralcel OD-H ( $\mathrm{scCO}_{2} / \mathrm{IPA}=95 / 5$ to $85 / 15$ over $8 \mathrm{~min}, 2.5 \mathrm{~mL} / \mathrm{min}, 210-400 \mathrm{~nm}, 45$

$\left.{ }^{\circ} \mathrm{C}\right), 4.82 \mathrm{~min}$ (major) and $5.09 \mathrm{~min}$ (minor).

\section{(S,Z)-1-methoxy-2-(3-phenylbut-1-en-1-yl)benzene (Z-3e)}

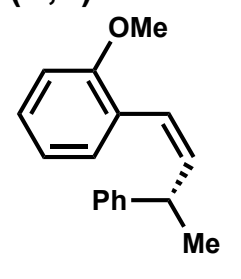

Z-3e

Prepared according to a modified General Procedure C using styrene (1a) (21 mg, $0.20 \mathrm{mmol}$, 1.0 equiv), (Z)-1-(2-bromovinyl)-2-methoxybenzene (SI-2b) (64 mg, $0.30 \mathrm{mmol}, 1.5$ equiv) and (S)DTBM-MeO-BIPHEP (L2) $(16.1 \mathrm{mg}, 14 \mu \mathrm{mol}, 7.0 \mathrm{~mol} \%)$. The residue was purified by automated flash column chromatography on silica gel $\left(25 \mathrm{~g} \mathrm{SiO}_{2}\right.$, gradient elution: hexane to $5 \% \mathrm{CH}_{2} \mathrm{Cl}_{2}$ in hexane) to yield Z-3e (37 mg, 78\%, 97:3 er) as a colorless oil.

${ }^{1} \mathrm{H}$ NMR $\left(\mathrm{CDCl}_{3}, 400 \mathrm{MHz}\right): \delta 7.35-7.17(\mathrm{~m}, 7 \mathrm{H}), 6.94-6.88(\mathrm{~m}, 2 \mathrm{H}), 6.56(\mathrm{~d}, J=11.5 \mathrm{~Hz}, 1 \mathrm{H})$, 5.90 (dd, $J=11.5,10.4 \mathrm{~Hz}, 1 \mathrm{H}$ ), 3.90 (dq, $J=10.3,6.9 \mathrm{~Hz}, 1 \mathrm{H}), 3.83(\mathrm{~s}, 3 \mathrm{H}), 1.38$ (d, J = $6.9 \mathrm{~Hz}$, $3 \mathrm{H})$.

${ }^{13} \mathrm{C} \mathrm{NMR}\left(\mathrm{CDCl}_{3}, 101 \mathrm{MHz}\right): \delta$ 157.3, 146.6, 137.0, 130.1, 128.6, 128.4, 127.1, 126.4, 126.1, 123.5, 120.2, 110.6, 55.6, 38.2, 23.1.

IR (Diamond-ATR, neat) $\widetilde{\boldsymbol{v}}_{\text {max }}:$ 3059, 3026, 2963, 2827, 1597, 1481, 1455, 1239, 1107, 1021, 699. Specific Rotation $[\alpha]^{23}$ : + $248.4\left(c=1.0, \mathrm{CHCl}_{3}\right)$.

HRMS (DART) m/z: $[\mathrm{M}+\mathrm{H}]^{+}$calcd. for $\mathrm{C}_{17} \mathrm{H}_{19} \mathrm{O}^{+}:$239.1430. Found: 239.1436.

Chiral SFC: Chiralcel OD-H ( $\mathrm{scCO}_{2} / \mathrm{IPA}=95 / 5$ to $85 / 15$ over $8 \mathrm{~min}, 2.5 \mathrm{~mL} / \mathrm{min}, 210-400 \mathrm{~nm}, 45$ $\left.{ }^{\circ} \mathrm{C}\right), 4.23 \mathrm{~min}$ (minor) and $4.44 \mathrm{~min}$ (major). 
<smiles>C/C(=C\c1cnc(N2CCOCC2)nc1)[C@@H](C)c1ccccc1</smiles>

Prepared according to General Procedure C using styrene (1a) (52 mg, $0.50 \mathrm{mmol}, 1.0$ equiv) and (E)-1-(5-morpholinopyrimidin-2-yl)prop-1-en-2-yl trifluoromethanesulfonate (SI-2t) (270 mg, $0.75 \mathrm{mmol}, 1.5$ equiv). The residue was purified by automated reversed-phase flash column chromatography according to General Procedure D $(40 \mathrm{~g} \mathrm{C} 18$, gradient elution: $5 \% \mathrm{MeCN}$ in water (0.1\% TFA) to $100 \% \mathrm{MeCN})$ to yield $\mathbf{3 f}$ ( $1^{\text {st }}$ run: $107 \mathrm{mg}, 69 \%, 98: 2 \mathrm{er} ; 2^{\text {nd }}$ run: $114 \mathrm{mg}, 74 \%$, 98:2 er) as a yellow oil.

${ }^{1} \mathrm{H}$ NMR $\left(\mathrm{CDCl}_{3}, 400 \mathrm{MHz}\right): \delta 8.28(\mathrm{~s}, 2 \mathrm{H}), 7.3-7.28(\mathrm{~m}, 2 \mathrm{H}), 7.27-7.19(\mathrm{~m}, 3 \mathrm{H}), 6.20(\mathrm{~s}, 1 \mathrm{H})$, 3.81-3.78 (m, 4H), 3.78-3.75 (m, 4H), $3.57(\mathrm{q}, J=7.1 \mathrm{~Hz}, 1 \mathrm{H}), 1.69(\mathrm{~d}, J=1.3 \mathrm{~Hz}, 3 \mathrm{H}), 1.47(\mathrm{~d}$, $J=7.1 \mathrm{~Hz}, 3 \mathrm{H})$.

${ }^{13} \mathrm{C} \mathrm{NMR}\left(\mathrm{CDCl}_{3}, 101 \mathrm{MHz}\right): \delta 160.1,157.6,144.7,143.3,128.5,127.6,126.4,121.2,118.1,66.9$, 48.6, 44.5, 19.7, 16.8 .

IR (Diamond-ATR, neat) $\widetilde{v}_{\text {max }}: 2962,2853,1594,1490,1444,1357,1189,956$.

Specific Rotation $[\alpha]^{23}{ }_{\mathrm{D}}$ : $+28.1\left(c=1.0, \mathrm{CHCl}_{3}\right)$.

HRMS (DART) m/z: [M+H] ${ }^{+}$calcd. for $\mathrm{C}_{19} \mathrm{H}_{24} \mathrm{NO}_{3}{ }^{+}: 310.1914$. Found: 310.1919 .

Chiral SFC: Chiralcel OD-H ( $\mathrm{scCO}_{2} / \mathrm{IPA}=95 / 5$ to $80 / 20$ over $20 \mathrm{~min}, 2.5 \mathrm{~mL} / \mathrm{min}, 210-400 \mathrm{~nm}, 45$ $\left.{ }^{\circ} \mathrm{C}\right), 8.65 \mathrm{~min}$ (major) and $8.92 \mathrm{~min}$ (minor).

\section{(S)-n-butyl-3-(1-(1-(benzo[b]thiophen-5-yl)-1,2,3,6-tetrahydropyridin-4-yl)ethyl)benzoate}

$(3 g)$<smiles>CCCCC(C)(C)OC(=O)c1cccc(C(C)C2=CCN(c3ccc4sccc4c3)CC2)c1</smiles>

Prepared according to General Procedure C using butyl 3-vinylbenzoate (SI-5k) (102 mg, 0.500 mmol, $\quad 1.0$ equiv) and 1-(benzo[b]thiophen-6-yl)-1,2,3,6-tetrahydropyridin-4-yl trifluoromethanesulfonate (SI-2s) $(270 \mathrm{mg}, 0.75 \mathrm{mmol}, 1.5 \mathrm{equiv})$. The residue was purified by automated reversed-phase flash column chromatography according to General Procedure D (40 g C18, gradient elution: $5 \%$ MeCN in water $\left(0.1 \%\right.$ TFA) to $100 \% \mathrm{MeCN}$ ) to yield $\mathbf{3 g}$ ( $1^{\text {st }}$ run: 115 $\mathrm{mg}, 55 \%, 90: 10 \mathrm{er} ; 2^{\text {nd }}$ run: $114 \mathrm{mg}, 54 \%, 87: 13 \mathrm{er}$ ) as a yellow oil.

Note: Decomposition of the product was observed over the course of ca. 1-2 $\mathrm{h}$ at ambient temperature on the benchtop. The product can be stored for longer periods of time under $\mathrm{N}_{2}$ atmosphere at $-20^{\circ} \mathrm{C}$. 
${ }^{1} \mathrm{H}$ NMR $\left(\mathrm{CDCl}_{3}, 400 \mathrm{MHz}\right): \delta 7.92(\mathrm{t}, J=1.6 \mathrm{~Hz}, 1 \mathrm{H}), 7.89(\mathrm{dt}, J=7.5,1.6 \mathrm{~Hz}, 1 \mathrm{H}), 7.71(\mathrm{~d}, J=$ $8.8 \mathrm{~Hz}, 1 \mathrm{H}), 7.42(\mathrm{dt}, J=7.7,1.6 \mathrm{~Hz}, 1 \mathrm{H}), 7.39-7.35(\mathrm{~m}, 2 \mathrm{H}), 7.27(\mathrm{~d}, J=2.3 \mathrm{~Hz}, 1 \mathrm{H}), 7.22(\mathrm{~d}, J$ $=5.4 \mathrm{~Hz}, 1 \mathrm{H}), 7.08(\mathrm{dd}, J=8.9,2.4 \mathrm{~Hz}, 1 \mathrm{H}), 5.72(\mathrm{dt}, J=3.5,1.8 \mathrm{~Hz}, 1 \mathrm{H}), 4.33(\mathrm{t}, J=6.6 \mathrm{~Hz}, 2 \mathrm{H})$, 3.85-3.74 (m, 2H), 3.49 (q, J = 6.9 Hz, 1H), 3.36-3.26 (m, 2H), 2.17-2.08 (m, 2H), 1.80-1.72 (m, $2 \mathrm{H}), 1.54-1.41(\mathrm{~m}, 5 \mathrm{H}), 0.98(\mathrm{t}, J=7.4 \mathrm{~Hz}, 3 \mathrm{H})$.

${ }^{13} \mathrm{C}$ NMR $\left(\mathrm{CDCl}_{3}, 101 \mathrm{MHz}\right): \delta$ 167.0, 149.0, 145.4, 140.9, 139.8, 132.2, 131.1, 130.8, 128.9, 128.5, 127.6, 127.0, 123.8, 122.8, 119.1, 116.1, 109.1, 65.0, 49.5, 47.1, 45.7, 30.9, 28.2, 19.6, 19.4, 13.9. IR (Diamond-ATR, neat) $\widetilde{\boldsymbol{v}}_{\max }:$ 2959, 2871, 1712, 1664, 1598, 1441, 1277, 1089, 818.

Specific Rotation $[\alpha]^{23}$ : $-212.3\left(c=1.0, \mathrm{CHCl}_{3}\right)$.

HRMS (DART) m/z: [M+H] calcd. for $\mathrm{C}_{26} \mathrm{H}_{30} \mathrm{NO}_{2} \mathrm{~S}^{+}:$420.1992. Found: 420.1993.

Chiral SFC: Chiralcel OJ-H $\left(\mathrm{scCO}_{2} / \mathrm{IPA}=95 / 5\right.$ to $60 / 40$ over $10 \mathrm{~min}$, then holding at 60:40 for 10 $\min , 2.5 \mathrm{~mL} / \mathrm{min}, 210-400 \mathrm{~nm}, 45^{\circ} \mathrm{C}$ ), $12.42 \mathrm{~min}$ (minor) and $13.66 \mathrm{~min}$ (major).

\section{$(S, E)-3-(2-m e t h y l-3-(0-t o l y l) b u t-1-e n-1-y l) f u r a n(3 h)$}<smiles>C/C(=C\c1ccoc1)C(C)C</smiles>

$3 \mathrm{~h}$

Prepared according to General Procedure C using 2-methylstyrene (59 mg, $0.50 \mathrm{mmol}, 1.0$ equiv) and 1-(furan-3-yl)prop-1-en-2-yl trifluoromethansulfonate (SI-2v) (190 mg, $0.75 \mathrm{mmol}, 1.5$ equiv). The residue was purified by flash column chromatography on silica (100 $\mathrm{g} \mathrm{SiO}_{2}$, hexane) to yield $3 \mathrm{~h}$ ( $1^{\text {st }}$ run: $82 \mathrm{mg}, 72 \%, 95: 5 \mathrm{er} ; 2^{\text {nd }}$ run: $\left.90 \mathrm{mg}, 80 \%, 95: 5 \mathrm{er}\right)$ as an orange oil.

Note: Although, $3 \mathrm{~h}$ was isolated isomerically pure, gradual $E: Z$ isomerization was observed when stored on the benchtop exposed to ambient light over ca. $48 \mathrm{~h}$. After $48 \mathrm{~h}$, a 12:1 E:Z ratio was observed, as determined by ${ }^{1} \mathrm{H}$ NMR.

${ }^{1} \mathrm{H}$ NMR $\left(\mathrm{CDCl}_{3}, 500 \mathrm{MHz}\right): \delta 7.43(\mathrm{~s}, 1 \mathrm{H}), 7.40(\mathrm{~s}, 1 \mathrm{H}), 7.24-7.12(\mathrm{~m}, 4 \mathrm{H}), 6.46(\mathrm{~s}, 1 \mathrm{H}), 6.10(\mathrm{~s}$, $1 \mathrm{H}), 3.74(\mathrm{q}, J=6.8 \mathrm{~Hz}, 1 \mathrm{H}), 2.37(\mathrm{~s}, 3 \mathrm{H}), 1.76(\mathrm{~s}, 3 \mathrm{H}), 1.43(\mathrm{dt}, J=7.0,1.5 \mathrm{~Hz}, 3 \mathrm{H})$.

${ }^{13} \mathrm{C} \mathrm{NMR}\left(\mathrm{CDCl}_{3}, 126 \mathrm{MHz}\right): \delta 143.1,142.5,141.4,140.4,136.4,130.5,126.7,126.2,126.2,123.3$, 114.8, 111.4, 44.3, 19.7, 19.7, 18.3.

IR (Diamond-ATR, neat) $\widetilde{v}_{\text {max }}: 2966,2873,1761,1488,1371,1028,831,701$.

Specific Rotation $[\alpha]^{23}{ }_{D}:-12.7\left(c=1.0, \mathrm{CHCl}_{3}\right)$.

HRMS (DART) m/z: [M+H] $]^{+}$calcd. for $\mathrm{C}_{16} \mathrm{H}_{19} \mathrm{O}^{+}: 227.1430$. Found: 227.1431.

Chiral SFC: Chiralcel AD-H ( $\mathrm{scCO}_{2} / \mathrm{IPA}=95 / 5$ to $85 / 15$ over $8 \mathrm{~min}, 2.5 \mathrm{~mL} / \mathrm{min}, 210-400 \mathrm{~nm}, 45$

$\left.{ }^{\circ} \mathrm{C}\right), 2.08 \mathrm{~min}$ (major) and $2.21 \mathrm{~min}$ (minor).

(S)-4-(3-(3-(4-fluorophenyl)but-3-en-2-yl)phenyl)thiomorpholine (3i)<smiles>C=C(c1ccc(F)cc1)[C@H](C)c1cccc(N2CCSCC2)c1</smiles> 
Prepared according to General Procedure C using 4-(3-vinylphenyl)thiomorpholine (SI-5j) (103 $\mathrm{mg}, 0.500 \mathrm{mmol}, 1.0$ equiv), 1-(4-fluorophenyl)vinyl-4-methylbenzenesulfonate (SI-2d) (220 mg, $0.75 \mathrm{mmol}, 1.5$ equiv). The residue was purified by automated reversed-phase flash column chromatography according to General Procedure D (40 g C18, gradient elution: $5 \% \mathrm{MeCN}$ in water $\left(0.1 \%\right.$ TFA) to $80 \% \mathrm{MeCN}$ in water $(0.1 \%$ TFA $)$ ) to yield $3 \mathbf{i}$ ( $1^{\text {st }}$ run: $65 \mathrm{mg}, 40 \%, 94: 6 \mathrm{er} ; 2^{\text {nd }}$ run: $77 \mathrm{mg}, 49 \%, 94: 6 \mathrm{er})$ as an orange oil.

${ }^{1} \mathrm{H}$ NMR $\left(\mathrm{CDCl}_{3}, 500 \mathrm{MHz}\right): \delta 7.25-7.19(\mathrm{~m}, 2 \mathrm{H}), 7.15(\mathrm{t}, J=8.0 \mathrm{~Hz}, 1 \mathrm{H}), 6.90(\mathrm{t}, J=8.7 \mathrm{~Hz}, 2 \mathrm{H})$, $6.74(\mathrm{~s}, 2 \mathrm{H}), 6.72-6.66(\mathrm{~m}, 1 \mathrm{H}), 5.35(\mathrm{~s}, 1 \mathrm{H}), 5.17(\mathrm{~s}, 1 \mathrm{H}), 3.90(\mathrm{q}, J=7.0 \mathrm{~Hz}, 1 \mathrm{H}), 3.50-3.43(\mathrm{~m}$, $4 \mathrm{H}), 2.78-2.69(\mathrm{~m}, 4 \mathrm{H}), 1.45(\mathrm{~d}, J=7.0 \mathrm{~Hz}, 3 \mathrm{H})$.

${ }^{13} \mathrm{C} \mathrm{NMR}\left(\mathrm{CDCl}_{3}, 126 \mathrm{MHz}\right): \delta=162.0(\mathrm{~d}, J=246.0 \mathrm{~Hz}), 151.7,146.1,138.4,129.3,128.4(\mathrm{~d}, \mathrm{~J}=$ 8.3 Hz), 127.6 (d, $J=30.5 \mathrm{~Hz}), 119.6,117.0,115.2,115.0$ (d, $J=21.2 \mathrm{~Hz}), 113.2,52.5,44.7,27.0$, 21.8.

${ }^{19} \mathrm{~F}$ NMR $\left(\mathrm{CDCl}_{3}, 471 \mathrm{MHz}\right): \delta-115.69$.

IR (Diamond-ATR, neat) $\widetilde{\boldsymbol{v}}_{\max }: 2963,2908,2816,1598,1507,1487,1380,838,781,700$.

Specific Rotation $[\alpha]^{23}{ }_{\mathrm{D}}:-28.9\left(c=1.0, \mathrm{CHCl}_{3}\right)$.

HRMS (DART) m/z: [M+H] ${ }^{+}$calcd. for $\mathrm{C}_{20} \mathrm{H}_{23} \mathrm{FNS}^{+}:$328.1530. Found: 328.1531.

Chiral SFC: Chiralcel OJ-H ( $\mathrm{scCO}_{2} / \mathrm{IPA}=95 / 5$ to $80 / 20$ over $15 \mathrm{~min}, 2.5 \mathrm{~mL} / \mathrm{min}, 210-400 \mathrm{~nm}, 45$

$\left.{ }^{\circ} \mathrm{C}\right), 7.67 \mathrm{~min}$ (minor) and 8.25 min (major).

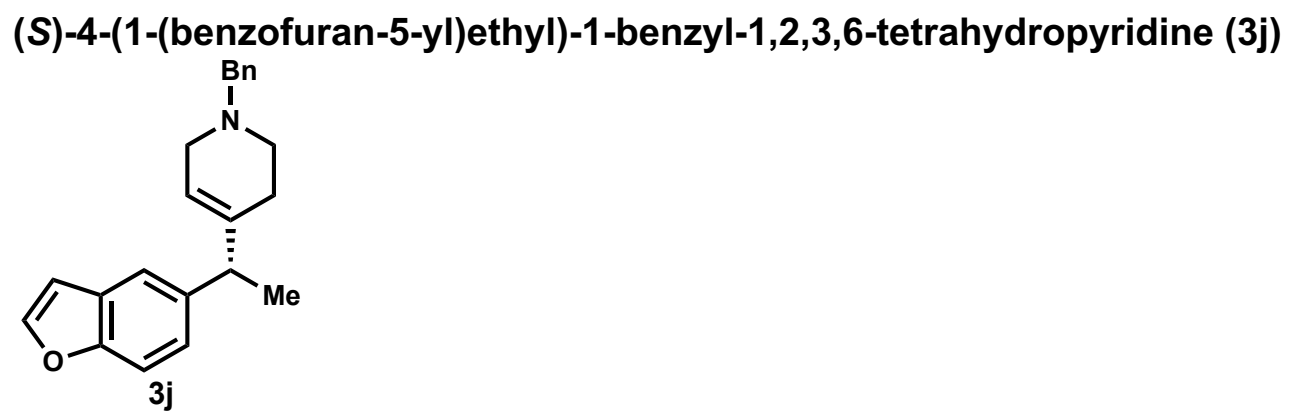

Prepared according to a modified General Procedure C using 5-vinylbenzofuran (SI-5a) (72 mg, $0.50 \mathrm{mmol}, 1.0$ equiv), (1-benzyl-1,2,3,6-tetrahydropyridin-4-yl trifluoromethanesulfonate (SI-2e) (240 mg, $0.75 \mathrm{mmol}, 1.5$ equiv) and $\mathrm{Pd}($ cinnamyl)(Cl)(dppbz) $(7 \mathrm{mg}, 10 \mu \mathrm{mol}, 2.0 \mathrm{~mol} \%)$. The residue was purified by automated reversed-phase flash column chromatography according to General Procedure D (40 g C18, gradient elution: $5 \% \mathrm{MeCN}$ in water $(0.1 \%$ TFA) to $75 \% \mathrm{MeCN}$ in water $(0.1 \%$ TFA $)$ ) to yield $3 \mathbf{j}$ ( $1^{\text {st }}$ run: $83 \mathrm{mg}, 52 \%, 95: 5 \mathrm{er} ; 2^{\text {nd }}$ run: $86 \mathrm{mg}, 54 \%, 96: 4$ er) as a yellow oil.

${ }^{1} \mathrm{H}$ NMR $\left(\mathrm{CDCl}_{3}, 400 \mathrm{MHz}\right): \delta 7.59(\mathrm{~d}, J=2.2 \mathrm{~Hz}, 1 \mathrm{H}), 7.42-7.38(\mathrm{~m}, 2 \mathrm{H}), 7.35-7.28(\mathrm{~m}, 4 \mathrm{H})$, $7.25-7.21(\mathrm{~m}, 1 \mathrm{H}), 7.13(\mathrm{dd}, J=8.6,1.8 \mathrm{~Hz}, 1 \mathrm{H}), 6.72(\mathrm{dd}, J=2.2,0.9 \mathrm{~Hz}, 1 \mathrm{H}), 5.56 \mathrm{(td}, J=3.4$, $1.6 \mathrm{~Hz}, 1 \mathrm{H}), 3.60(\mathrm{~s}, 2 \mathrm{H}), 3.42(\mathrm{q}, J=7.4 \mathrm{~Hz}, 1 \mathrm{H}), 3.08(\mathrm{q}, J=16.1 \mathrm{~Hz}, 2 \mathrm{H}), 2.55$ (dt, $J=10.9,5.4$ $\mathrm{Hz}, 1 \mathrm{H}), 2.43(\mathrm{dt}, J=11.4,5.9 \mathrm{~Hz}, 1 \mathrm{H}), 2.01-1.94(\mathrm{~m}, 2 \mathrm{H}), 1.39(\mathrm{~d}, J=7.1 \mathrm{~Hz}, 3 \mathrm{H})$.

${ }^{13} \mathrm{C}$ NMR $\left(\mathrm{CDCl}_{3}, 101 \mathrm{MHz}\right): \delta 153.8,145.2,140.3,140.0,138.3,129.3,128.3,127.5,127.1,124.3$, 119.7, 118.7, 111.1, 106.7, 62.8, 53.1, 50.0, 45.6, 28.2, 20.3.

IR (Diamond-ATR, neat) $\widetilde{\boldsymbol{v}}_{\max }: 2962,2798,1662,1466,1363,1261,1127,1029,880$.

Specific Rotation $[\alpha]^{23}{ }_{D}:-18.1\left(c=1.0, \mathrm{CHCl}_{3}\right)$.

HRMS (DART) m/z: [M+H] ${ }^{+}$calcd. for $\mathrm{C}_{22} \mathrm{H}_{24} \mathrm{NO}^{+}:$318.1852. Found: 318.1851.

Chiral SFC: Chiralcel AD-H $\left(\mathrm{scCO}_{2} / \mathrm{MeOH} / \mathrm{Et}_{2} \mathrm{NH}=95 / 4.95 / 0.05\right.$ to 80/19.80/0.2 over 8 min, 2.5 $\mathrm{mL} / \mathrm{min}, 210-400 \mathrm{~nm}, 45^{\circ} \mathrm{C}$ ), $6.07 \mathrm{~min}$ (minor) and $6.22 \mathrm{~min}$ (major). 
Supporting Information

(S,E)-5-(3-([1,1'-biphenyl]-4-yl)-2-methylbut-1-en-1-yl)-1-cyclopentyl-1H-pyrrolo[2,3b]pyridine (3k)<smiles>C/C(=C\c1cnc2c(ccn2C2CCCC2)c1)[C@@H](C)c1ccc(-c2ccccc2)cc1</smiles>

Prepared according to General Procedure C using 4-vinyl-biphenyl (1b) (90 mg, 0.50 mmol, 1.0 equiv) and (E)-1-(1-cyclopentyl-1H-pyrrolo[2,3-b]pyridin-5-yl)prop-1-en-2-yl trifluoromethanesulfonate (SI-2u) $(280 \mathrm{mg}, 0.75 \mathrm{mmol}, 1.5$ equiv). The residue was purified by automated reversed-phase flash column chromatography according to General Procedure D (40 g C18, gradient elution: $5 \% \mathrm{MeCN}$ in water $(0.1 \%$ TFA) to $100 \% \mathrm{MeCN})$ to yield $3 \mathbf{k}\left(1^{\text {st }} \mathrm{run}: 97 \mathrm{mg}\right.$, $48 \%, 97: 3 \mathrm{er} ; 2^{\text {nd }}$ run: $111 \mathrm{mg}, 55 \%, 98: 2 \mathrm{er}$ ) as an orange oil.

${ }^{1} \mathrm{H}$ NMR $\left(\mathrm{CDCl}_{3}, 400 \mathrm{MHz}\right): \delta 8.30(\mathrm{~d}, J=2.0 \mathrm{~Hz}, 1 \mathrm{H}), 7.84(\mathrm{~d}, J=2.0 \mathrm{~Hz}, 1 \mathrm{H}), 7.64-7.60(\mathrm{~m}, 2 \mathrm{H})$, 7.59-7.56 (m, 2H), 7.47-7.38 (m, 4H), $7.34(\mathrm{tt}, J=7.4,1.0 \mathrm{~Hz}, 1 \mathrm{H}), 7.29(\mathrm{~d}, J=3.6 \mathrm{~Hz}, 1 \mathrm{H}), 6.63$ $(\mathrm{s}, 1 \mathrm{H}), 6.45(\mathrm{~d}, J=3.6 \mathrm{~Hz}, 1 \mathrm{H}), 5.36-5.27(\mathrm{~m}, 1 \mathrm{H}), 3.68(\mathrm{q}, J=7.1 \mathrm{~Hz}, 1 \mathrm{H}), 2.33-2.21(\mathrm{~m}, 2 \mathrm{H})$, $1.97-1.86(\mathrm{~m}, 4 \mathrm{H}), 1.84-1.75(\mathrm{~m}, 2 \mathrm{H}), 1.80(\mathrm{~d}, J=1.3 \mathrm{~Hz}, 3 \mathrm{H}), 1.57(\mathrm{~d}, J=7.1 \mathrm{~Hz}, 3 \mathrm{H})$.

${ }^{13} \mathrm{C} \mathrm{NMR}\left(\mathrm{CDCl}_{3}, 101 \mathrm{MHz}\right): \delta$ 146.4, 144.3, 144.0, 142.0, 141.2, 139.2, 128.8, 128.6, 128.1, 127.2, 127.2, 127.1, 126.4, 125.2, 122.6, 120.3, 99.6, 55.0, 48.3, 33.0, 24.2, 19.8, 16.7.

IR (Diamond-ATR, neat) $\widetilde{v}_{\text {max }}: 2961,2961,1598,1402,1310,1174,906,837$.

Specific Rotation $[\alpha]^{23}$ : $+6.3\left(c=1.0, \mathrm{CHCl}_{3}\right)$.

HRMS (DART) m/z: [M+H] ${ }^{+}$calcd. for $\mathrm{C}_{29} \mathrm{H}_{31} \mathrm{~N}_{2}{ }^{+}: 407.2482$. Found: 407.2480.

Chiral SFC: Chiralcel CEL2 ( $\mathrm{scCO}_{2} / \mathrm{MeOH} / \mathrm{Et}_{2} \mathrm{NH}=95 / 4.95 / 0.05$ to 65/34.65/0.35 over 8 min, 2.5 $\mathrm{mL} / \mathrm{min}, 210-400 \mathrm{~nm}, 45^{\circ} \mathrm{C}$ ), $2.89 \mathrm{~min}$ (major) and $3.11 \mathrm{~min}$ (minor).

Melting Point $\left({ }^{\circ} \mathrm{C}\right): 89-92$.

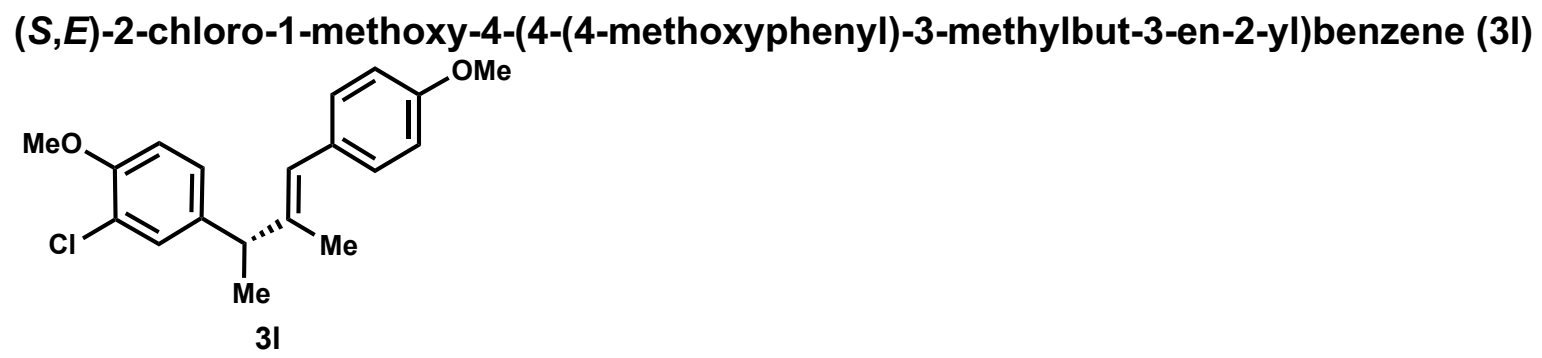

Prepared according to General Procedure C using 2-chloro-1-methoxy-4-vinylbenzene (SI-5b) (84 mg, $0.50 \mathrm{mmol}, \quad 1.0$ equiv) and (E)-1-(4-methoxyphenyl)prop-1-en-2-yl trifluoromethanesulfonate (SI-2r) $(220 \mathrm{mg}, 0.75 \mathrm{mmol}, 1.5$ equiv). The residue was purified by flash column chromatography on silica gel (gradient elution: hexane to $2 \%$ EtOAc in hexane) to yield $\mathbf{3 I}$ ( $1^{\text {st }}$ run: $116 \mathrm{mg}, 73 \%, 98: 2 \mathrm{er} ; 2^{\text {nd }}$ run: $111 \mathrm{mg}, 70 \%, 98: 2 \mathrm{er}$ ) as a yellow oil.

${ }^{1} \mathrm{H}$ NMR $\left(\mathrm{CDCl}_{3}, 400 \mathrm{MHz}\right): \delta 7.28(\mathrm{~d}, J=2.2 \mathrm{~Hz}, 1 \mathrm{H}), 7.22(\mathrm{~d}, J=8.7 \mathrm{~Hz}, 2 \mathrm{H}), 7.13(\mathrm{dd}, J=8.5$, $2.2 \mathrm{~Hz}, 1 \mathrm{H}), 6.87$ (dd, J = 8.7, 2.3 Hz, 3H), 6.42-6.37 (m, 1H), $3.89(\mathrm{~s}, 3 \mathrm{H}), 3.82(\mathrm{~s}, 3 \mathrm{H}), 3.49$ (q, $J=7.1 \mathrm{~Hz}, 1 \mathrm{H}), 1.69(\mathrm{~d}, J=1.4 \mathrm{~Hz}, 3 \mathrm{H}), 1.44(\mathrm{~d}, J=7.0 \mathrm{~Hz}, 3 \mathrm{H})$.

${ }^{13} \mathrm{C}$ NMR $\left(\mathrm{CDCl}_{3}, 126 \mathrm{MHz}\right): \delta 158.0,153.4,140.5,138.6,131.0,130.2,129.4,126.8,124.5$, 122.3, 113.6, 112.1, 56.3, 55.4, 47.6, 19.7, 16.5 .

IR (Diamond-ATR, neat) $\widetilde{v}_{\text {max: }}$ 2963, 2930, 2823, 1607, 1501, 1458, 1282, 1249, 1173, 1064 , 1024, 878, 789.

Specific Rotation $[\alpha]^{23}{ }_{\mathrm{D}}:+27.0\left(c=1.0, \mathrm{CHCl}_{3}\right)$. 
HRMS (DART) m/z: [M+H] $]^{+}$calcd. for $\mathrm{C}_{19} \mathrm{H}_{22} \mathrm{ClO}_{2}{ }^{+}:$317.1303. Found: 317.1307.

Chiral SFC: Chiralcel OJ-H $\left(\mathrm{scCO}_{2} / \mathrm{IPA}=98 / 2\right.$ to $80 / 20$ over $15 \mathrm{~min}, 2.5 \mathrm{~mL} / \mathrm{min}, 210-400 \mathrm{~nm}$, $\left.45^{\circ} \mathrm{C}\right), 11.74 \mathrm{~min}$ (minor) and 12.26 min (major).

\section{(S)-(4-(4,4-diphenylbut-3-en-2-yl)phenyl)(methyl)sulfane (3m)}<smiles>Cc1ccc(C(C=C(c2ccccc2)c2ccccc2)c2ccccc2)cc1</smiles>

Prepared according to a modified General Procedure C using 4-thiomethylstyrene (SI-5c) (75 mg, $0.50 \mathrm{mmol}, 1.0$ equiv), 1,1-diphenylprop-1-en-2-yl (4-methylbenzenesulfonate) (SI-2f) (260 mg, $0.75 \mathrm{mmol}, 1.5$ equiv) and (S)-DTBM-MeO-BIPHEP (L2) $(40.3 \mathrm{mg}, 35 \mu \mathrm{mol}, 7.0 \mathrm{~mol} \%$ ). The residue was purified by automated flash column chromatography on silica $\left(40 \mathrm{~g} \mathrm{SiO}_{2}\right.$, gradient elution: hexane to $10 \% \mathrm{CH}_{2} \mathrm{Cl}_{2}$ in hexane) to yield $3 \mathrm{~m}$ ( $1^{\text {st }}$ run: $92 \mathrm{mg}, 56 \%, 95: 5 \mathrm{er} ; 2^{\text {nd }}$ run: 110 $\mathrm{mg}, 66 \%, 96: 4 \mathrm{er})$ as a colorless solid.

${ }^{1} \mathrm{H}$ NMR yield was determined using a modified General Procedure $\mathbf{C}$ using 4-thiomethylstyrene (SI-5j) (75 mg, $0.50 \mathrm{mmol}, 1.0$ equiv), 1,1-diphenylprop-1-en-2-yl (4-methylbenzenesulfonate) (SI-

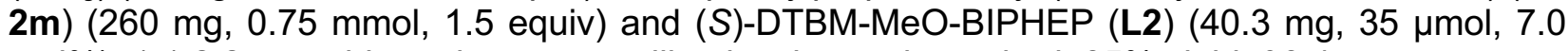
mol\%). 1,1,2,2-tetrachloroethane was utilized as internal standard: 85\% yield, 96:4 er.

${ }^{1} \mathbf{H}$ NMR $\left(\mathrm{CDCl}_{3}, 500 \mathrm{MHz}\right): \delta$ 7.42-7.38 (m, 2H), 7.36-7.33 (m, 1H), 7.28-7.18 (m, 9H), $7.14(\mathrm{~d}$, $J=8.1 \mathrm{~Hz}, 2 \mathrm{H}), 6.19(\mathrm{~d}, J=10.2 \mathrm{~Hz}, 1 \mathrm{H}), 3.62-3.54(\mathrm{~m}, 1 \mathrm{H}), 2.48(\mathrm{~m}, 3 \mathrm{H}), 1.38(\mathrm{~d}, J=6.9 \mathrm{~Hz}$, $3 \mathrm{H})$.

${ }^{13} \mathrm{C}$ NMR $\left(\mathrm{CDCl}_{3}, 126 \mathrm{MHz}\right): \delta 143.5,142.4,140.4,140.2,135.7,134.0,129.9,128.4,128.2$, 127.6, 127.4, 127.3, 127.2, 127.2, 38.9, 22.4, 16.4 .

IR (Diamond-ATR, neat) $\widetilde{v}_{\text {max }}:$ 3052, 2963, 2920, 1494, 1443, 1012.

Specific Rotation $[\alpha]^{23}$ : $+123.6\left(c=1.0, \mathrm{CHCl}_{3}\right)$.

HRMS (DART) m/z: $[\mathrm{M}+\mathrm{H}]^{+}$calcd. for $\mathrm{C}_{23} \mathrm{H}_{23} \mathrm{~S}^{+}: 331.1515$. Found: 331.1510.

Chiral SFC: Chiralcel OD-H ( $\mathrm{scCO}_{2} / \mathrm{IPA}=95 / 5$ to $85 / 15$ over $8 \mathrm{~min}, 2.5 \mathrm{~mL} / \mathrm{min}, 210-400 \mathrm{~nm}, 45$ $\left.{ }^{\circ} \mathrm{C}\right), 6.95 \mathrm{~min}$ (major) and $7.15 \mathrm{~min}$ (minor).

Melting Point $\left({ }^{\circ} \mathrm{C}\right): 73-75$.

(S)-9-ethyl-3-(1-(3,4,5,6-tetrahydro-[1,1'-biphenyl]-2-yl)ethyl)-9H-carbazole (3n)<smiles>CCn1c2ccccc2c2cc([C@H](C)C3=C(c4ccccc4)CCCC3)ccc21</smiles>

Prepared according to General Procedure C using 9-ethyl-3-vinyl-9H-carbazole (SI-5d) (110 mg, 0.50 mmol, 1.0 equiv) and 3,4,5,6-tetrahydro-[1,1'-biphenyl]-2-yl trifluoromethanesulfonate (SI-2g) (230 $\mathrm{mg}, 0.75 \mathrm{mmol}, 1.5$ equiv). The residue was purified by flash column chromatography on silica gel (gradient elution: hexane to $5 \% \mathrm{CH}_{2} \mathrm{Cl}_{2}$ in hexane) to yield a mixture of $3 \mathrm{n}$ and the linear byproduct ( $1^{\text {st }}$ run: $81 \mathrm{mg}, 43 \%, 97: 3 \mathrm{er}, 92: 8$ branched:linear; $2^{\text {nd }}$ run: $80 \mathrm{mg}, 42 \%, 98: 2 \mathrm{er}, 95: 5$ 
branched:linear) as a colorless solid. An analytically pure sample of the linear product was isolated by preparatory thin layer chromatography $\left(5 \% \mathrm{CH}_{2} \mathrm{Cl}_{2}\right.$ in hexane).

${ }^{1} \mathrm{H}$ NMR yield was determined using a modified General Procedure C with 9-ethyl-3-vinyl-9Hcarbazole (SI-5d) (110 mg, $0.50 \mathrm{mmol}, 1.0$ equiv) and 3,4,5,6-tetrahydro-[1,1'-biphenyl]-2-yl trifluoromethanesulfonate (SI-2g) (230 mg, 0.75 mmol, 1.5 equiv). 1,1,2,2-tetrachloroethane was utilized as internal standard: 59\% yield, 95:5 er, 88:12 branched:linear.

${ }^{1} \mathrm{H}$ NMR $\left(\mathrm{CDCl}_{3}, 400 \mathrm{MHz}\right): \delta 8.08(\mathrm{~d}, J=7.7 \mathrm{~Hz}, 1 \mathrm{H}), 7.86(\mathrm{~s}, 1 \mathrm{H}), 7.44(\mathrm{td}, J=7.5,6.9,1.2 \mathrm{~Hz}$, $1 \mathrm{H}), 7.41-7.35(\mathrm{~m}, 3 \mathrm{H}), 7.31-7.25(\mathrm{~m}, 5 \mathrm{H}), 7.23-7.18(\mathrm{~m}, 1 \mathrm{H}), 4.34(\mathrm{q}, J=7.2 \mathrm{~Hz}, 2 \mathrm{H}), 3.99(\mathrm{q}, J$ $=7.1 \mathrm{~Hz}, 1 \mathrm{H}), 2.41-2.18(\mathrm{~m}, 2 \mathrm{H}), 2.14-2.04(\mathrm{~m}, 1 \mathrm{H}), 1.79-1.56(\mathrm{~m}, 5 \mathrm{H}), 1.47-1.39(\mathrm{~m}, 6 \mathrm{H})$.

${ }^{13} \mathrm{C} \mathrm{NMR}\left(\mathrm{CDCl}_{3}, 101 \mathrm{MHz}\right): \delta 145.1,140.3,138.5,137.4,135.6,133.0,128.5,128.4,126.2,125.9$, $125.4,123.1,122.7,120.4,118.6,118.6,108.5,108.0,40.4,37.7,33.1,23.6,23.6,23.2$, 18.2, 14.0.

IR (Diamond-ATR, neat) $\widetilde{v}_{\text {max: }}$ 2926, 2899, 1482, 1406, 1327, 1206, 1136, 1023, 884, 807.

Specific Rotation $[\alpha]^{23}$ : $+253.7\left(c=1.0, \mathrm{CHCl}_{3}\right)$.

HRMS (DART) m/z: [M+H] $]^{+}$calcd. for $\mathrm{C}_{28} \mathrm{H}_{30} \mathrm{~N}^{+}: 380.2373$. Found: 380.2372 .

Chiral SFC: Chiralcel AD-H $\left(\mathrm{scCO}_{2} / \mathrm{IPA}=95 / 5\right.$ to $80 / 20$ over $15 \mathrm{~min}, 2.5 \mathrm{~mL} / \mathrm{min}, 210-400 \mathrm{~nm}, 45$ $\left.{ }^{\circ} \mathrm{C}\right), 10.58 \mathrm{~min}$ (major) and $10.87 \mathrm{~min}$ (minor).

Melting Point $\left({ }^{\circ} \mathrm{C}\right): 88-90$.

\section{(S)-4-(1-(cyclohept-1-en-1-yl)ethyl)-1-(3-fluorophenyl)-1H-pyrazole (3o)}

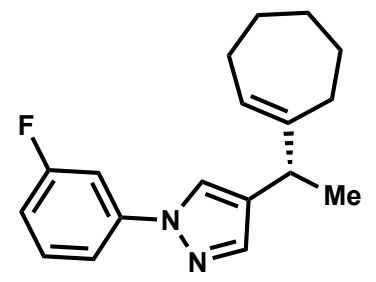

30

Prepared according to a modified General Procedure C using 1-(3-fluorophenyl)-4-vinyl-1Hpyrazole (SI-5e) $(94 \mathrm{mg}, 0.50 \mathrm{mmol}, 1.0$ equiv), cyclohept-1-en-1-yl trifluoromethanesulfonate (SI2h) $(180 \mathrm{mg}, 0.75 \mathrm{mmol}, 1.5$ equiv), Cul (2.9 mg, $15 \mu \mathrm{mol}, 3.0 \mathrm{~mol} \%)$, (S)-DTBM-SEGPHOS (L1) (20.6 mg, $18.0 \mu \mathrm{mol}, 3.5 \mathrm{~mol} \%)$, and $\mathrm{Pd}($ cinnamyl)(dppbz)(Cl) (10.6 mg, $15.0 \mu \mathrm{mol}, 3.0 \mathrm{~mol} \%$ ). The residue was purified by flash column chromatography on silica gel (gradient elution: hexane to $25 \% \mathrm{CH}_{2} \mathrm{Cl}_{2}$ in hexane) to yield 30 ( $1^{\text {st }}$ run: $117 \mathrm{mg}, 82 \%, 98: 2 \mathrm{er} ; 2^{\text {nd }}$ run: $118 \mathrm{mg}, 83 \%, 97: 3$ er) as a colorless oil.

Note: Significant depreciation in the conversion was noted if SI-5e was stored for extended periods (ca. one week). Therefore, SI-5e was employed immediately after purification in the olefin hydroalkenylation reaction.

${ }^{1} \mathrm{H}$ NMR $\left(\mathrm{CDCl}_{3}, 400 \mathrm{MHz}\right): \delta 7.65(\mathrm{~s}, 1 \mathrm{H}), 7.52(\mathrm{~s}, 1 \mathrm{H}), 7.47-7.42(\mathrm{~m}, 2 \mathrm{H}), 7.40-7.34(\mathrm{~m}, 1 \mathrm{H})$, 6.96-6.90 (m, 1H), $5.74(\mathrm{t}, J=6.5 \mathrm{~Hz}, 1 \mathrm{H}), 3.41(\mathrm{q}, J=7.1 \mathrm{~Hz}, 1 \mathrm{H}), 2.13(\mathrm{td}, J=6.9,3.4 \mathrm{~Hz}, 2 \mathrm{H})$, 2.05-2.00 (m, 2H), 1.75-1.68 (m, 2H), 1.51-1.44 (m, 2H), 1.42-1.36 (m, 2H), $1.34(\mathrm{~d}, J=7.1 \mathrm{~Hz}$, $3 \mathrm{H})$.

${ }^{13} \mathrm{C}$ NMR $\left(\mathrm{CDCl}_{3}, 101 \mathrm{MHz}\right): \delta 163.4(\mathrm{~d}, J=246.2 \mathrm{~Hz}), 147.7,141.8(\mathrm{~d}, \mathrm{~J}=10.3 \mathrm{~Hz}), 141.2,130.7$ $(\mathrm{d}, J=9.2 \mathrm{~Hz}), 128.6,126.4,124.5,113.9(\mathrm{~d}, J=3.1 \mathrm{~Hz}), 112.7(\mathrm{~d}, J=21.3 \mathrm{~Hz}), 106.4(\mathrm{~d}, J=26.3$ $\mathrm{Hz}), 39.3,32.9,30.3,28.5,27.6,27.4,19.5$.

${ }^{19} \mathrm{~F}$ NMR $\left(\mathrm{CDCl}_{3}, 376 \mathrm{MHz}\right): \delta-111.21$. 
IR (Diamond-ATR, neat) $\widetilde{v}_{\text {max: }}$ 2965, 2917, 2847, 1612, 1496, 1391, 1295, 1180, 1149, 968, 864, 770.

Specific Rotation $[\alpha]^{23}{ }_{\mathrm{D}}:+30.2\left(c=1.0, \mathrm{CHCl}_{3}\right)$.

EA calcd. for $\mathrm{C}_{18} \mathrm{H}_{21} \mathrm{FN}_{2}$ : C, 76.02; $\mathrm{H}, 7.44$ Found: $\mathrm{C}, 75.71 ; \mathrm{H}, 7.69$.

Chiral SFC: Chiralcel OJ-H $\left(\mathrm{scCO}_{2} / \mathrm{IPA}=95 / 5\right.$ to $80 / 20$ over $8 \mathrm{~min}, 2.5 \mathrm{~mL} / \mathrm{min}, 210-400 \mathrm{~nm}, 45$ $\left.{ }^{\circ} \mathrm{C}\right), 3.73 \mathrm{~min}$ (major) and $4.07 \mathrm{~min}$ (minor).

\section{(S)-5-(3-(benzyloxy)-1-(3,6-dihydro-2H-pyran-4-yl)propyl)-2-methoxypyridine (3p)}<smiles>COc1ccc(C(CCOCc2ccccc2)C2=CCOCC2)cn1</smiles>

Prepared according to General Procedure C using (E)-2-(3-(benzyloxy)prop-1-en-1-yl)-6methoxypyridine (SI-5m) (128 $\mathrm{mg}, 0.50 \mathrm{mmol}, 1.0$ equiv) and 3,6-dihydro-2H-pyran-4-yl trifluoromethanesulfonate (SI-20) $(170 \mathrm{mg}, 0.75 \mathrm{mmol}, 1.5$ equiv). The residue was purified by automated flash column chromatography on silica gel $\left(50 \mathrm{~g} \mathrm{SiO}_{2}\right.$, gradient elution: hexane to $10 \%$ EtOAc in hexane to $40 \%$ EtOAc in hexane) to yield $3 p$ ( $1^{\text {st }}$ run: $77 \mathrm{mg}, 50 \%, 96: 4$ er; $2^{\text {nd }}$ run: 78 $\mathrm{mg}, 51 \%, 95: 5 \mathrm{er}$ ) as a yellow oil.

${ }^{1} \mathrm{H}$ NMR $\left(\mathrm{CDCl}_{3}, 400 \mathrm{MHz}\right): \delta 7.98(\mathrm{~d}, J=2.5 \mathrm{~Hz}, 1 \mathrm{H}), 7.38(\mathrm{dd}, J=8.6,2.5 \mathrm{~Hz}, 1 \mathrm{H}), 7.35-7.28$ $(\mathrm{m}, 5 \mathrm{H}), 6.68(\mathrm{~d}, \mathrm{~J}=8.5 \mathrm{~Hz}, 1 \mathrm{H}), 5.61-5.57(\mathrm{~m}, 1 \mathrm{H}), 4.44(\mathrm{~s}, 2 \mathrm{H}), 4.15(\mathrm{~s}, 2 \mathrm{H}), 3.92(\mathrm{~s}, 3 \mathrm{H}), 3.74-$ $3.62(\mathrm{~m}, 2 \mathrm{H}), 3.47-3.40(\mathrm{~m}, 1 \mathrm{H}), 3.39-3.30(\mathrm{~m}, 2 \mathrm{H}), 2.17(\mathrm{dt}, J=13.6,6.8 \mathrm{~Hz}, 1 \mathrm{H}), 1.98-1.86(\mathrm{~m}$, $3 \mathrm{H})$.

${ }^{13} \mathrm{C}$ NMR $\left(\mathrm{CDCl}_{3}, 101 \mathrm{MHz}\right): \delta 163.2,146.2,138.5,138.4,137.5,130.7,128.5,127.9,127.8,120.7$, $110.9,73.2,68.0,65.6,64.5,53.6,45.0,32.4,27.1$.

IR (Diamond-ATR, neat) $\widetilde{v}_{\max }: 2925,2851,1604,1489,1392,1288,1076,1027,698$.

Specific Rotation $[\alpha]^{23}$ : $-24.2\left(c=1.0, \mathrm{CHCl}_{3}\right)$.

HRMS (DART) m/z: [M+H] ${ }^{+}$calcd. for $\mathrm{C}_{21} \mathrm{H}_{26} \mathrm{NO}_{3}{ }^{+}: 340.1907$. Found: 340.1905 .

Chiral SFC: Chiralcel AD-H $\left(\mathrm{scCO}_{2} / \mathrm{MeOH}=95 / 5\right.$ to $60 / 40$ over $8 \mathrm{~min}, 2.5 \mathrm{~mL} / \mathrm{min}, 210-400 \mathrm{~nm}$, $45^{\circ} \mathrm{C}$ ), $4.26 \mathrm{~min}$ (minor) and $4.40 \mathrm{~min}$ (major).

\section{(S)-2-(4-(cyclohex-1-en-1-yl)-4-phenylbutoxy)benzo[d]thiazole (3q)

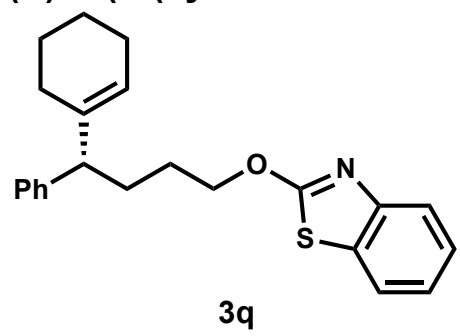

Prepared according to a modified General Procedure C using (E)-2-((4-phenylbut-3-en-1yl)oxy)benzo[d]thiazole (SI-5n) (141 mg, $0.500 \mathrm{mmol}, 1.0$ equiv), cyclohex-1-en-1-yl trifluoromethanesulfonate (2a) (170 mg, $0.75 \mathrm{mmol}, 1.5$ equiv), Cul (2.9 mg, $15 \mu \mathrm{mol}, 3.0 \mathrm{~mol} \%$ ), (S)-DTBM-SEGPHOS (L1) (20.6 mg, $18.0 \mu \mathrm{mol}, 3.5 \mathrm{~mol} \%)$, and Pd(cinnamyl)(dppbz)(Cl) (10.6 $\mathrm{mg}, 15.0 \mu \mathrm{mol}, 3.0 \mathrm{~mol} \%)$. The residue was purified by automated flash column chromatography on silica gel (50 $\mathrm{g} \mathrm{SiO}_{2}$, gradient elution: hexane to 5\% EtOAc in hexane) to yield $\mathbf{3 q}$ ( $1^{\text {st }}$ run: 153 $\mathrm{mg}, 81 \%, 99: 1 \mathrm{er} ; 2^{\text {nd }}$ run: $159 \mathrm{mg}, 84 \%, 99: 1 \mathrm{er}$ ) as a colorless solid. 
${ }^{1} \mathrm{H}$ NMR $\left(\mathrm{CDCl}_{3}, 400 \mathrm{MHz}\right): \delta 7.42(\mathrm{~d}, J=7.7 \mathrm{~Hz}, 1 \mathrm{H}), 7.31-7.27(\mathrm{~m}, 3 \mathrm{H}), 7.21-7.12(\mathrm{~m}, 4 \mathrm{H}), 6.94$ $(\mathrm{d}, J=8.1 \mathrm{~Hz}, 1 \mathrm{H}), 5.63(\mathrm{~s}, 1 \mathrm{H}), 4.01-3.88(\mathrm{~m}, 2 \mathrm{H}), 3.14(\mathrm{t}, J=7.5 \mathrm{~Hz}, 1 \mathrm{H}), 2.09-2.01(\mathrm{~m}, 2 \mathrm{H})$, $1.98-1.88(\mathrm{~m}, 1 \mathrm{H}), 1.87-1.60(\mathrm{~m}, 5 \mathrm{H}), 1.56-1.45(\mathrm{~m} .4 \mathrm{H})$.

${ }^{13} \mathrm{C}$ NMR $\left(\mathrm{CDCl}_{3}, 101 \mathrm{MHz}\right): \delta 169.9,143.8,139.7,137.2,128.3,127.9,126.3,126.2,123.0,122.9$, $122.7,122.0,110.7,52.5,42.8,29.6,26.5,25.9,25.4,23.0,22.6$.

IR (Diamond-ATR, neat) $\widetilde{v}_{\text {max: }}$ 3023, 2924, 2855, 2834, 1671, 1590, 1492, 1323, 1097, 700.

Specific Rotation $[\alpha]^{23}$ : $-4.4\left(c=1.0, \mathrm{CHCl}_{3}\right)$.

EA calcd. for $\mathrm{C}_{23} \mathrm{H}_{25} \mathrm{NOS}$ : C, 75.99; $\mathrm{H}, 6.93$. Found: $\mathrm{C}, 75.70 ; \mathrm{H}, 7.06$.

Chiral SFC: Chiralcel OJ-H $\left(\mathrm{scCO}_{2} / \mathrm{IPA}=95 / 5\right.$ to $60 / 40$ over $8 \mathrm{~min}, 2.5 \mathrm{~mL} / \mathrm{min}, 210-400 \mathrm{~nm}, 45$

$\left.{ }^{\circ} \mathrm{C}\right), 5.80 \mathrm{~min}$ (minor) and $6.01 \mathrm{~min}$ (major).

Melting Point $\left({ }^{\circ} \mathrm{C}\right): 58-60$.

(S)-8-(3-methyl-1-(4-(trifluoromethoxy)phenyl)butyl)-1,4-dioxaspiro[4.5]dec-7-ene (3r)<smiles>CC(C)C[C@H](C1=CCC2(CC1)OCCO2)c1ccc(OC(F)(F)F)cc1</smiles>

Prepared according to a modified General Procedure C using (Z)-1-(3-methylbut-1-en-1-yl)-4(trifluoromethoxy)benzene (SI-5o) (115 mg, $0.500 \mathrm{mmol}, 1.0$ equiv), 1,4-dioxaspiro[4.5]dec-7-en8 -yl trifluoromethanesulfonate (SI-2i) $(220 \mathrm{mg}, 0.75 \mathrm{mmol}, 1.5$ equiv) and (S)-DTBM-MeO-BIPHEP (L2) $(40.3 \mathrm{mg}, 35 \mu \mathrm{mol}, 7.0 \mathrm{~mol} \%)$. The residue was purified by automated reversed-phase flash column chromatography according to General Procedure D (40 g C18, gradient elution: $5 \%$ MeCN in water to $100 \% \mathrm{MeCN}$ ) to yield $3 \mathrm{r}$ ( $1^{\text {st }}$ run: $65 \mathrm{mg}, 35 \%, 94: 6 \mathrm{er} ; 2^{\text {nd }}$ run: $71 \mathrm{mg}, 38 \%, 94: 6$ er) as a colorless oil.

${ }^{1} \mathrm{H}$ NMR $\left(\mathrm{CDCl}_{3}, 500 \mathrm{MHz}\right): \delta 7.21-7.18(\mathrm{~m}, 2 \mathrm{H}), 7.11(\mathrm{~d}, \mathrm{~J}=8.4 \mathrm{~Hz}, 2 \mathrm{H}), 5.52-5.48(\mathrm{~m}, 1 \mathrm{H})$, 4.00-3.91 (m, 4H), 3.29 (t, $J=7.8 \mathrm{~Hz}, 1 \mathrm{H}), 2.33-2.29(\mathrm{~m}, 2 \mathrm{H}), 2.03-1.97(\mathrm{~m}, 2 \mathrm{H}), 1.68-1.54(\mathrm{~m}$, $4 \mathrm{H}), 1.43-1.34(\mathrm{~m}, 1 \mathrm{H}), 0.89(\mathrm{~d}, J=6.6 \mathrm{~Hz}, 3 \mathrm{H}), 0.85(\mathrm{~d}, J=6.6 \mathrm{~Hz}, 3 \mathrm{H})$.

${ }^{13} \mathrm{C}$ NMR $\left(\mathrm{CDCl}_{3}, 126 \mathrm{MHz}\right): \delta 147.6,143.0,139.7,129.2,120.8,118.9,108.2,64.5,49.0,42.3$, 36.0, 31.4, 26.1, 25.4, 23.2, 22.5.

${ }^{19} \mathrm{~F}$ NMR $\left(\mathrm{CDCl}_{3}, 471 \mathrm{MHz}\right): \delta-57.8$.

IR (Diamond-ATR, neat) $\widetilde{v}_{\max }: 2955,2927,2872,1506,1255,1158,1061,986,945,853$.

Specific Rotation $[\alpha]^{23}{ }_{D}:-11.8\left(c=1.0, \mathrm{CHCl}_{3}\right)$.

HRMS (DART) m/z: $[M+H]^{+}$calcd. for $\mathrm{C}_{20} \mathrm{H}_{26} \mathrm{~F}_{3} \mathrm{O}_{3}{ }^{+}: 371.1829$. Found: 371.1829 .

Chiral SFC: Chiralcel OD-H $\left(\mathrm{scCO}_{2} / \mathrm{MeCN}=99.7 / 0.3,1.0 \mathrm{~mL} / \mathrm{min}, 210-400 \mathrm{~nm}, 40{ }^{\circ} \mathrm{C}\right), 24.67 \mathrm{~min}$ (major) and $26.19 \mathrm{~min}$ (minor). 
(1-(4-(1-(10,13-dimethyl-17-(6-methylheptan-2-yl)-2,7,8,9,10,11,12,13,14,15,16,17dodecahydro-1H-cyclopenta[a]phenanthren-3-yl)ethyl)phenyl)-1H-pyrrole (3s)

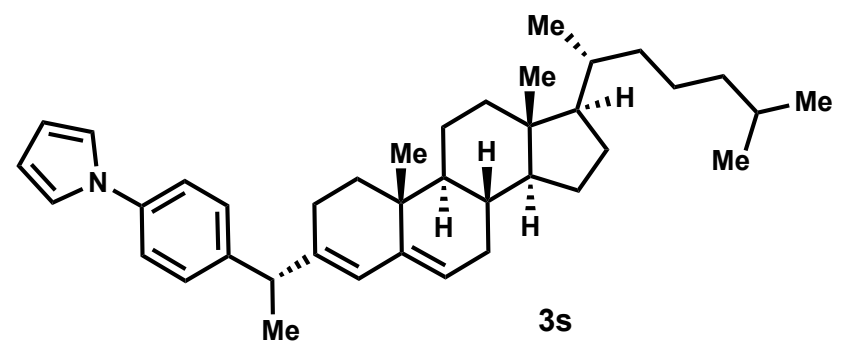

Prepared according to General Procedure C using 1-(4-vinylphenyl)-1H-pyrrole (SI-5I) (84.6 mg, $0.500 \mathrm{mmol}$, 1.0 equiv), and 10,13-dimethyl-17-(6-methylheptan-2-yl)2,7,8,9,10,11,12,13,14,15,16,17-dodecahydro-1H-cyclopenta[a]phenanthren-3-yl trifluoromethanesulfonate (SI-2j) (390 $\mathrm{mg}, 0.75 \mathrm{mmol}, 1.5$ equiv). The residue was purified by automated flash column chromatography on silica gel $\left(50 \mathrm{~g} \mathrm{SiO}_{2}\right.$, gradient elution: hexane to $2.2 \%$ $\mathrm{CH}_{2} \mathrm{Cl}_{2}$ in hexane) to yield $3 \mathrm{~s}$ ( $1^{\text {st }}$ run: $194 \mathrm{mg}, 72 \%,>20: 1 \mathrm{dr} ; 2^{\text {nd }}$ run: $171 \mathrm{mg}, 64 \%,>20: 1 \mathrm{dr}$ ) as a colorless solid.

${ }^{1} \mathrm{H}$ NMR $\left(\mathrm{CDCl}_{3}, 400 \mathrm{MHz}\right): \delta 7.30(\mathrm{~d}, J=8.2 \mathrm{~Hz}, 2 \mathrm{H}), 7.24(\mathrm{~d}, J=8.7 \mathrm{~Hz}, 2 \mathrm{H}), 7.06(\mathrm{dd}, J=2.2$, $2.2 \mathrm{~Hz}, 2 \mathrm{H}), 6.33(\mathrm{dd}, J=2.1,2.1 \mathrm{~Hz}, 2 \mathrm{H}), 5.88(\mathrm{~s}, 1 \mathrm{H}), 5.44-5.38(\mathrm{~m}, 1 \mathrm{H}), 3.43(\mathrm{q}, J=7.1 \mathrm{~Hz}$, $1 \mathrm{H}), 2.19(\mathrm{dt}, J=17.3,4.7 \mathrm{~Hz}, 1 \mathrm{H}), 2.04-1.91(\mathrm{~m}, 3 \mathrm{H}), 1.89-1.81(\mathrm{~m}, 1 \mathrm{H}), 1.79-1.69(\mathrm{~m}, 2 \mathrm{H})$ 1.67-1.58 (m, 2H), 1.54-1.49 (m, 2H), $1.41(\mathrm{~d}, J=7.1 \mathrm{~Hz}, 3 \mathrm{H}), 1.38-1.25(\mathrm{~m}, 5 \mathrm{H}), 1.21-0.95(\mathrm{~m}$, $10 \mathrm{H}), 0.92(\mathrm{~m}, 6 \mathrm{H}), 0.87(\mathrm{dd}, J=6.6,1.8 \mathrm{~Hz}, 6 \mathrm{H}), 0.70(\mathrm{~s}, 3 \mathrm{H})$.

${ }^{13} \mathrm{C}$ NMR $\left(\mathrm{CDCl}_{3}, 101 \mathrm{MHz}\right): \delta 143.3,142.0,139.9,139.0,128.7,124.0,122.7,120.6,119.5,110.2$, 57.2 , 56.3, 48.5, 45.3, 42.6, 40.0, 39.7, 36.3, 35.9, 35.1, 34.4, 32.0, 32.0, 28.4, 28.2, 24.8, 24.3, 24.0, 23.0, 22.7, 21.2, 20.0, 19.1, 18.9, 12.2 .

IR (Diamond-ATR, neat) $\widetilde{v}_{\text {max }}: 2934,2867,1526,1328,1264,1071,922,825,718$.

Specific Rotation $[\alpha]^{23}$ : $-115.5\left(c=1.0, \mathrm{CHCl}_{3}\right)$.

EA calcd. for $\mathrm{C}_{39} \mathrm{H}_{55} \mathrm{~N}$ : C, 87.09; $\mathrm{H}, 10.31$. Found: C, 87.09; $\mathrm{H}, 10.29$.

Melting Point $\left({ }^{\circ} \mathrm{C}\right): 138-140$.

(S)-ethyl 4-(8-(1-(cyclohex-1-en-1-yl)ethyl)-5,6-dihydro-11H-benzo[5,6]cyclohepta[1,2b]pyridin-11-ylidene)piperidine-1-carboxylate (3t)<smiles>CCOC(=O)N1CCC(=C2c3ccc([C@@H](C)C4=CCCCC4)cc3CCc3cccnc32)CC1</smiles>

Prepared according to a modified General Procedure C using ethyl 4-(8-vinyl-5,6-dihydro-11Hbenzo[5,6]cyclohepta[1,2-b]pyridin-11-ylidene)piperidine-1-carboxylate (SI-5f) (187 mg, 0.500 mmol, 1.0 equiv), cyclohex-1-en-1-yl trifluoromethanesulfonate (2a) (170 mg, $0.75 \mathrm{mmol}, 1.5$ equiv), Cul (2.9 mg, $15.0 \mu \mathrm{mol}, 3.0 \mathrm{~mol} \%$ ), (S)-DTBM-SEGPHOS (L1) (20.6 mg, $18.0 \mu \mathrm{mol}, 3.5$ $\mathrm{mol} \%)$, and $\mathrm{Pd}($ cinnamyl)(dppbz) $(\mathrm{Cl})(10.6 \mathrm{mg}, 15.0 \mu \mathrm{mol}, 3.0 \mathrm{~mol} \%)$. The residue was purified by automated flash column chromatography on silica gel $\left(50 \mathrm{~g} \mathrm{SiO}_{2}\right.$, gradient elution: hexane to $5 \%$ 
EtOAc in hexane) to yield $3 \mathrm{t}$ ( $1^{\text {st }}$ run: $153 \mathrm{mg}, 81 \%, 96: 4 \mathrm{er} ; 2^{\text {nd }}$ run: $177 \mathrm{mg}, 78 \%, 96: 4 \mathrm{er}$ ) as a tan solid.

${ }^{1} \mathrm{H}$ NMR $\left(\mathrm{CDCl}_{3}, 400 \mathrm{MHz}\right): \delta 8.37(\mathrm{~d}, J=3.7 \mathrm{~Hz}, 1 \mathrm{H}), 7.41(\mathrm{~d}, J=7.5 \mathrm{~Hz}, 1 \mathrm{H}), 7.09-7.03(\mathrm{~m}, 2 \mathrm{H})$, 6.99-6.94 (m, 2H), $5.55(\mathrm{~s}, 1 \mathrm{H}), 4.12(\mathrm{q}, J=7.1 \mathrm{~Hz}, 2 \mathrm{H}), 3.80(\mathrm{~s}, 2 \mathrm{H}), 3.42-3.30(\mathrm{~m}, 2 \mathrm{H}), 3.22(\mathrm{q}$, $J=7.5 \mathrm{~Hz}, 1 \mathrm{H}), 3.17-3.08(\mathrm{~m}, 2 \mathrm{H}), 2.85-2.76(\mathrm{~m}, 2 \mathrm{H}), 2.50-2.42(\mathrm{~m}, 1 \mathrm{H}), 2.38(\mathrm{t}, J=5.9 \mathrm{~Hz}, 2 \mathrm{H})$, 2.31-2.25 (m, 1H), $2.03(\mathrm{br} \mathrm{s}, 2 \mathrm{H}), 1.80(\mathrm{~d}, J=16.4 \mathrm{~Hz}, 1 \mathrm{H}), 1.71(\mathrm{~d}, J=16.6 \mathrm{~Hz}, 1 \mathrm{H}), 1.55-1.48$ $(\mathrm{m}, 4 \mathrm{H}), 1.29$ (dd, $J=7.1,2.4 \mathrm{~Hz}, 2 \mathrm{H}), 1.25-1.21(\mathrm{~m}, 4 \mathrm{H})$.

${ }^{13} \mathrm{C}$ NMR $\left(\mathrm{CDCl}_{3}, 101 \mathrm{MHz}\right): \delta 158.2,155.6,146.6,145.1,141.2,137.3,136.3,135.5,134.0,129.3$, $128.4,125.2$, 122.1, 120.8, 61.3, 46.3, 46.3, 45.0, 44.9, 32.2, 31.8, 30.8, 30.6, 27.1, 25.4, 23.1, 22.7, 19.8, 19.8, 14.8 .

Complexity due to ring torsion of the central seven-membered ring (see ref. 26)

IR (Diamond-ATR, neat) $\widetilde{v}_{\text {max: }}$ 2969, 2928, 1696, 1436, 1228, 1172, 1113, 997.

Specific Rotation $[\alpha]^{23}$ : $-4.8\left(c=1.0, \mathrm{CHCl}_{3}\right)$.

HRMS (DART) m/z: $[\mathrm{M}+\mathrm{H}]^{+}$calcd. for $\mathrm{C}_{30} \mathrm{H}_{37} \mathrm{~N}_{2} \mathrm{O}_{2}{ }^{+}: 457.2850$. Found: 457.2850 .

Chiral SFC: Chiralcel AD-H $\left(\mathrm{scCO}_{2} / \mathrm{IPA}=95 / 5\right.$ to $60 / 40$ over $8 \mathrm{~min}, 2.5 \mathrm{~mL} / \mathrm{min}, 210-400 \mathrm{~nm}, 45$ $\left.{ }^{\circ} \mathrm{C}\right), 5.71 \mathrm{~min}$ (major) and $5.92 \mathrm{~min}$ (minor).

Melting Point $\left({ }^{\circ} \mathrm{C}\right): 80-82$.

(S)-2-(3-(1-(cyclohept-1-en-1-yl)ethyl)-10H-phenothiazin-10-yl)-N,N-dimethylethan-1-amine (3u)<smiles>C[C@@H](C1=CCCCCC1)c1ccc2c(c1)Sc1ccccc1N2CCN(C)C</smiles>

Prepared according to a modified General Procedure C using N,N-dimethyl-2-(3-vinyl-10Hphenothiazin-10-yl)ethan-1-amine (SI-5g) $(148 \mathrm{mg}, 0.500 \mathrm{mmol}, 1.0$ equiv), cyclohept-1-en-1-yl trifluoromethanesulfonate (SI-2h) $(180 \mathrm{mg}, 0.75 \mathrm{mmol}, 1.5$ equiv), Cul (2.9 mg, $15 \mu \mathrm{mol}, 3.0$ mol\%), (S)-DTBM-SEGPHOS (L1) $(20.6 \mathrm{mg}, 18.0 \mu \mathrm{mol}, 3.5 \mathrm{~mol} \%)$, and Pd(cinnamyl)(dppbz)(Cl) (10.6 $\mathrm{mg}, 15.0 \mu \mathrm{mol}, 3.0 \mathrm{~mol} \%$ ). The residue was purified by automated reversed-phase flash column chromatography according to General Procedure D (40 g C18, gradient elution: $5 \%$ MeCN in water (0.1\% TFA) to $100 \% \mathrm{MeCN})$ to yield $3 \mathrm{u}$ ( $1^{\text {st }}$ run: $131 \mathrm{mg}, 67 \%, 97: 3 \mathrm{er} ; 2^{\text {nd }}$ run: $139 \mathrm{mg}$, $71 \%, 97: 3$ er) as a yellow oil.

${ }^{1} \mathrm{H}$ NMR $\left(\mathrm{CDCl}_{3}, 400 \mathrm{MHz}\right): \delta 7.16-7.10(\mathrm{~m}, 2 \mathrm{H}), 7.03(\mathrm{~d}, \mathrm{~J}=7.8 \mathrm{~Hz}, 1 \mathrm{H}), 6.92-6.86(\mathrm{~m}, 2 \mathrm{H}), 6.78$ (dd, $J=7.8,1.7 \mathrm{~Hz}, 1 \mathrm{H}), 6.72(\mathrm{~s}, 1 \mathrm{H}), 5.74(\mathrm{t}, J=6.4 \mathrm{~Hz}, 1 \mathrm{H}), 3.90(\mathrm{dd}, J=7.1,7.1 \mathrm{~Hz}, 2 \mathrm{H}), 3.31$ (q, $J=7.0 \mathrm{~Hz}, 1 \mathrm{H}), 2.43(\mathrm{t}, J=7.1 \mathrm{~Hz}, 2 \mathrm{H}), 2.22(\mathrm{~s}, 6 \mathrm{H}), 2.18-2.12(\mathrm{~m}, 2 \mathrm{H}), 1.98-1.92(\mathrm{~m}, 2 \mathrm{H})$, $1.68(\mathrm{p}, J=6.0 \mathrm{~Hz}, 2 \mathrm{H}), 1.50-1.43(\mathrm{~m}, 2 \mathrm{H}), 1.34-1.25(\mathrm{~m}, 5 \mathrm{H})$.

${ }^{13} \mathrm{C} \mathrm{NMR}\left(\mathrm{CDCl}_{3}, 101 \mathrm{MHz}\right): \delta 147.9,145.6,145.1,127.5,127.2,127.1,126.0,125.4,122.4,122.2$, $122.0,115.6,115.3,57.4,48.0,45.7,45.6,32.8,32.0,28.5,27.4,27.2,25.3,20.0$.

IR (Diamond-ATR, neat) $\widetilde{\boldsymbol{v}}_{\max }: 2919,2848,2763,1584,1259,1418,1335,1039,812$.

Specific Rotation $[\alpha]^{23}$ : $-4.4\left(\mathrm{c}=1.0, \mathrm{CHCl}_{3}\right)$.

EA calcd. for $\mathrm{C}_{25} \mathrm{H}_{32} \mathrm{~N}_{2} \mathrm{~S}$ : C, 76.48; $\mathrm{H}$, 8.22. Found: $\mathrm{C}, 76.22 ; \mathrm{H}, 8.22$.

Chiral SFC: Chiralcel OJ-H $\left(\mathrm{scCO}_{2} / \mathrm{MeOH} / \mathrm{Et}_{2} \mathrm{NH}=97 / 2.95 / 0.05\right.$ isocratic, $2.5 \mathrm{~mL} / \mathrm{min}, 210-400$ $\left.\mathrm{nm}, 40^{\circ} \mathrm{C}\right), 15.87$ min (minor) and 16.40 min (major). 
Supporting Information

(S)-tert-butyl-4-(1-(4-(quinolin-3-yl)phenyl)ethyl)-3,6-dihydropyridine-1(2H)-carboxylate (3v)<smiles>C[C@H](C1=CCN(C(=O)OC(C)(C)C)CC1)c1ccc(-c2cnc3ccccc3c2)cc1</smiles>

Prepared according to General Procedure C using 3-(4-vinylphenyl)quinoline (SI-5p) (116 mg, $0.500 \mathrm{mmol}, 1.0$ equiv), and tert-butyl 4-((trifluoromethyl)sulfonyl)oxy)-3,6-dihydropyridine-1(2H)carboxylate (SI-2p) (250 mg, $0.75 \mathrm{mmol}, 1.5$ equiv). The residue was purified by automated flash column chromatography on silica gel ( $50 \mathrm{~g} \mathrm{SiO}_{2}$, gradient elution: hexane to $25 \%$ EtOAc in hexane) to yield $3 \mathbf{v}$ ( $1^{\text {st }}$ run: $127 \mathrm{mg}, 61 \%, 97: 3 \mathrm{er} ; 2^{\text {nd }}$ run: $124 \mathrm{mg}, 60 \%, 97: 3 \mathrm{er}$ ) as a colorless solid.

${ }^{1} \mathrm{H}$ NMR $\left(\mathrm{CDCl}_{3}, 400 \mathrm{MHz}\right): \delta 9.20(\mathrm{~s}, 1 \mathrm{H}), 8.38(\mathrm{~s}, 1 \mathrm{H}), 8.24(\mathrm{~s}, 1 \mathrm{H}), 7.92(\mathrm{~d}, J=8.2 \mathrm{~Hz}, 1 \mathrm{H}), 7.77$ $(\mathrm{t}, J=7.7 \mathrm{~Hz}, 1 \mathrm{H}), 7.68-7.59(\mathrm{~m}, 3 \mathrm{H}), 7.36(\mathrm{~d}, J=8.1 \mathrm{~Hz}, 2 \mathrm{H}), 5.59(\mathrm{~s}, 1 \mathrm{H}), 3.96(\mathrm{~s}, 2 \mathrm{H}), 3.51-$ $3.38(\mathrm{~m}, 3 \mathrm{H}), 2.02-1.91(\mathrm{~m}, 2 \mathrm{H}), 1.46(\mathrm{~s}, 9 \mathrm{H}), 1.43(\mathrm{~d}, J=7.1 \mathrm{~Hz}, 3 \mathrm{H})$.

${ }^{13} \mathrm{C}$ NMR $\left(\mathrm{CDCl}_{3}, 101 \mathrm{MHz}\right): \delta 155.0,145.1,140.0,135.8,133.3,130.0,129.5,129.2,128.5,128.1$, 128.0, 127.5, 127.2, 120.7, 118.3, 79.6, 45.7, 43.8, 41.3, 39.9, 28.6, 27.4, 19.6.

IR (Diamond-ATR, neat) $\widetilde{v}_{\text {max: }}$ 2973, 2930, 1736, 1689, 1419, 1364, 1238, 1045, 953, 837, 736.

Specific Rotation $[\alpha]^{23}{ }_{\mathrm{D}}:-10.9\left(c=1.0, \mathrm{CHCl}_{3}\right)$.

HRMS (DART) m/z: $[\mathrm{M}+\mathrm{H}]^{+}$calcd. $\mathrm{C}_{27} \mathrm{H}_{31} \mathrm{~N}_{2} \mathrm{O}_{2}{ }^{+}: 415.2380$. Found: 415.2387.

Chiral SFC: Chiralcel AS-H $\left(\mathrm{scCO}_{2} / \mathrm{IPA}=95 / 5\right.$ to $60 / 40$ over $8 \mathrm{~min}, 2.5 \mathrm{~mL} / \mathrm{min}, 210-400 \mathrm{~nm}, 45$

$\left.{ }^{\circ} \mathrm{C}\right), 4.86 \mathrm{~min}$ (major), $5.02 \mathrm{~min}$ (minor).

Melting Point $\left({ }^{\circ} \mathrm{C}\right): 58-62$.

(S)-N,N-dibenzyl-3-(cyclohex-1-en-1-yl)-3-phenylpropan-1-amine (3w)

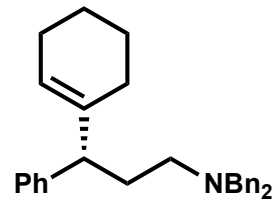

$3 w$

Prepared according to a modified General Procedure C using (E)-N,N-dibenzyl-3-phenylprop-2en-1-amine (SI-5h) (157 mg, 0.500 mmol, 1.0 equiv), cyclohex-1-en-1-yl trifluoromethanesulfonate (2a) (170 mg, $0.75 \mathrm{mmol}, 1.5$ equiv), and $\mathrm{Pd}($ cinnamyl)(dppbz)(Cl) $(7.1 \mathrm{mg}, 10 \mu \mathrm{mol}, 2.0 \mathrm{~mol} \%)$. The residue was purified by automated reversed-phase flash column chromatography according to General Procedure D (40 g C18, gradient elution: $5 \% \mathrm{MeCN}$ in water (0.1\% TFA) to $20 \% \mathrm{MeCN}$ in water $(0.1 \%$ TFA $)$ to yield $3 \mathbf{w}\left(1^{\text {st }}\right.$ run: $117 \mathrm{mg}, 59 \%, 99: 1 \mathrm{er} ; 2^{\text {nd }}$ run: $\left.126 \mathrm{mg}, 64 \%, 99: 1 \mathrm{er}\right)$ as a yellow oil.

${ }^{1} \mathrm{H}$ NMR $\left(\mathrm{CDCl}_{3}, 400 \mathrm{MHz}\right): \delta$ 7.38-7.27 (m, 8H), 7.25-7.19 (m, 4H), 7.18-7.08 (m, 3H), 5.52-5.47 $(\mathrm{m}, 1 \mathrm{H}), 3.56(\mathrm{q}, J=13.6 \mathrm{~Hz}, 4 \mathrm{H}), 3.13(\mathrm{t}, J=7.6 \mathrm{~Hz}, 1 \mathrm{H}), 2.49-2.40(\mathrm{~m}, 1 \mathrm{H}), 2.39-2.31(\mathrm{~m}, 1 \mathrm{H})$, $2.07-1.86(\mathrm{~m}, 4 \mathrm{H}), 1.75-1.60(\mathrm{~m}, 2 \mathrm{H}), 1.51-1.38(\mathrm{~m}, 4 \mathrm{H})$.

${ }^{13} \mathrm{C}$ NMR $\left(\mathrm{CDCl}_{3}, 101 \mathrm{MHz}\right): \delta 144.7,140.0,139.7,129.0,128.2,128.2,127.9,126.8,125.9,121.6$, $58.5,51.8,50.5,30.0,26.6,25.4,23.1,22.6$.

IR (Diamond-ATR, neat) $\widetilde{v}_{\text {max }}: 3056,3019,2933,2833,2780,1601,1491,1455,1123,1031,915$, 693.

Specific Rotation $[\alpha]^{23}{ }_{\mathrm{D}}:-17.0\left(c=1.0, \mathrm{CHCl}_{3}\right)$.

HRMS (DART) m/z: $[\mathrm{M}+\mathrm{H}]^{+}$calcd. for $\mathrm{C}_{29} \mathrm{H}_{34} \mathrm{~N}^{+}: 396.2686$. Found: 396.2696. 
Chiral SFC: Chiralcel OD-H ( $\mathrm{scCO}_{2} / \mathrm{IPA}=95 / 5$ to $60 / 40$ over $8 \mathrm{~min}, 2.5 \mathrm{~mL} / \mathrm{min}, 210-400 \mathrm{~nm}, 45$ $\left.{ }^{\circ} \mathrm{C}\right), 4.87 \mathrm{~min}$ (minor) and $5.16 \mathrm{~min}$ (major).

\section{(S)-3-(cyclohex-1-en-1-yl)-N,N-dimethyl-3-phenylpropan-1-amine (3x)}<smiles>CNCCC(C1=CCCCC1)c1ccccc1</smiles>

Prepared according to a modified General Procedure C using (E)-N,N-dimethyl-3-phenylprop-2en-1-amine (SI-5i) (81 mg, $0.50 \mathrm{mmol}, 1.0$ equiv), cyclohex-1-en-1-yl trifluoromethanesulfonate (2a) $(170 \mathrm{mg}, 0.75 \mathrm{mmol}, 1.5$ equiv), and $\mathrm{Pd}($ cinnamyl)(dppbz)(Cl) $(7.1 \mathrm{mg}, 10 \mu \mathrm{mol}, 2.0 \mathrm{~mol} \%)$. The residue was purified by automated reversed-phase flash column chromatography according to General Procedure D ( $40 \mathrm{~g} \mathrm{C18}$, gradient elution: $5 \% \mathrm{MeCN}$ in water $(0.1 \% \mathrm{TFA})$ to $100 \%$ $\mathrm{MeCN})$ to yield $3 \times\left(1^{\text {st }}\right.$ run: $82 \mathrm{mg}, 67 \%, 81: 19 \mathrm{er} ; 2^{\text {nd }}$ run: $\left.90 \mathrm{mg}, 74 \%, 81: 19 \mathrm{er}\right)$ as an orange oil.

${ }^{1} \mathrm{H}$ NMR yield was determined using a modified General Procedure $\mathbf{C}$ using $(E)-N, N$-dimethyl-3phenylprop-2-en-1-amine (SI-5i) (81 mg, 0.50 mmol, 1.0 equiv), cyclohex-1-en-1-yl (4methylbenzenesulfonate) (2a) $(170 \mathrm{mg}, 0.75 \mathrm{mmol}, 1.5$ equiv), $\mathrm{Pd}($ cinnamyl)(dppbz)(Cl) $(7.1 \mathrm{mg}$, $10 \mu \mathrm{mol}, 2.0 \mathrm{~mol} \%$ ). 1,1,2,2-tetrachloroethane was utilized as internal standard: $77 \%$ yield, 92:8 er.

${ }^{1} \mathrm{H}$ NMR $\left(\mathrm{CDCl}_{3}, 400 \mathrm{MHz}\right): \delta 7.31-7.25(\mathrm{~m}, 2 \mathrm{H}), 7.23-7.16(\mathrm{~m}, 3 \mathrm{H}), 5.67-5.61(\mathrm{~m}, 1 \mathrm{H}), 3.16(\mathrm{t}, \mathrm{J}$ $=7.6 \mathrm{~Hz}, 1 \mathrm{H}), 2.27-2.19(\mathrm{~m}, 7 \mathrm{H}), 2.13(\mathrm{ddd}, J=11.9,9.7,5.1 \mathrm{~Hz}, 1 \mathrm{H}), 2.08-1.95(\mathrm{~m}, 3 \mathrm{H}), 1.92-$ $1.68(\mathrm{~m}, 3 \mathrm{H}), 1.57-1.48(\mathrm{~m}, 4 \mathrm{H})$.

${ }^{13} \mathrm{C}$ NMR $\left(\mathrm{CDCl}_{3}, 101 \mathrm{MHz}\right): \delta 144.1,139.9,128.3,127.9,126.2,121.7,58.3,50.9,45.4,30.3$, 26.7, 25.5, 23.1, 22.7.

IR (Diamond-ATR, neat) $\widetilde{v}_{\text {max: }}$ 3026, 2926, 2856, 2835, 1674, 1493, 1452, 1411, 1275, 1199 , 1173, 1031, 968, 829, 798.

Specific Rotation $[\alpha]^{23}{ }_{\mathrm{D}}:-9.3\left(c=1.0, \mathrm{CHCl}_{3}\right)$.

HRMS (DART) m/z: $[\mathrm{M}+\mathrm{H}]^{+}$calcd. for $\mathrm{C}_{17} \mathrm{H}_{26} \mathrm{~N}^{+}:$244.2060. Found: 244.2066.

Chiral HPLC: Supelco CLSIC-128 (hexane/MeOH $(0.1 \%$ TFA) = 96/4 $1 \mathrm{~mL} / \mathrm{min}, 210 \mathrm{~nm}), 24.61$ min (major) and 31.05 min (minor). 
Supporting Information

4.4. Reduction of $3 x$ to (S)-Gamfexine (4)<smiles>CN(C)CC[C@H](C1=CCCCC1)c1ccccc1</smiles>
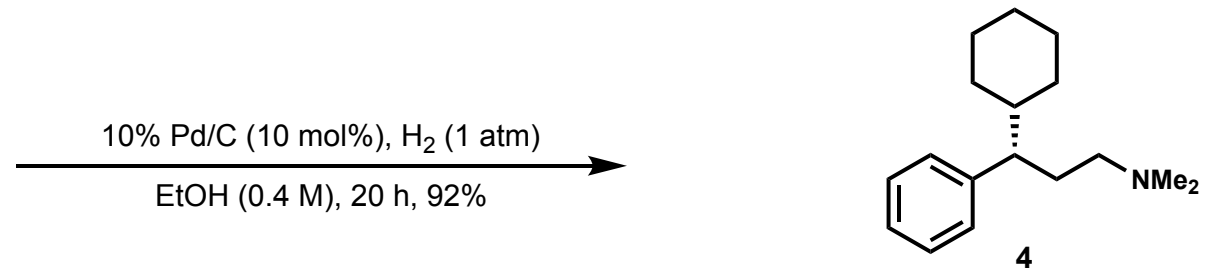

To an oven-dried reaction tube (Fisherbrand, $13 \times 100 \mathrm{~mm}, 1495935 \mathrm{C}$ ) equipped with a magnetic stir bar was charged $10 \% \mathrm{Pd} / \mathrm{C}(3.0 \mathrm{mg}, 2.2 \mu \mathrm{mol}, 15 \mathrm{~mol} \%)$, the tube was sealed with a screw cap containing a PTFE septum (cap: Kimble Chase Open Top S/T Closure catalog no. 73804-15425; Septum: Thermo Scientific $1.3 \mathrm{~mm}$ silicone/PTFE catalog no. B7995-18) [Caution: dry $\mathrm{Pd} / \mathrm{C}$ can cause fires in a laboratory environment]. ${ }^{27}$ The reaction vessel was then evacuated and backfilled with nitrogen (this process was repeated a total of three times) connected via a needle and hose to a dual manifold Schlenk line. Next, a solution of $3 \mathbf{x}(35 \mathrm{mg}, 0.14 \mathrm{mmol}, 1.0$ equiv) in ethanol ( $500 \mu \mathrm{L}, 0.3 \mathrm{M})$ was added carefully down the side of the flask wall using a plastic syringe by puncturing the septum. While the reaction mixture was stirring, the reaction mixture was sparged with $\mathrm{N}_{2}$ by puncturing the septum with an exit needle and carefully submerging the needle connected to the dual manifold Schlenk line into the reaction mixture (ca. $2 \mathrm{~min}$ ). The submerged needle was removed from the reaction solvent and placed in the headspace of the reaction vessel. Following this, the exit needle was removed from the septum. The Schlenk line was closed to nitrogen, and the flask was then carefully backfilled with hydrogen using a needle connected to a hydrogen-filled balloon.

The reaction mixture was then sparged with hydrogen by puncturing the septum with an exit needle and carefully submerging the needle connected to the hydrogen-filled balloon in the solvent of the reaction mixture until bubbles were observed. After 1 min of bubbling hydrogen through the reaction mixture, the needle attached to the hydrogen-filled balloon was removed from the reaction solvent and placed in the headspace of the reaction vessel. Following this, the exit needle was removed from the septum. The reaction mixture was allowed to stir at room temperature for $20 \mathrm{~h}$.

After $20 \mathrm{~h}$, the hydrogen balloon was removed from the reaction vessel. Using a needle connected to a dual manifold Schlenk line, a gentle stream of nitrogen was directed into the flask, and the hydrogen in the headspace was displaced with an exit needle. (Caution: as detailed in ref. 27 , ensure that hydrogen is fully removed by carefully bubbling nitrogen through the solution. This will reduce the risk of fire during the subsequent filtration). After $5 \mathrm{~min}$, the mixture was filtered through a $1.5 \mathrm{~cm}$ plug of packed Celite to remove $\mathrm{Pd} / \mathrm{C}$, the Celite pad was never allowed to go dry. The Celite pad was washed with additional EtOAc (ca. $5 \mathrm{~mL} \times 2)$. (Caution: during the filtration, solvent should be continuously added so that the Celite and other solids do not fully dry. The Pd/C at the top of the filter cake may ignite if not continuously covered with solvent. After the filtration is complete, the wet filter cake was filled with dry sand and carefully transferred to a labelled waste bottle containing water) ${ }^{27}$

The filtrate was then concentrated in vacuo with the aid of a rotary evaporator. The resulting residue was $>95 \%$ pure, as observed by ${ }^{1} \mathrm{H}$ NMR. The crude oil could be further purified, if necessary, by adding cold pentane $(2.5 \mathrm{~mL})$ to a $20 \mathrm{~mL}$ scintillation vial containing the product. The vial was capped and placed in a freezer at $-20^{\circ} \mathrm{C}$ for $2 \mathrm{~h}$, at which point a thick colorless oil was observed. The pentane layer was carefully pipetted away from the resulting oil layer. The resulting residue was concentrated in vacuo with the aid of a rotary evaporator to yield $(S)$ gamfexine (4) (33 mg, 92\%, 79:21 er) as a colorless oil.

${ }^{1} \mathrm{H}$ NMR $\left(\mathrm{CDCl}_{3}, 400 \mathrm{MHz}\right): \delta 7.31-7.25(\mathrm{~m}, 2 \mathrm{H}), 7.19$ (dddd, $\left.J=7.3,7.3,2.1,1.3 \mathrm{~Hz}, 1 \mathrm{H}\right), 7.12-$ $7.07(\mathrm{~m}, 2 \mathrm{H}), 2.46-2.37(\mathrm{~m}, 1 \mathrm{H}), 2.39(\mathrm{~s}, 6 \mathrm{H}), 2.32$ (ddd, $J=11.1,7.7,3.5 \mathrm{~Hz}, 1 \mathrm{H}), 2.22-2.06(\mathrm{~m}$, 
$2 \mathrm{H}), 1.94-1.78(\mathrm{~m}, 2 \mathrm{H}), 1.77-1.69(\mathrm{~m}, 1 \mathrm{H}), 1.65-1.55(\mathrm{~m}, 2 \mathrm{H}), 1.50-1.35(\mathrm{~m}, 2 \mathrm{H}), 1.28-1.15(\mathrm{~m}$, $1 \mathrm{H}), 1.13-1.02(\mathrm{~m}, 2 \mathrm{H}), 0.93(\mathrm{qd}, J=12.5,3.5 \mathrm{~Hz}, 1 \mathrm{H}), 0.77(\mathrm{qd}, J=12.2,3.3 \mathrm{~Hz}, 1 \mathrm{H})$.

${ }^{13} \mathrm{C}$ NMR $\left(\mathrm{CDCl}_{3}, 101 \mathrm{MHz}\right): \delta 144.1,128.5,128.2,126.1,58.4,50.4,45.3,43.5,31.4,31.1,30.3$, 26.7, 26.7, 26.6.

IR (Diamond-ATR, neat) $\widetilde{\boldsymbol{v}}_{\text {max }}: 2921,2851,1677,1450,1199,1130,829,700$.

Specific Rotation $[\alpha]^{23}{ }_{\mathrm{D}}:-10.4\left(c=1.0, \mathrm{CHCl}_{3}\right)$.

HRMS (DART) m/z: [M+H] ${ }^{+}$calcd. for $\mathrm{C}_{17} \mathrm{H}_{28} \mathrm{~N}^{+}:$246.2216. Found: 246.2225 .

Chiral HPLC: Supelco CLSIC-128 (hexane/MeOH $(0.1 \%$ TFA) $=99.1 / 0.91 .75 \mathrm{~mL} / \mathrm{min}, 210 \mathrm{~nm}$, $\left.60^{\circ} \mathrm{C}\right), 29.92 \mathrm{~min}$ (major) and $31.71 \mathrm{~min}$ (minor).

Note: The column should be heated and equilibrated for $>2 \mathrm{hrs}$ prior to injection to maintain reproducible retention times. The column was covered with foil to maintain uniform temperature throughout. 


\subsection{Large Scale Bench Top Setup}<smiles>C[C@H](C1=CCCCC1)c1ccc(-c2ccccc2)cc1</smiles>

To a flame-dried $35 \mathrm{~mL}$ threaded high-pressure reaction tube (Ace Glass 8648-07) equipped with magnetic stir bar, labeled as "A", was added NaOTMS (1.12 g, $10.0 \mathrm{mmol}, 2.0$ equiv), (S)-DTBM-SEGPHOS (L1) $(118 \mathrm{mg}, 100 . \mu \mathrm{mol}, 2.0 \mathrm{~mol} \%)$ and Cul (14.3 mg, $75.0 \mu \mathrm{mol}$, $1.5 \mathrm{~mol} \%$ ). The reaction tube was fitted with a rubber septum, attached by rubber hose via a needle to a dual manifold Schlenk line. The reaction tube was then evacuated and refilled with $\mathrm{N}_{2}$ (this process was repeated a total of three times). To the reaction vessel was added THF (4.75 mL, $1.05 \mathrm{M}$ ) via syringe by puncturing the rubber septum and the reaction mixture was allowed to stir at room temperature for $10 \mathrm{~min}$.

To an oven-dried reaction tube (Fisherbrand, $13 \times 100 \mathrm{~mm}, 1495935 \mathrm{C}$ ), labeled as "B", was added cyclohex-1-en-1-yl trifluoromethanesulfonate (2a) $(1.73 \mathrm{~g}, 7.50 \mathrm{mmol}, 1.5$ equiv) and THF $(4.0 \mathrm{~mL}, 1.9 \mathrm{M})$. The reaction vial was capped with a screw cap containing a PTFE septum (cap: Fisher Scientific, Closure OT S/T 18-400, Cat. No. 033407G; Septum: Thermo Scientific, Septa T/S for 18-400Cap, Cat. No. B7995-18) and allowed to stand at room temperature.

After the reaction mixture had stirred for $10 \mathrm{~min}$ at room temperature, $\mathrm{Me}_{2} \mathrm{PhSiH}(1.53 \mathrm{~mL}$, $10.0 \mathrm{mmol}, 2.0$ equiv) was added dropwise to reaction tube $\mathbf{A}$ using a $2 \mathrm{~mL}$ plastic syringe by puncturing the rubber septum. Once the reaction mixture had stirred for an additional $10 \mathrm{~min}$, the rubber septum was removed and 4-vinyl-1,1'-biphenyl (1b) (901 mg, $5.00 \mathrm{mmol}, 1.0$ equiv) was added to the reaction mixture followed by $\mathrm{Pd}($ cinnamyl)(dppbz)(Cl) $(52.9 \mathrm{mg}, 75.0 \mu \mathrm{mol}, 1.5$ $\mathrm{mol} \%$ ), resulting in a red-orange-colored reaction mixture. The reaction tube was resealed with the rubber septum. The entirety of reaction tube $\mathbf{B}$, containing the alkenyl coupling partner solution, was added to the reaction mixture using a $2 \mathrm{~mL}$ plastic syringe by puncturing the rubber septum. The rubber septum was replaced with a threaded PTFE stopper with a rubber O-ring (Ace Glass \#15 Plug, 5846-48). Reaction tube A was then placed in an oil bath preheated to $60^{\circ} \mathrm{C}$.

After the reaction mixture had stirred for $16 \mathrm{~h}$ at $60^{\circ} \mathrm{C}$, the reaction vessel was removed from the oil bath and the reaction mixture was allowed cool to room temperature. Once the reaction mixture had cooled to room temperature, the reaction mixture was diluted with EtOAc $(15 \mathrm{~mL})$ and filtered through a $3 \mathrm{~cm}$ pad of packed Celite using a fritted funnel, which was subsequently washed with additional EtOAc $(2 \times 15 \mathrm{~mL})$. The filtrate was concentrated in vacuo with the aid of a rotary evaporator. The resulting crude residue was purified by automated silica flash column chromatography (200 $\mathrm{g} \mathrm{SiO}_{2}$, hexane). Residual silane byproducts could be removed in vacuo (ca. 500 mtorr) by heating to $60^{\circ} \mathrm{C}$ for $5 \mathrm{~h}$ to yield $3 y$ (969 mg, 74\%, 93:7 er) as a colorless solid.

Note: All chemicals, with the exception of $\mathrm{Me}_{2} \mathrm{PhSiH}$, were removed from a nitrogen-filled glovebox in individual $20 \mathrm{~mL}$ scintillation vials and stored in a desiccator prior to use. $\mathrm{Me}_{2} \mathrm{PhSiH}$ was used directly as received.

${ }^{1} \mathrm{H}$ NMR $\left(\mathrm{CDCl}_{3}, 400 \mathrm{MHz}\right)$ : $\delta 7.63-7.59(\mathrm{~m}, 2 \mathrm{H}), 7.54(\mathrm{dt}, J=8.3,1.8 \mathrm{~Hz}, 2 \mathrm{H}), 7.47-7.41(\mathrm{~m}, 2 \mathrm{H})$, 7.34 (dddd, $J=7.3,7.3,1.7,1.1 \mathrm{~Hz}, 1 \mathrm{H}), 7.29(\mathrm{~d}, J=8.2 \mathrm{~Hz}, 2 \mathrm{H}), 5.67-5.63(\mathrm{~m}, 1 \mathrm{H}), 3.36(\mathrm{q}, J$ $=7.2 \mathrm{~Hz}, 1 \mathrm{H}), 2.16-2.05(\mathrm{~m}, 2 \mathrm{H}), 1.93-1.75(\mathrm{~m}, 2 \mathrm{H}), 1.63-1.55(\mathrm{~m}, 4 \mathrm{H}), 1.40(\mathrm{~d}, J=7.1 \mathrm{~Hz}, 3 \mathrm{H})$. 
${ }^{13} \mathrm{C}$ NMR $\left(\mathrm{CDCl}_{3}, 101 \mathrm{MHz}\right): \delta 145.3,141.3,141.3,138.9,128.8,128.0,127.1,127.1,127.0,121.0$, 46.3, 27.3, 25.5, 23.2, 22.8, 19.9 .

IR (Diamond-ATR, neat) $\widetilde{\boldsymbol{v}}_{\text {max: }}$ 3026, 2957, 2927, 2835, 1485, 1449, 1428, 1252, 1118, 1048 , 835, 803, 696.

Specific Rotation $[\alpha]^{23}$ : $-7.7\left(c=1.0, \mathrm{CHCl}_{3}\right)$.

HRMS (DART) m/z: [M+H] $]^{+}$calcd. for $\mathrm{C}_{20} \mathrm{H}_{23}{ }^{+}: 263.1794$. Found: 263.1799 .

Chiral SFC: Chiralcel OD-H ( $\mathrm{scCO}_{2} / \mathrm{IPA}=95 / 5$ to $80 / 20$ over $20 \mathrm{~min}, 2.5 \mathrm{~mL} / \mathrm{min}, 210-400 \mathrm{~nm}$, $\left.45^{\circ} \mathrm{C}\right), 6.48 \mathrm{~min}$ (major) and 6.89 min (minor).

Melting Point $\left({ }^{\circ} \mathrm{C}\right): 58-62$. 


\subsection{Characterization of Hydroalkenylation of Unactivated Olefin Products}

$(1 S, 2 S, 4 S, 5 R)-2-((R)-((t e r t-b u t y l d i m e t h y l s i l y l) o x y)(6-m e t h o x y q u i n o l i n-3-y l) m e t h y l)-5-(2-(6,7-$ dimethoxy-3,4-dihydronaphthalen-1-yl)ethyl)quinuclidine (6a)<smiles></smiles>

Prepared according to a modified General Procedure C using $(2 S, 5 S)-2-((R)-(($ tertbutyldimethylsilyl)oxy)(6-methoxyquinolin-4-yl)methyl)-5-vinylquinuclidine SI-11a (291 mg, 0.500 mmol, 1.0 equiv), 6,7-dimethoxy-3,4-dihydronaphthalen-1-yl trifluoromethanesulfonate (SI-2w) (254 mg, 0.750 mmol, 1.5 equiv) ), Cul (2.9 mg, 15 mmol, $3.0 \mathrm{~mol} \%)$, ( \pm )-DTBM-SEGPHOS (L1) (20.6 mg, $18.0 \mu \mathrm{mol}, 3.5 \mathrm{~mol} \%$ ), and $\mathrm{Pd}($ cinnamyl)(dppbz)(Cl) (10.6 mg, $15.0 \mu \mathrm{mol}, 3.0 \mathrm{~mol} \%)$. The residue was purified by automated reversed-phase flash column chromatography according to General Procedure D, $(50 \mathrm{~g} \mathrm{C18}$, gradient elution: $5 \% \mathrm{MeCN}$ in water $(0.1 \% \mathrm{TFA})$ to $50 \%$ MeCN in water ( $0.1 \%$ TFA $)$ ) to yield $6 a\left(1^{\text {st }}\right.$ run: $165 \mathrm{mg}, 52 \% ; 2^{\text {nd }}$ run: $\left.170 \mathrm{mg}, 54 \%\right)$ as a tan solid.

${ }^{1} \mathrm{H}$ NMR $\left(\mathrm{CDCl}_{3}, 500 \mathrm{MHz}\right.$ ) (Major Rotamer): $\delta 8.74(\mathrm{~d}, J=4.5 \mathrm{~Hz}, 1 \mathrm{H}), 8.03(\mathrm{~d}, J=9.2 \mathrm{~Hz}, 1 \mathrm{H})$, $7.54(\mathrm{~d}, J=4.5 \mathrm{~Hz}, 1 \mathrm{H}), 7.39-7.35(\mathrm{~m}, 1 \mathrm{H}), 7.17(\mathrm{~s}, 1 \mathrm{H}), 6.82(\mathrm{~s}, 1 \mathrm{H}), 6.73(\mathrm{~s}, 1 \mathrm{H}), 5.77(\mathrm{t}, J=4.7$ $\mathrm{Hz}, 1 \mathrm{H}), 5.62(\mathrm{~s}, 1 \mathrm{H}), 3.93(\mathrm{~s}, 3 \mathrm{H}), 3.90(\mathrm{~s}, 3 \mathrm{H}), 3.89(\mathrm{~s}, 3 \mathrm{H}), 3.08(\mathrm{dd}, \mathrm{J}=13.4,8.4 \mathrm{~Hz}, 1 \mathrm{H}), 2.94$ (dd, $J=13.2,9.2 \mathrm{~Hz}, 1 \mathrm{H}), 2.90-2.80(\mathrm{~m}, 2 \mathrm{H}), 2.79-2.71(\mathrm{~m}, 1 \mathrm{H}), 2.68(\mathrm{t}, J=7.5 \mathrm{~Hz}, 2 \mathrm{H}), 2.54-$ $2.30(\mathrm{~m}, 2 \mathrm{H}), 2.27-2.21(\mathrm{~m}, 2 \mathrm{H}), 2.05(\mathrm{dd}, J=12.9,9.2 \mathrm{~Hz}, 1 \mathrm{H}), 1.86-1.52(\mathrm{~m}, 4 \mathrm{H}), 1.48-1.39(\mathrm{~m}$, $2 \mathrm{H}), 1.05-1.00(\mathrm{~m}, 1 \mathrm{H}), 0.92(\mathrm{~s}, 9 \mathrm{H}), 0.12(\mathrm{~s}, 3 \mathrm{H}),-0.32(\mathrm{~s}, 3 \mathrm{H})$.

Complexity due to hindered rotation (see ref. 23)

${ }^{13} \mathrm{C}$ NMR $\left(\mathrm{CDCl}_{3}, 126 \mathrm{MHz}\right)$ (mixture of rotamers): $\delta$ 158.0, 156.7, 148.3, 147.7, 147.6, 147.4, 147.3, 145.6, 144.5, 136.2, 136.0, 133.2, 132.1, 131.6, 129.8, 129.7, 128.0, 127.8, 127.2, 126.4, 123.0, 122.7, 121.7, 121.4, 119.0, 111.7, 111.7, 107.6, 107.5, 105.0, 100.7, 79.9, 73.5, 61.1, 56.5, $56.1,55.9,55.5,51.7,50.7,50.1,49.7,35.8,35.4,32.1,31.2,31.1,30.6,29.4,28.3,28.3,27.6$, 27.3, 27.0, 26.7, 26.5, 26.2, 25.9, 23.4, 20.4, 18.2, 18.2, $-4.5,-4.5,-4.6,-5.1$.

Complexity due to hindered rotation (see ref. 23 )

IR (Diamond-ATR, neat) $\widetilde{v}_{\text {max }}$ 3027, 2958, 2930, 2835, 1485, 1449, 1252, 1118, $1050,835$.

Specific Rotation $[\alpha]^{23}$ : $+87.0\left(c=1.0, \mathrm{CHCl}_{3}\right)$.

HRMS (DART) m/z: [M+H] ${ }^{+}$calcd. for $\mathrm{C}_{38} \mathrm{H}_{53} \mathrm{~N}_{2} \mathrm{O}_{4} \mathrm{Si}^{+}:$629.3769. Found: 629.3762.

Melting Point $\left({ }^{\circ} \mathrm{C}\right): 50-52$. 
Supporting Information

(士)-5-(9-(2-(cyclohex-3-en-1-yl)ethyl)-6,7-dihydro-5H-benzo[7]annulen-8-yl)-2methoxypyridine (6b)<smiles>COc1ccc(C2=C(CCC3CC=CCC3)c3ccccc3CCC2)cn1</smiles>

6b

Prepared according to General Procedure $\mathbf{C}$ using 4-vinylcyclohex-1-ene (54 mg, $0.50 \mathrm{mmol}, 1.0$ equiv) and 8-(6-methoxypyridin-3-yl)-6,7-dihydro-5H-benzo[7]annulen-9-yl trifluoromethanesulfonate (SI-2k) $\left(0.30 \mathrm{~g}, 0.75 \mathrm{mmol}, 1.5\right.$ equiv) at $45^{\circ} \mathrm{C}$. The residue was purified by automated flash column chromatography on silica gel $\left(50 \mathrm{~g} \mathrm{SiO}_{2}\right.$, gradient elution: hexane to $30 \% \mathrm{CH}_{2} \mathrm{Cl}_{2}$ in hexane) to yield $6 \mathrm{~b}$ ( $1^{\text {st }}$ run: $103 \mathrm{mg}, 57 \% ; 2^{\text {nd }}$ run: $\left.96 \mathrm{mg}, 53 \%\right)$ as a colorless oil.

${ }^{1} \mathrm{H}$ NMR $\left(\mathrm{CDCl}_{3}, 400 \mathrm{MHz}\right): \delta 8.11(\mathrm{~d}, J=2.1 \mathrm{~Hz}, 1 \mathrm{H}), 7.49(\mathrm{dd}, J=8.5,2.4 \mathrm{~Hz}, 1 \mathrm{H}), 7.35-7.31$ $(\mathrm{m}, 1 \mathrm{H}), 7.28(\mathrm{dd}, J=6.2,2.3 \mathrm{~Hz}, 1 \mathrm{H}), 7.24-7.17(\mathrm{~m}, 2 \mathrm{H}), 6.77(\mathrm{~d}, J=8.5 \mathrm{~Hz}, 1 \mathrm{H}), 5.63-5.52(\mathrm{~m}$, $2 \mathrm{H}), 3.98(\mathrm{~s}, 3 \mathrm{H}), 2.67(\mathrm{t}, J=6.7 \mathrm{~Hz}, 2 \mathrm{H}), 2.48(\mathrm{dd}, J=8.1,8.1 \mathrm{~Hz}, 2 \mathrm{H}), 2.17-2.03(\mathrm{~m}, 4 \mathrm{H}), 1.97-$ $1.88(\mathrm{~m}, 3 \mathrm{H}), 1.58-1.32(\mathrm{~m}, 3 \mathrm{H}), 1.23-1.16(\mathrm{~m}, 2 \mathrm{H}), 1.10-0.99(\mathrm{~m}, 1 \mathrm{H})$.

${ }^{13} \mathrm{C}$ NMR $\left(\mathrm{CDCl}_{3}, 101 \mathrm{MHz}\right): \delta$ 162.8, 145.9, 141.4, 141.1, 139.0, 138.6, 133.8, 132.8, 128.7, 127.1, 126.8, 126.6, 126.3, 126.1, 110.4, 53.5, 36.5, 34.1, 33.8, 32.9, 32.0, 31.8, 30.7, 28.7, 25.3.

IR (Diamond-ATR, neat) $\widetilde{\boldsymbol{v}}_{\max }: 3016,2915,2853,1597,1489,1280,1025,831$.

HRMS (DART) m/z: [M+H] $]^{+}$calcd. for $\mathrm{C}_{25} \mathrm{H}_{30} \mathrm{NO}^{+}: 360.2322$. Found: 360.2333.

(士)-3-(3-(3-(2-fluoro-4-methoxyphenyl)propyl)cyclohex-2-en-1-yl)-1-methyl-1H-indole (6c)<smiles>COc1ccc(CCCC2=CC(c3cn(C)c4ccccc34)CCC2)c(F)c1</smiles>

6c

Prepared according to a modified General Procedure $\mathbf{C}$ using 1-allyl-2-fluoro-4-methoxybenzene (SI-11b) $\quad(83 \mathrm{mg}, \quad 0.50 \mathrm{mmol}, 1.0$ equiv), 3-(1-methyl-1H-indol-3-yl)cyclohex-1-en-1-yl trifluoromethanesulfonate SI-2I (270 mg, $0.75 \mathrm{mmol}, 1.5$ equiv) ), Cul (2.9 mg, $15 \mu \mathrm{mol}, 3.0 \mathrm{~mol} \%)$, ( \pm )-DTBM-SEGPHOS (L1) $(20.6 \mathrm{mg}, 18.0 \mu \mathrm{mol}, 3.5 \mathrm{~mol} \%)$, and Pd(cinnamyl)(dppbz)(Cl) (10.6 $\mathrm{mg}, 15.0 \mu \mathrm{mol}, 3.0 \mathrm{~mol} \%$ ) at $45^{\circ} \mathrm{C}$. The residue was purified by automated flash column chromatography on silica gel (50 g SiO 2 , gradient elution: hexane to $20 \% \mathrm{CH}_{2} \mathrm{Cl}_{2}$ in hexane) to yield $6 \mathrm{c}\left(1^{\text {st }}\right.$ run: $134 \mathrm{mg}, 71 \% ; 2^{\text {nd }}$ run: $\left.146 \mathrm{mg}, 77 \%\right)$ as a yellow oil.

${ }^{1} \mathrm{H}$ NMR $\left(\mathrm{CDCl}_{3}, 400 \mathrm{MHz}\right): \delta 7.68(\mathrm{~d}, J=7.9 \mathrm{~Hz}, 1 \mathrm{H}), 7.32(\mathrm{~d}, J=8.2 \mathrm{~Hz}, 1 \mathrm{H}), 7.25(\mathrm{td}, J=7.2$, $0.8 \mathrm{~Hz}, 1 \mathrm{H}), 7.15-7.09(\mathrm{~m}, 2 \mathrm{H}), 6.82(\mathrm{~s}, 1 \mathrm{H}), 6.67-6.61(\mathrm{~m}, 2 \mathrm{H}), 5.64(\mathrm{dd}, J=1.2,1.21 \mathrm{H}), 3.80$ $(\mathrm{s}, 3 \mathrm{H}), 3.79-3.72(\mathrm{~m}, 1 \mathrm{H}), 3.76(\mathrm{~s}, 3 \mathrm{H}), 2.67-2.61(\mathrm{~m}, 2 \mathrm{H}), 2.15-2.01(\mathrm{~m}, 5 \mathrm{H}), 1.84-1.73(\mathrm{~m}, 4 \mathrm{H})$, $1.72-1.62(\mathrm{~m}, 1 \mathrm{H})$.

${ }^{13} \mathrm{C}$ NMR $\left(\mathrm{CDCl}_{3}, 101 \mathrm{MHz}\right): \delta 161.6(\mathrm{~d}, J=243.4 \mathrm{~Hz}), 159.1(\mathrm{~d}, J=10.8 \mathrm{~Hz}), 137.9,137.4,130.9$ $(\mathrm{d}, J=7.2 \mathrm{~Hz}), 127.2,126.3,124.9,121.5,121.4(\mathrm{~d}, J=16.6 \mathrm{~Hz}), 120.1,119.5,118.6,109.6(\mathrm{~d}, J$ = 3.1 Hz), 109.3, $101.6(\mathrm{~d}, J=26.2 \mathrm{~Hz}), 55.6,37.7,32.9,32.7,30.5,28.6,28.6,28.2$ (d, J = 1.7 $\mathrm{Hz}), 21.5$.

${ }^{19} \mathrm{~F}$ NMR $\left(\mathrm{CDCl}_{3}, 376 \mathrm{MHz}\right): \delta-116.58$. 
IR (Diamond-ATR, neat) $\widetilde{\boldsymbol{v}}_{\max }: 2928,2855,1625,1584,1506,1325,1134,1032,948,832$.

EA calcd. for $\mathrm{C}_{25} \mathrm{H}_{28}$ FNO: C, 79.54; $\mathrm{H}, 7.48$. Found: $\mathrm{C}, 79.28 ; \mathrm{H}, 7.51$.

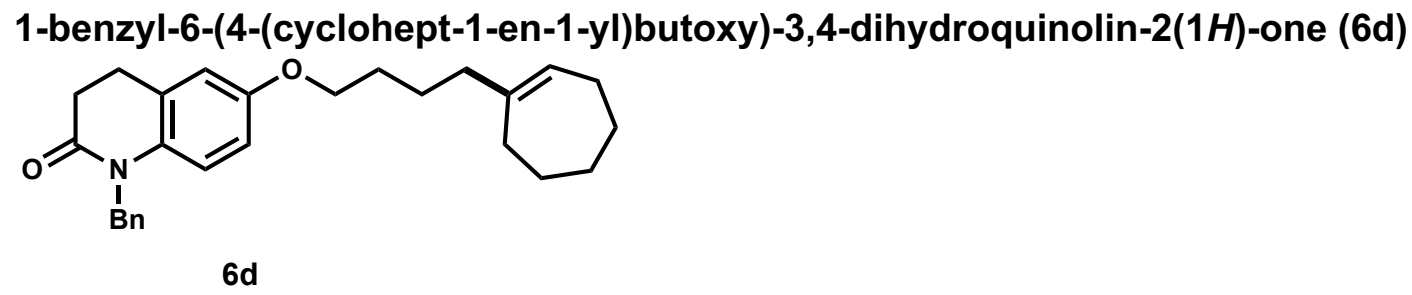

Prepared according to a modified General Procedure C using 1-benzyl-6-(but-3-en-1-yloxy)-3,4dihydroquinolin-2(1H)-one (SI-11c) $(154 \mathrm{mg}, 0.50 \mathrm{mmol}, 1.0$ equiv), cyclohept-1-en-1-yl trifluoromethanesulfonate (SI-2h) (183 mg, $0.75 \mathrm{mmol}, 1.5$ equiv), Cul (2.9 mg, $15 \mu \mathrm{mol}, 3.0$ mol\%), ( \pm )-DTBM-SEGPHOS (L1) $(20.6 \mathrm{mg}, 18.0 \mu \mathrm{mol}, 3.5 \mathrm{~mol} \%)$, and Pd(cinnamyl)(dppbz)(Cl) (10.6 mg, $15.0 \mu \mathrm{mol}, 3.0 \mathrm{~mol} \%$ ). The residue was purified by automated flash column chromatography on silica gel $\left(80 \mathrm{~g} \mathrm{SiO}_{2}\right.$, gradient elution: hexane to $5 \%$ EtOAc in hexane) to yield 6d ( $1^{\text {st }}$ run: $139 \mathrm{mg}, 69 \% ; 2^{\text {nd }}$ run: $\left.150 \mathrm{mg}, 74 \%\right)$ as a tan solid.

${ }^{1} \mathrm{H}$ NMR $\left(\mathrm{CDCl}_{3}, 400 \mathrm{MHz}\right): \delta 7.32-7.27(\mathrm{~m}, 2 \mathrm{H}), 7.25-7.18(\mathrm{~m}, 3 \mathrm{H}), 6.77(\mathrm{~d}, J=8.9 \mathrm{~Hz}, 1 \mathrm{H})$, $6.73(\mathrm{~d}, J=2.9 \mathrm{~Hz}, 1 \mathrm{H}), 6.61(\mathrm{dd}, J=8.9,2.9 \mathrm{~Hz}, 1 \mathrm{H}), 5.54(\mathrm{t}, J=6.4 \mathrm{~Hz}, 1 \mathrm{H}), 5.15(\mathrm{~s}, 2 \mathrm{H}), 3.89$ $(\mathrm{t}, J=6.5 \mathrm{~Hz}, 2 \mathrm{H}), 2.94(\mathrm{dd}, J=8.8,5.8 \mathrm{~Hz}, 2 \mathrm{H}), 2.77(\mathrm{dd}, J=8.7,5.8 \mathrm{~Hz}, 2 \mathrm{H}), 2.11-1.98$ (m, $6 \mathrm{H}), 1.76-1.68(\mathrm{~m}, 4 \mathrm{H}), 1.56-1.41(\mathrm{~m}, 6 \mathrm{H})$.

${ }^{13} \mathrm{C} \mathrm{NMR}\left(\mathrm{CDCl}_{3}, 101 \mathrm{MHz}\right): \delta 170.3,155.0,144.4,137.3,133.3,128.8,127.9,127.1,126.5,126.4$, 116.6, 114.6, 112.6, 68.3, 46.3, 39.9, 32.8, 32.8, 32.0, 28.9, 28.4, 27.5, 27.0, 26.0, 24.3.

IR (Diamond-ATR, neat) $\widetilde{\boldsymbol{v}}_{\text {max }}:$ 2931, 1606, 1508, 1487, 1440, 1243, 1035, 937, 807.

HRMS (DART) m/z: [M+H] ${ }^{+}$calcd. for $\mathrm{C}_{27} \mathrm{H}_{34} \mathrm{NO}_{2}{ }^{+}:$404.2584. Found: 404.2579.

Melting Point $\left({ }^{\circ} \mathrm{C}\right): 50-52$.

4-(2-(4-((3S,6R)-6-isopropyl-3-methylcyclohex-1-en-1-yl)butoxy)phenyl)morpholine (6e)<smiles>CC(C)C1CC[C@@H](C)C=C1CCCCOc1ccccc1N1CCOCC1</smiles>

$6 e$

Prepared according to a modified General Procedure C using 4-(2-(but-3-en-1yloxy)phenyl)morpholine SI-11e (117 mg, $0.500 \mathrm{mmol}, 1.0$ equiv), 3-isopropyl-6-methylcyclohex1-en-1-yl trifluoromethanesulfonate (SI-2m) $(215 \mathrm{mg}, 0.750 \mathrm{mmol}, 1.5$ equiv), Cul (2.9 mg, 15 $\mu \mathrm{mol}, 3.0 \mathrm{~mol} \%), \quad( \pm)$-DTBM-SEGPHOS (L1) $(20.6 \mathrm{mg}, 18.0 \mu \mathrm{mol}, 3.5 \mathrm{~mol} \%)$, and $\mathrm{Pd}($ cinnamyl)(dppbz)(Cl) $(10.6 \mathrm{mg}, 15.0 \mu \mathrm{mol}, 3.0 \mathrm{~mol} \%)$. The residue was purified by automated flash column chromatography on silica gel $\left(50 \mathrm{~g} \mathrm{SiO}_{2}\right.$, gradient elution: hexane to $5 \% \mathrm{EtOAc}$ in hexane) to yield $6 \mathrm{e}\left(1^{\text {st }}\right.$ run: $127 \mathrm{mg}, 68 \% ; 2^{\text {nd }}$ run: $\left.129 \mathrm{mg}, 69 \%\right)$ as a tan oil.

${ }^{1}$ H NMR $\left(\mathrm{CDCl}_{3}, 400 \mathrm{MHz}\right): \delta 7.02-6.95(\mathrm{~m}, 1 \mathrm{H}), 6.92(\mathrm{ad}, \mathrm{J}=3.6 \mathrm{~Hz}, 2 \mathrm{H}), 6.87$ (d, J = $7.9 \mathrm{~Hz}$, $1 \mathrm{H}), 5.33(\mathrm{~s}, 1 \mathrm{H}), 4.01(\mathrm{t}, J=6.4 \mathrm{~Hz}, 2 \mathrm{H}), 3.88(\mathrm{dd}, J=4.5,4.5 \mathrm{~Hz}, 4 \mathrm{H}), 3.10(\mathrm{dd}, J=4.5,4.5 \mathrm{~Hz}$, $4 \mathrm{H}), 2.20-2.11(\mathrm{~m}, 1 \mathrm{H}), 2.10-2.00(\mathrm{~m}, 3 \mathrm{H}), 1.96-1.73(\mathrm{~m}, 4 \mathrm{H}), 1.71-1.58(\mathrm{~m}, 2 \mathrm{H}), 1.56-1.44(\mathrm{~m}$, $1 \mathrm{H}), 1.34-1.22(\mathrm{~m}, 1 \mathrm{H}), 1.01-0.90(\mathrm{~m}, 7 \mathrm{H}), 0.70(\mathrm{~d}, J=6.6 \mathrm{~Hz}, 3 \mathrm{H})$. 
${ }^{13} \mathrm{C}$ NMR $\left(\mathrm{CDCl}_{3}, 101 \mathrm{MHz}\right): \delta 151.8,141.3,139.1,131.1,123.1,121.1,118.1,112.5,68.1,67.4$, $51.3,41.9,34.7,31.7,31.0,29.3,27.6,24.8,22.6,21.8,21.0,15.9$.

IR (Diamond-ATR, neat) $\widetilde{v}_{\max }$ : 2952, 2851, 1500, 1447, 1376, 1237, 1119, 1045, 934, 851.

Specific Rotation $[\alpha]^{23}$ : $+4.4\left(c=1.0, \mathrm{CHCl}_{3}\right)$.

EA calcd. for $\mathrm{C}_{24} \mathrm{H}_{37} \mathrm{NO}_{2}$ : C, 77.58; $\mathrm{H}, 10.04$. Found: $\mathrm{C}, 77.79 ; \mathrm{H}, 10.19$.

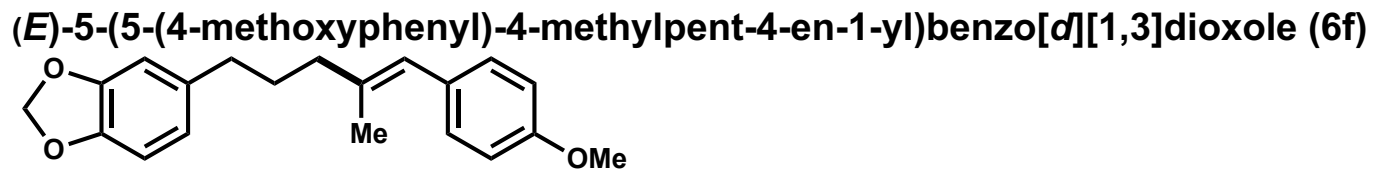

$6 \mathbf{f}$

Prepared according to a modified General Procedure C using safrole $(81 \mathrm{mg}, 0.50 \mathrm{mmol}, 1.0$ equiv), (E)-1-(4-methoxyphenyl)prop-1-en-1-yl trifluoromethanesulfonate (SI-2r) (220 mg, 0.75 mmol, 1.5 equiv), Cul (2.9 mg, $15 \mu \mathrm{mol}, 3.0 \mathrm{~mol} \%)$, ( \pm )-DTBM-SEGPHOS (L1) (20.6 mg, 18.0 $\mu \mathrm{mol}, 3.5 \mathrm{~mol} \%)$, and $\mathrm{Pd}($ cinnamyl)(dppbz)(Cl) $(10.6 \mathrm{mg}, 15.0 \mu \mathrm{mol}, 3.0 \mathrm{~mol} \%)$. The residue was purified by automated flash column chromatography on silica gel (50 $\mathrm{g} \mathrm{SiO}_{2}$, gradient elution: hexane to $5 \%$ EtOAc in hexane) to yield $6 f\left(1^{\text {st }}\right.$ run: $115 \mathrm{mg}, 74 \% ; 2^{\text {nd }}$ run: $\left.109 \mathrm{mg}, 70 \%\right)$ as a colorless oil.

${ }^{1} \mathrm{H} \mathrm{NMR}\left(\mathrm{CDCl}_{3}, 400 \mathrm{MHz}\right): \delta 7.18(\mathrm{~d}, J=8.7 \mathrm{~Hz}, 2 \mathrm{H}), 6.87(\mathrm{~d}, J=8.7 \mathrm{~Hz}, 2 \mathrm{H}), 6.77-6.70(\mathrm{~m}, 2 \mathrm{H})$, $6.66(\mathrm{dd}, J=7.9,1.7 \mathrm{~Hz}, 1 \mathrm{H}), 6.22(\mathrm{~s}, 1 \mathrm{H}), 5.93(\mathrm{~s}, 2 \mathrm{H}), 3.81(\mathrm{~s}, 3 \mathrm{H}), 2.58(\mathrm{t}, J=7.7 \mathrm{~Hz}, 2 \mathrm{H}), 2.19$ (t, $J=7.6 \mathrm{~Hz}, 2 \mathrm{H}), 1.85(\mathrm{~s}, 3 \mathrm{H}), 1.83-1.76(\mathrm{~m}, 2 \mathrm{H})$.

${ }^{13} \mathrm{C} \mathrm{NMR}\left(\mathrm{CDCl}_{3}, 101 \mathrm{MHz}\right): \delta 157.5,147.3,145.3,137.0,136.2,131.0,129.7,124.4,121.0,113.3$, 108.7, 107.9, 100.5, 55.1, 39.9, 35.0, 29.8, 17.5 .

IR (Diamond-ATR, neat) $\widetilde{\boldsymbol{v}}_{\text {max }}$ : 2931, 1606, 1508, 1487, 1440, 1243, 1035, 937, 807.

HRMS (DART) m/z: $[\mathrm{M}+\mathrm{H}]^{+}$calcd. for $\mathrm{C}_{20} \mathrm{H}_{23} \mathrm{O}_{3}{ }^{+}:$311.1642. Found: 311.1644.

\section{2-((6-methyl-7,7-diphenylhept-6-en-1-yl)oxy)benzo[d]thiazole (6g)}

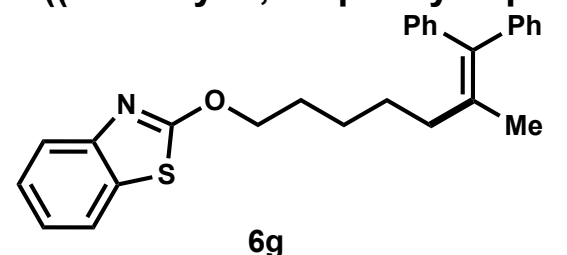

$6 \mathrm{~g}$

Prepared according to a modified General Procedure C using 2-(pent-4-en-1yloxy)benzo[d]thiazole (SI-11d) (110 mg, $0.50 \mathrm{mmol}, 1.0$ equiv), 1,1-diphenylprop-1-en-2-yl trifluoromethanesulfonate (SI-2n)(260 mg, $0.75 \mathrm{mmol}, 1.5$ equiv), Cul (2.9 mg, $15 \mu \mathrm{mol}, 3.0$ mol\%), ( \pm )-DTBM-SEGPHOS (L1) (20.6 mg, $18.0 \mu \mathrm{mol}, 3.5 \mathrm{~mol} \%)$, and Pd(cinnamyl)(dppbz)(Cl) $(10.6 \mathrm{mg}, 15.0 \mu \mathrm{mol}, 3.0 \mathrm{~mol} \%)$ at $45^{\circ} \mathrm{C}$. The residue was purified by automated flash column chromatography on silica gel (50 $\mathrm{g} \mathrm{SiO}_{2}$, gradient elution: hexane to $30 \% \mathrm{CH}_{2} \mathrm{Cl}_{2}$ in hexane) to yield $6 \mathrm{~g}$ ( $1^{\text {st }}$ run: $146 \mathrm{mg}, 71 \% ; 2^{\text {nd }}$ run: $\left.154 \mathrm{mg}, 75 \%\right)$ as a colorless solid.

${ }^{1} \mathrm{H}$ NMR $\left(\mathrm{CDCl}_{3}, 400 \mathrm{MHz}\right): \delta 7.73(\mathrm{~d}, J=8.0 \mathrm{~Hz}, 1 \mathrm{H}), 7.66(\mathrm{~d}, J=8.0 \mathrm{~Hz}, 1 \mathrm{H}), 7.39(\mathrm{td}, J=8.3$, $1.0 \mathrm{~Hz}, 1 \mathrm{H}), 7.33-7.27(\mathrm{~m}, 4 \mathrm{H}), 7.25-7.15(\mathrm{~m}, 7 \mathrm{H}), 4.55(\mathrm{t}, J=6.6 \mathrm{~Hz}, 2 \mathrm{H}), 2.20$ (dd, J = 8.9, 6.5 $\mathrm{Hz}, 2 \mathrm{H}), 1.84-1.75(\mathrm{~m}, 2 \mathrm{H}), 1.82(\mathrm{~s}, 3 \mathrm{H}), 1.64-1.54(\mathrm{~m}, 2 \mathrm{H}), 1.49-1.39(\mathrm{~m}, 2 \mathrm{H})$. 
${ }^{13} \mathrm{C} \mathrm{NMR}\left(\mathrm{CDCl}_{3}, 101 \mathrm{MHz}\right): \delta 173.2,149.6,143.5,143.4,138.1,134.7,132.5,132.0,130.2,129.7$, 129.6, 128.4, 128.1, 128.0, 126.2, 126.2, 126.1, 123.5, 121.4, 120.8, 72.1, 35.2, 28.7, 28.0, 25.6, 19.7 .

IR (Diamond-ATR, neat) $\widetilde{\boldsymbol{v}}_{\max }: 2928,2856,1729,1659,1597,1533,1442,1249,1215,1067,726$. EA calcd. for $\mathrm{C}_{27} \mathrm{H}_{27} \mathrm{NOS}$ : C, 78.41; $\mathrm{H}, 6.58$. Found: $\mathrm{C}, 78.43 ; \mathrm{H}, 6.55$.

Melting Point $\left({ }^{\circ} \mathrm{C}\right): 58-61$.

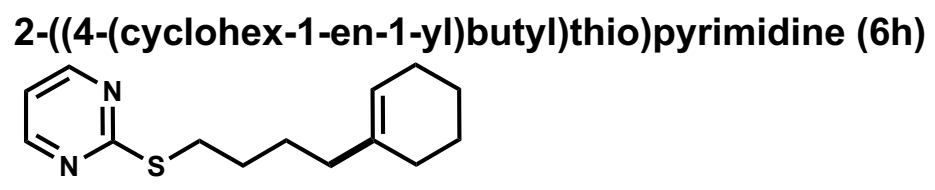

6h

Prepared according to a modified General Procedure C using 2-(but-3-en-1-ylthio)pyrimidine (SI11f) (83 mg, $0.50 \mathrm{mmol}, 1.0$ equiv), cyclohex-1-en-1-yl trifluoromethanesulfonate (2a) (170 mg, $0.75 \mathrm{mmol}, 1.5$ equiv), Cul (2.9 mg, $15 \mu \mathrm{mol}, 3.0 \mathrm{~mol} \%)$, ( \pm )-DTBM-SEGPHOS (L1) (20.6 mg, 18.0 $\mu \mathrm{mol}, 3.5 \mathrm{~mol} \%)$, and $\mathrm{Pd}($ cinnamyl)(dppbz)(Cl) $(10.6 \mathrm{mg}, 15.0 \mu \mathrm{mol}, 3.0 \mathrm{~mol} \%)$. The residue was purified by automated flash column chromatography on silica gel $\left(50 \mathrm{~g} \mathrm{SiO}_{2}\right.$, gradient elution: hexane to $5 \%$ EtOAc in hexane) to yield $6 \mathrm{~h}\left(1^{\text {st }}\right.$ run: $83 \mathrm{mg}, 67 \% ; 2^{\text {nd }}$ run: $\left.86 \mathrm{mg}, 69 \%\right)$ as a yellow oil.

${ }^{1} \mathrm{H}$ NMR $\left(\mathrm{CDCl}_{3}, 400 \mathrm{MHz}\right): \delta 8.49(\mathrm{~d}, J=4.8 \mathrm{~Hz}, 2 \mathrm{H}), 6.93(\mathrm{t}, J=4.8 \mathrm{~Hz}, 1 \mathrm{H}), 5.41-5.36(\mathrm{~m}, 1 \mathrm{H})$, $3.14(\mathrm{t}, J=7.3 \mathrm{~Hz}, 2 \mathrm{H}), 1.99-1.93(\mathrm{~m}, 4 \mathrm{H}), 1.92-1.87(\mathrm{~m}, 2 \mathrm{H}), 1.75-1.66(\mathrm{~m}, 2 \mathrm{H}), 1.63-1.48(\mathrm{~m}$, $6 \mathrm{H})$.

${ }^{13} \mathrm{C}$ NMR $\left(\mathrm{CDCl}_{3}, 101 \mathrm{MHz}\right): \delta$ 173.0, 157.3, 137.5, 121.2, 116.3, 37.6, 30.9, 28.8, 28.3, 27.0, 25.4, 23.1, 22.7.

IR (Diamond-ATR, neat) $\widetilde{v}_{\text {max }}$ : 2927, 2856, 1666, 1564, 1545, 1378, 1186, 798, 773.

HRMS (DART) m/z: [M+H] $]^{+}$calcd. for $\mathrm{C}_{14} \mathrm{H}_{21} \mathrm{~N}_{2} \mathrm{~S}^{+}:$249.1420. Found: 249.1427 . 


\subsection{Additional Hydroalkenylation Products and Data}

Scheme SI2: Additional Markovnikov olefin hydroalkenylation examples ${ }^{a}$<smiles>C=C(C)C1CCC(C)=C(C(C)c2ccccc2)C1</smiles>

$21 \%$<smiles>Cc1ccc2cc(C(C)C3=CCOCC3)ccc2n1</smiles>

$62 \%$

product was unstable<smiles>CC(C)C(=O)N1CC=C([C@@H](C)c2ccccc2)CC1</smiles>

$42 \%$

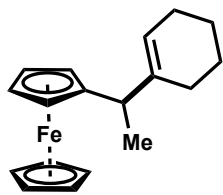

$77 \%$<smiles>COc1cccc(C2=C(C(C)c3ccc(CC(C)C)cc3)CCOC2)c1</smiles>

$30 \%$<smiles>CCNC(=O)c1ccc(C2=C(C(C)c3ccccc3)CCC2)cc1</smiles>

$68 \%$<smiles>C[C@H](C1=CCN(C(=O)c2ccccc2)CC1)c1ccc2c(c1)Cc1ccccc1-2</smiles>

$84 \%$

product was unstable<smiles>CCCNS(=O)(=O)c1ccc(C(C)C2=CCCCC2)cc1</smiles>

$0 \%$<smiles>COCCC(C1=CCCC1)c1ccc(Br)cc1</smiles>

$70 \%$

${ }^{a}$ Reactions performed according to General Procedure $\mathbf{C}$ using $0.2 \mathrm{mmol}$ olefin (1.0 equiv), 0.3 $\mathrm{mmol}$ triflate (1.5 equiv). Yields were determined by ${ }^{1} \mathrm{H}$ NMR spectroscopy of the crude reaction mixture, using 1,1,2,2-tetrachloroethane as an internal standard. 
Supporting Information

\section{References and Notes}

1. Reeves, D. C.; Rodriguez, S.; Lee, H.; Haddad, N.; Krishnamurthy, D.; Senanayake, C. H. Palladium Catalyzed Alkoxy- and Aminocarbonylation of Vinyl Tosylates. Org. Lett. 2011, 13, 2495-2497.

2. Graven, A.; Jørgensen, K. A.; Dahl, S.; Stanczak, A. Oxidative Halo-Decarboxylation of $\alpha$, $\beta$-Unsaturated Carboxylic Acids. J. Org. Chem. 1994, 59, 3543-3546.

3. Mohan, B.; Hwang, S.; Woo, H.; Park, K. H. Transition-metal free synthesis of diaryl vinyl selenides: a simple synthetic approach with high selectivity. Tetrahedron 2014, 70, 26992702.

4. Xie, L.; Zhen, X.; Huang, S.; Su, X.; Lin, M.; Li, Y. Photoinduced rearrangement of vinyl tosylates to $\beta$-ketosulfones. Green Chem. 2017, 19, 3530-3534.

5. Stadler, A.; von Schenck, H.; Vallin, K. S. A.; Larhed, M. Hallberg, A. Terminal Heck Vinylations of Chelating Vinyl Ethers. Adv. Synth. Cat. 2004, 346, 1773-1781.

6. Larock, R. C.; Tian, Q. Palladium-Catalyzed Annulation of Internal Alkynes by AreneContaining Vinylic lodides and Triflates. J. Org. Chem. 1998, 63, 2002-2009.

7. Lou, T. S.-B.; Bagley, S. W.; Willis, M. C. Cyclic Alkenylsulfonyl Fluorides: PalladiumCatalyzed Synthesis and Functionalization of Compact Multifunctional Reagents. Angew. Chem. Int. Ed. 2019, 58, 18859-18863.

8. Crisp, G. T.; Glink, P. T. Palladium-catalyzed Heck couplings of L-vinylglycine derivatives with vinyl and aryl halides and triflates. Tetrahedron 1992, 48, 3541-3556.

9. Ye, Y.; Takada, T.; Buchwald, S. L. Palladium-Catalyzed Fluorination of Cyclic Vinyl Triflates: Effect of TESCF 3 as an Additive. Angew. Chem. Int. Ed. 2016, 55, 15559-15563.

10. Grundl, M. A.; Kaster, A.; Beaulieu, E. D.; Trauner, D. Development of a Friedel-Crafts Triflation. Org. Lett. 2006, 8 5429-5432.

11. Paquette, L. A.; Sup Ra, C.; Edmonson, S. D. Regiocontrolled cyclohexenone annulation via acylation of a ketone carbonyl. J. Org. Chem. 1990, 55, 2443-2445.

12. Zhou, Y.; Bandar, J. S.; Buchwald, S. L. Enantioselective CuH-Catalyzed Hydroacylation Employing Unsaturated Carboxylic Acids as Aldehyde Surrogates. J. Am. Chem. Soc. 2017, 139, 8126-8129.

13. Liu, Y.; Zhang, M.; Tung, C.-H.; Wang, Y. TiO 2 Photocatalytic Cyclization Reactions for the Syntheses of Aryltetralones. ACS Catal. 2016, 6, 8389-8394.

14. Cao, H.; Jiang, H.; Feng, H.; Kwan, J. M. C.; Liu, X.; Wu, J. Photo-induced Decarboxylative Heck-Type Coupling of Unactivated Aliphatic Acids and Terminal Alkenes in the Absence of Sacrificial Hydrogen Acceptors. J. Am. Chem. Soc. 2018, 140, 16360-16367.

15. Takashi, I.; Shigeo, T. TRIBOLUMINESCENCE AND TRIBOPOLYMERIZATION OF 9ETHYL-3-VINYLCARBAZOLE. Chem. Lett. 1981, 10, 589-592.

16. Gribble, M. W.; Pirnot, M. T.; Bandar, J. S.; Liu, R. Y.; Buchwald, S. L. Asymmetric Copper Hydride-Catalyzed Markovnikov Hydrosilylation of Vinylarenes and Vinyl Heterocycles. J. Am. Chem. Soc. 2017, 139, 2192-2195.

17. Niu, D.; Buchwald, S. L. Design of Modified Amine Transfer Reagents Allows the Synthesis of a-Chiral Secondary Amines via CuH-Catalyzed Hydroamination. J. Am. Chem. Soc. 2015, 137, 9716-9721.

18. West, T. H.; Spoehrle, S. S. M.; Smith, A. D. Isothiourea-catalysed chemo- and enantioselective [2,3]-sigmatropic rearrangements of $N, N$-diallyl allylic ammonium ylides Tetrahedron 2017, 73, 4138-4149.

19. West, T. H.; Daniels, D. S. B.; Slawin, A. M. Z.; Smith, A. D. An Isothiourea-Catalyzed Asymmetric [2,3]-Rearrangement of Allylic Ammonium Ylides. J. Am. Chem. Soc. 2014, 136, 4476-4479.

20. Sanders, J. K. M.; Rowan, S. J. Macrocycles Derived from Cinchona Alkaloids: A Thermodynamic vs Kinetic Study. J. Org. Chem. 1998, 63, 1536-1546. 
21. Ye, Y.; Kim, S.-T.; Jeong, J.; Baik, M.-H.; Buchwald, S. L. CuH-Catalyzed Enantioselective Alkylation of Indole Derivatives with Ligand-Controlled Regiodivergence. J. Am. Chem. Soc. 2019, 141, 3901-3909.

22. Schuppe, A. W.; Borrajo-Calleja, G. M.; Buchwald, S. L. Enantioselective Olefin Hydrocyanation without Cyanide. J. Am. Chem. Soc. 2019, 141, 18668-18672.

23. Friis, S. D.; Pirnot, M. T.; Dupuis, L. N.; Buchwald, S. L. A Dual Palladium and Copper Hydride Catalyzed Approach for Alkyl-Aryl Cross-Coupling of Aryl Halides and Olefins. Angew. Chem. Int. Ed. 2017, 56, 7242-7246.

24. Fu, W. C.; So, C. M.; Chow, W. K. Yuen, O. Y.; Kwong, F. Y. Design of an Indolylphosphine Ligand for Reductive Elimination-Demanding Monoarylation of Acetone using Aryl Chlorides. Org. Lett. 2015, 17, 4612-4615.

25. The absolute configuration of compounds $3 \mathbf{a}$ was assigned by comparison to: Chen, Y.-G.; Shuai, B.; Xu, X.-T.; Li, Y.-Q.; Yang, Q.-L.; Qiu, H.; Zhang, K.; Fang, P.; Mei, T.-S. Nickelcatalyzed Enantioselective Hydroarylation and Hydroalkenylation of Styrenes. J. Am. Chem. Soc. 2019, 141, 3395-3399. This result is in line with our previous results on asymmetric olefin hydroarylation in which the transmetallation step is stereoretentive.

26. Piwinski, J. J.; Wong, J. K.; Chan, T. M.; Green, M. J.; Ganguly, A. K. Hydroxylated metabolites of loratadine: an example of conformational diastereomers due to atropisomerism. J. Org. Chem. 1990, 55, 3341-3350.

27. (a) Chandra, T.; Zebrowski, J. P. Hazards associated with laboratory scale hydrogenations. Chem. Health Saf. 2016, 23, 16-25 (b) National Research Council. Prudent Practices in the Laboratory: Handling and Management of Chemical Hazards, Updated Version. Washington, DC: The National Academies Press, 2011. https://doi.org/10.17226/12654. 


\section{Associated Analytical Data}

6.1. NMR Spectra of Starting Materials for Olefin Hydroalkenylation

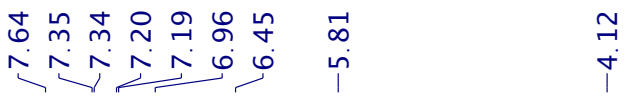

$\operatorname{Pd}($ cinnamyl $)(d p b b z)(C l)$

P1

${ }^{1} \mathrm{H}$ NMR, $400 \mathrm{MHz}, \mathrm{CDCl}_{3}$

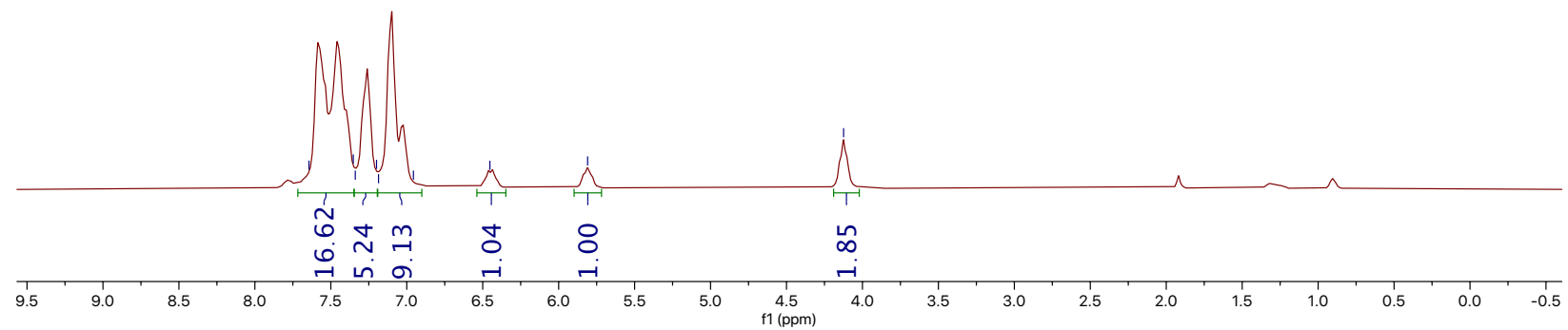



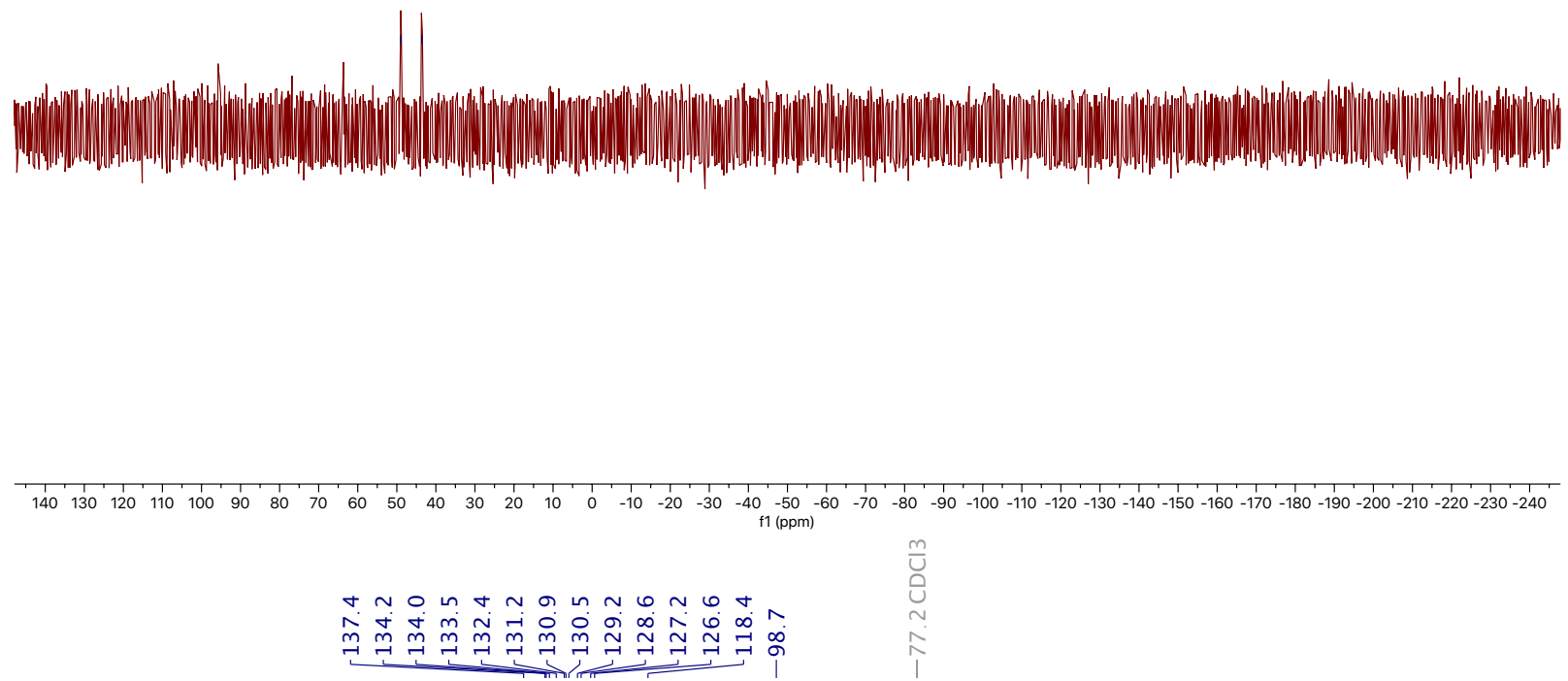

$\mathrm{Pd}($ cinnamyl $)(\mathrm{dpbbz})(\mathrm{Cl})$

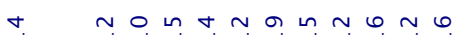

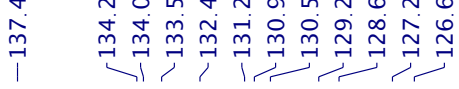

P1

${ }^{13} \mathrm{C}$ NMR, $101 \mathrm{MHz}, \mathrm{CDCl}_{3}$
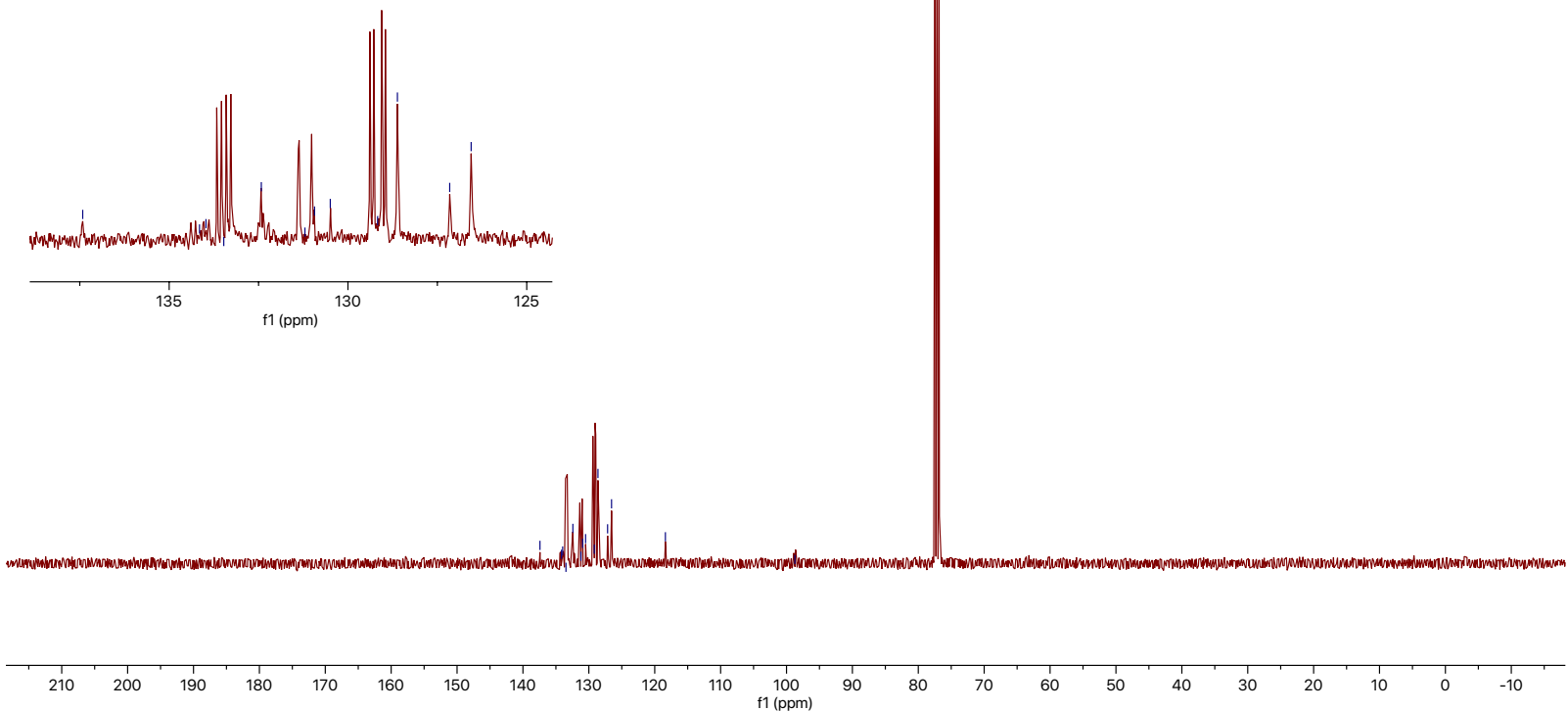
Supporting Information

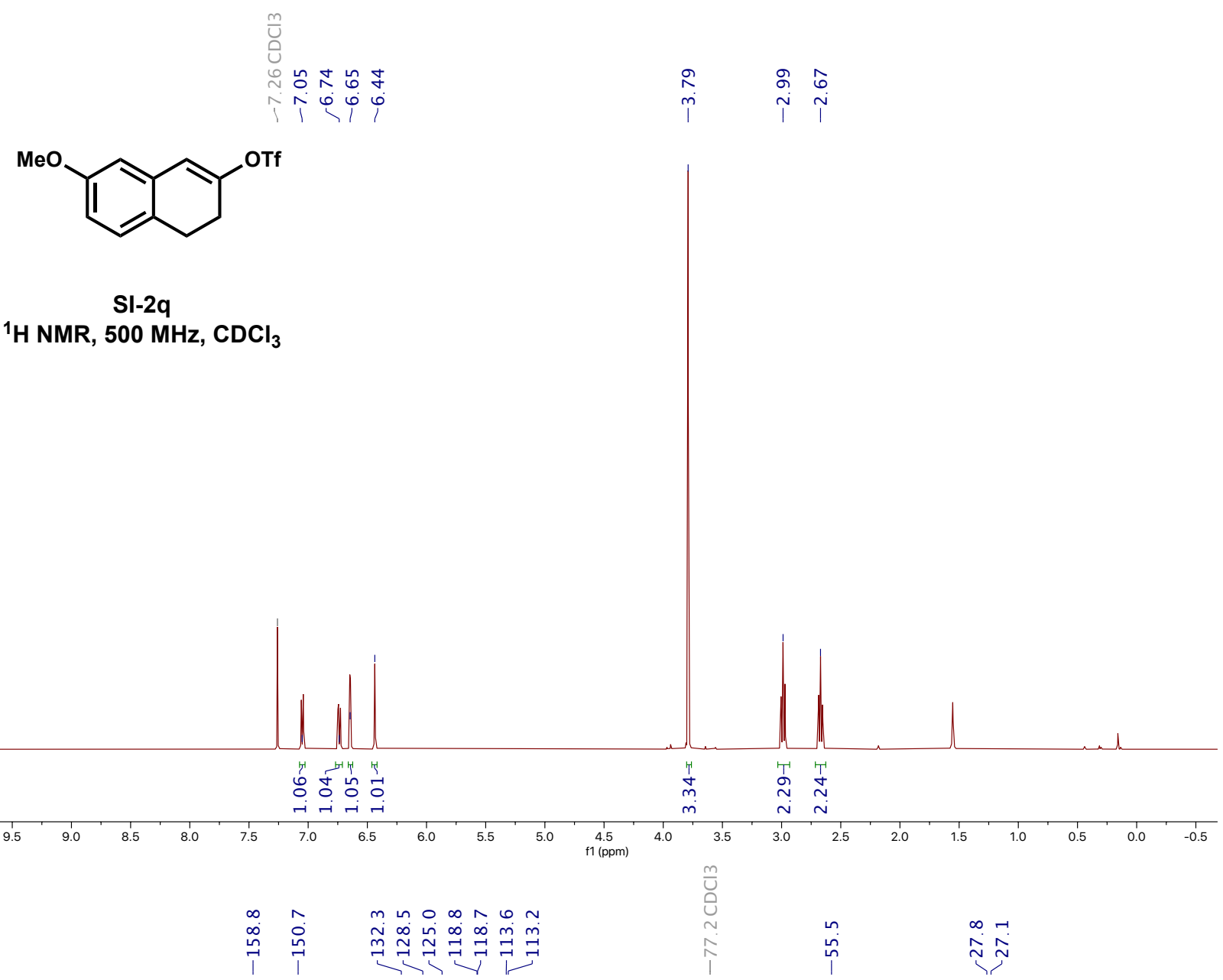<smiles>CCCOC1=Cc2cc(OC)ccc2CC1</smiles>

SI-2q

${ }^{13} \mathrm{C} \mathrm{NMR}, 126 \mathrm{MHz}, \mathrm{CDCl}_{3}$

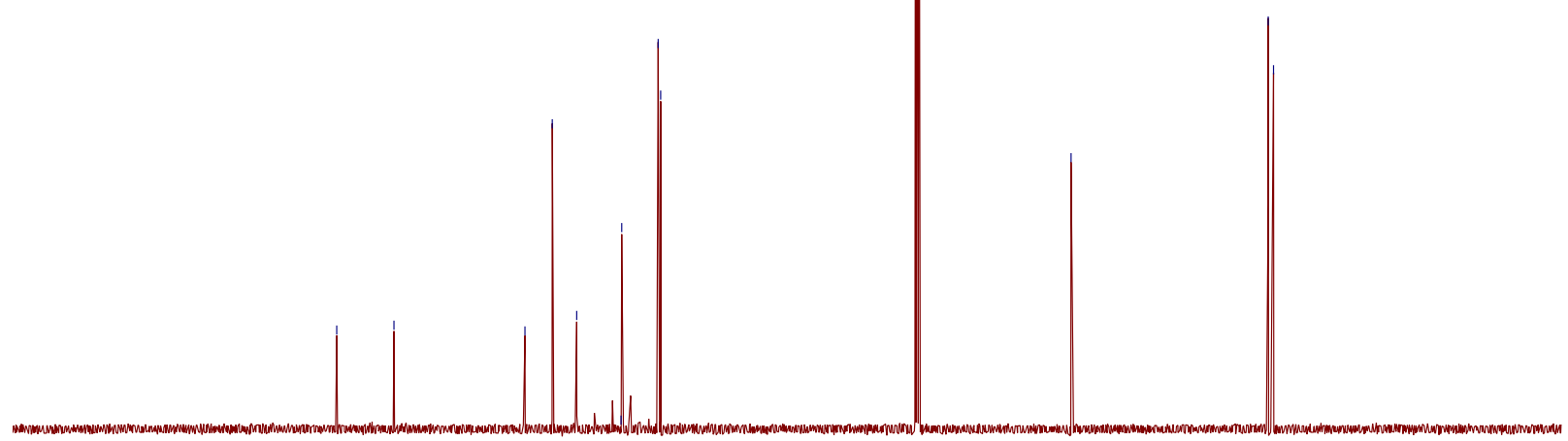


Supporting Information

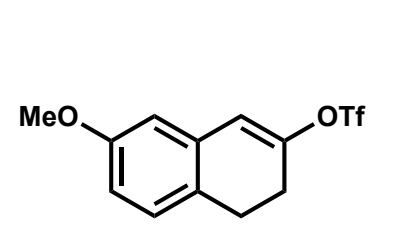

节

$\stackrel{m}{i}$

SI-2q

${ }^{19} \mathrm{~F} \mathrm{NMR}, 471 \mathrm{MHz}, \mathrm{CDCl}_{3}$

\section{}


Supporting Information
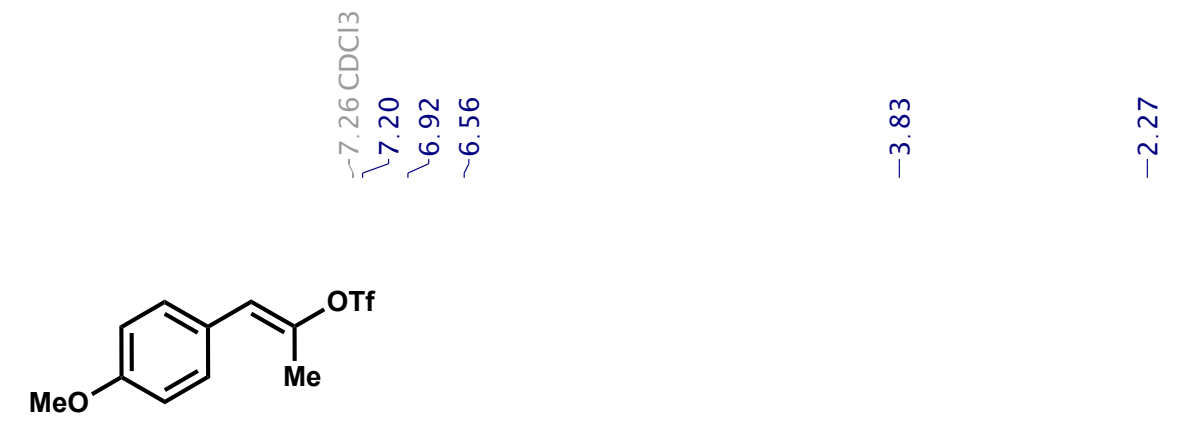

SI-2r

${ }^{1} \mathrm{H} \mathrm{NMR}, 400 \mathrm{MHz}, \mathrm{CDCl}_{3}$

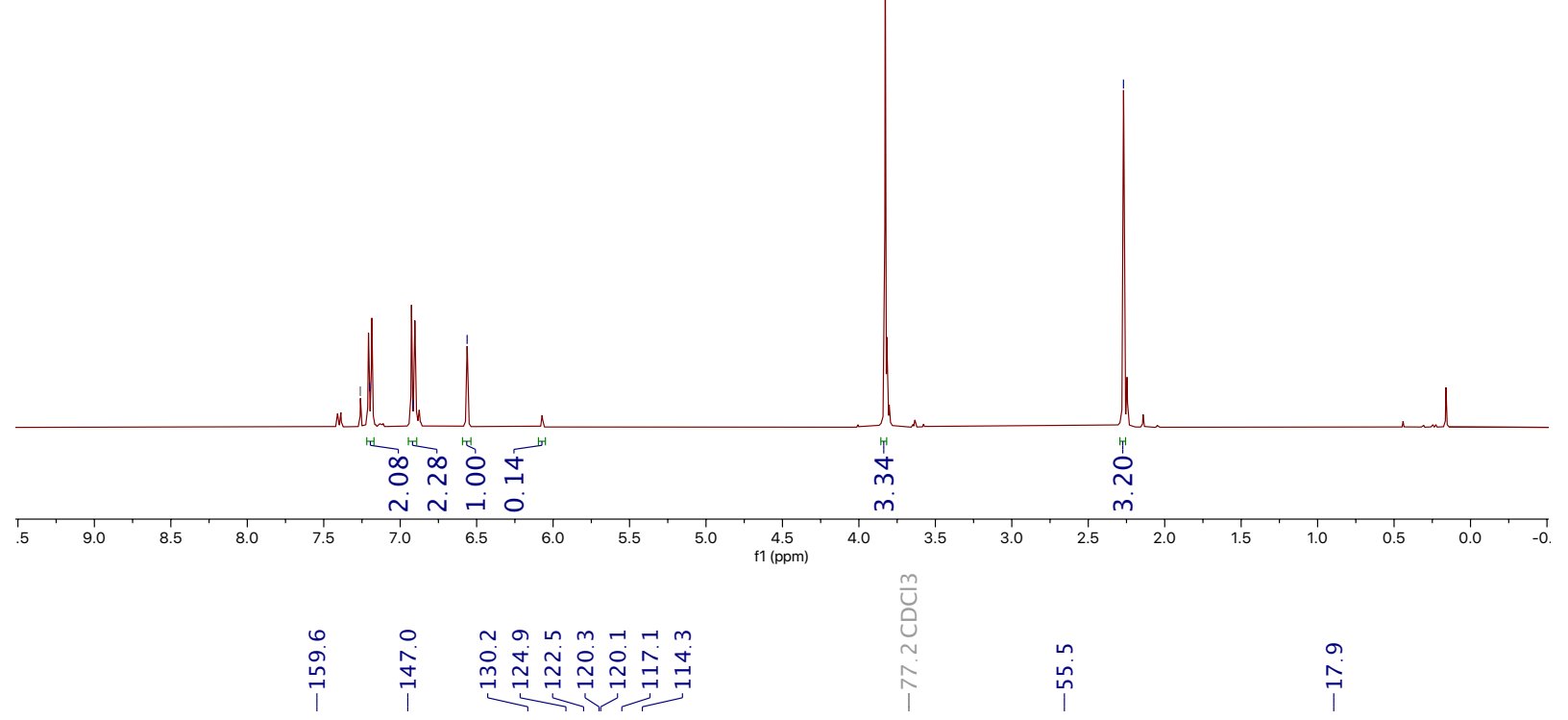<smiles>CO/C(=C/c1ccc(OC)cc1)[N+](=O)[O-]</smiles>

$\mathrm{SI}-2 \mathrm{r}$

${ }^{13} \mathrm{C}$ NMR, $101 \mathrm{MHz}, \mathrm{CDCl}_{3}$

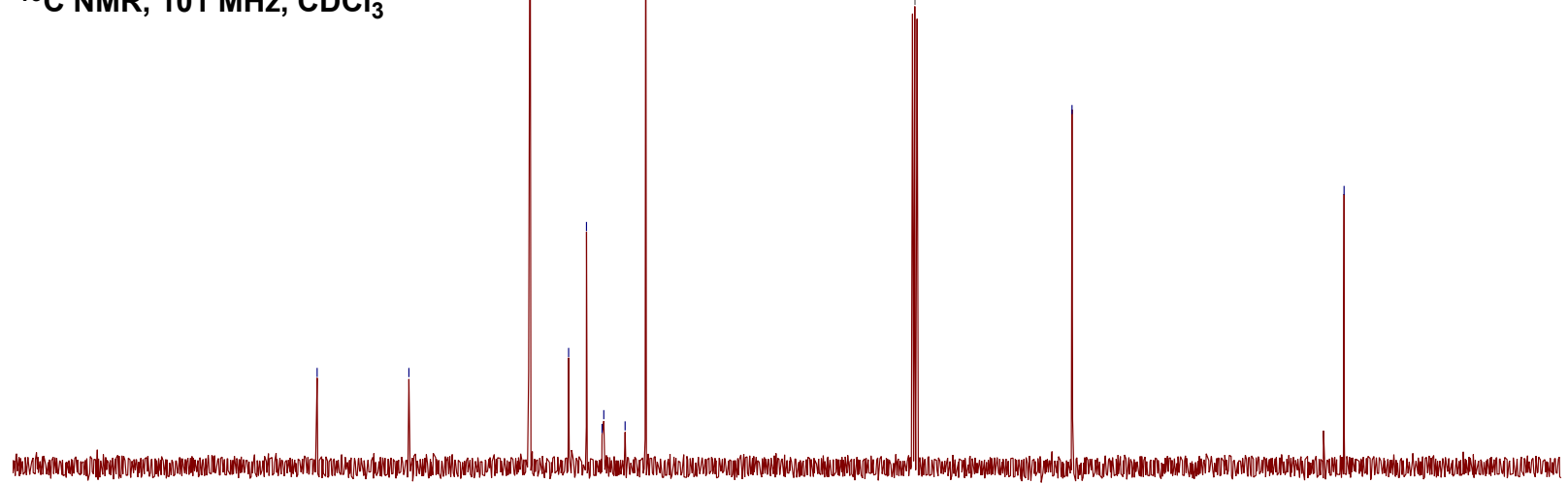

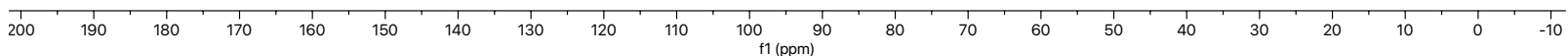


Supporting Information

$\infty$

$\stackrel{m}{i}$<smiles>CCO/C(C)=C/c1ccc(OC)cc1</smiles>

$\mathrm{SI}-2 \mathrm{r}$

${ }^{19} \mathrm{~F} \mathrm{NMR,}, 376 \mathrm{MHz}, \mathrm{CDCl}_{3}$
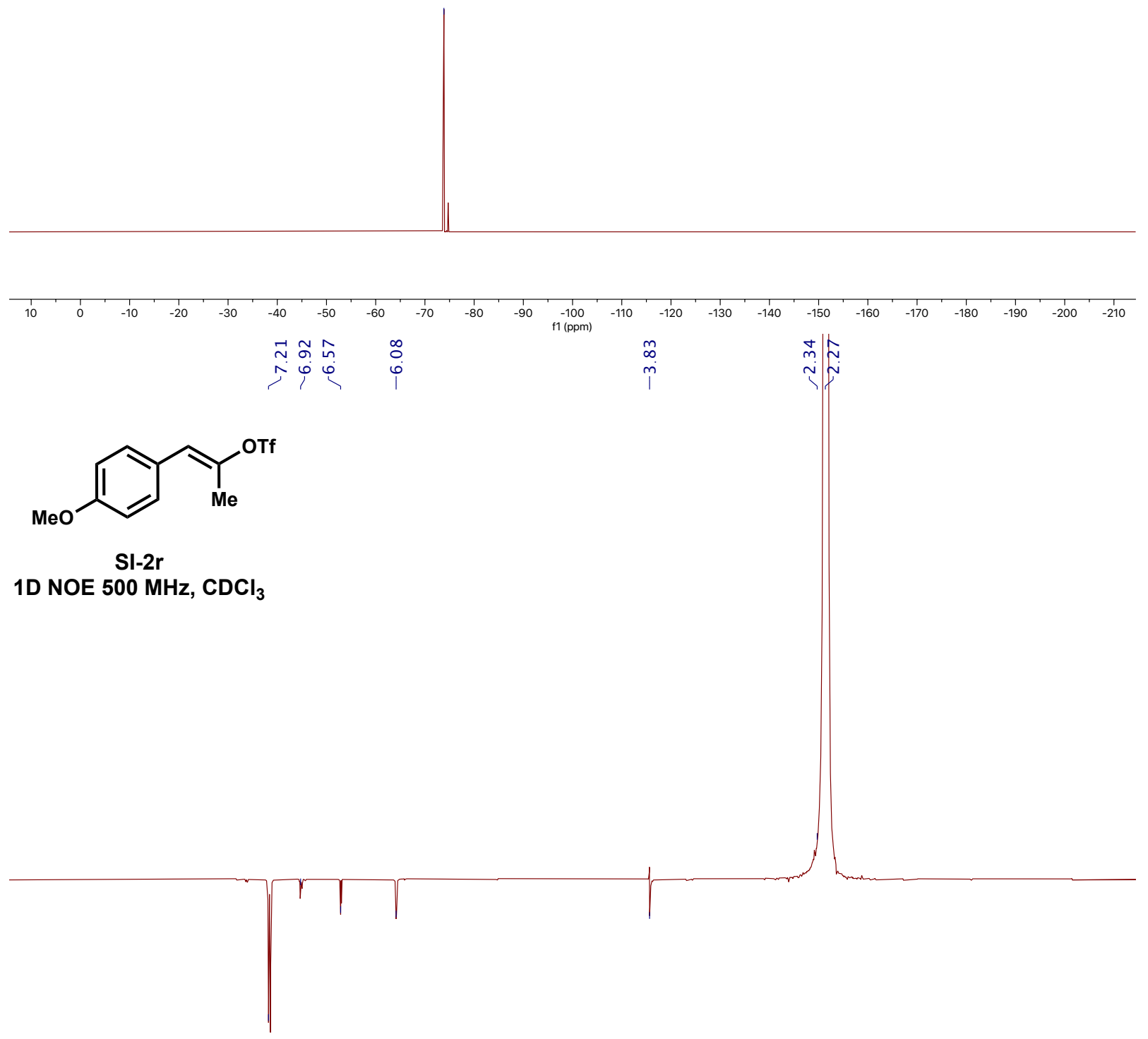

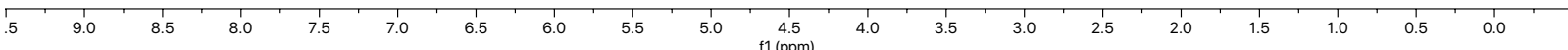


Supporting Information
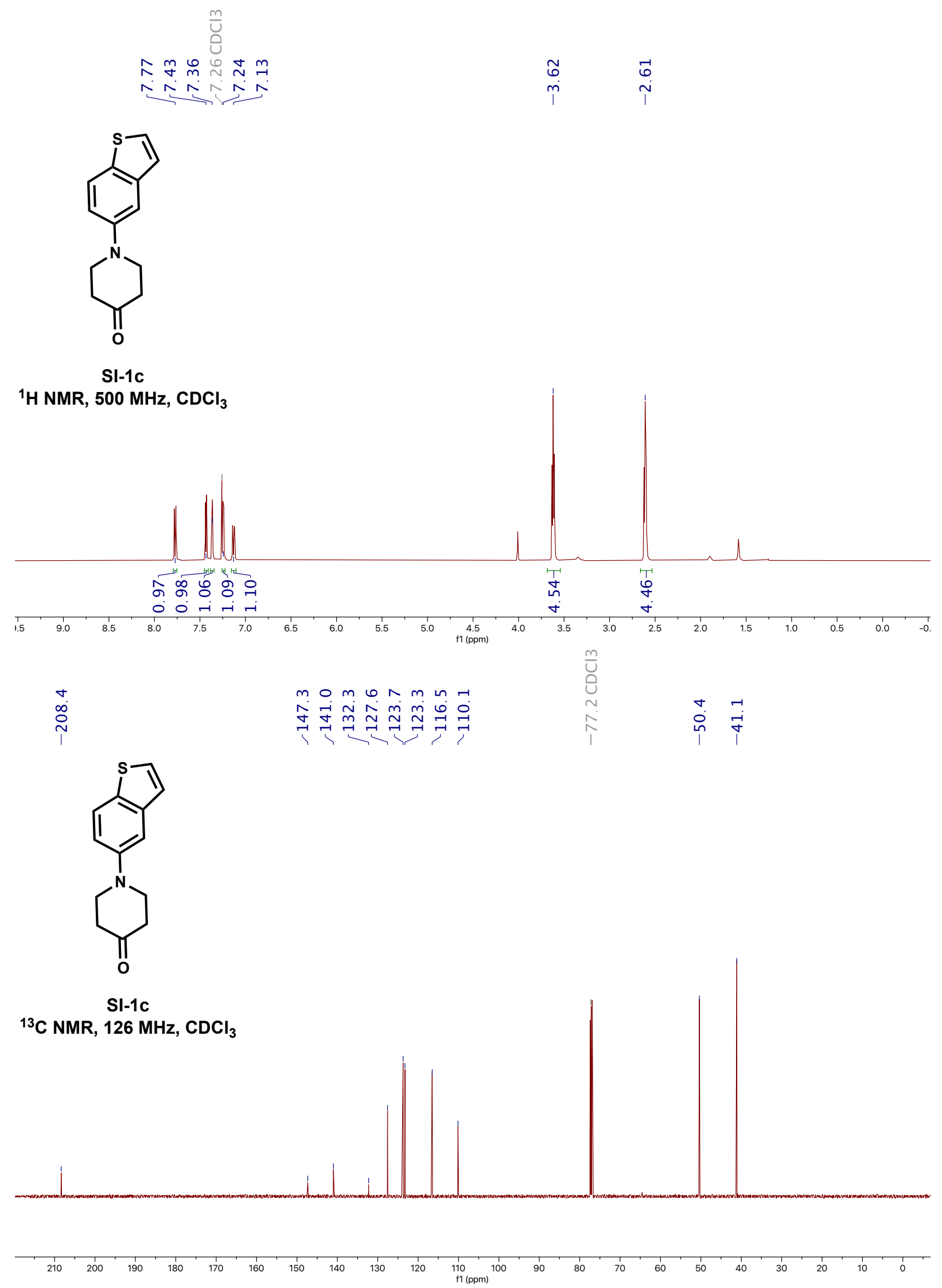
Supporting Information
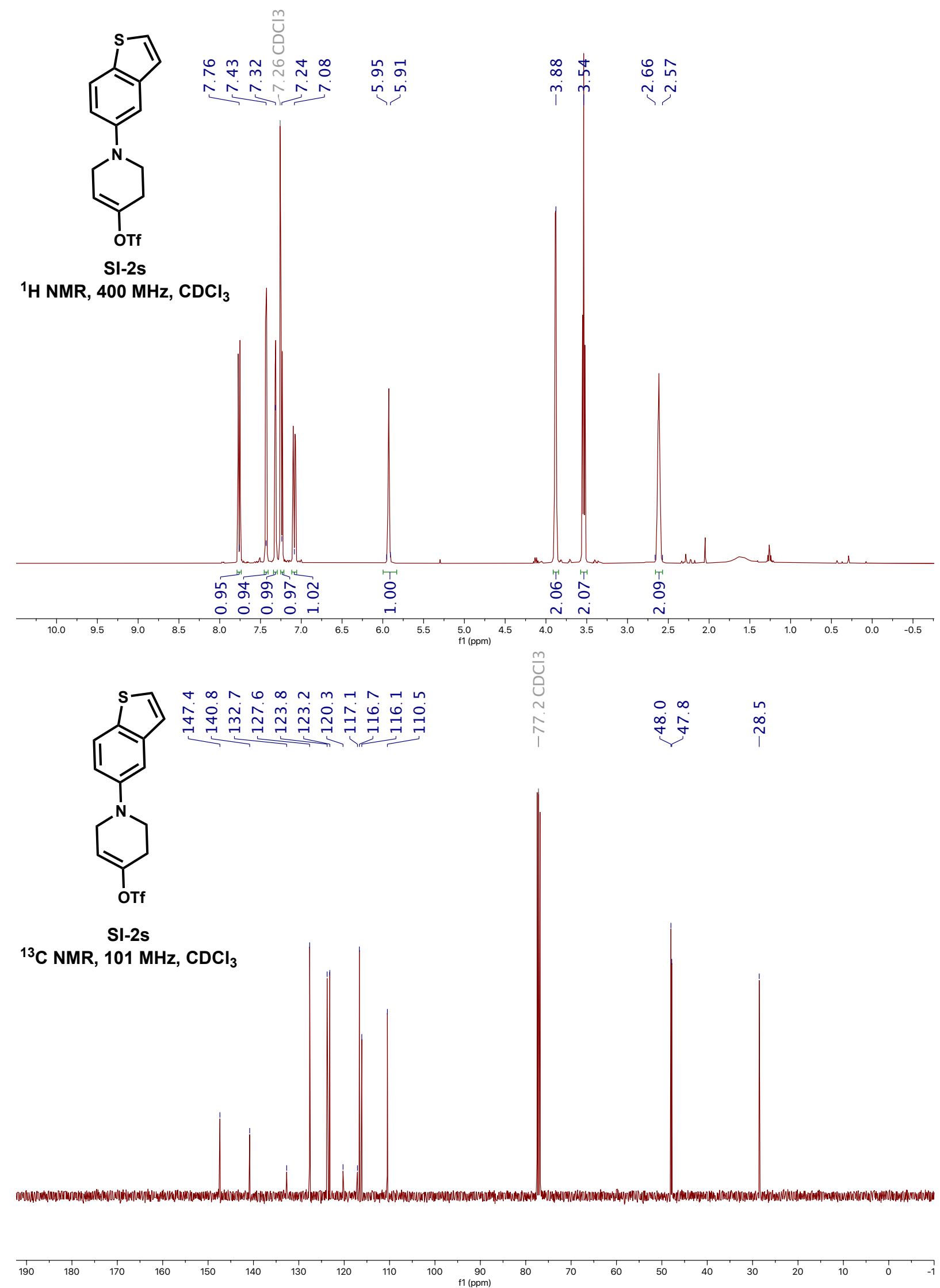
Supporting Information

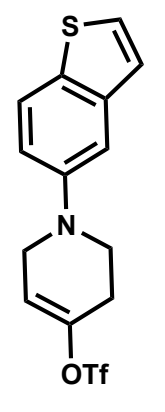

$\stackrel{m}{n}$

SI-2s

${ }^{19} \mathrm{~F}$ NMR, $471 \mathrm{MHz}, \mathrm{CDCl}_{3}$

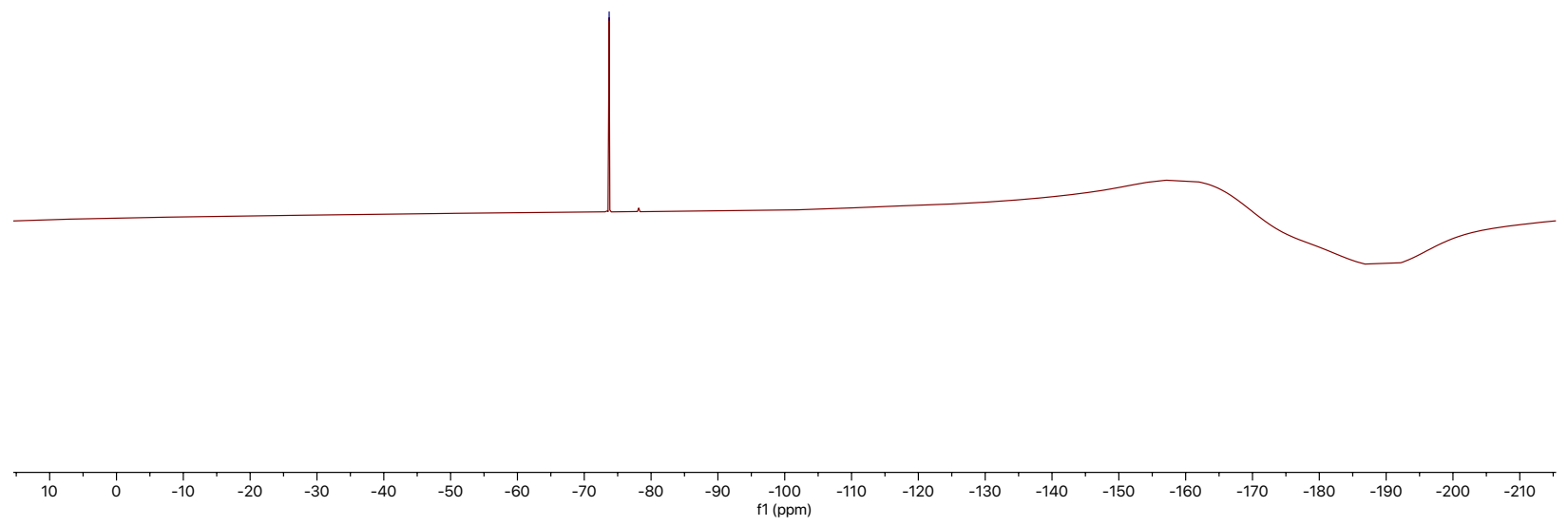


Supporting Information
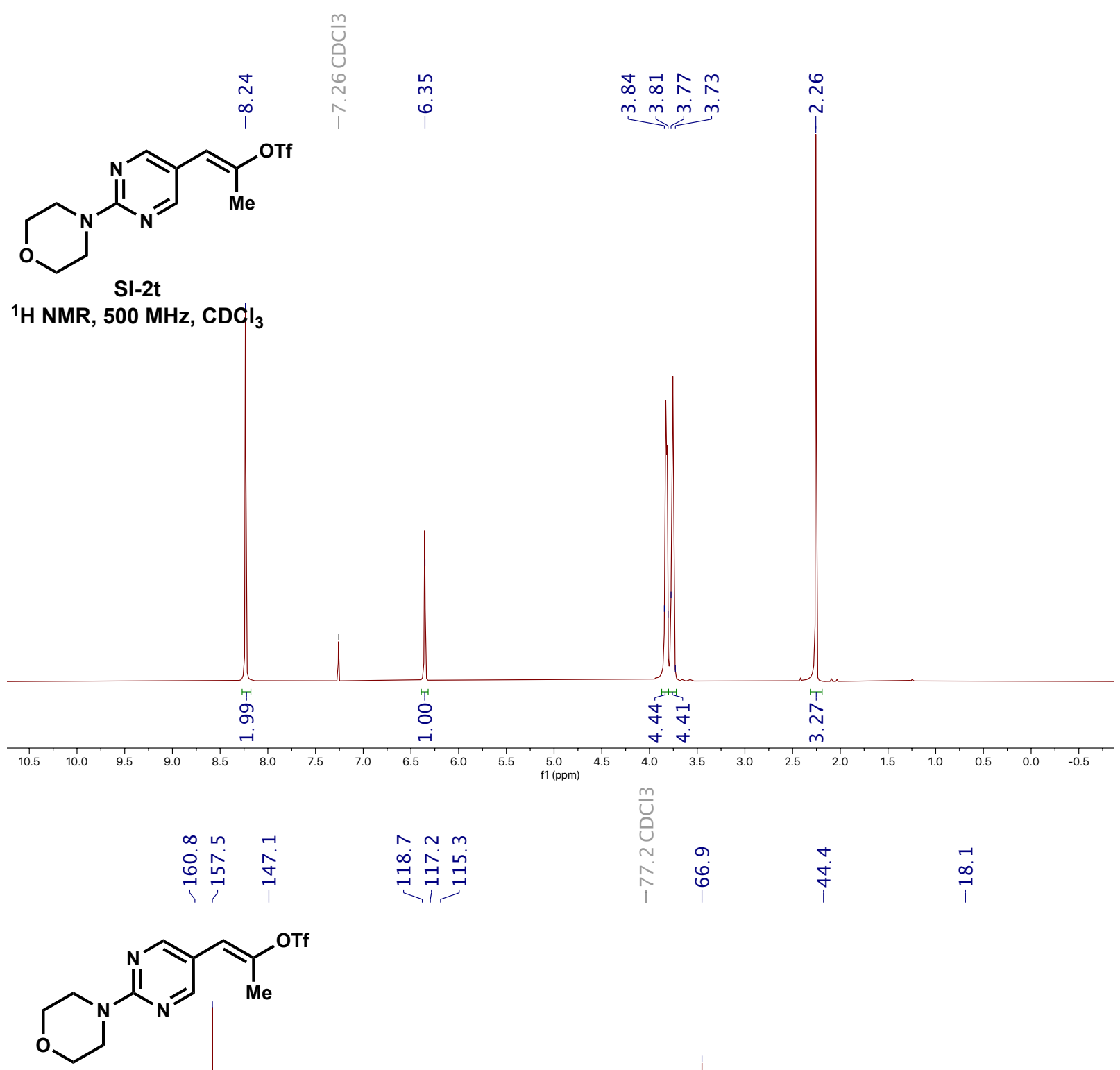

SI-2t

${ }^{13} \mathrm{C}$ NMR, $101 \mathrm{MHz}, \mathrm{CDCl}_{3}$
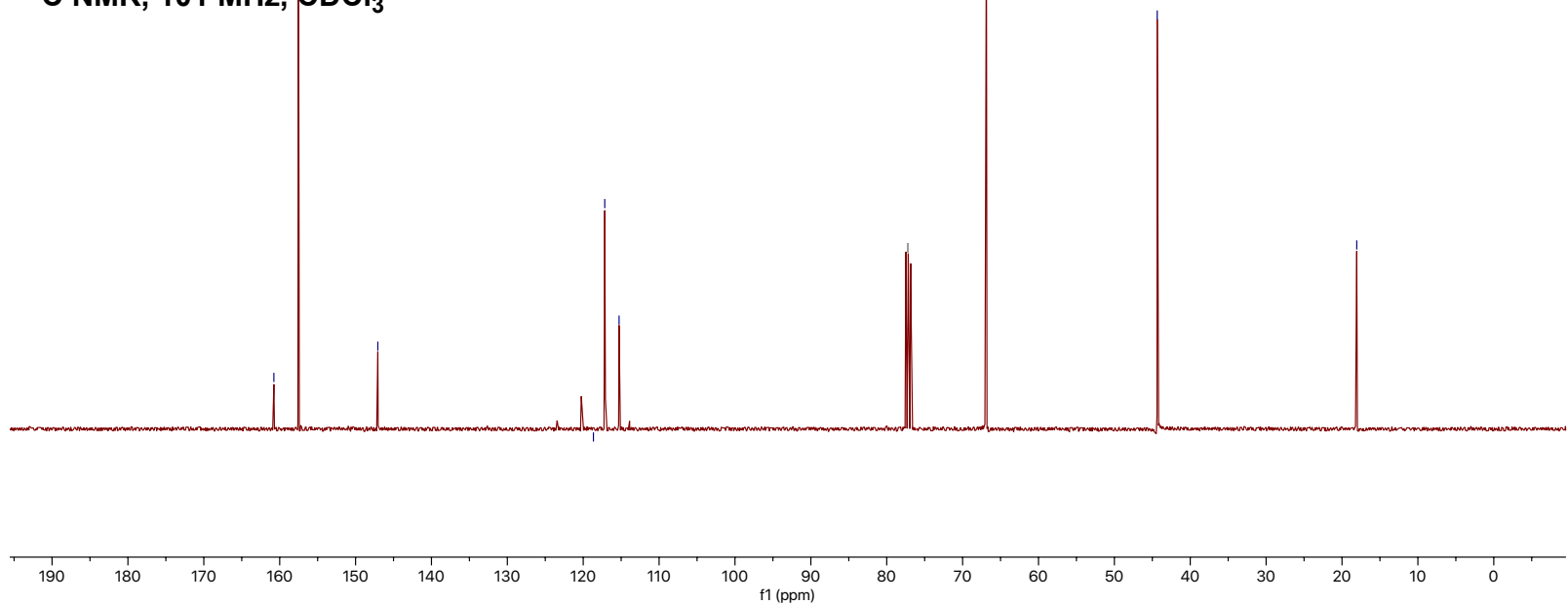
Supporting Information<smiles>C/C([O])=C\c1cnc(N2CCOCC2)nc1</smiles>

SI-2t

${ }^{19}$ F NMR, $471 \mathrm{MHz} . \mathrm{CDCl}_{3}$ $\infty$

$\stackrel{n}{n}$

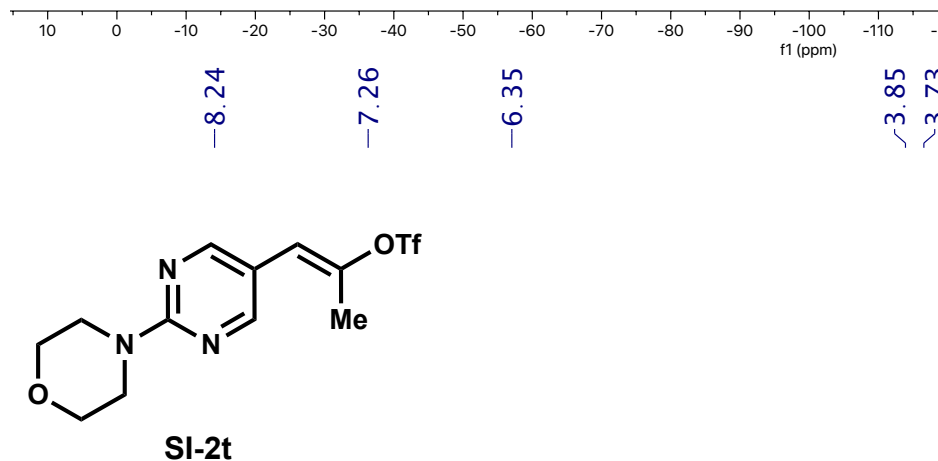

SI-2t

1D NOE, $400 \mathrm{MHz}, \mathrm{CDCl}_{3}$
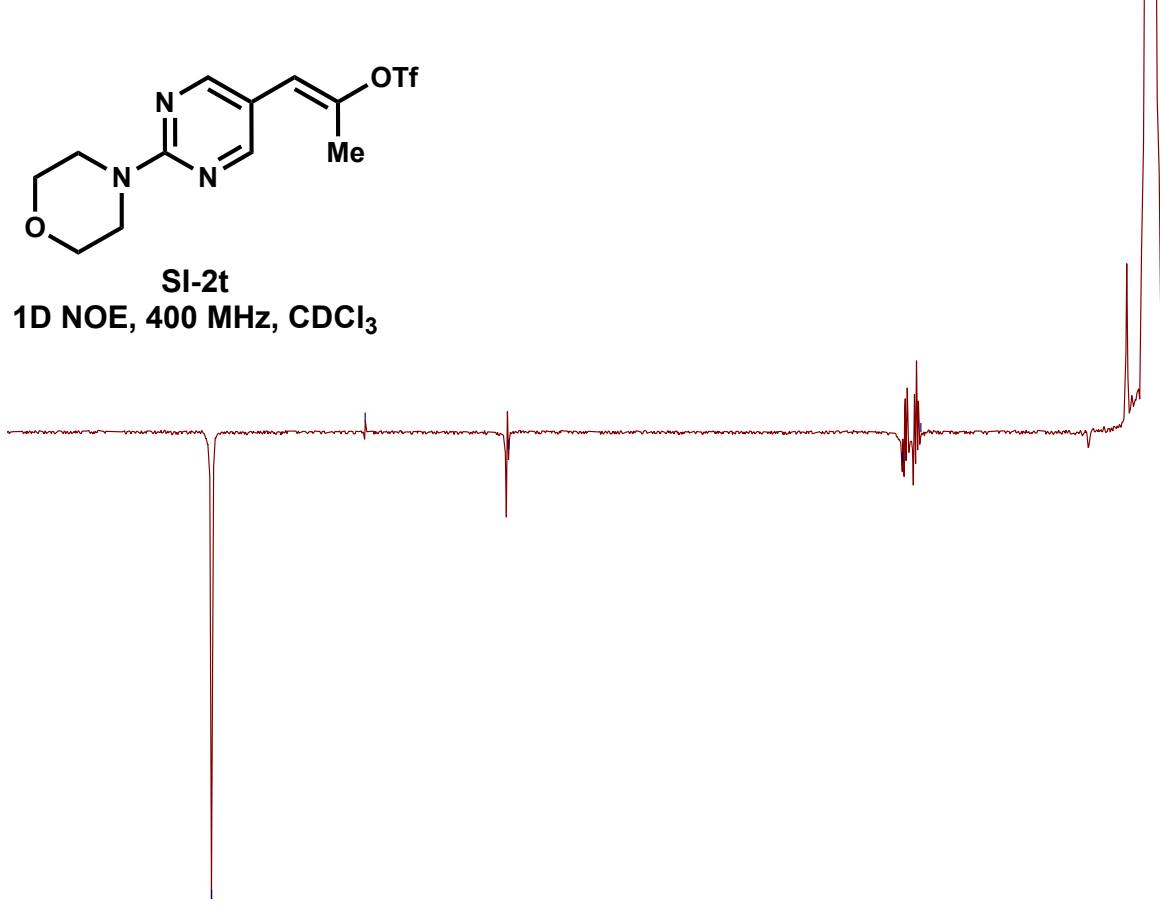

$\begin{array}{llllllll}8.0 & 7.5 & 7.0 & 6.5 & 6.0 & 5.5 & 5.0 & 4.5 \\ \mathrm{f} 1(\mathrm{ppm})\end{array}$

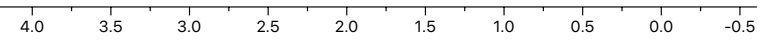


Supporting Information

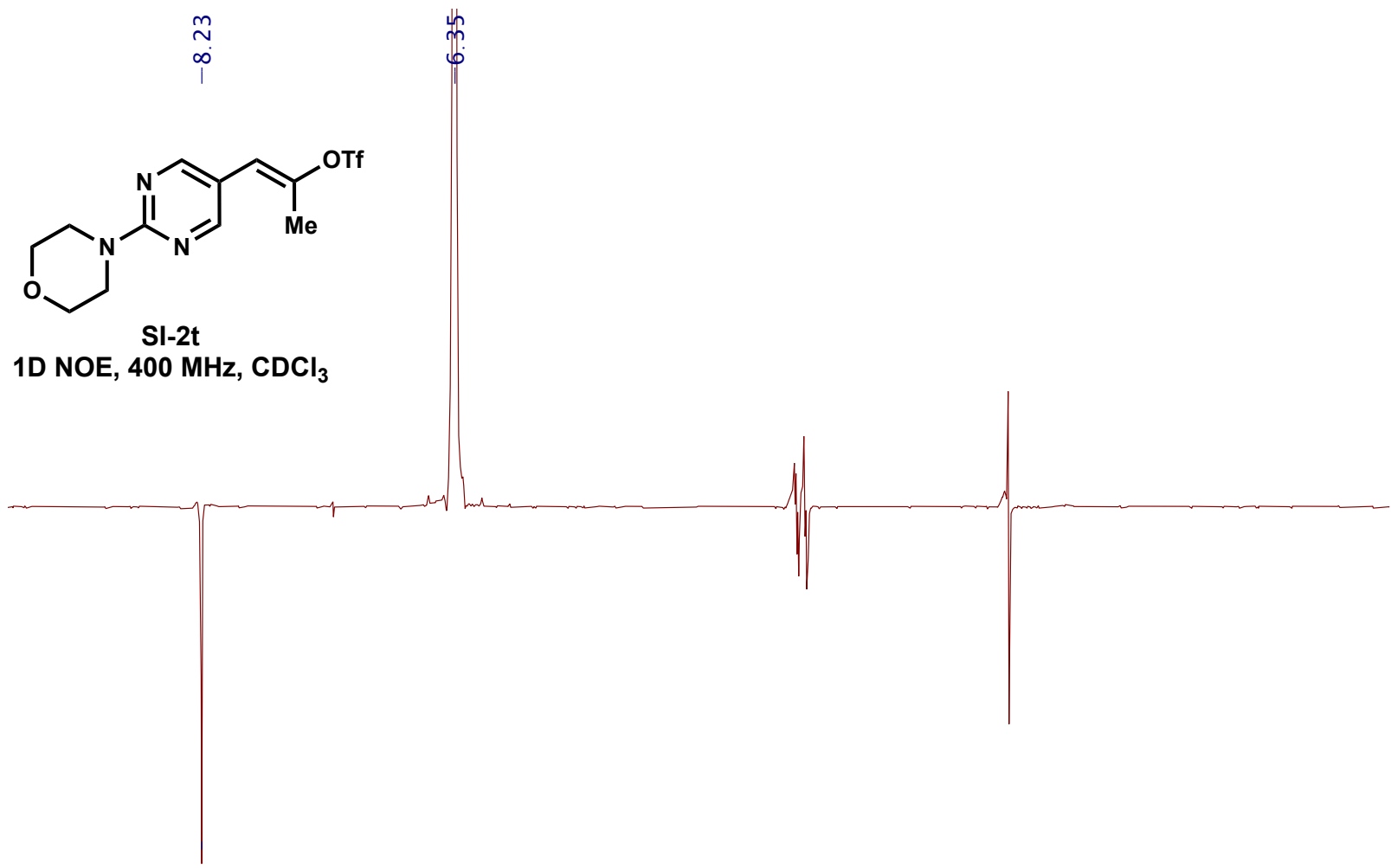

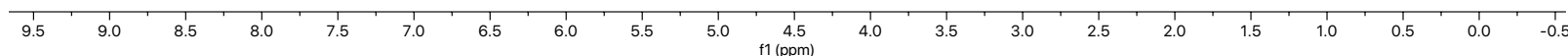


Supporting Information
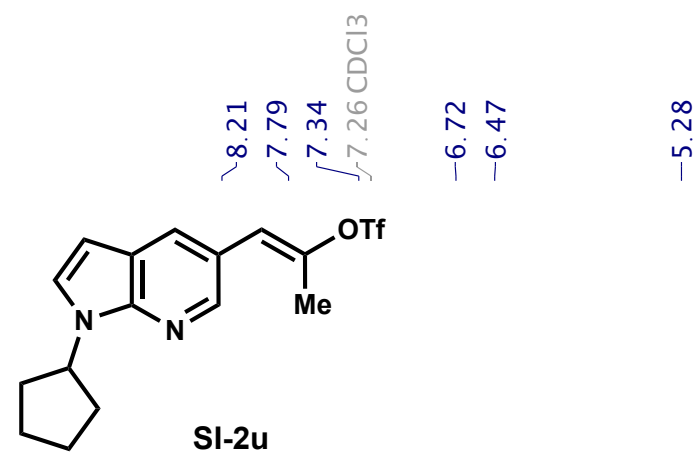

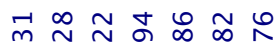

ำ

${ }^{1} \mathrm{H}$ NMR, $400 \mathrm{MHz}^{\mathrm{CDCl}_{3}}$

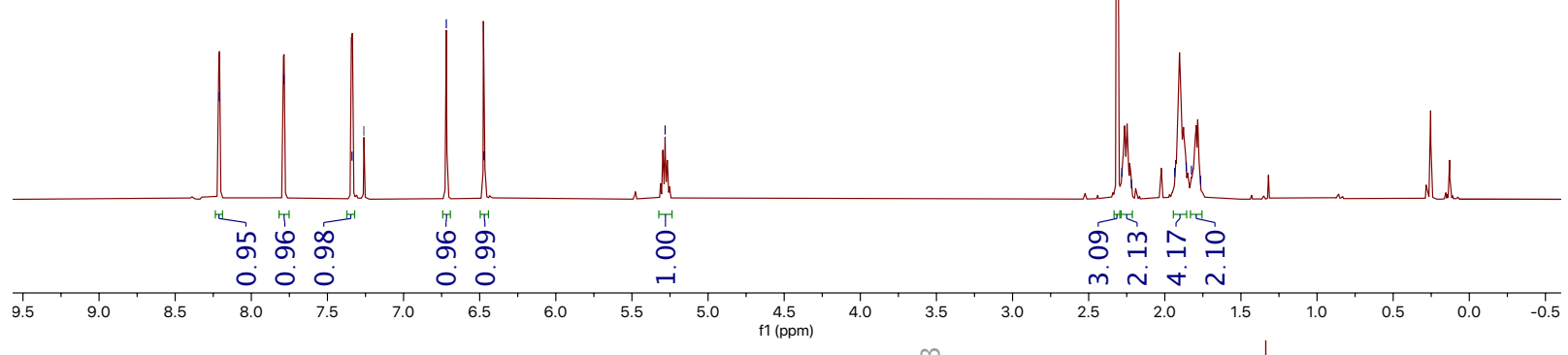

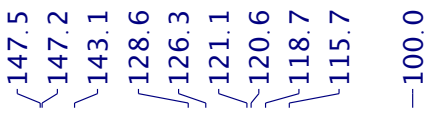

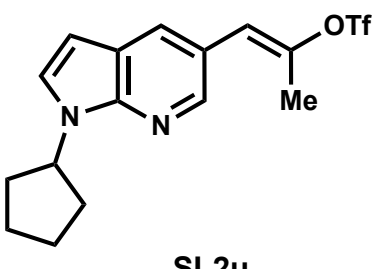

${ }^{13} \mathrm{C}$ NMR, $101 \mathrm{MHz}, \mathrm{CDCl}_{3}$
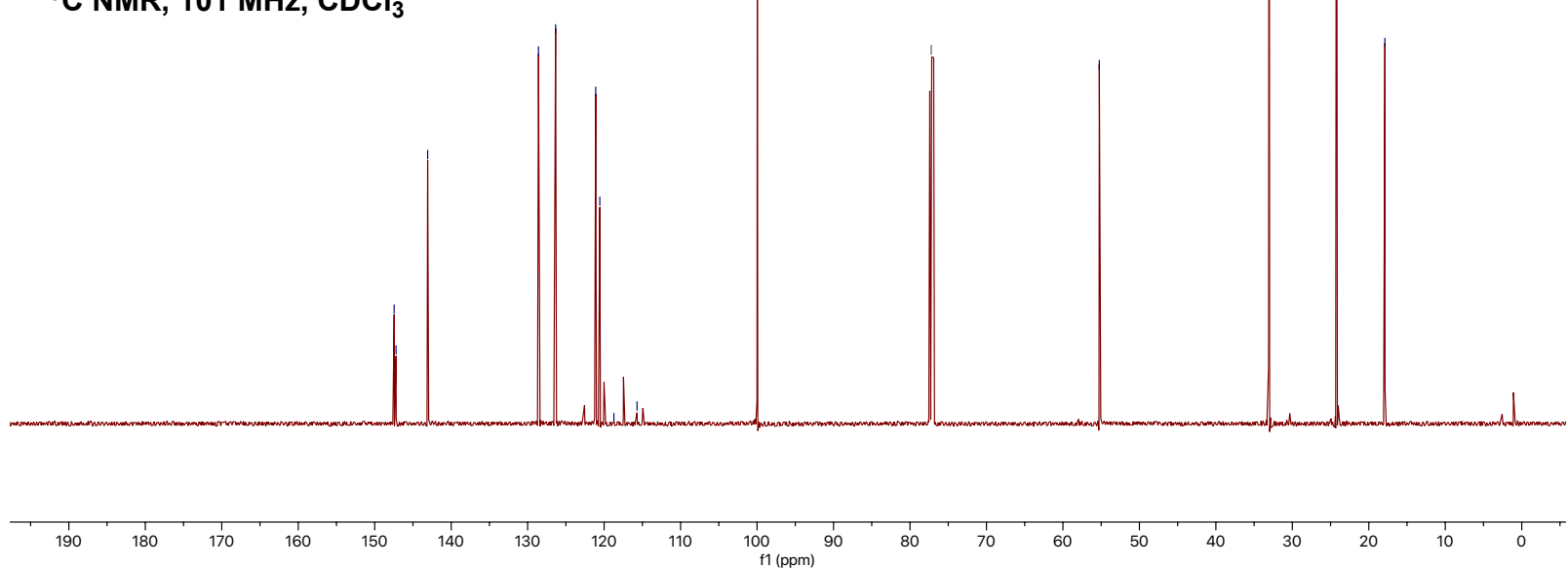
Supporting Information

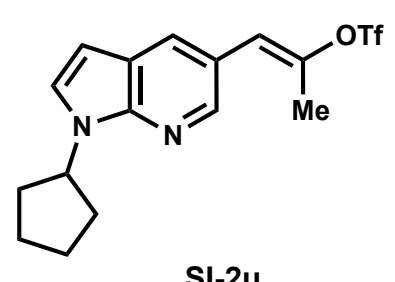

$\infty$
$n$

1

${ }^{19} \mathrm{~F}$ NMR, $471 \mathrm{MHz}, \mathrm{CDCl}_{3}$

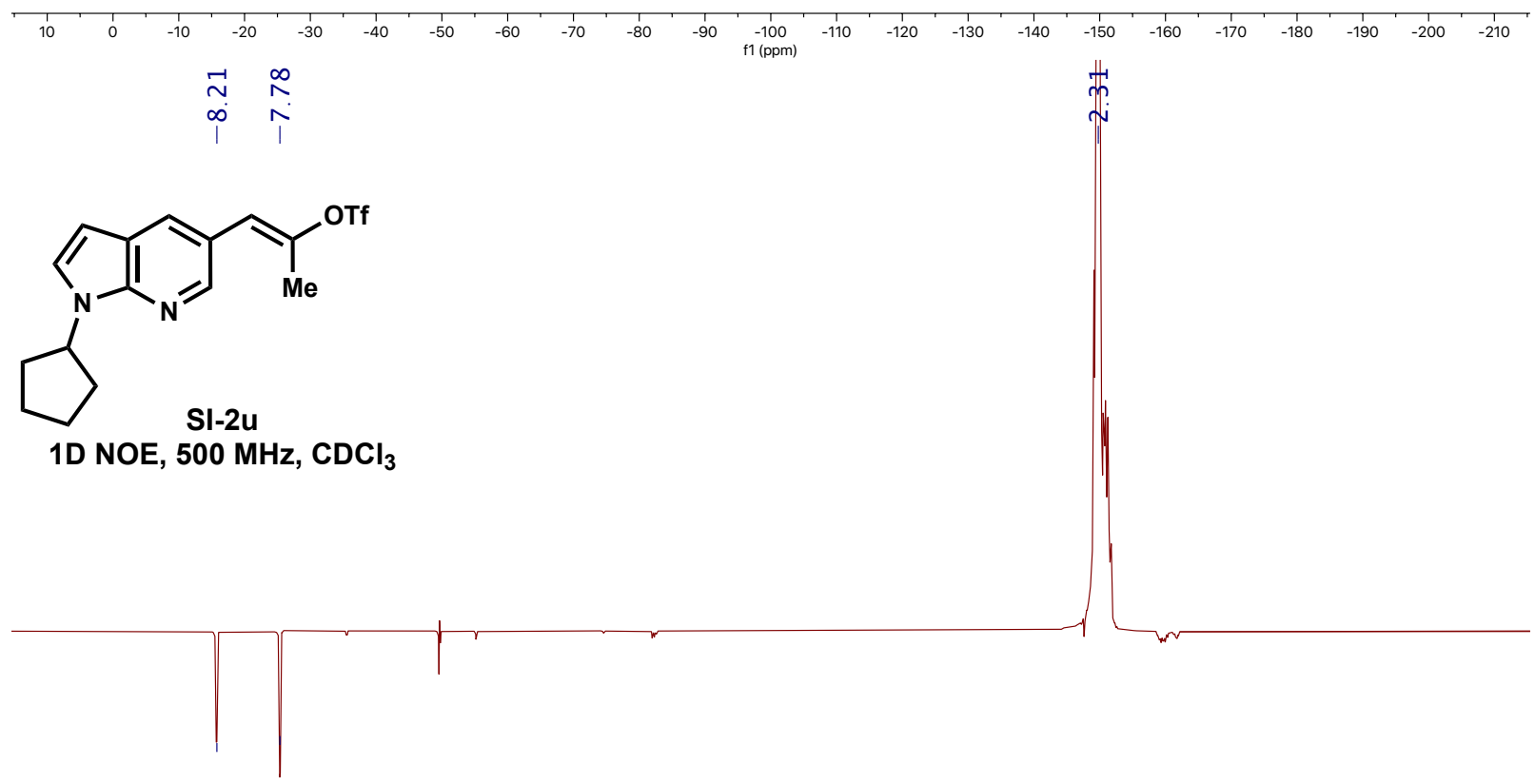

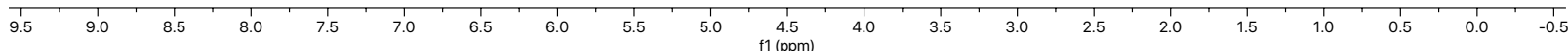


Supporting Information
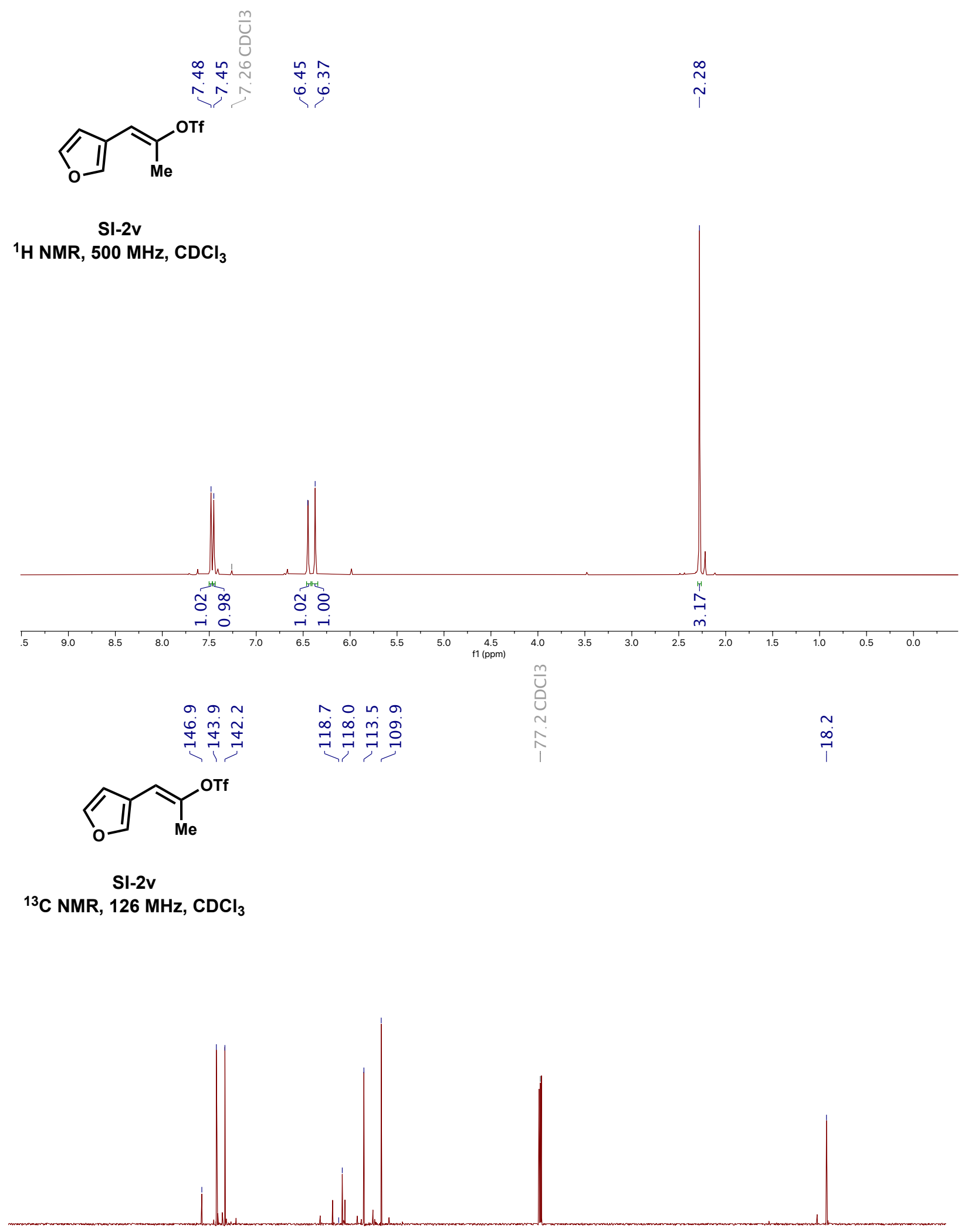
Supporting Information
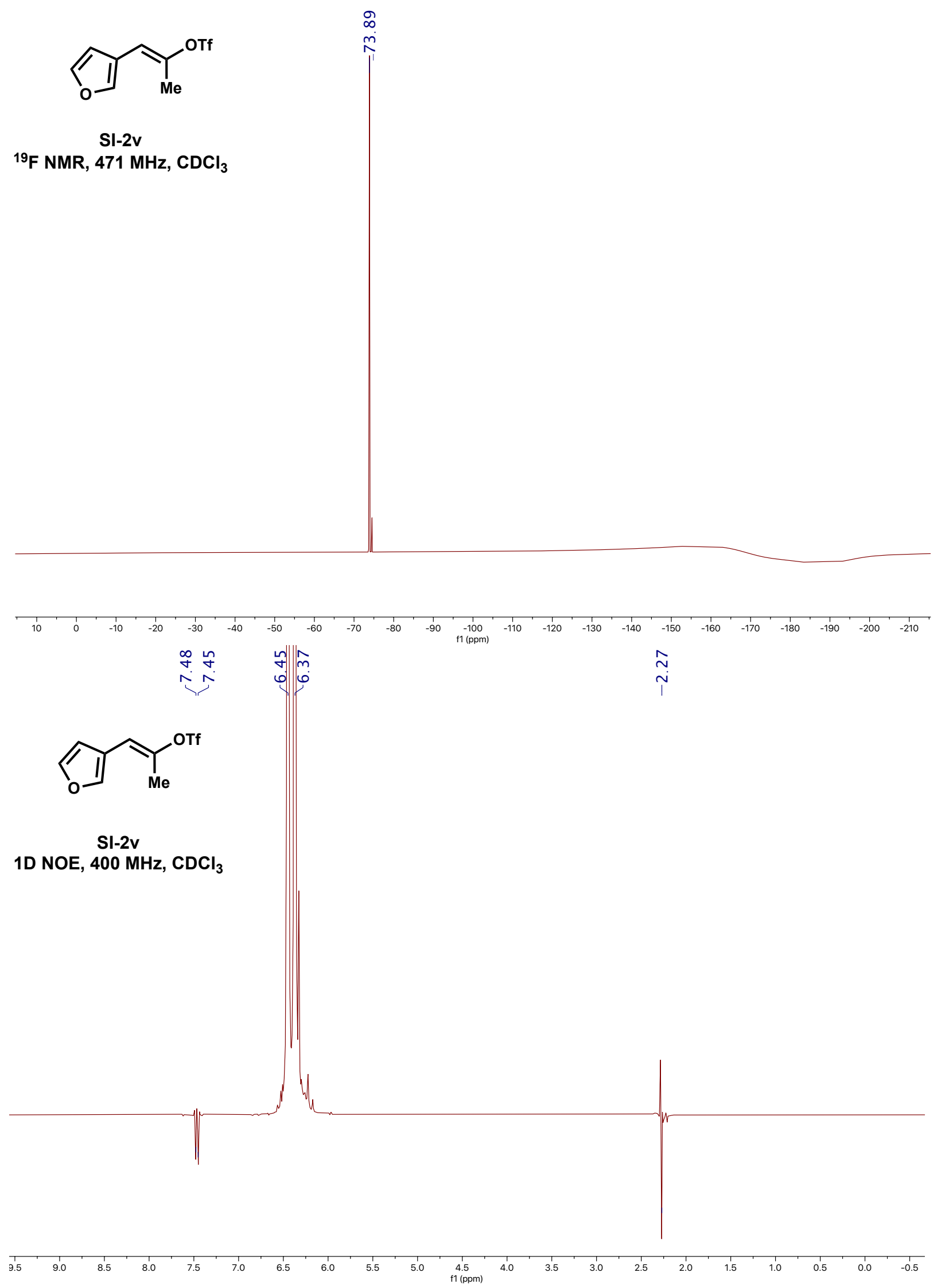
Supporting Information

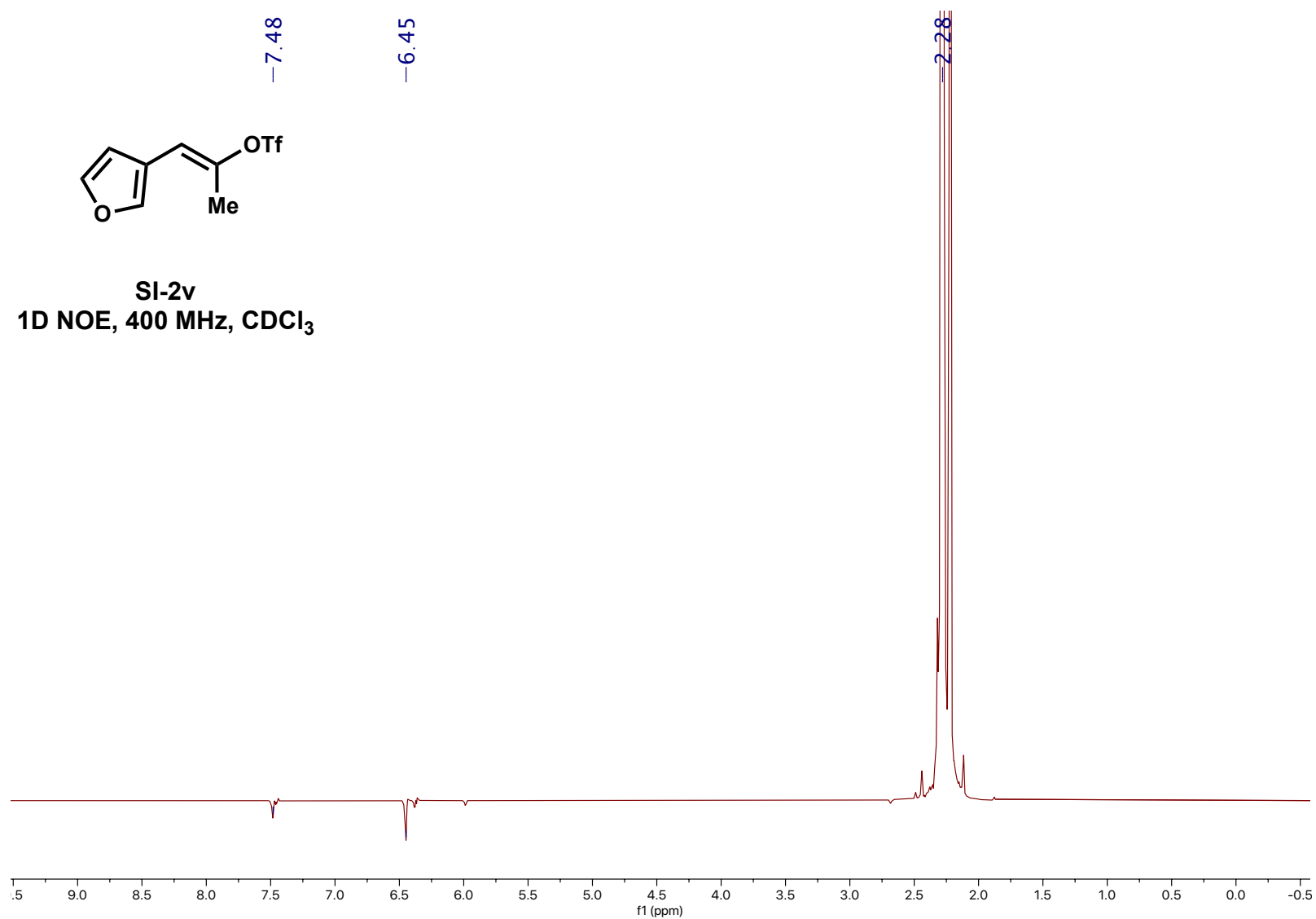


Supporting Information

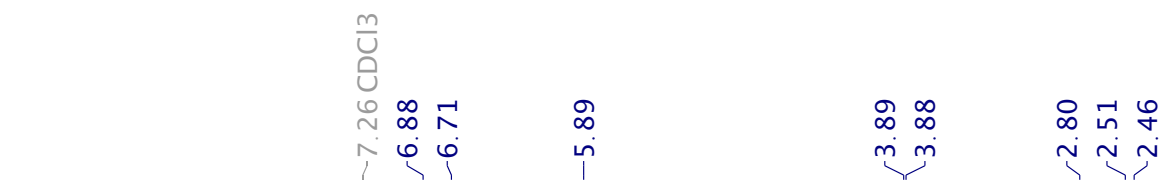<smiles>O=[N+]([O-])Oc1cc2c(cc1[O-])CCC=C2Br</smiles>

SI-2w

${ }^{1} \mathrm{H}$ NMR, $400 \mathrm{MHz}, \mathrm{CDCl}_{3}$

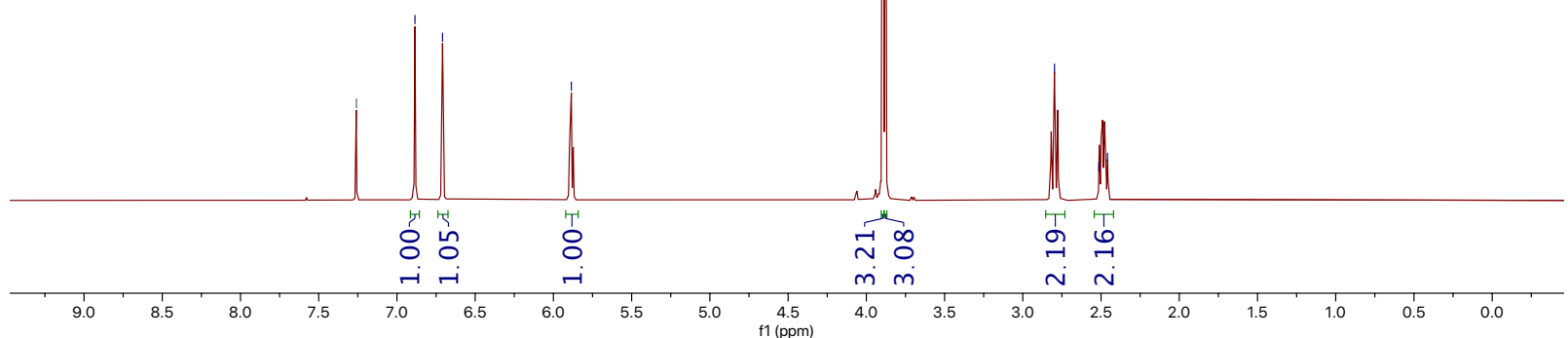<smiles>CCCC1=CCCc2cc(OC)c(OC)cc21</smiles>

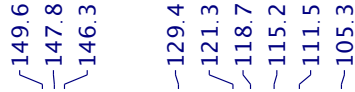

诲

$\infty N$

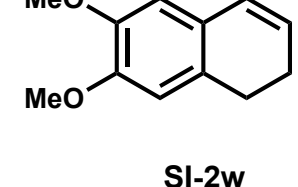

${ }^{13} \mathrm{C}$ NMR, $101 \mathrm{MHz}, \mathrm{CDCl}_{3}$

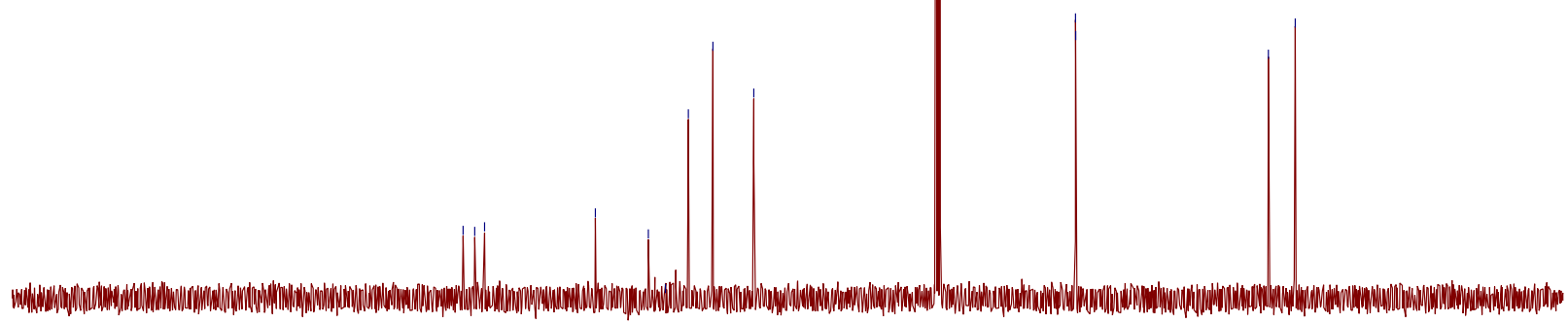


Supporting Information

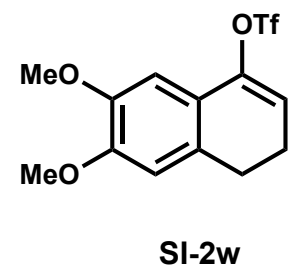

$\stackrel{n}{\wedge}$

$\stackrel{n}{i}$

${ }^{19} \mathrm{~F} \mathrm{NMR,} 376 \mathrm{MHz}^{\mathrm{CDCl}} 3$

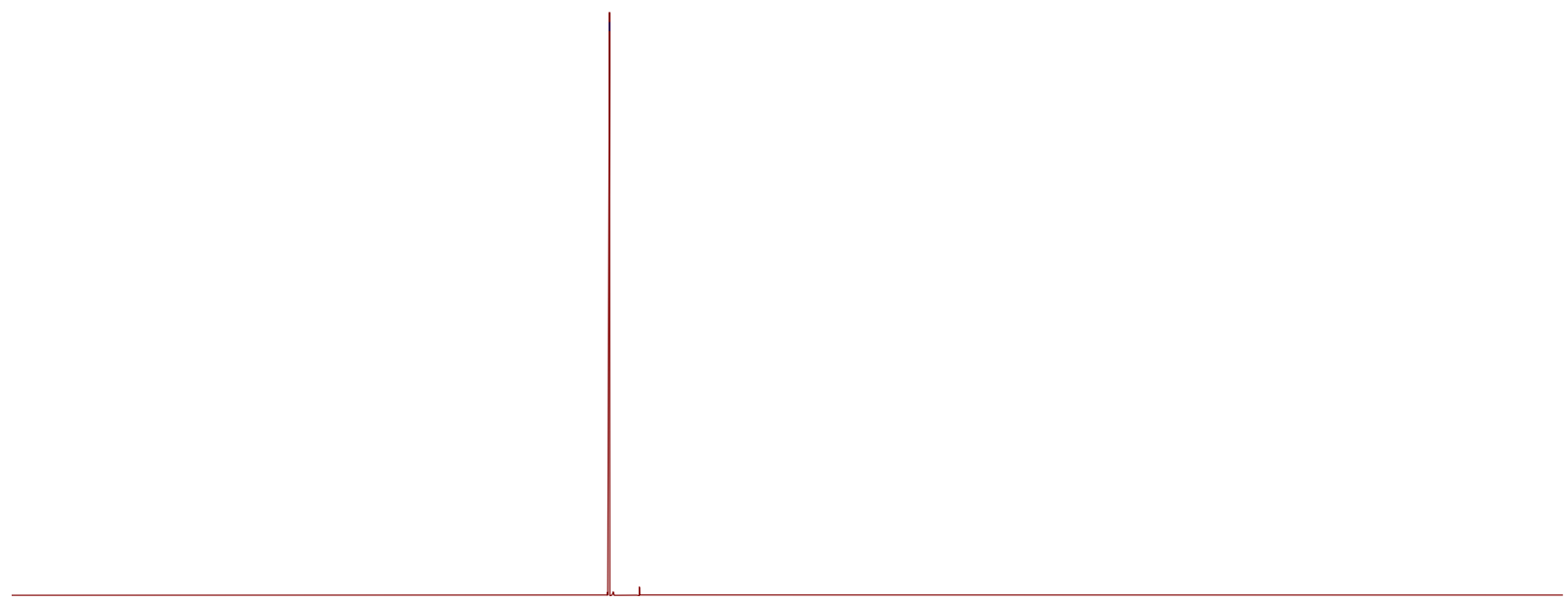

\begin{tabular}{lllllllllllllllllllllll}
\hline 10 & 0 & -10 & -20 & -30 & -40 & -50 & -60 & -70 & -80 & -90 & -100 & -110 & -120 & -130 & -140 & -150 & -160 & -170 & -180 & -190 & -200 & -210
\end{tabular} 
Supporting Information

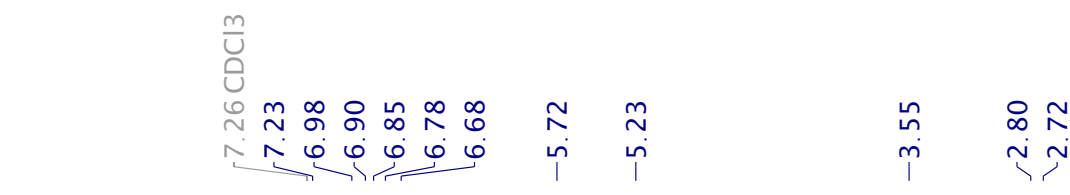

$\underbrace{2}$

SI-5j

${ }^{1} \mathrm{H}$ NMR, $500 \mathrm{MHz}^{\mathrm{CDCl}}{ }_{3}$

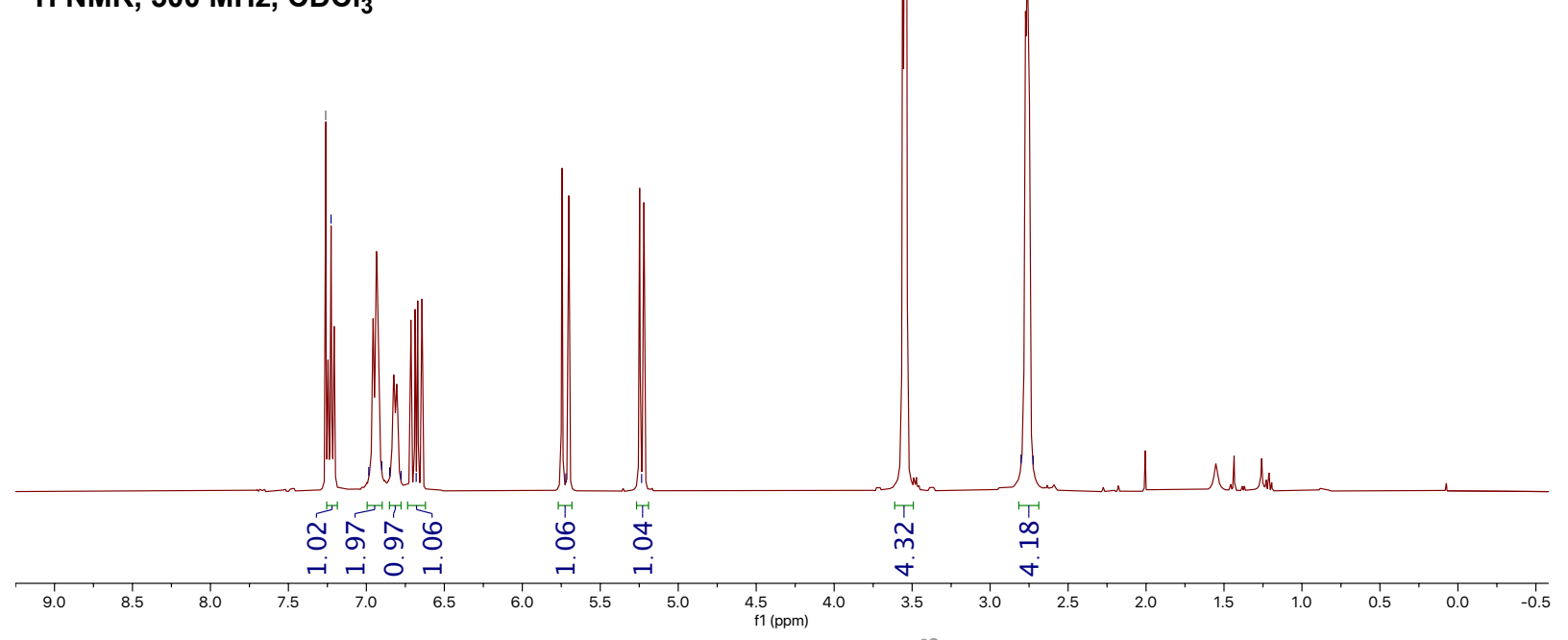<smiles>C=Cc1cccc(N2CCSCC2)c1</smiles>

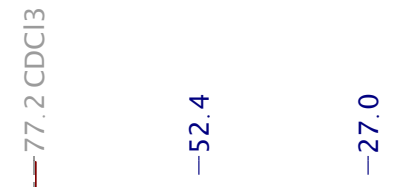

SI-5j

${ }^{13} \mathrm{C}$ NMR, $126 \mathrm{MHz}, \mathrm{CDCl}_{3}$

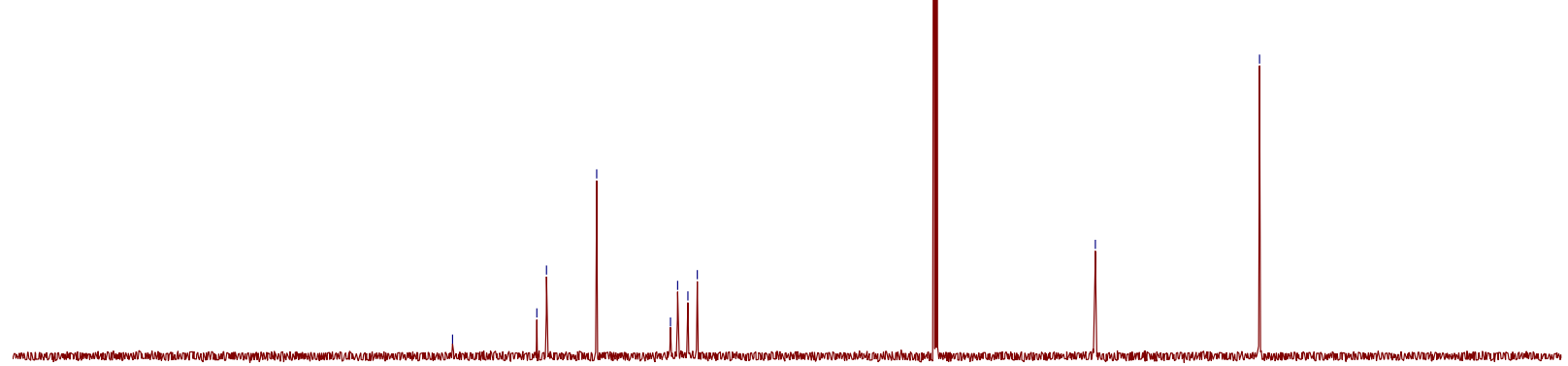


Supporting Information
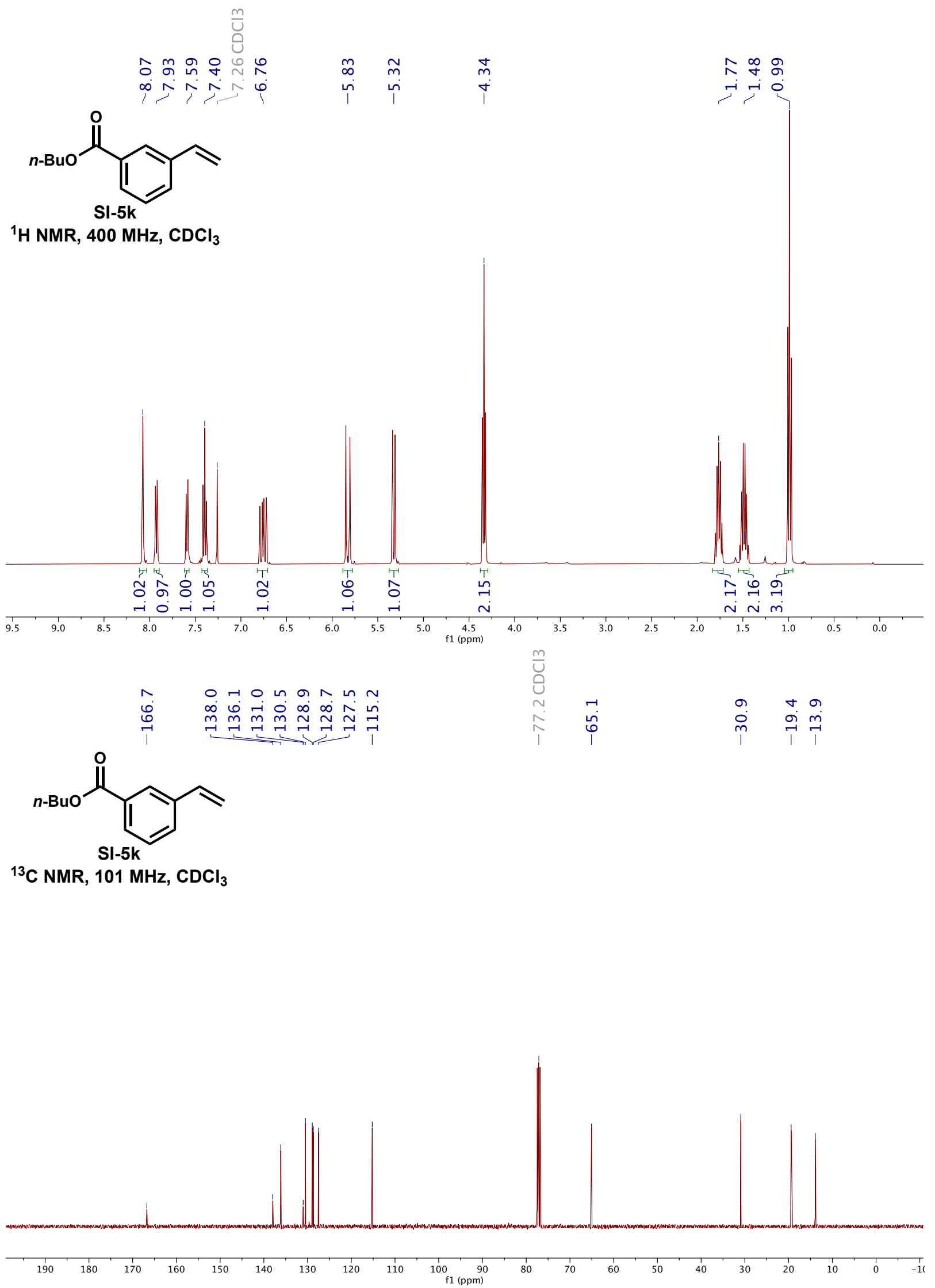
Supporting Information

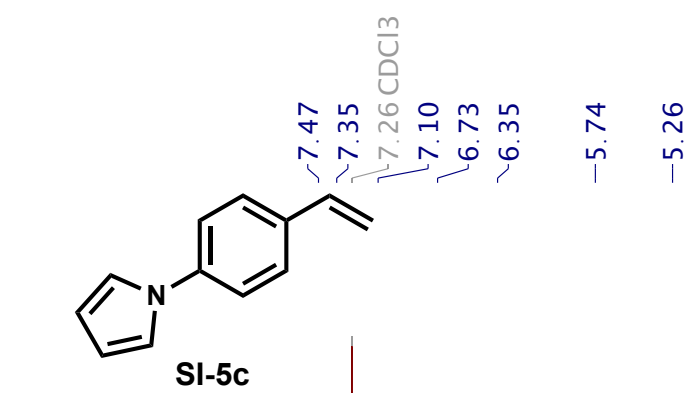

${ }^{1} \mathrm{H}$ NMR, $400 \mathrm{MHz}, \mathrm{CDCl}_{3}$

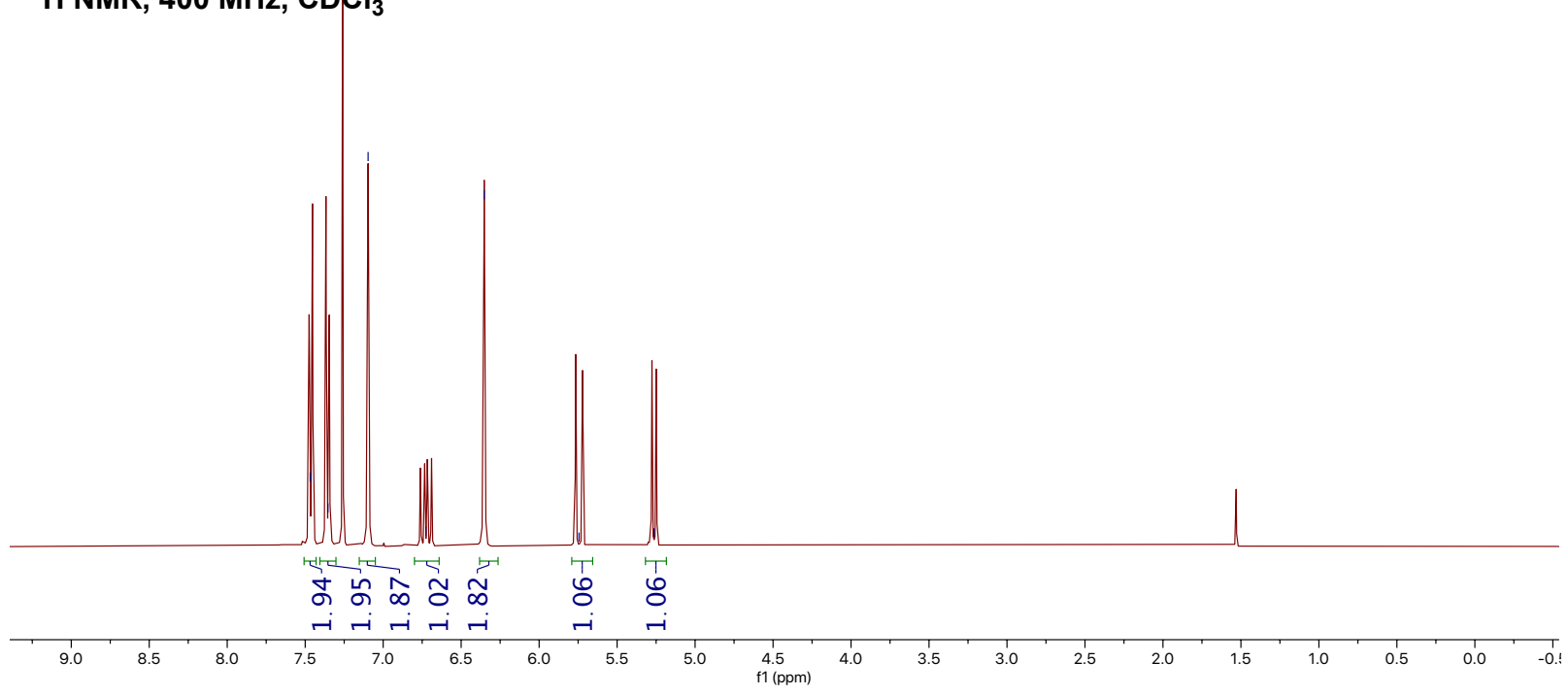

$m \circ \sim$ n n $m a b$

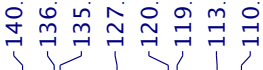

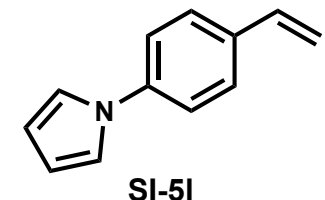

${ }^{13} \mathrm{C}$ NMR, $101 \mathrm{MHz}, \mathrm{CDCl}_{3}$

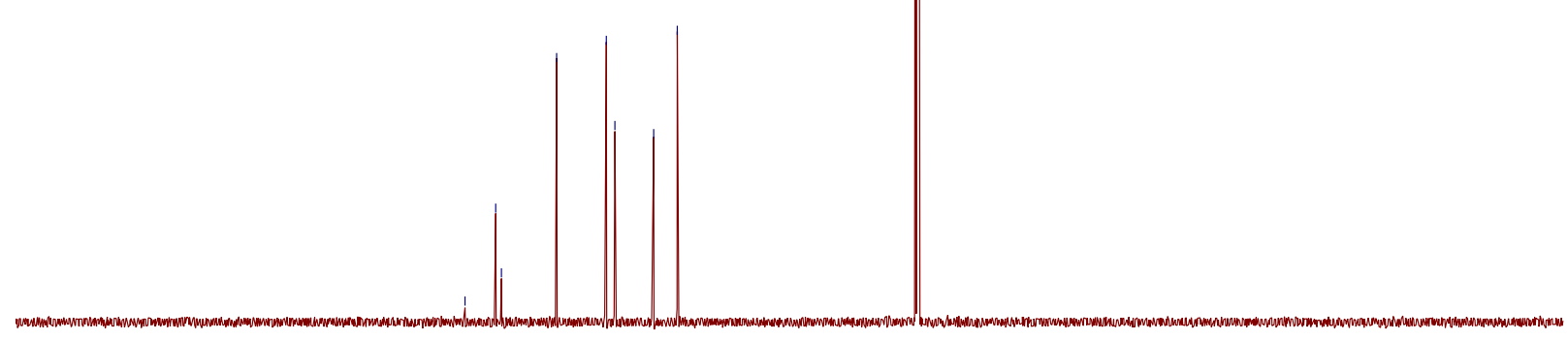

\begin{tabular}{lllllllllll}
\hline 200 & 190 & 180 & 170 & 160 & 150 & 140 & 130 & 120 & 110 & $\left.1000_{\mathrm{f} 1(\mathrm{ppm})}^{1}\right)^{1}$
\end{tabular} 
Supporting Information

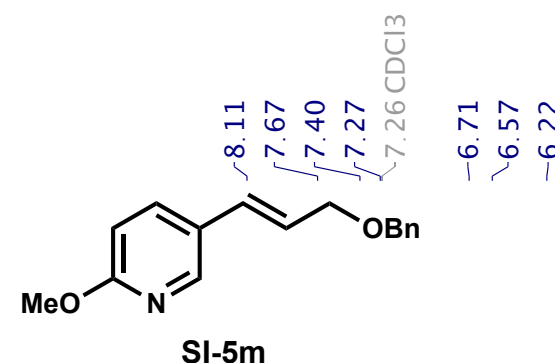

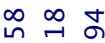

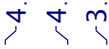

${ }^{1} \mathrm{H}$ NMR, $400 \mathrm{MHz}, \mathrm{CDCl}_{3}$
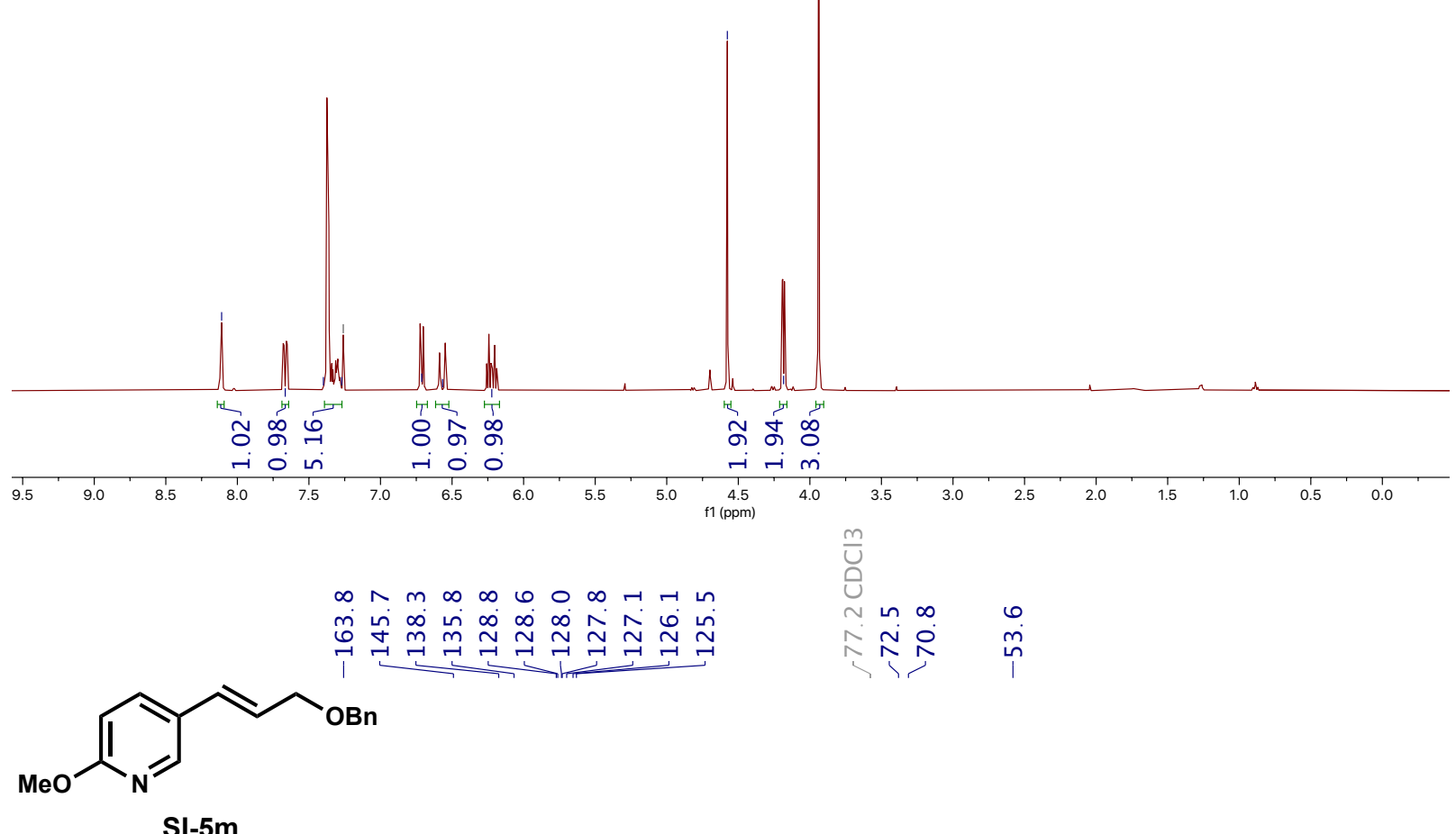

$\infty \wedge m \infty \infty \quad \omega \quad 0 \quad \infty-1-r$ in

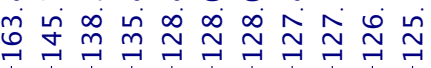

$\frac{m}{\cup}$

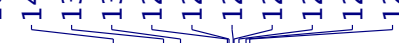

$\sim \ln \infty \quad 6$

Nก̃

${ }^{13} \mathrm{C}$ NMR, $101 \mathrm{MHz}, \mathrm{CDCl}_{3}$
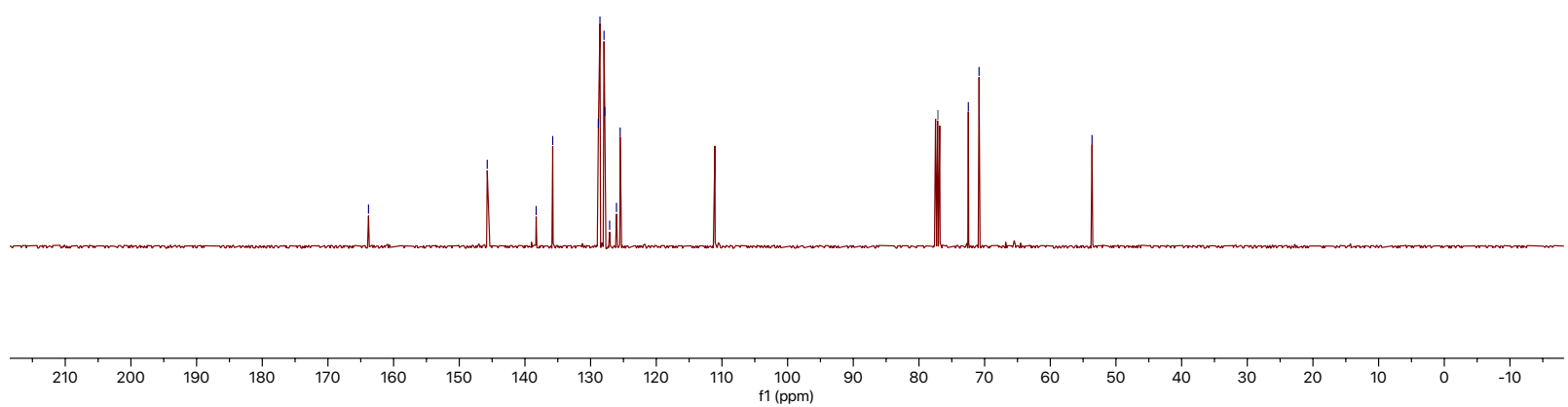
Supporting Information
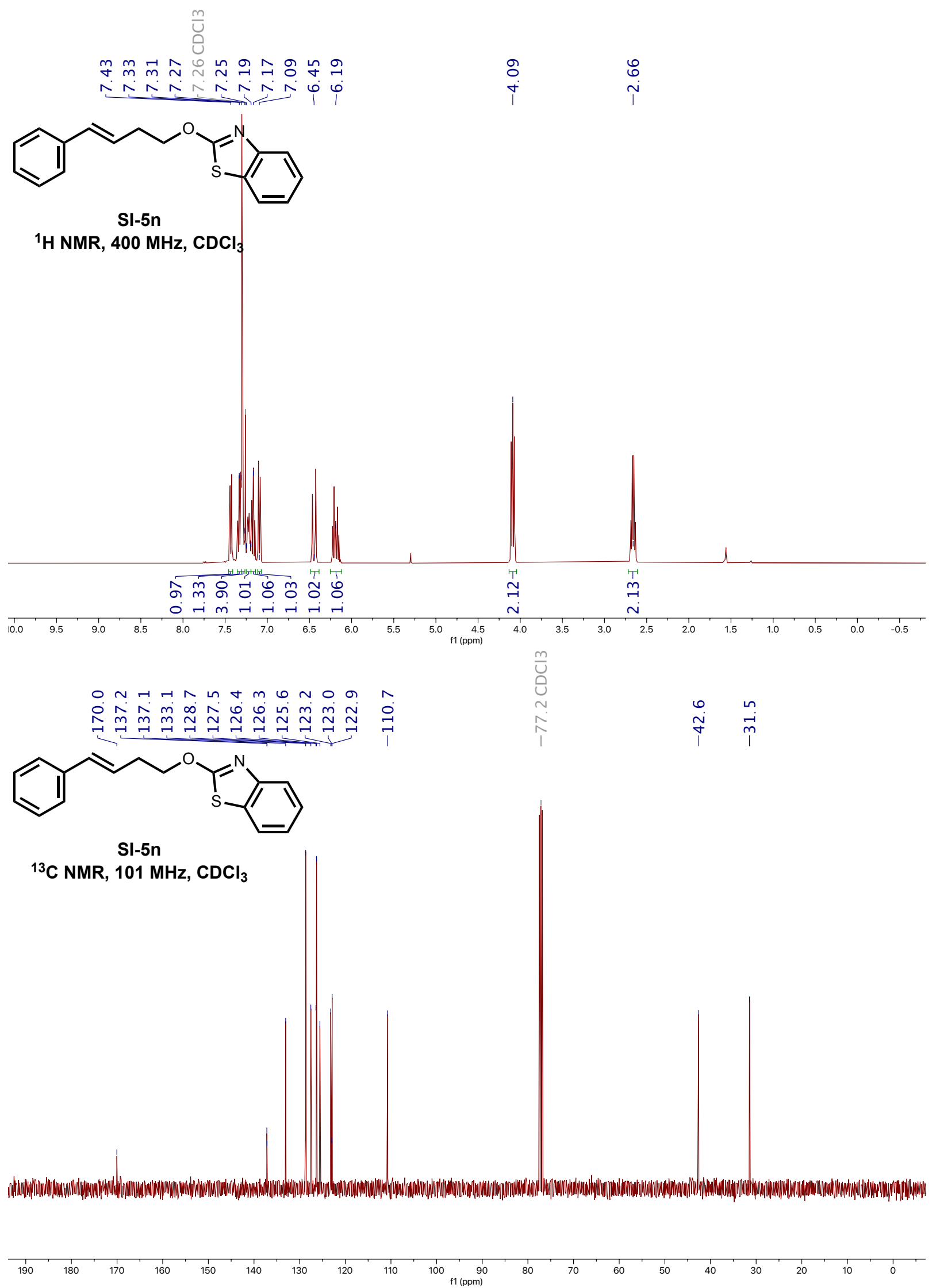
Supporting Information
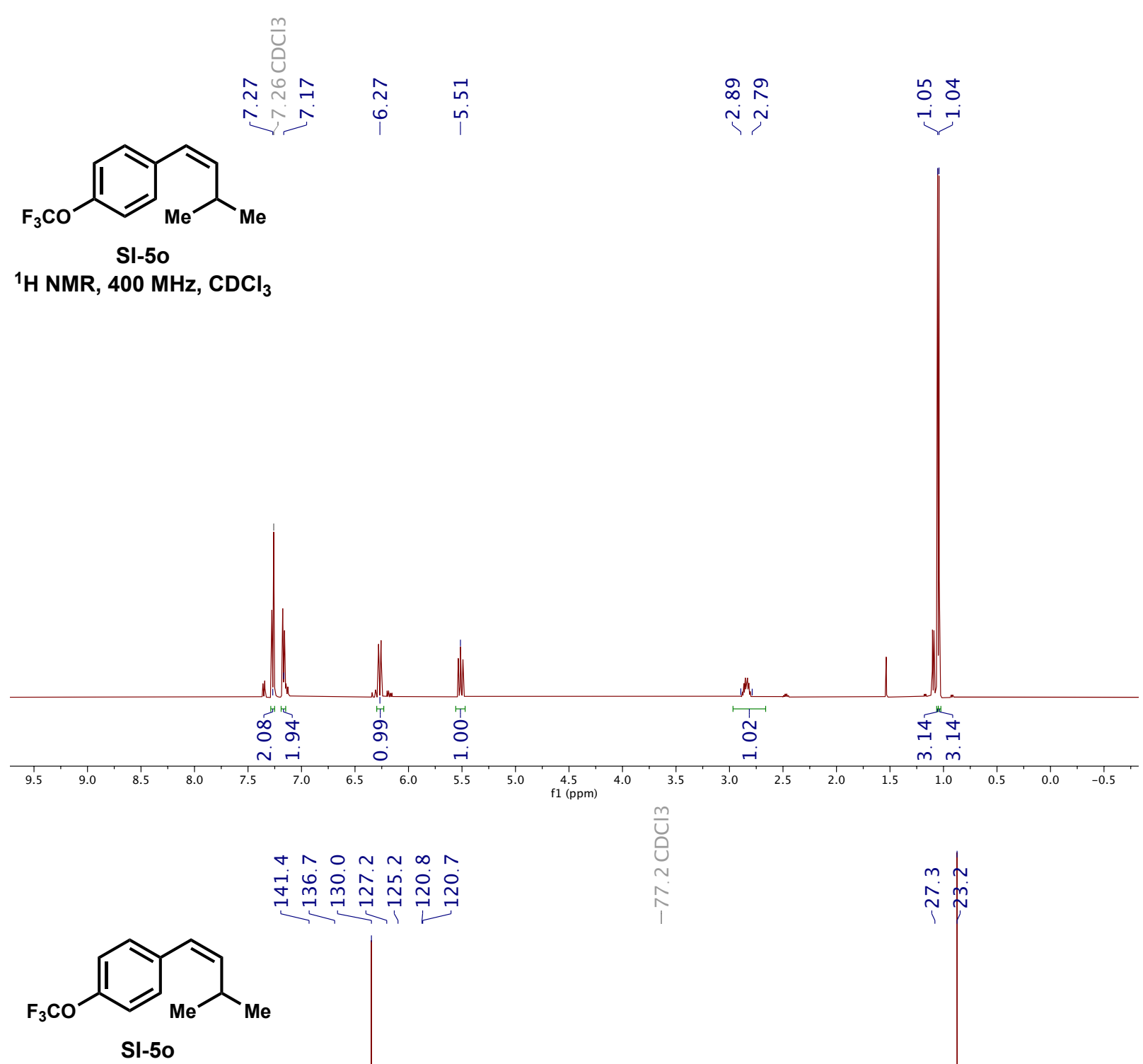

${ }^{13} \mathrm{C} \mathrm{NMR}, 126 \mathrm{MHz}, \mathrm{CDCl}_{3}$
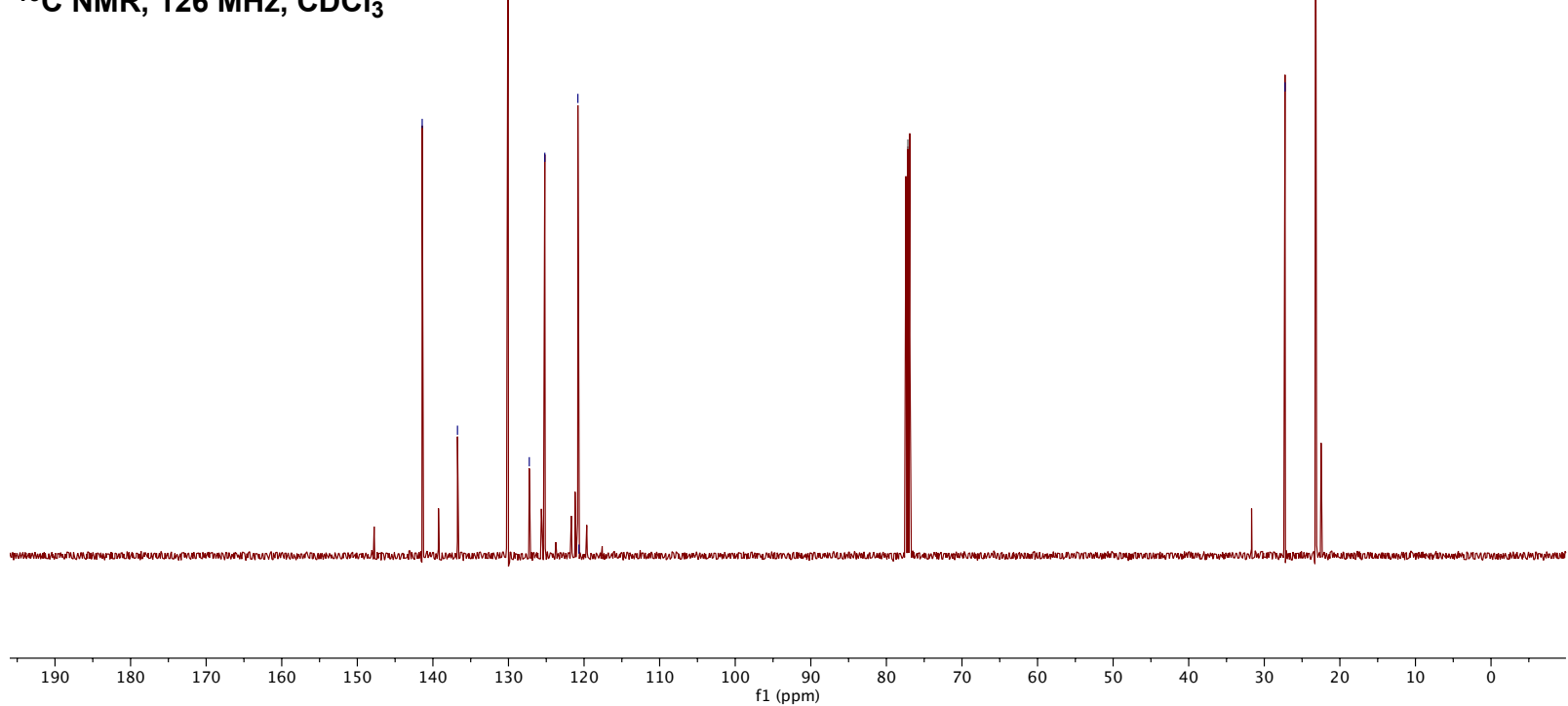
Supporting Information

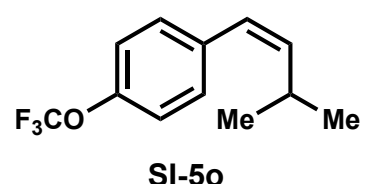

ก

${ }^{19} \mathrm{~F}$ NMR, $471 \mathrm{MHz}^{\mathrm{CDCl}_{3}}$

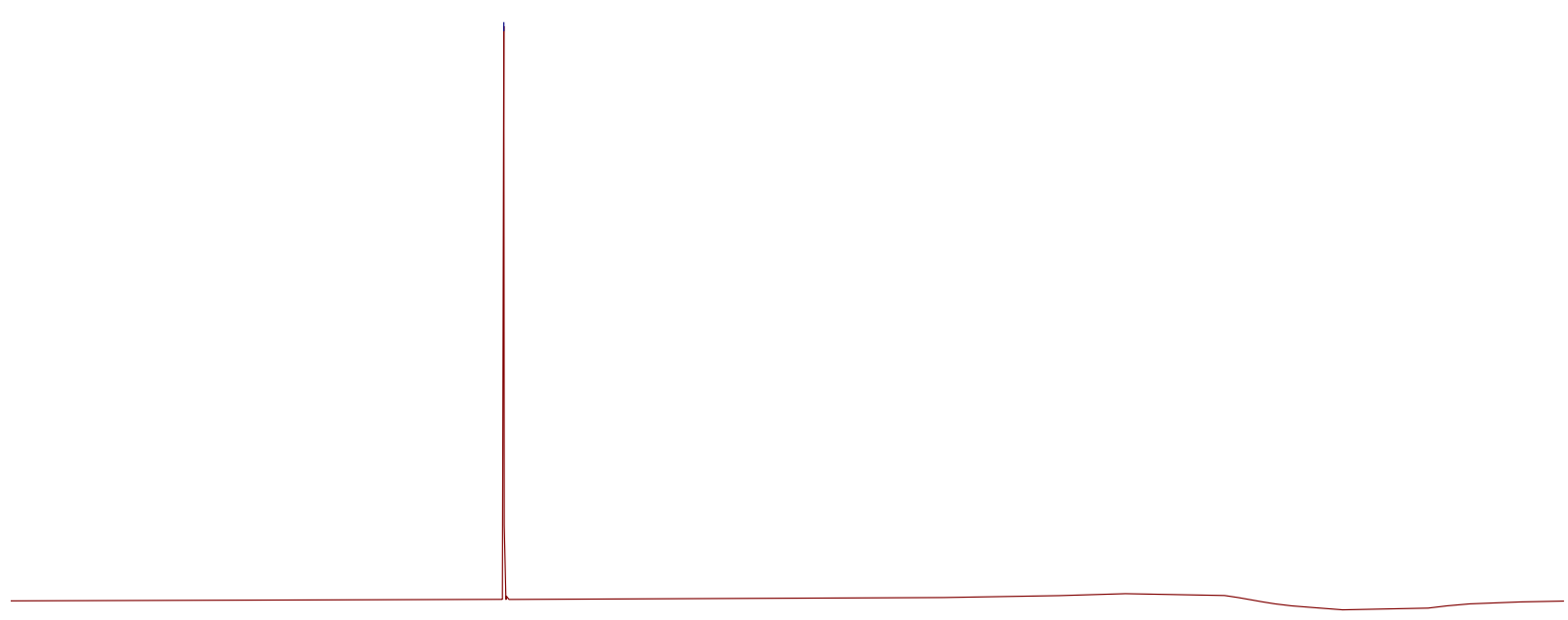

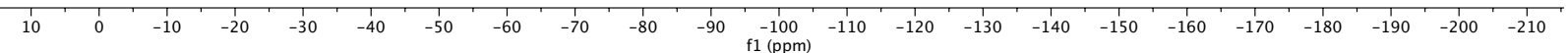


Supporting Information

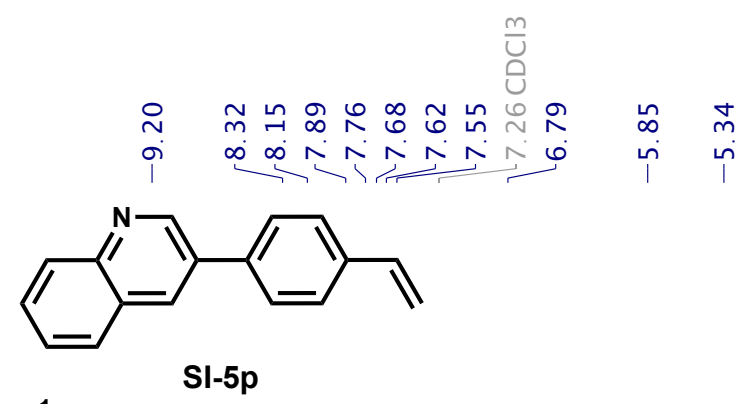

${ }^{1} \mathrm{H}$ NMR, $400 \mathrm{MHz}, \mathrm{CDCl}_{3}$

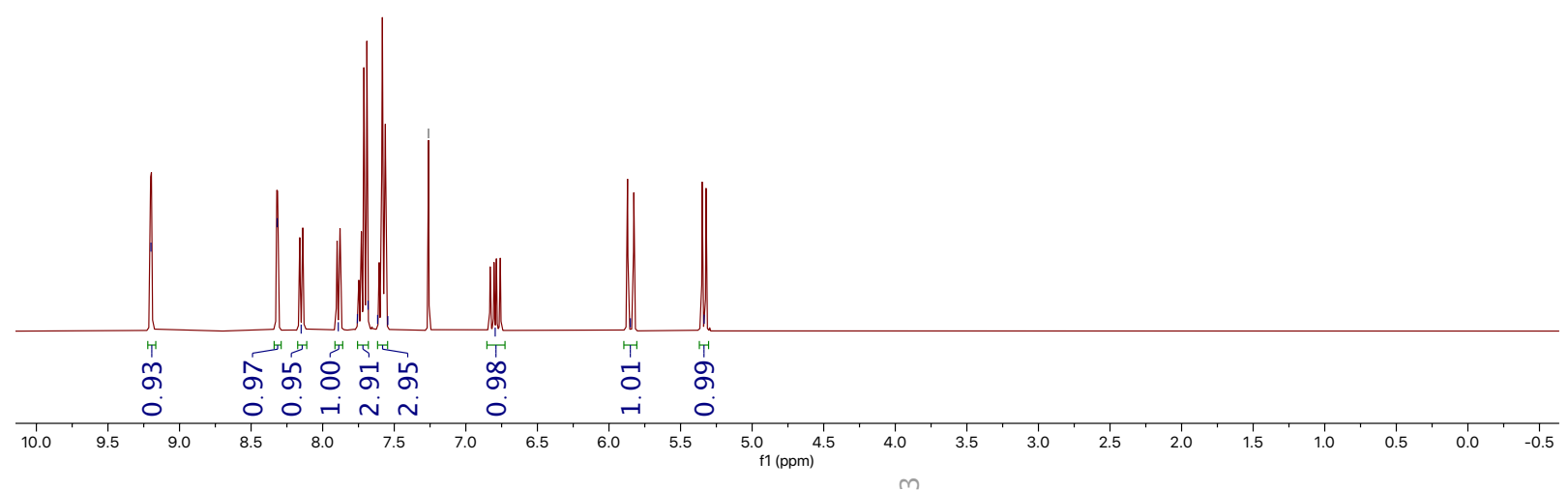

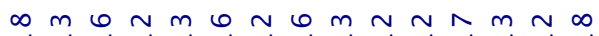

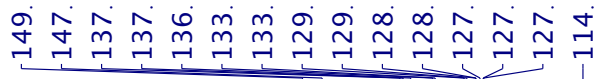

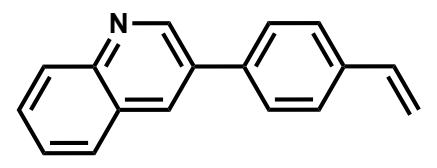

SI-5p

${ }^{13} \mathrm{C}$ NMR, $101 \mathrm{MHz}, \mathrm{CDCl}_{3}$
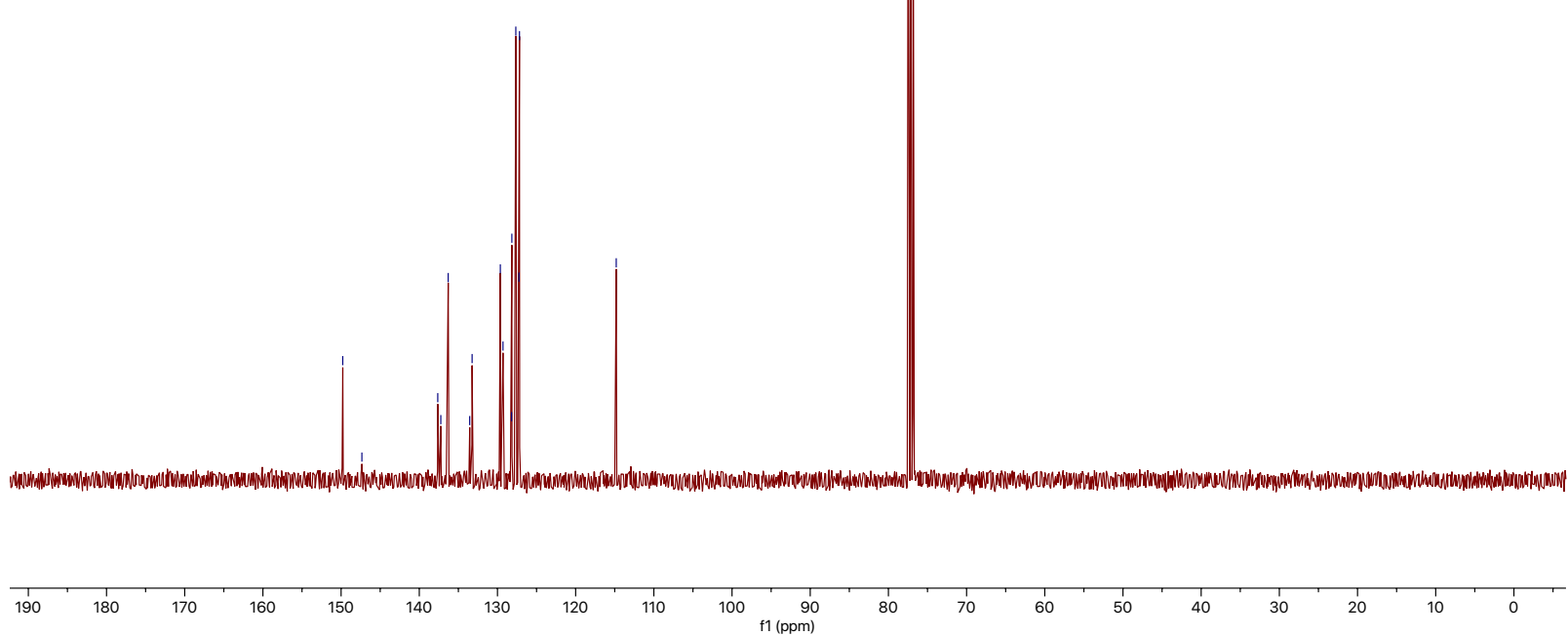
Supporting Information
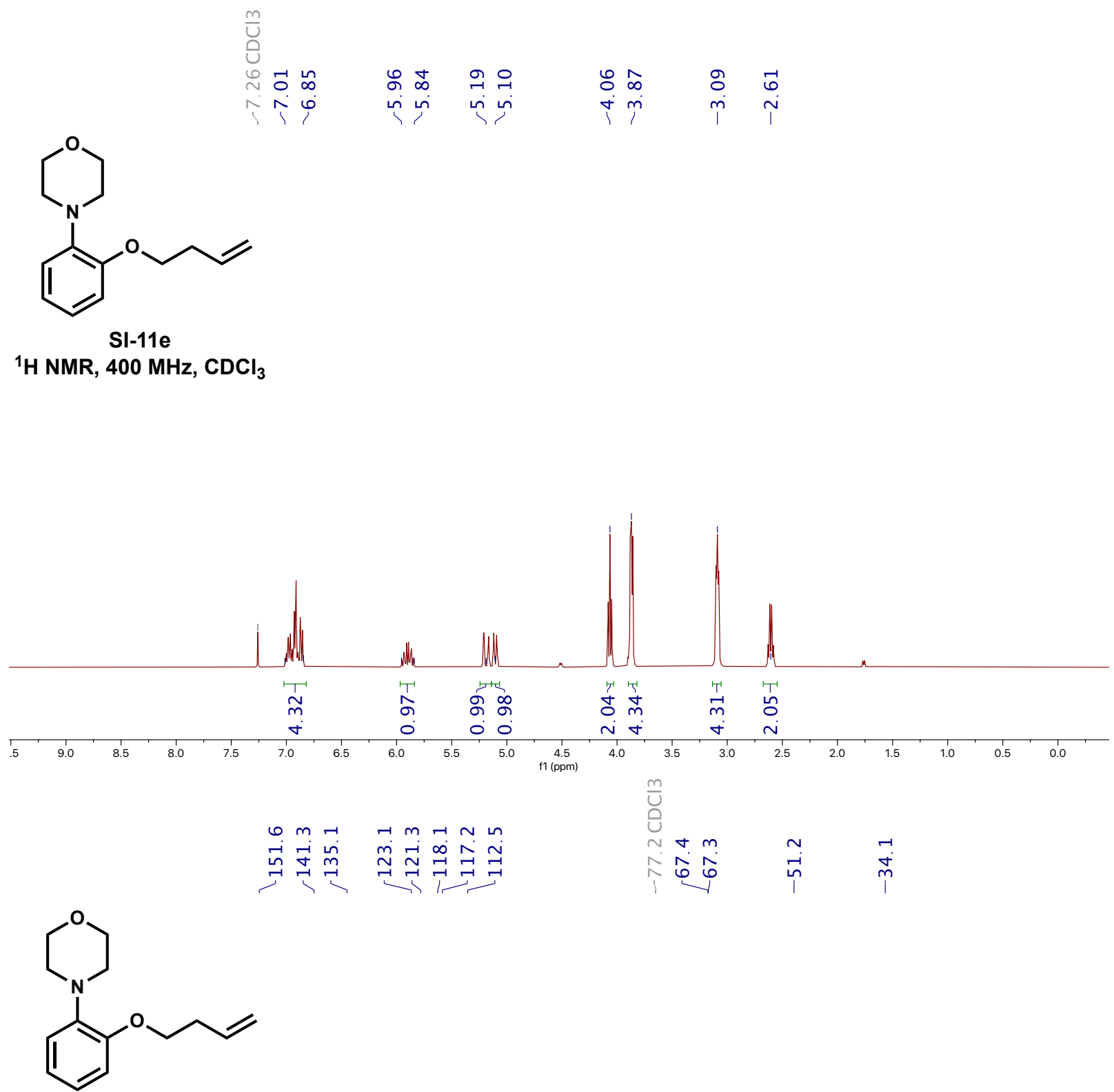

SI-11e

${ }^{13} \mathrm{C}$ NMR, $101 \mathrm{MHz}, \mathrm{CDCl}_{3}$
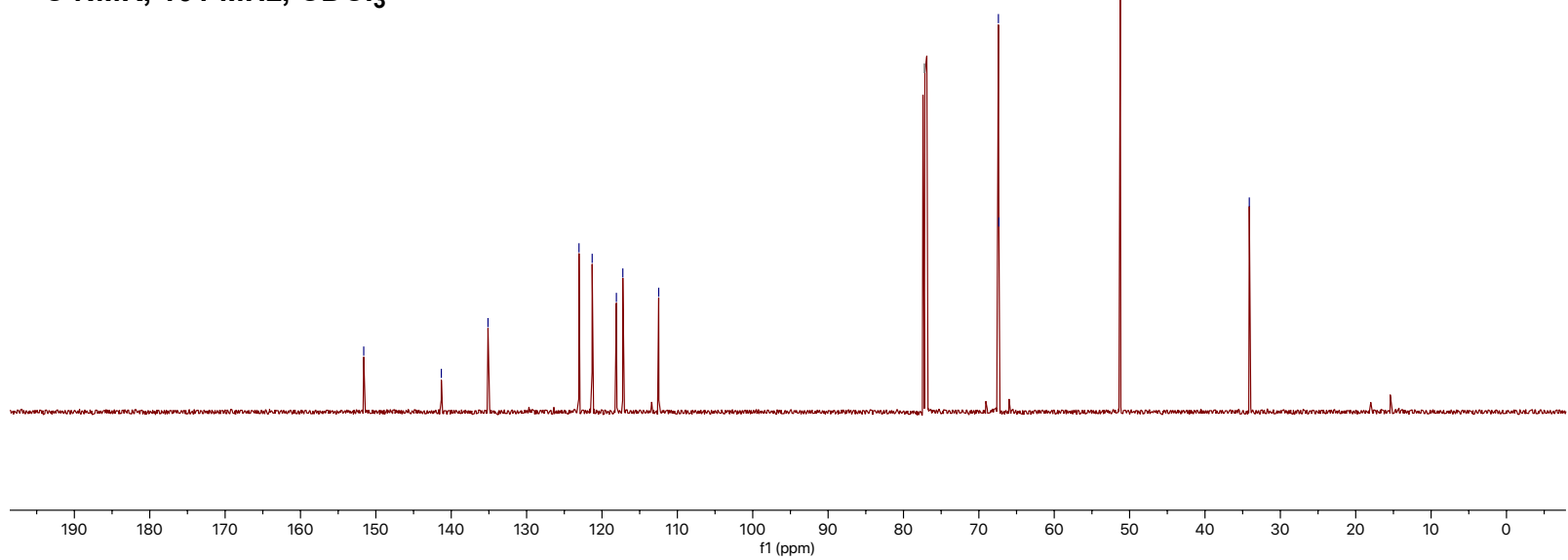
Supporting Information

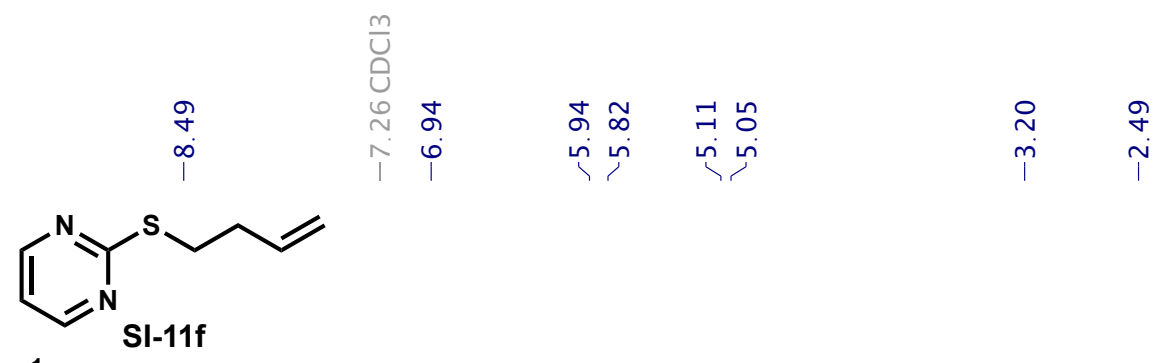

${ }^{1} \mathrm{H}$ NMR, $400 \mathrm{MHz}$, $\mathrm{CDCl}_{3}$

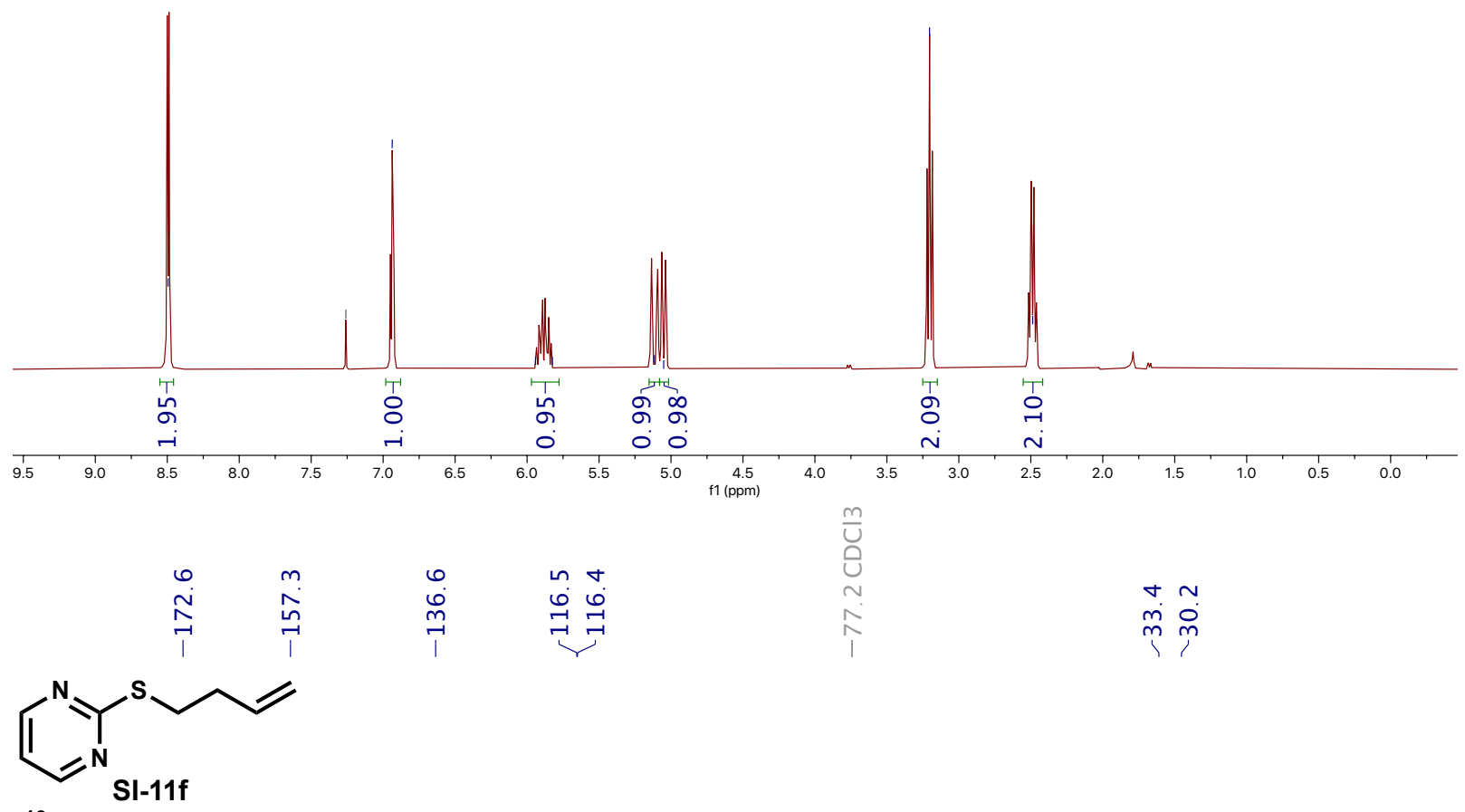

${ }^{13} \mathrm{C}$ NMR, $101 \mathrm{MHz}$, $\mathrm{CDCl}_{3}$
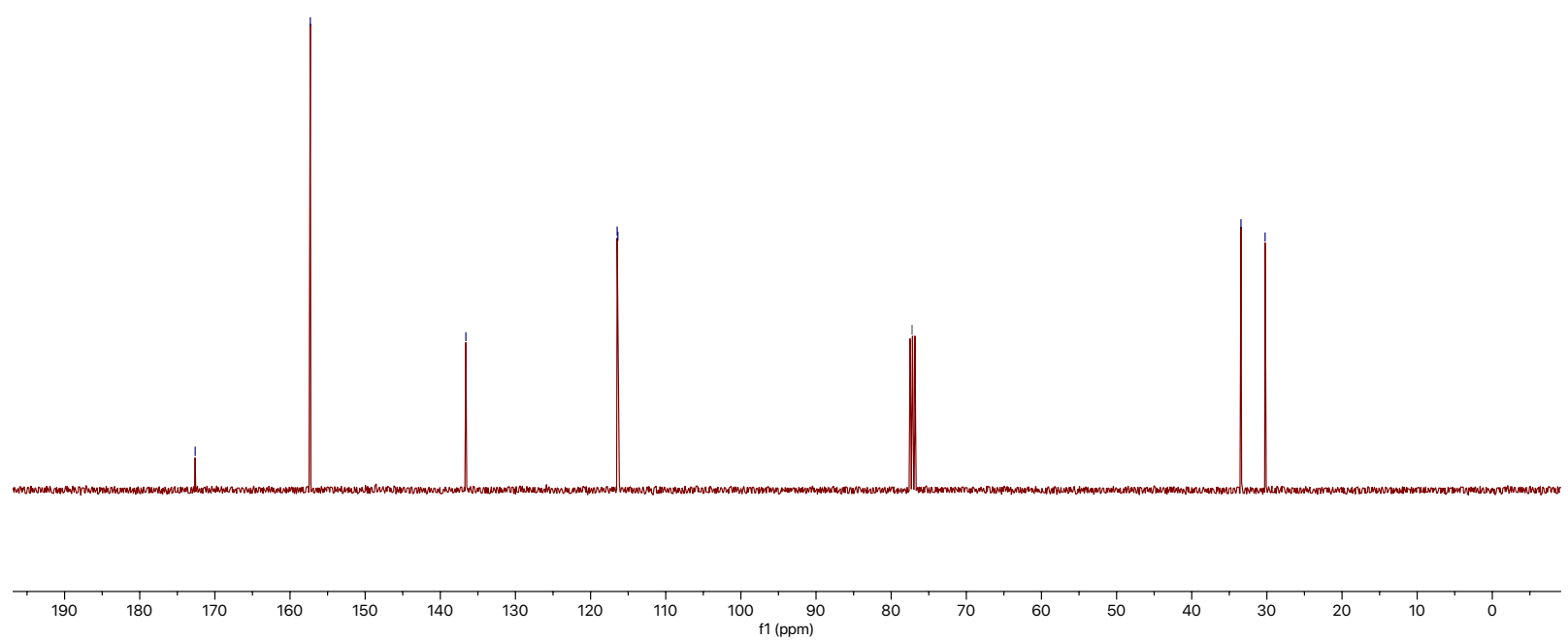


\subsection{NMR Spectra of Olefin Hydroalkenylation Products}
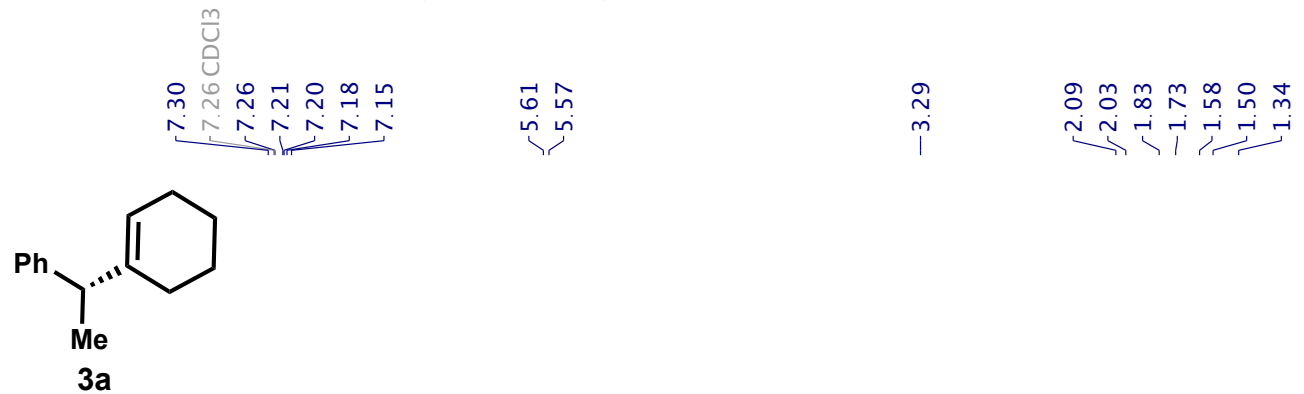

${ }^{1} \mathrm{H}$ NMR, $500 \mathrm{MHz}, \mathrm{CDCl}_{3}$

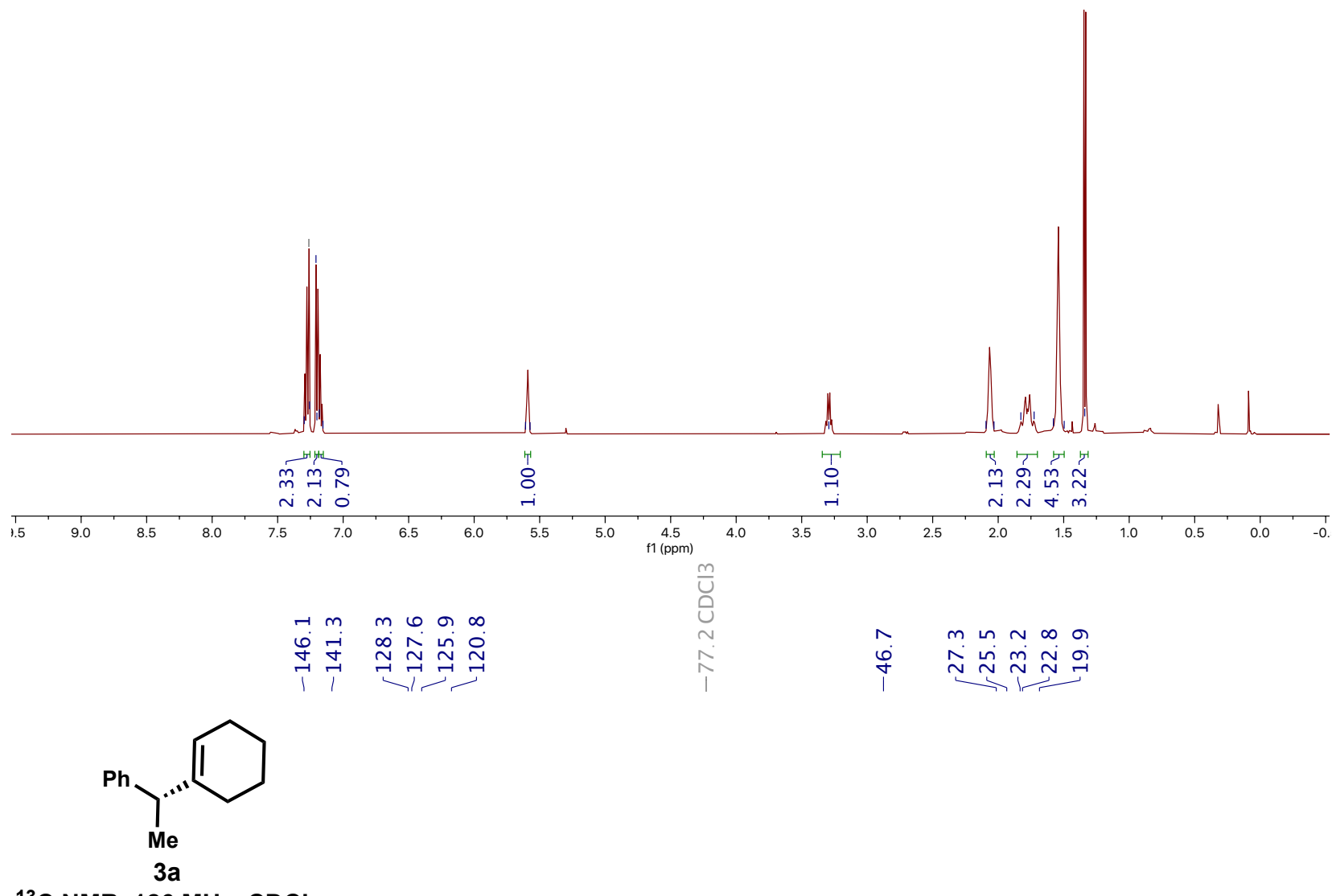

${ }^{13} \mathrm{C}$ NMR, $126 \mathrm{MHz}, \mathrm{CDCl}_{3}$

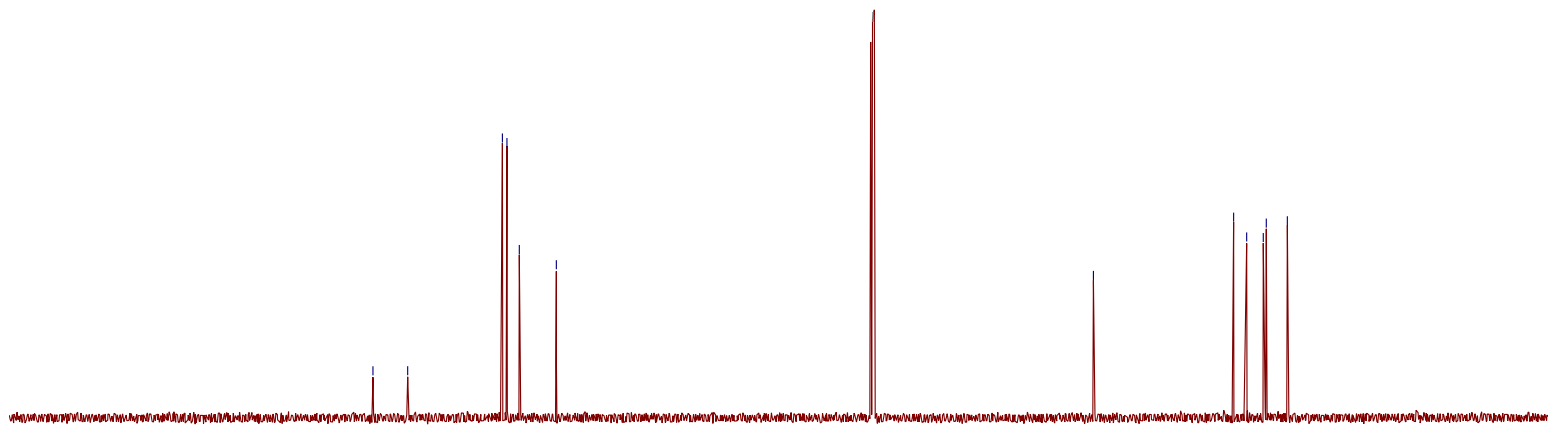

$\begin{array}{lllll}190 & 180 & 170 & 160 & 150\end{array}$ 
Supporting Information

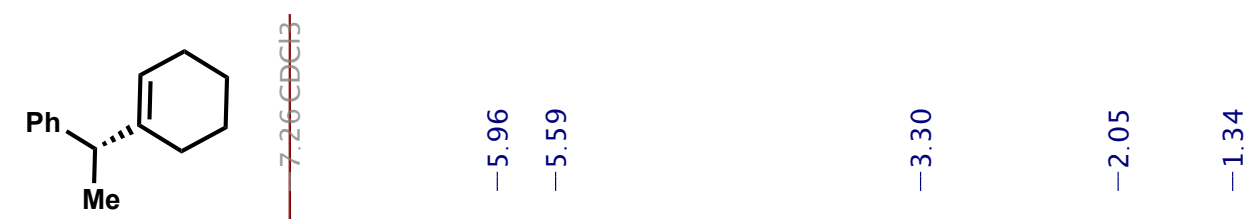

3a, Crude reaction mixture with TCE

${ }^{1} \mathrm{H}$ NMR, $500 \mathrm{MHz}^{\mathrm{CDCl}_{3}}$

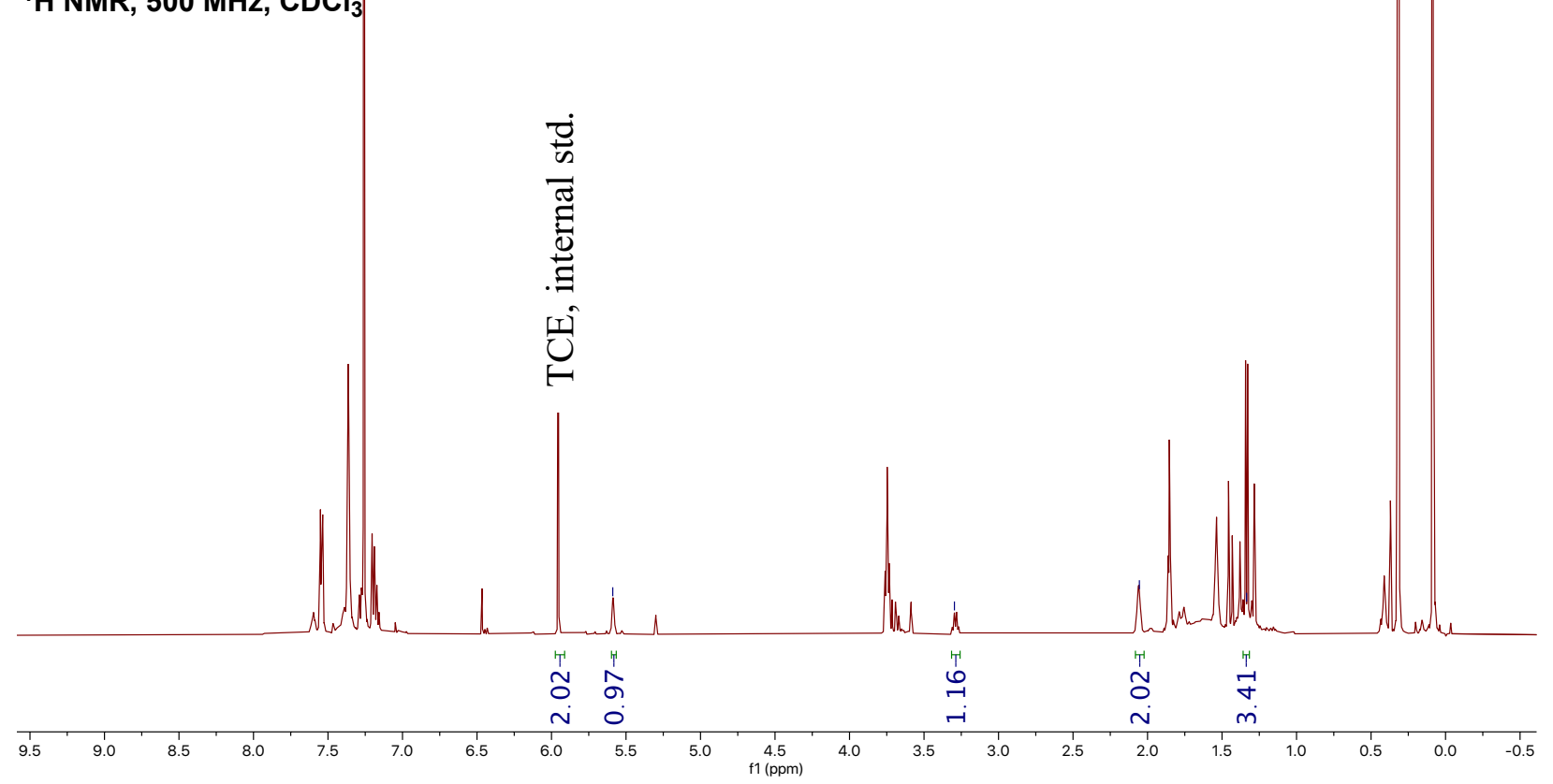




\section{Supporting Information}
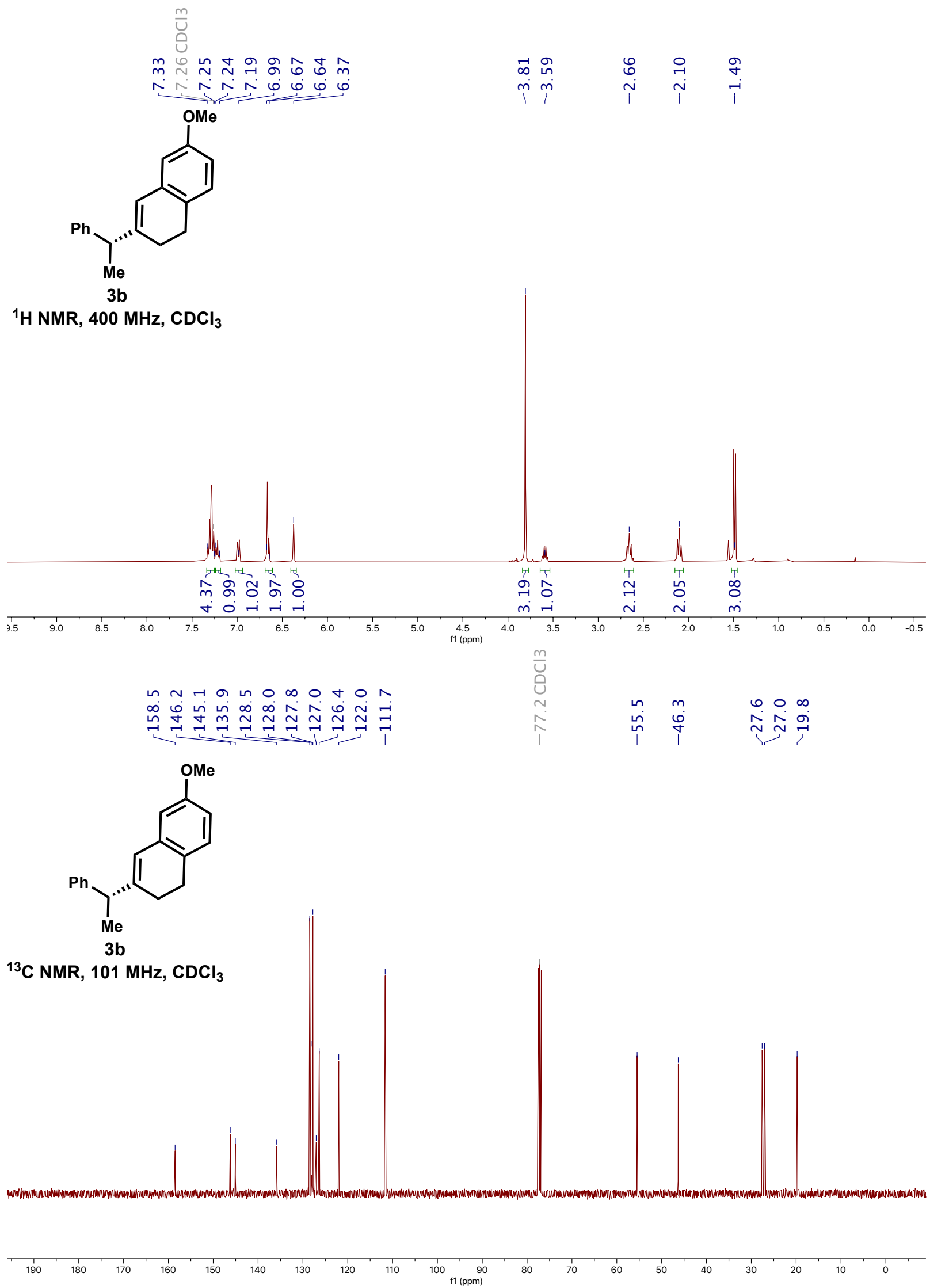


\section{Supporting Information}

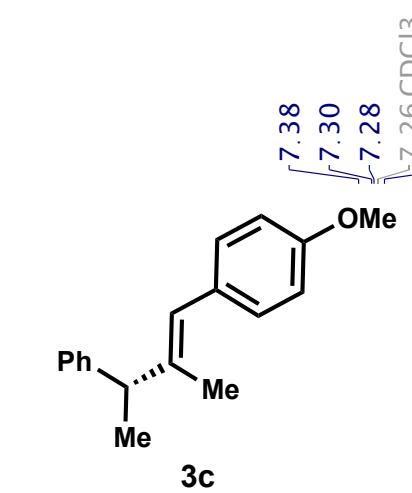

${ }^{1} \mathrm{H}$ NMR, $400 \mathrm{MHz}^{\mathrm{CDCl}}{ }_{3}$

†

$m_{1}^{\infty} i$

זิ

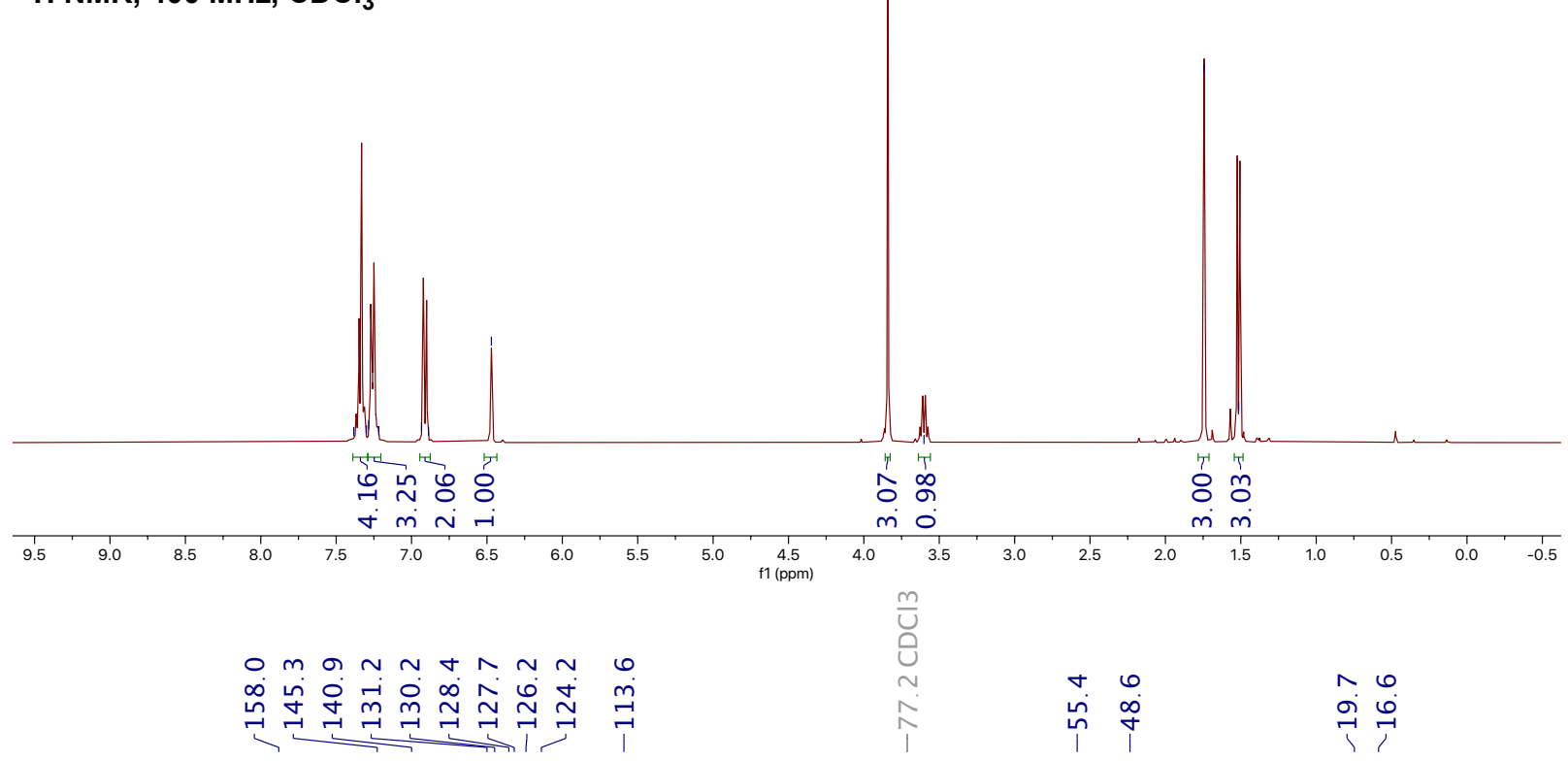<smiles>COc1ccc(/C=C(\C)[C@H](C)c2ccccc2)cc1</smiles>

3c

${ }^{13} \mathrm{C}$ NMR, $101 \mathrm{MHz}, \mathrm{CDCl}_{3}$

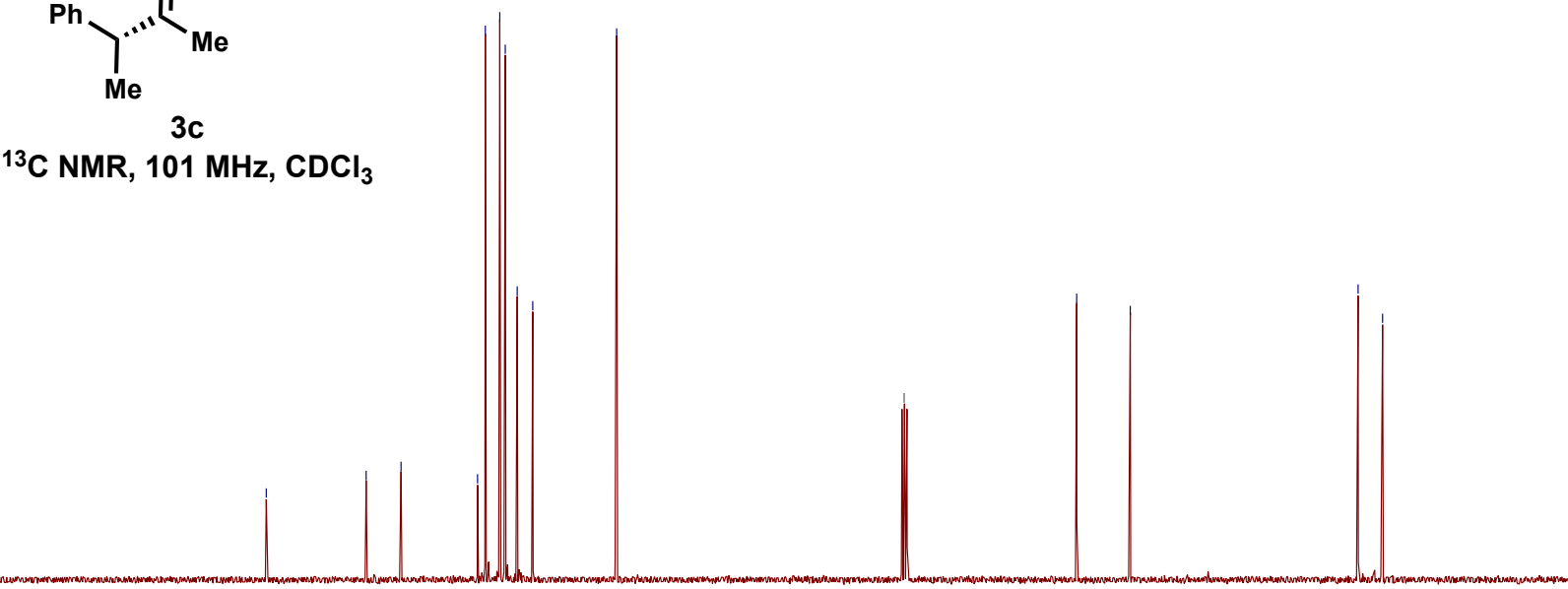

190

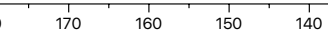

90
$\mathrm{f} 1(\mathrm{ppm})$ 
Supporting Information

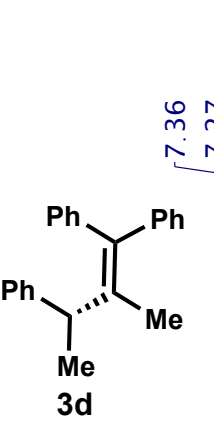

${ }^{1} \mathrm{H}$ NMR, $400 \mathrm{MHz}, \mathrm{CDCl}_{3}$
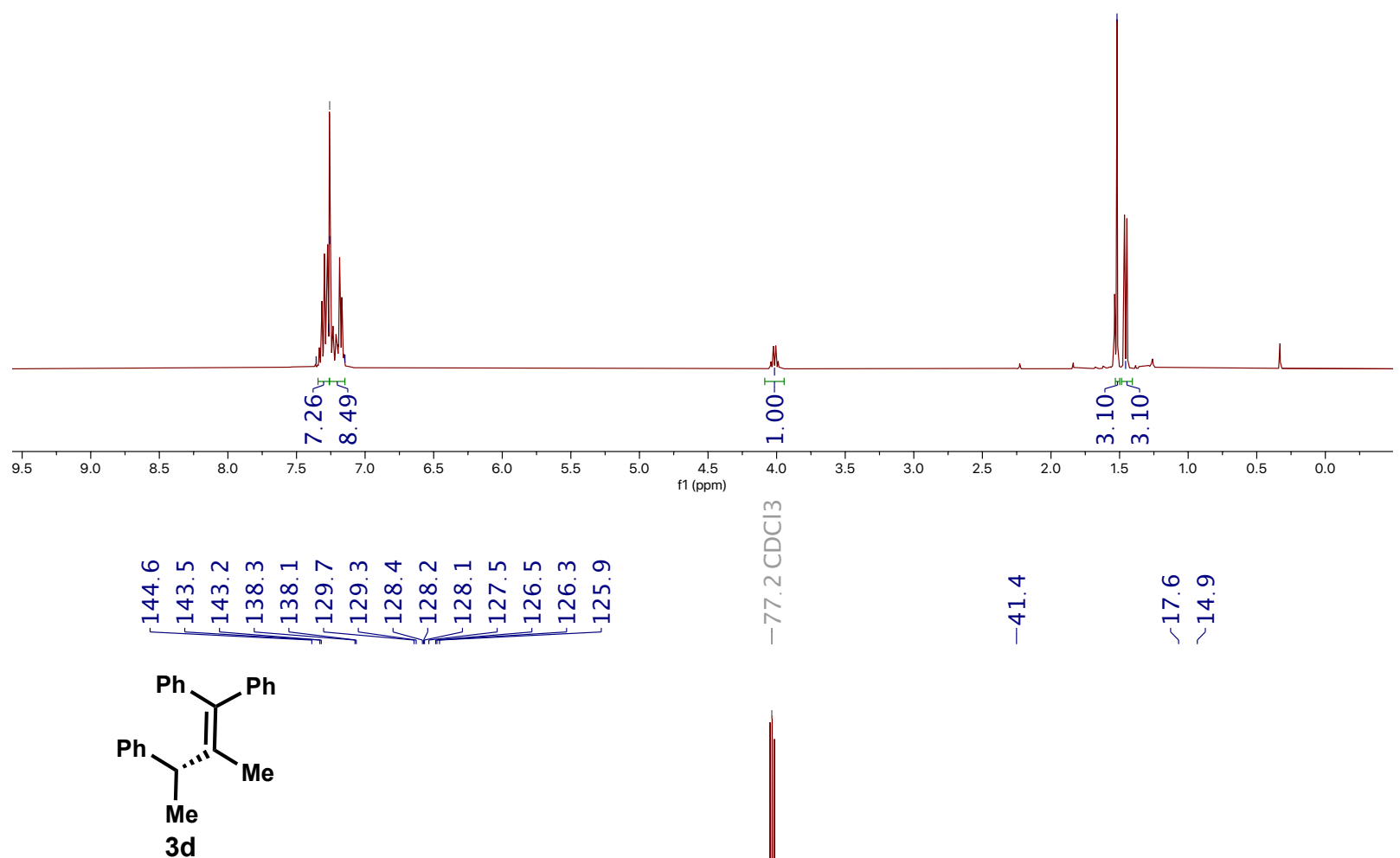

${ }^{13} \mathrm{C}$ NMR, $101 \mathrm{MHz}, \mathrm{CDCl}_{3}$

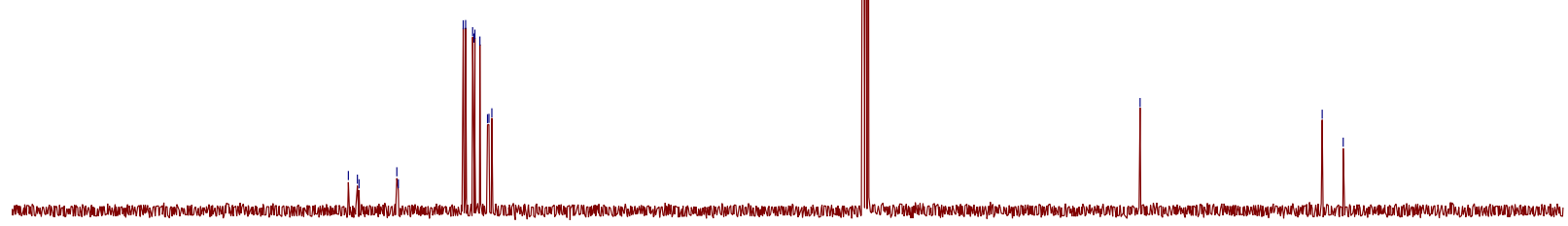


Supporting Information
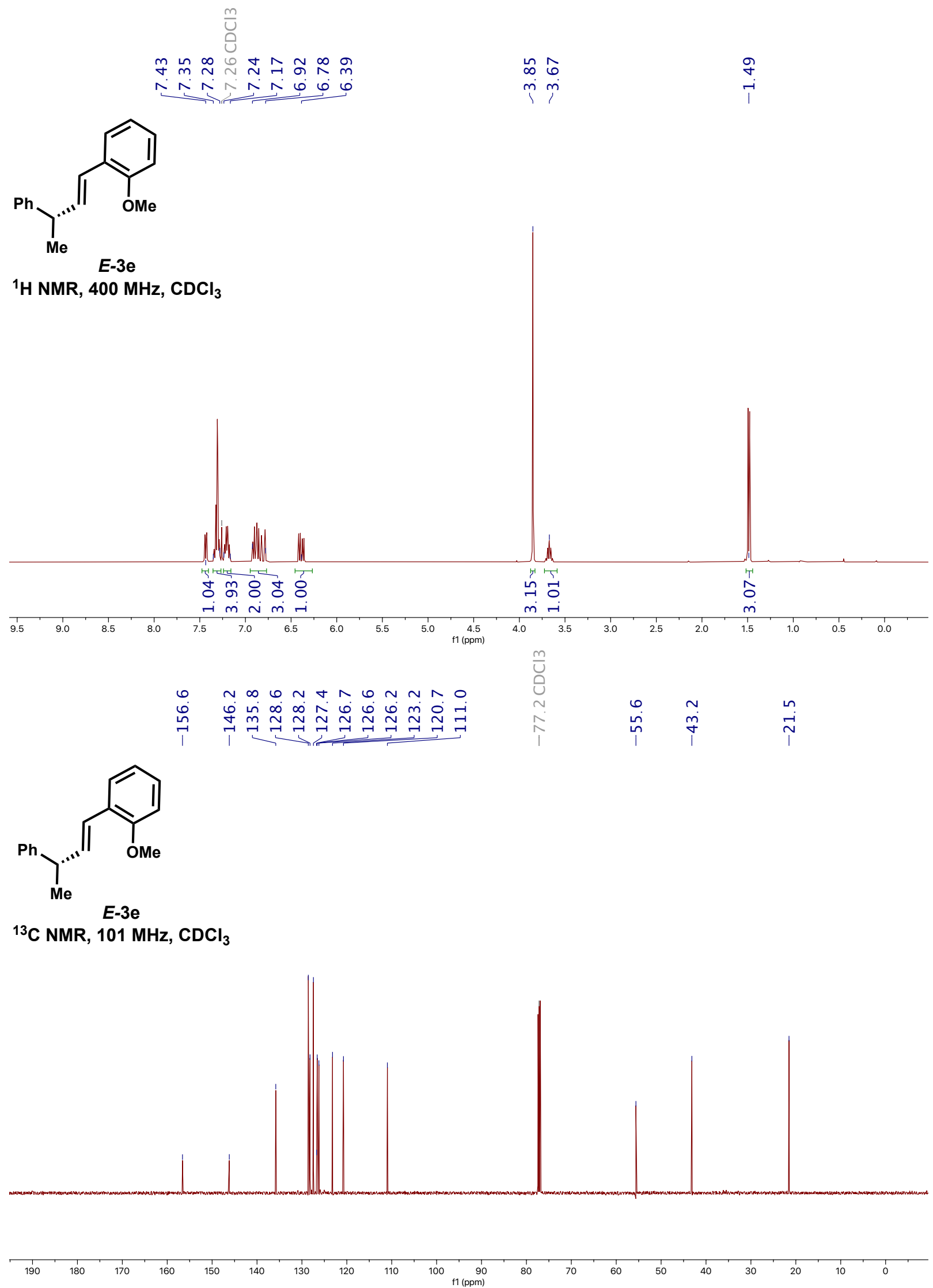


\section{Supporting Information}
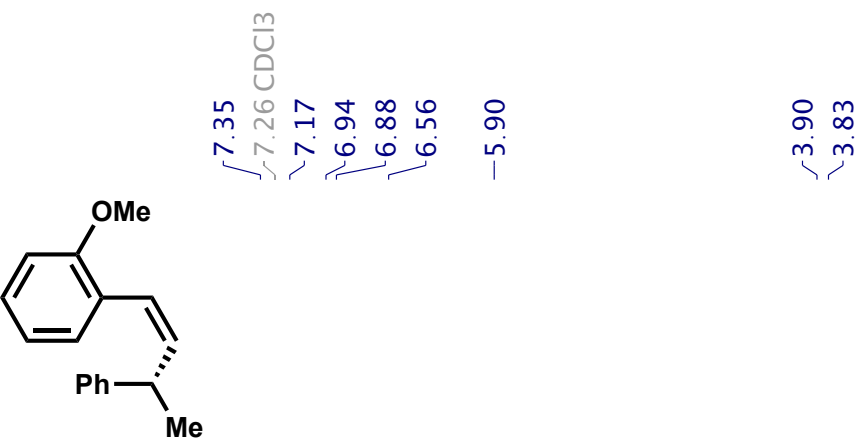

$\underset{\substack{m \\ \text { I }}}{\infty}$

Z-3e

${ }^{1} \mathrm{H}$ NMR, $400 \mathrm{MHz}^{\mathrm{CDCl}}{ }_{3}$

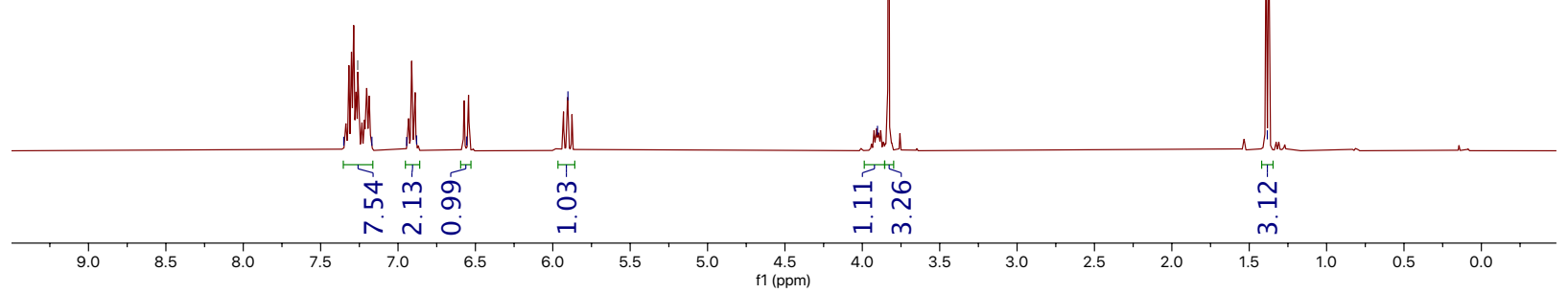

$m \omega 0-16 \nabla r \forall-r \ln \sim 6$

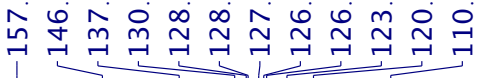

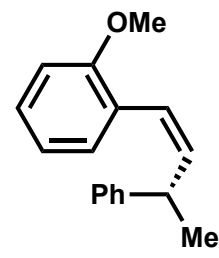

Z-3e

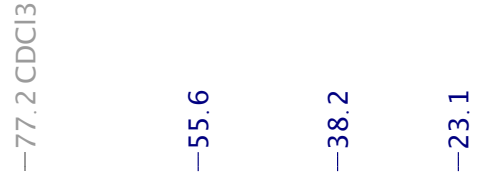

${ }^{3} \mathrm{NMR}, 101 \mathrm{MHz}, \mathrm{CDCl}_{3}$
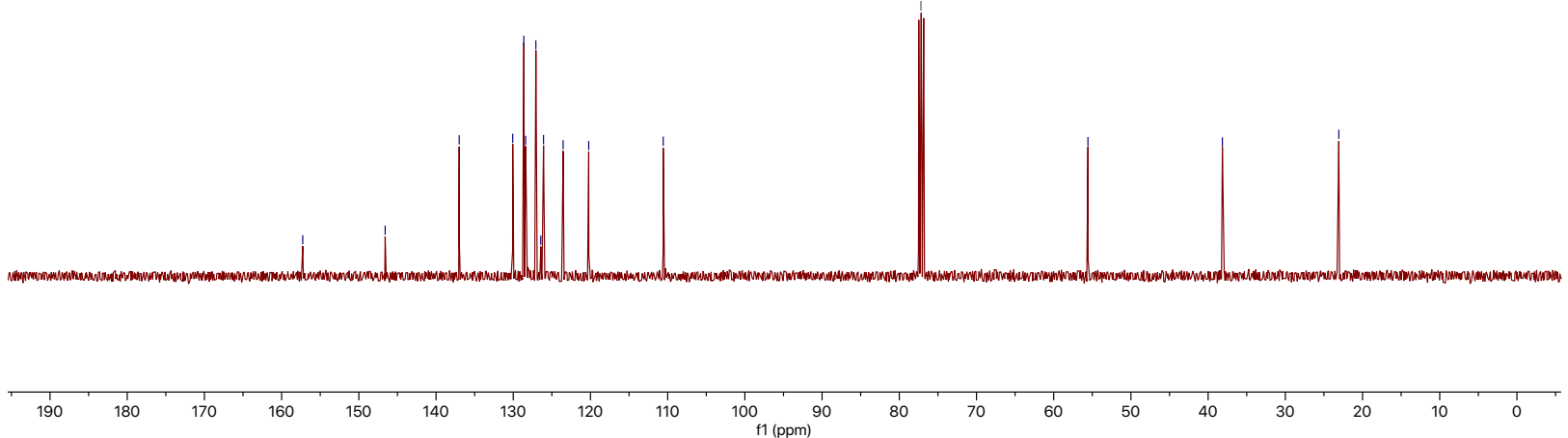
Supporting Information

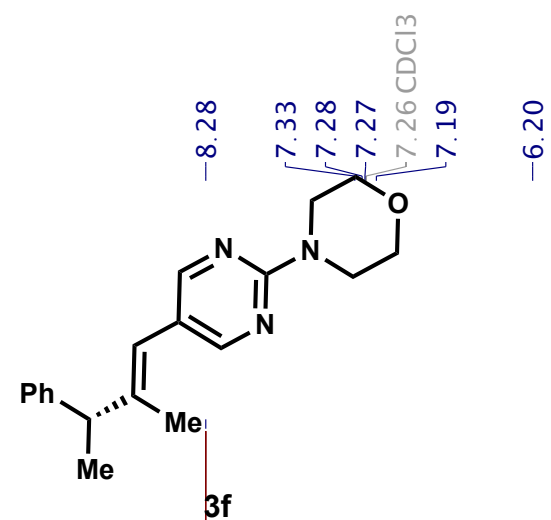

- $\infty \stackrel{\infty}{\wedge} \stackrel{n}{\wedge}$

$\dot{m m m}$

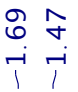

${ }^{1} \mathrm{H}$ NMR, $400 \mathrm{MHz}, \mathrm{CDCl}_{3}$

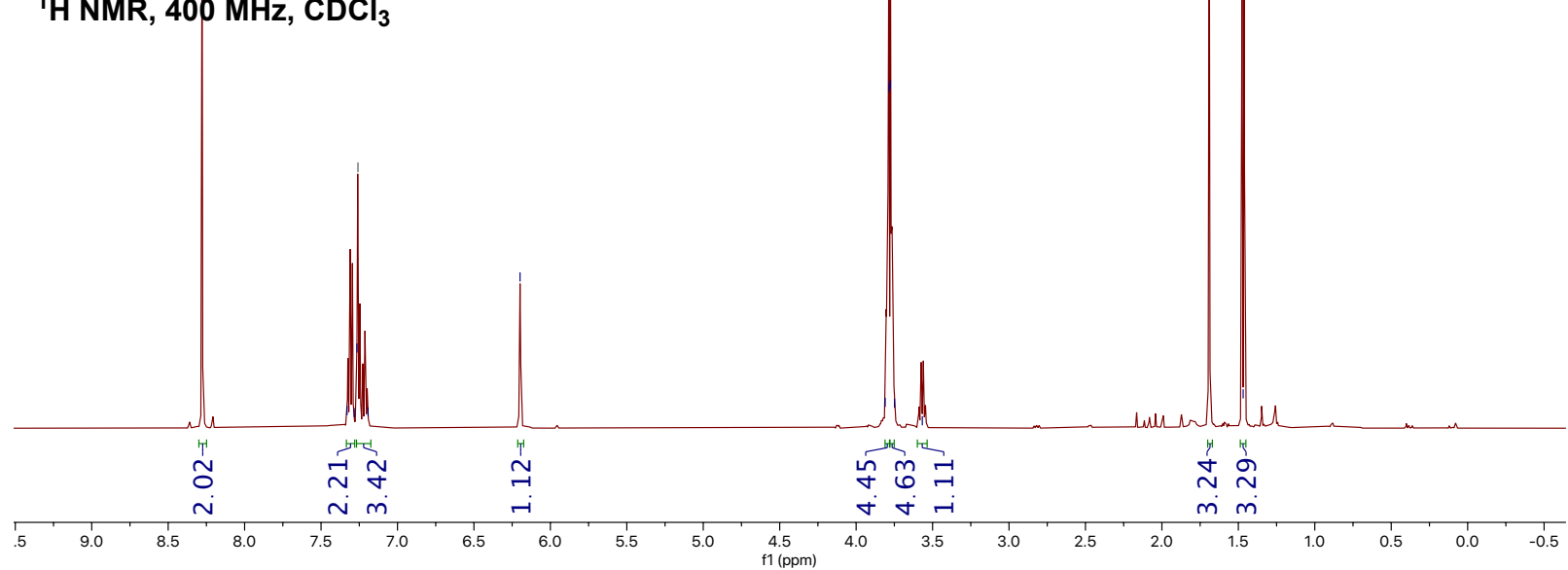

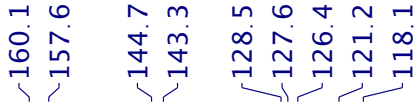<smiles>C/C(=C\c1cnc(N2CCOCC2)nc1)[C@H](C)c1ccccc1</smiles>

${ }^{13} \mathrm{C}$ NMR, $101 \mathrm{MHz}, \mathrm{CDCl}_{3}$

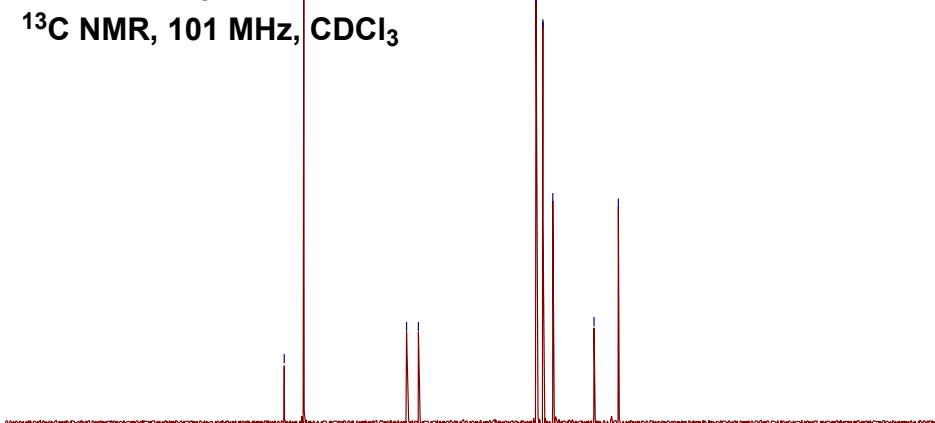

$\wedge \infty$

국

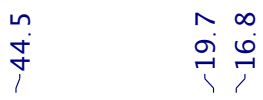


Supporting Information

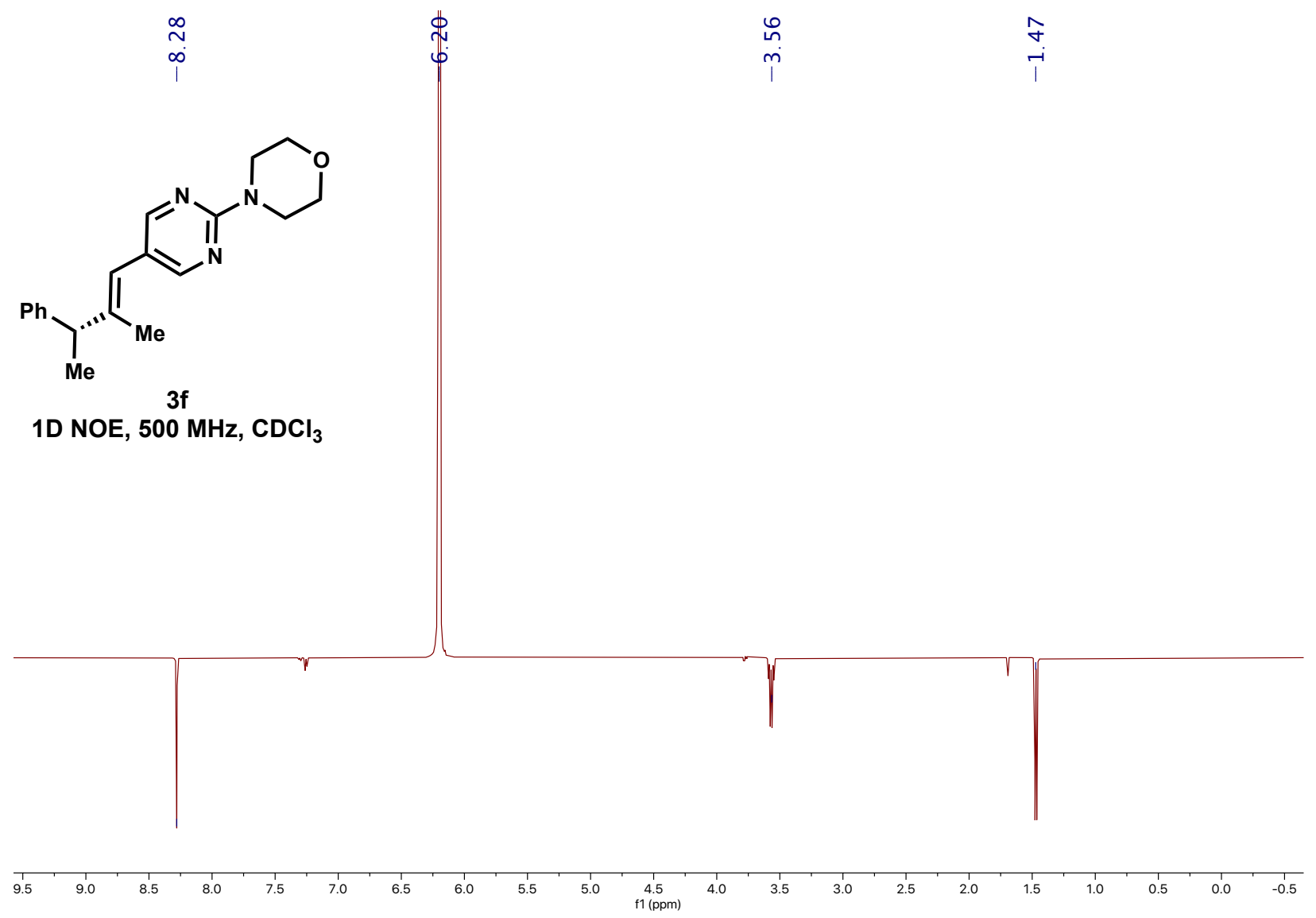


Supporting Information
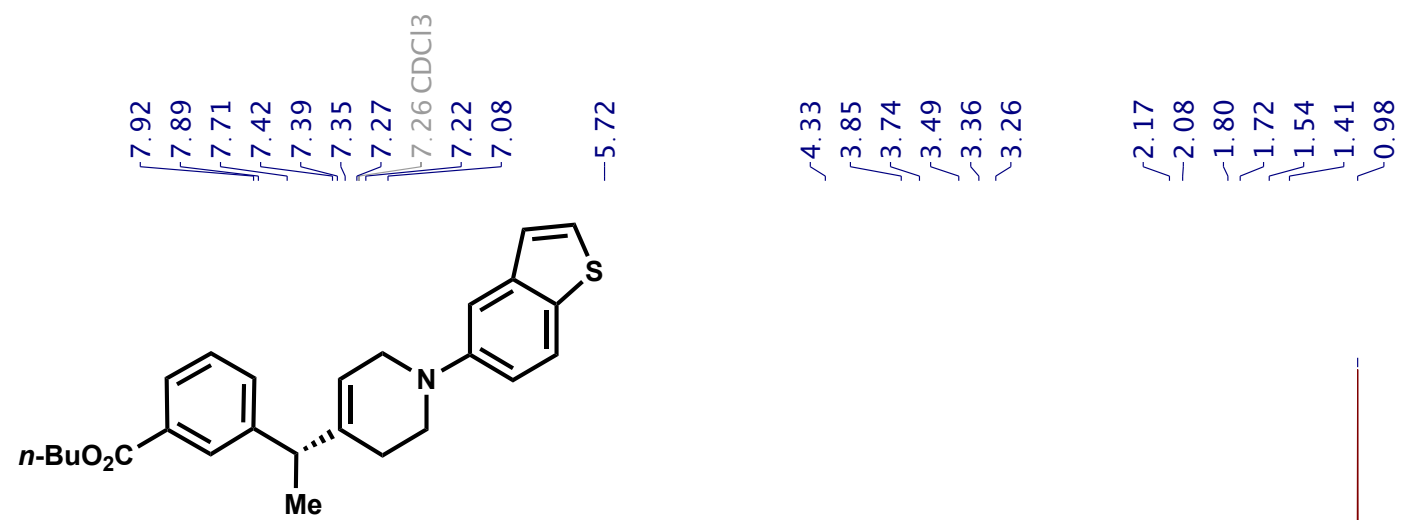

$3 \mathrm{~g}$

${ }^{1} \mathrm{H}$ NMR, $400 \mathrm{MHz}^{\mathrm{CDCl}_{3}}$

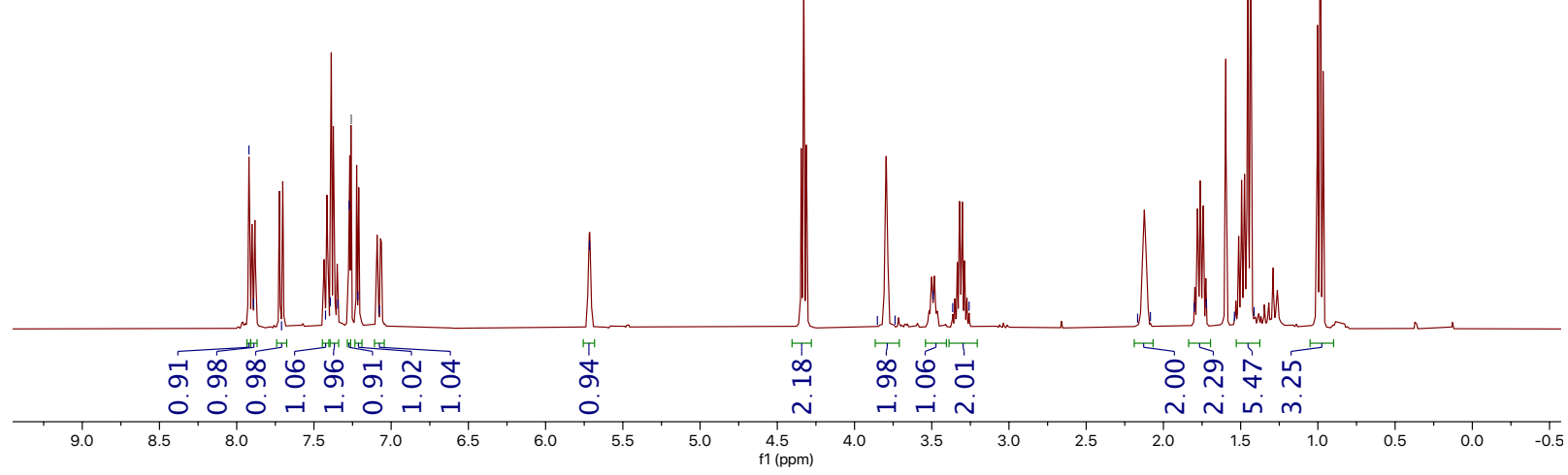

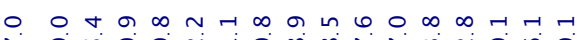

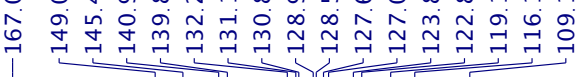

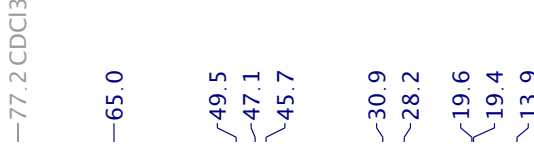<smiles>CCCCOC(=O)c1cccc([C@H](C)C2=CCN(c3ccc4sccc4c3)CC2)c1</smiles>

$3 \mathrm{~g}$

${ }^{13} \mathrm{C}$ NMR, $101 \mathrm{MHz}, \mathrm{CDCl}_{3}$

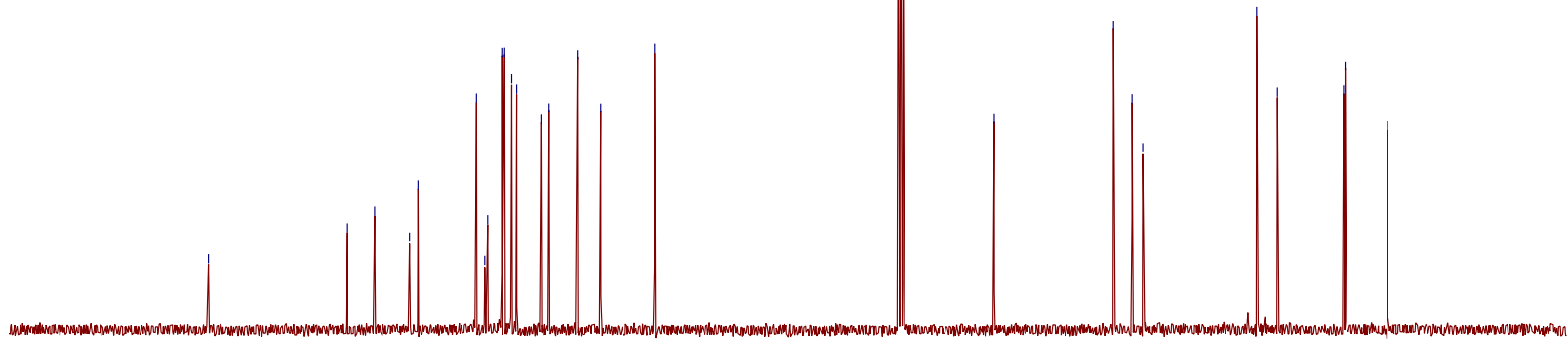

190

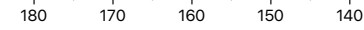

$120 \quad 110$

90
$1(\mathrm{ppm})$ 
Supporting Information
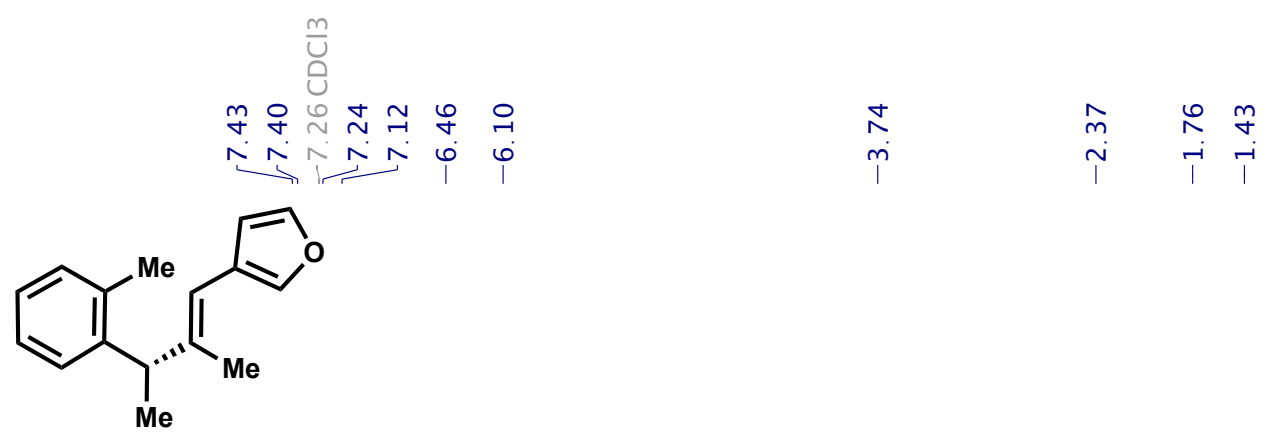

$3 \mathrm{~h}$

${ }^{1} \mathrm{H}$ NMR, $500 \mathrm{MHz}, \mathrm{CDCl}_{3}$

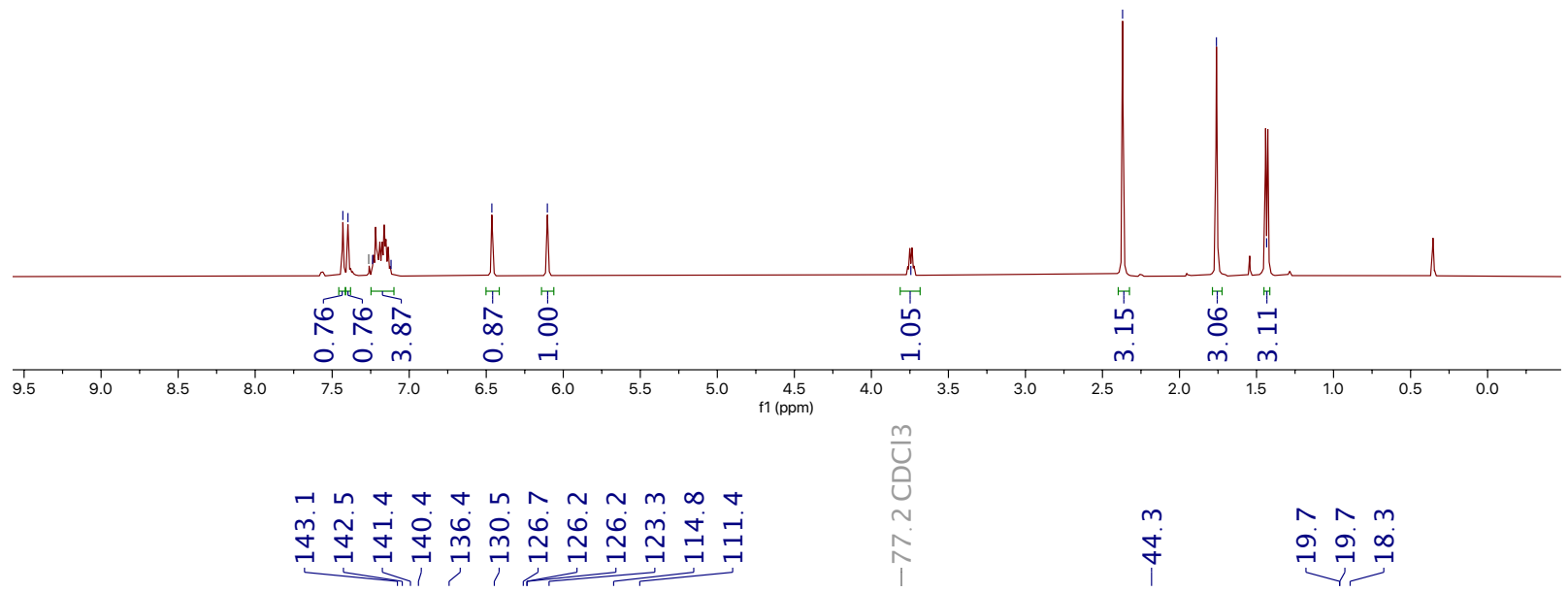<smiles>CC(=Cc1ccoc1)[C@@H](C)c1ccccc1C</smiles>

$3 \mathrm{~h}$

${ }^{13} \mathrm{C} \mathrm{NMR}, 126 \mathrm{MHz}, \mathrm{CDCl}_{3}$
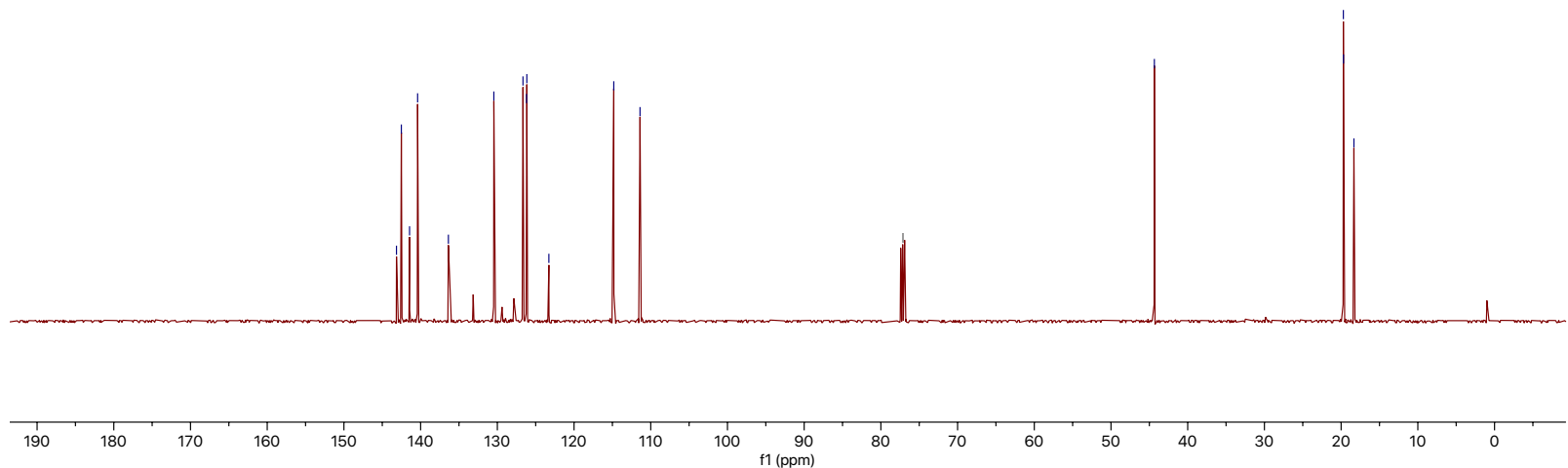
Supporting Information

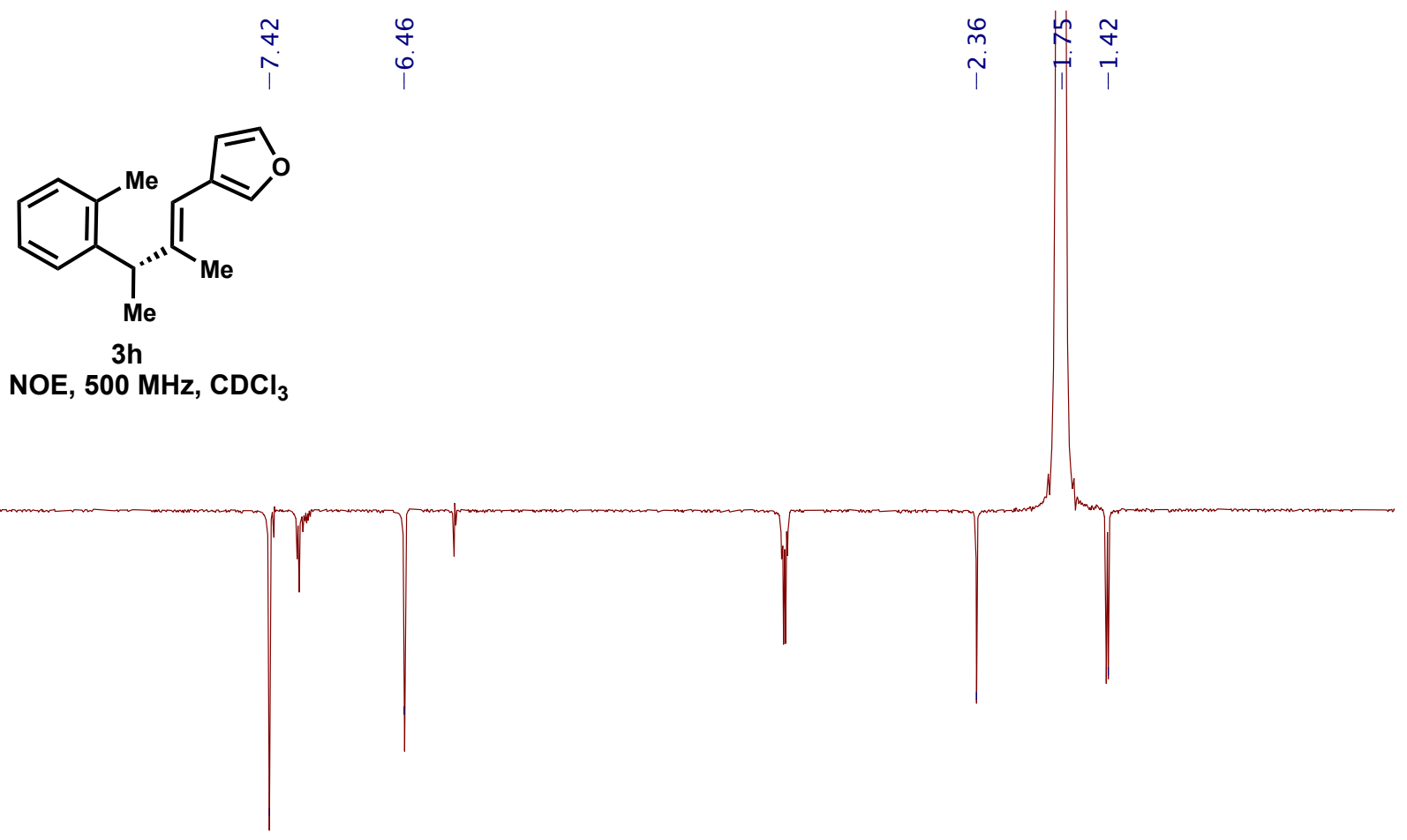

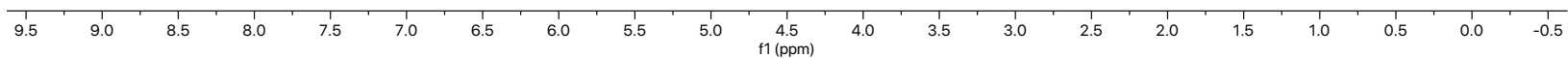


Supporting Information
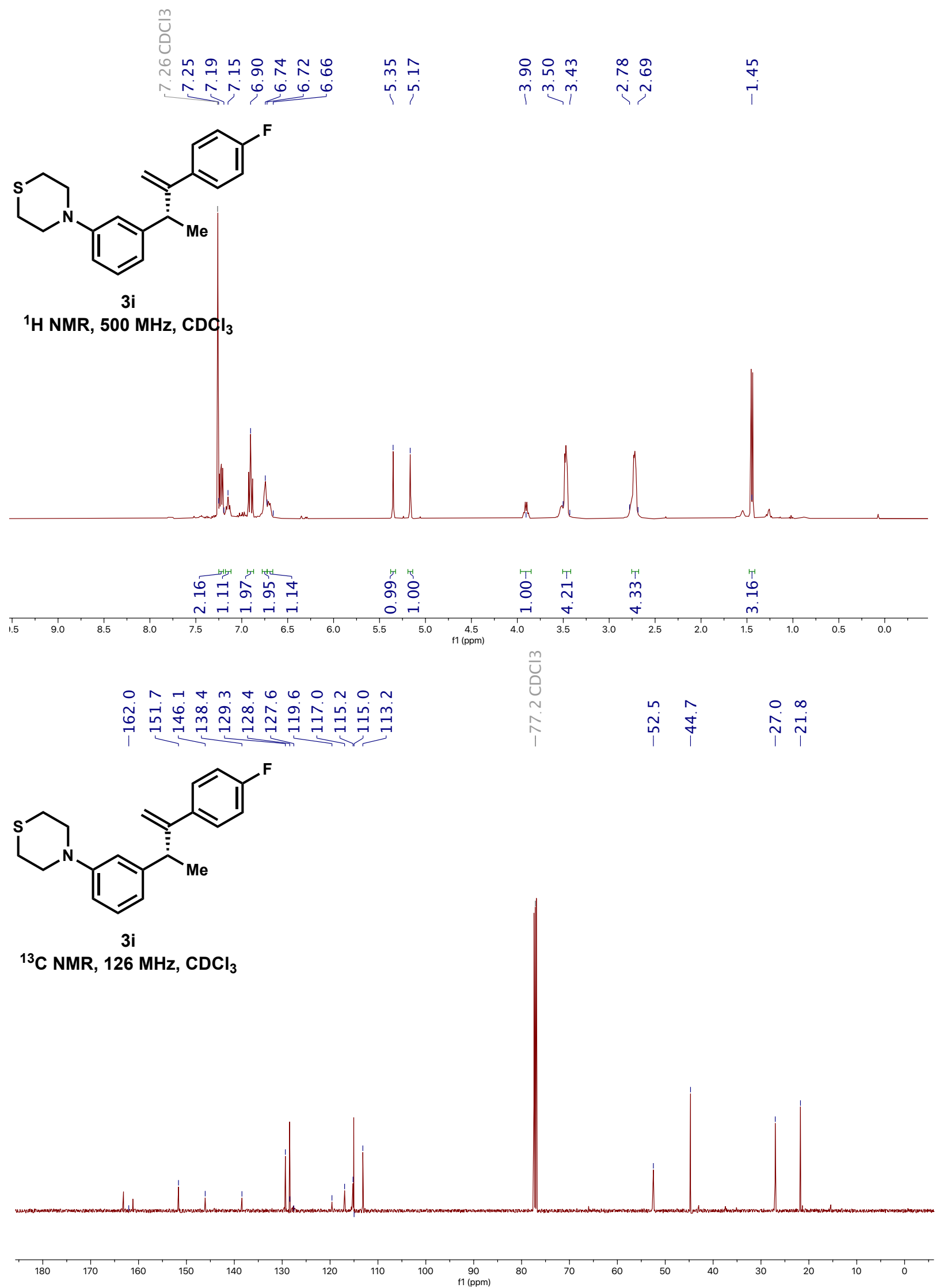
Supporting Information<smiles>C=C(c1ccc(F)cc1)[C@H](C)c1cccc(N2CCSCC2)c1</smiles>

3i

${ }^{19} \mathrm{~F}$ NMR, $471 \mathrm{MHz}, \mathrm{CDCl}_{3}$

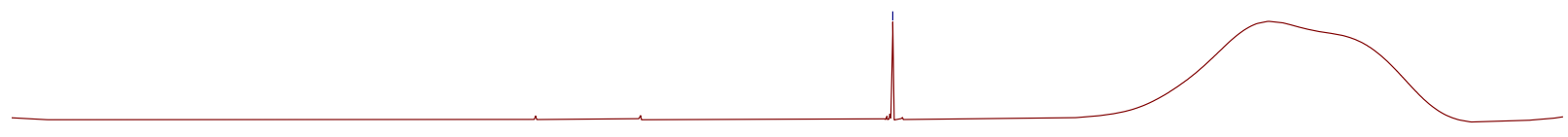

\begin{tabular}{lllllllllllllllllllllll}
\hline 10 & 0 & -10 & -20 & -30 & -40 & -50 & -60 & -70 & -80 & -90 & -100 & -110 & -120 & -130 & -140 & -150 & -160 & -170 & -180 & -190 & -200 & -210 \\
\hline 10
\end{tabular}


Supporting Information
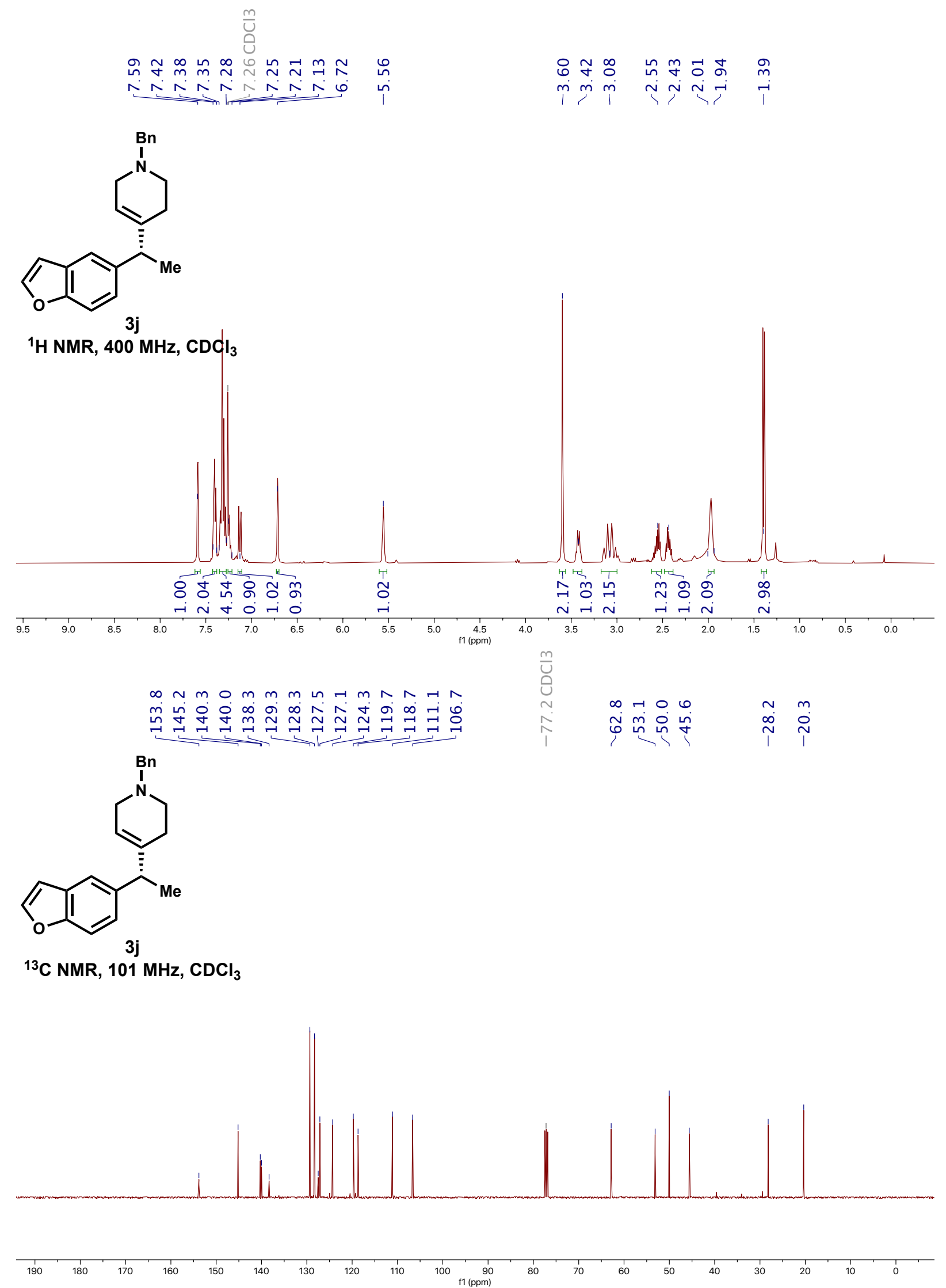
Supporting Information

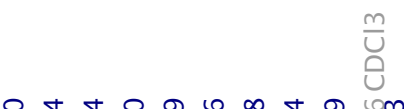

이 \}

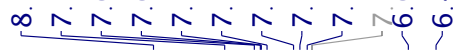

$\ddot{m} \cong$

in in

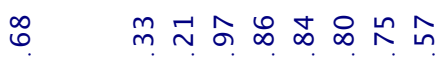

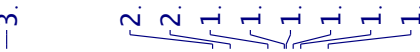<smiles>CC(=Cc1cnc2c(ccn2C2CCCC2)c1)[C@@H](C)c1ccc(-c2ccccc2)cc1</smiles>

${ }^{1} \mathrm{H}$ NMR, $400 \mathrm{MHz}^{\mathrm{CDCl}} \mathrm{C}_{3}$

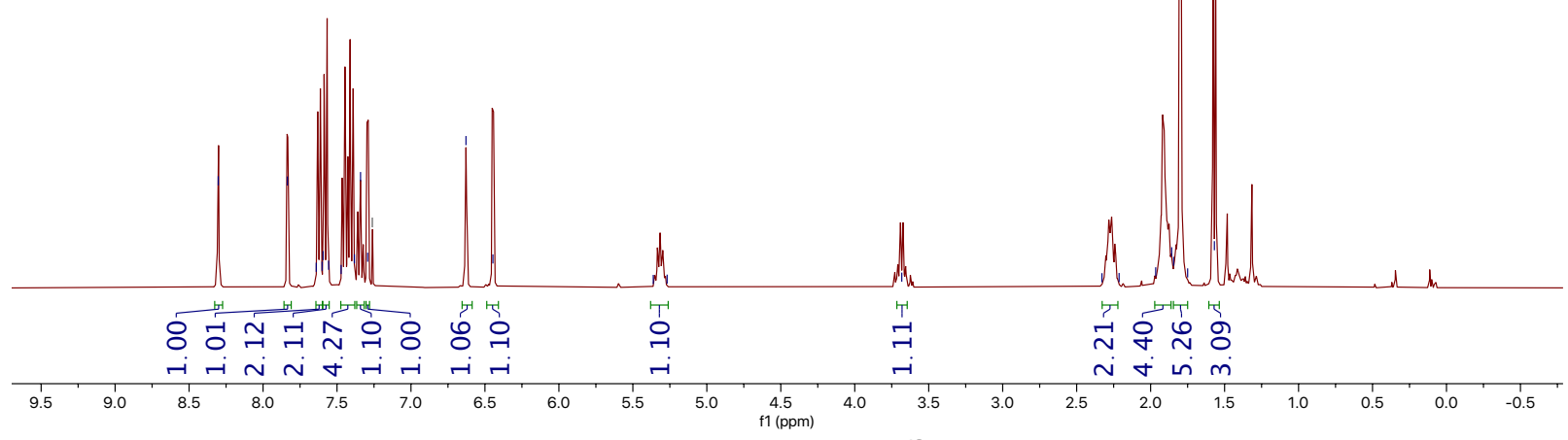

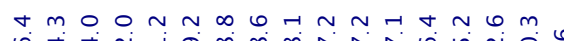

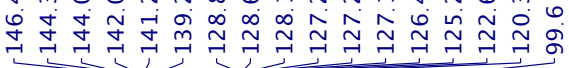
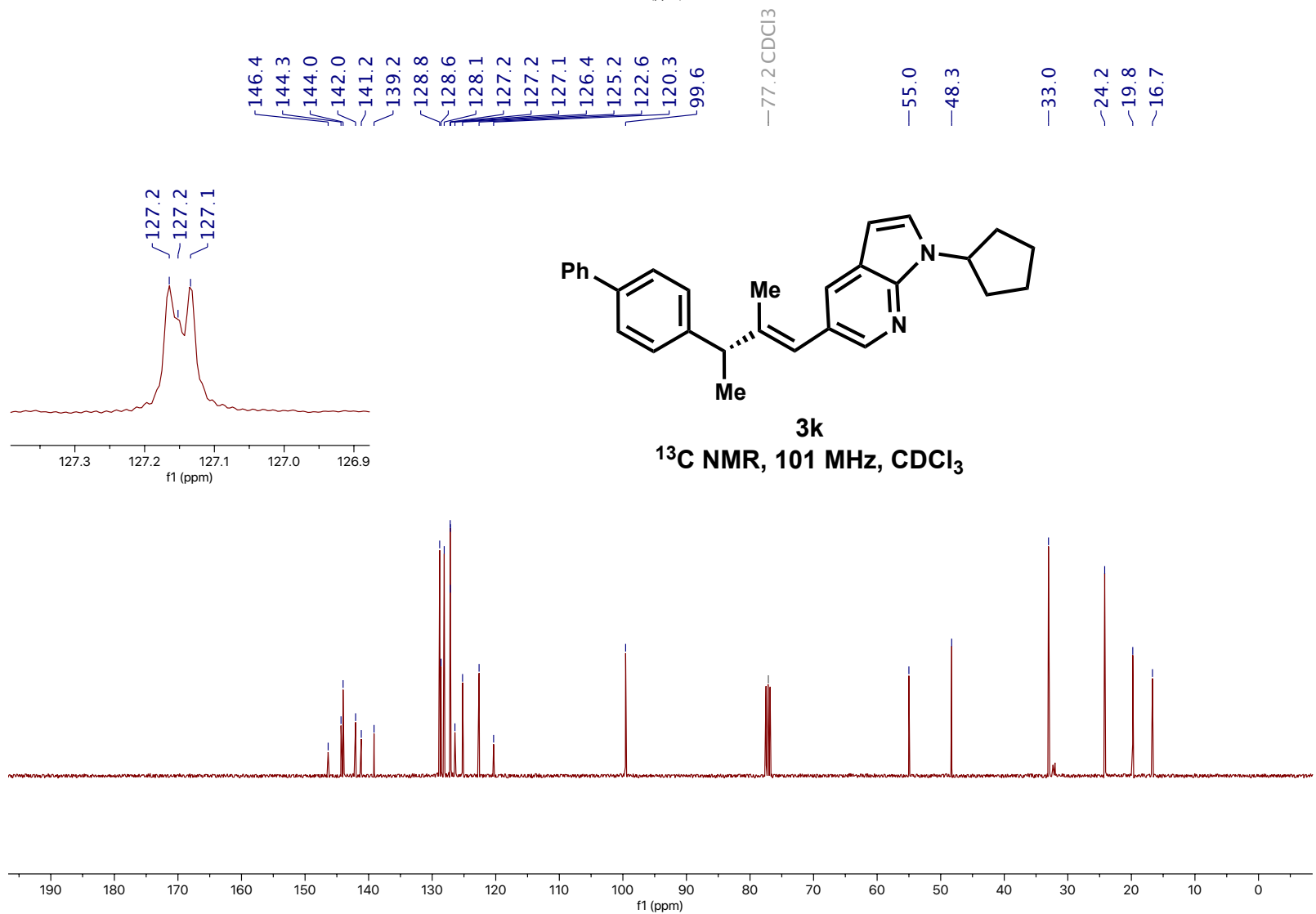
Supporting Information<smiles>COc1ccc(/C=C(\C)[C@H](C)c2ccc(OC)c(Cl)c2)cc1</smiles>

3I

${ }^{1} \mathrm{H}$ NMR, $400 \mathrm{MHz}, \mathrm{CDCl}_{3}$
の $\infty$ ๙

$m i n$

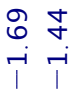

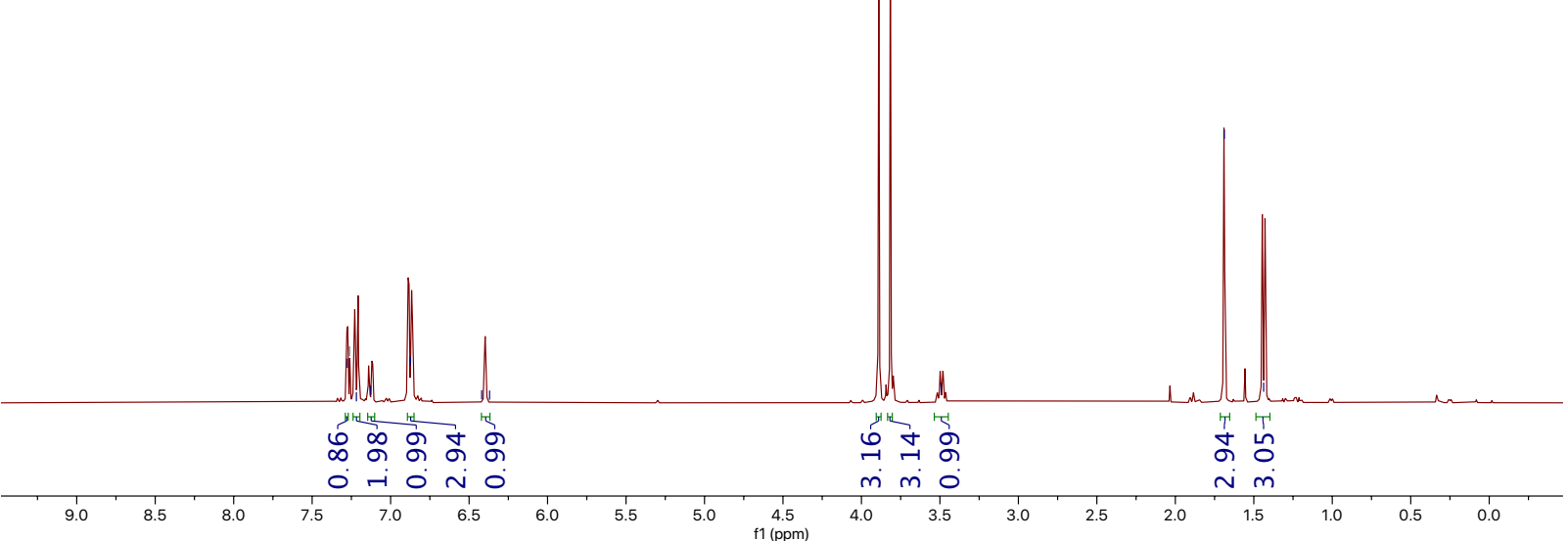

$\circ \forall \operatorname{Ln} 60 \sim+\infty$ in $m \varphi-$

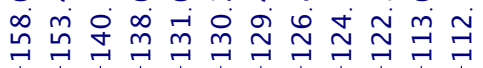

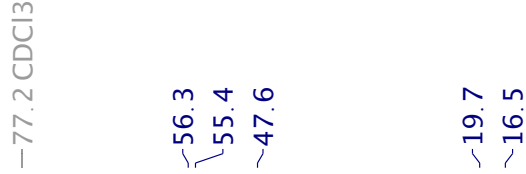<smiles>COc1ccc(/C=C(\C)[C@H](C)c2ccc(OC)c(Cl)c2)cc1</smiles>

3I

${ }^{13} \mathrm{C}$ NMR, $126 \mathrm{MHz}, \mathrm{CDCl}_{3}$

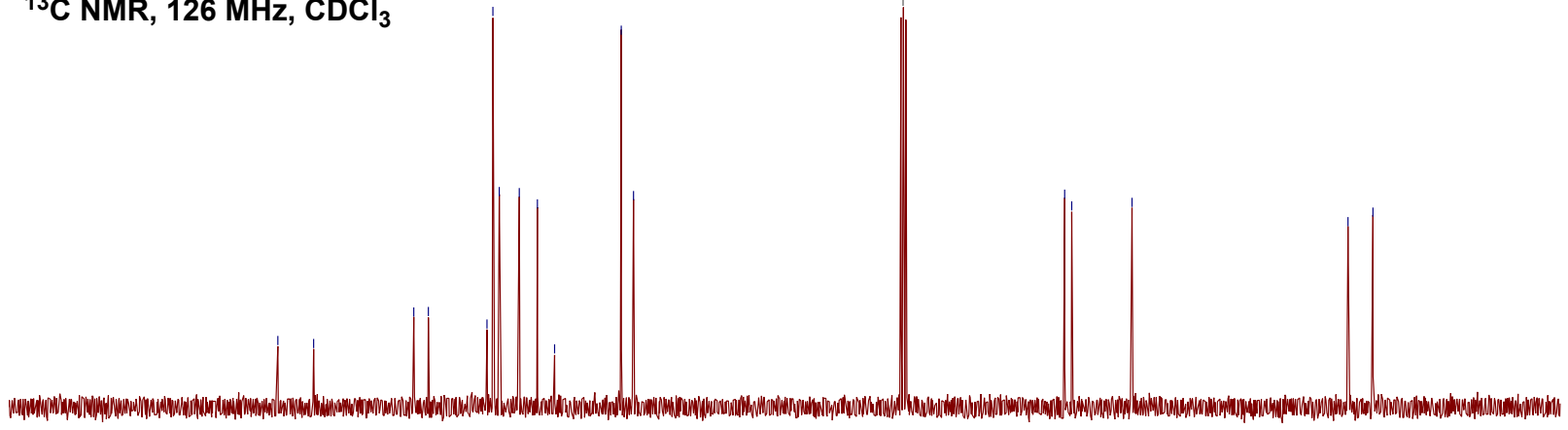

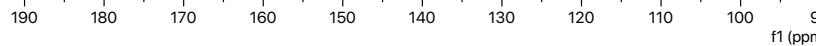


Supporting Information

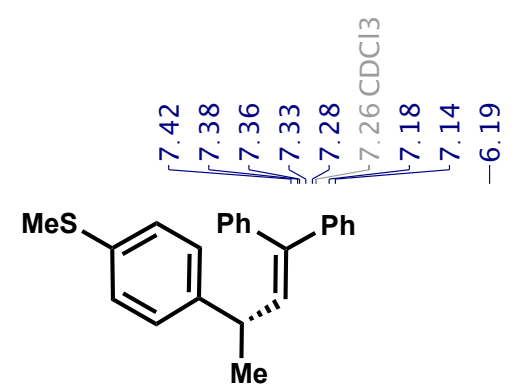

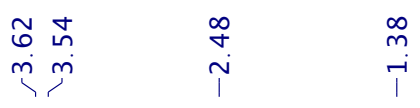

$3 \mathrm{~m}$

${ }^{1} \mathrm{H}$ NMR, $500 \mathrm{MHz}, \mathrm{CDCl}_{3}$

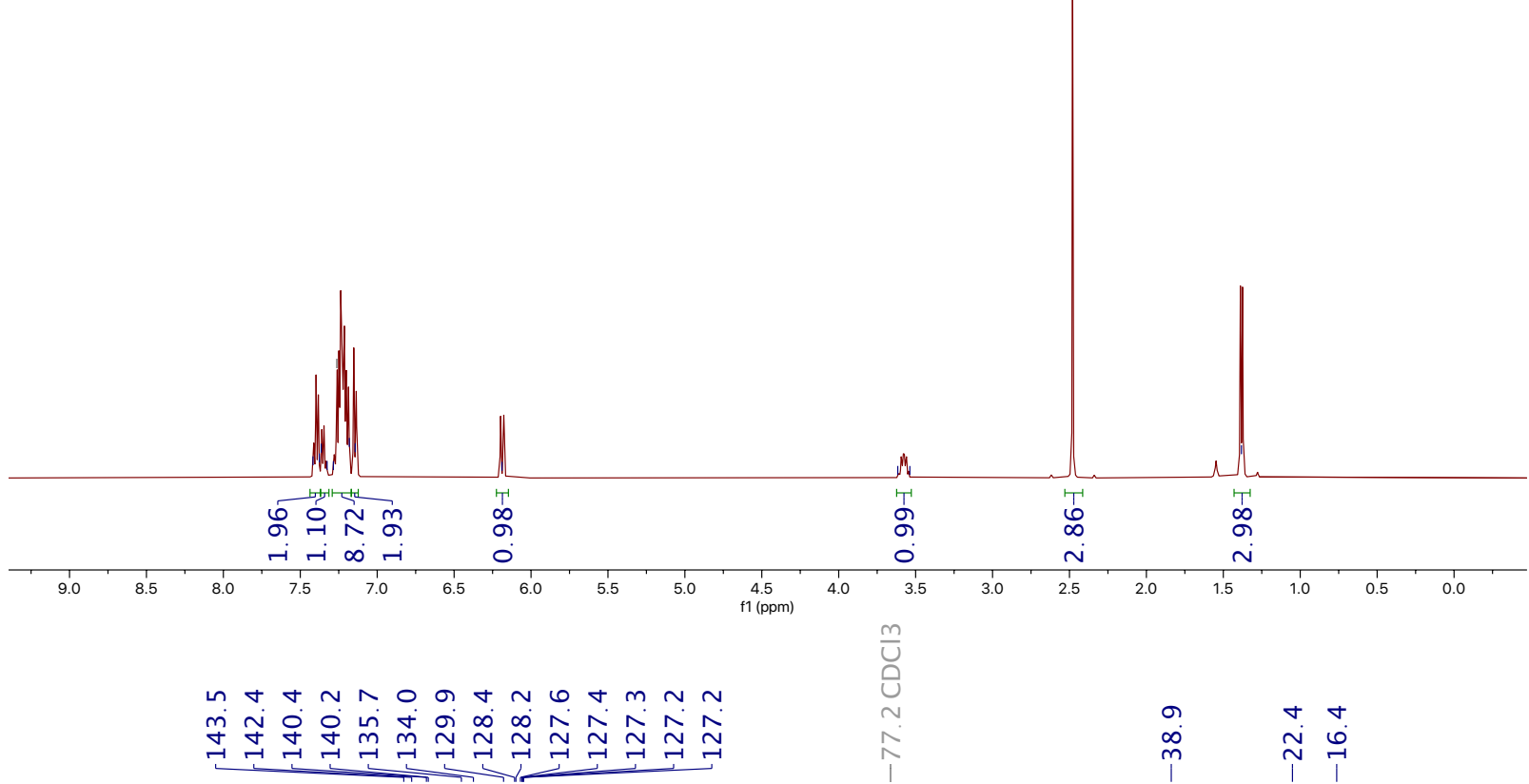<smiles>C[C@H](C=C(c1ccccc1)c1ccccc1)c1ccc(S(C)(=O)=O)cc1</smiles>

$3 m$

${ }^{13} \mathrm{C} \mathrm{NMR}, 126 \mathrm{MHz}, \mathrm{CDCl}_{3}$
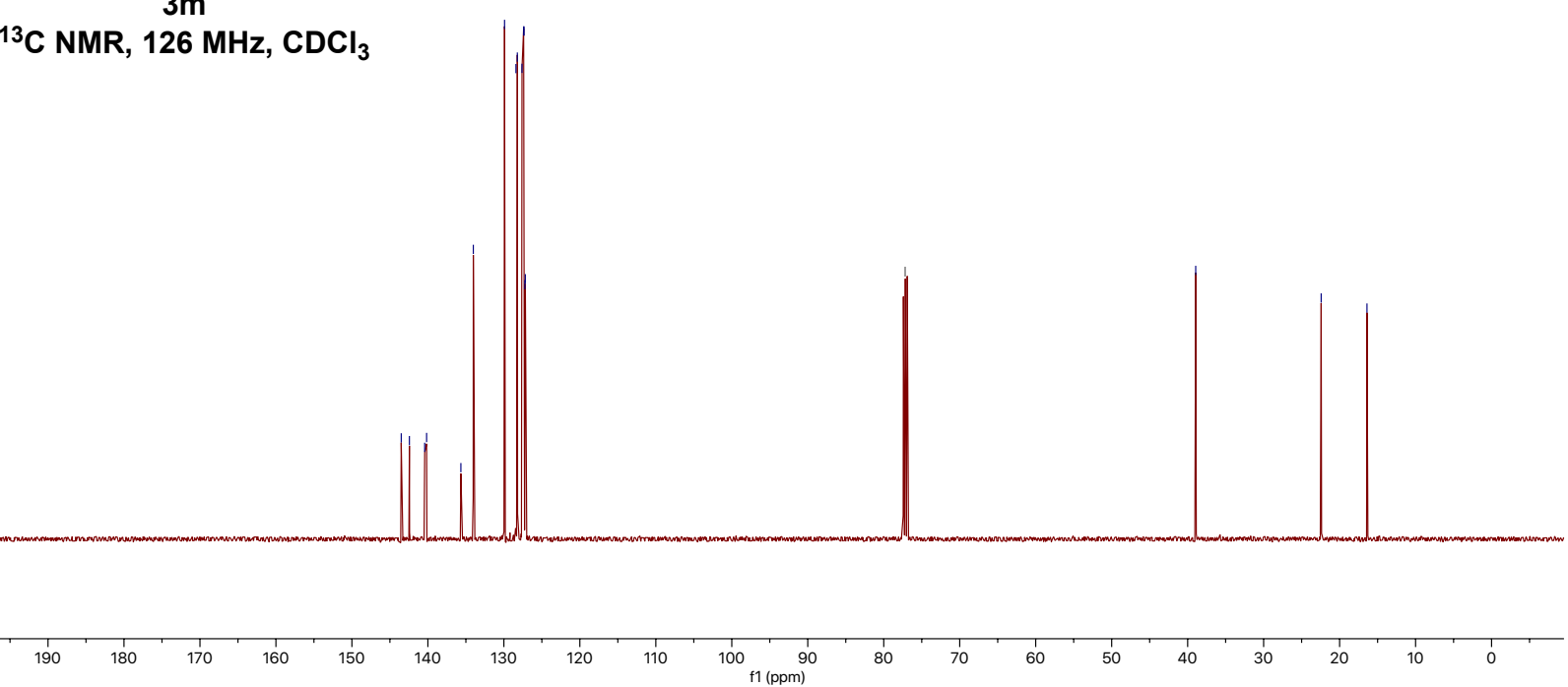
Supporting Information

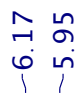

Mes

$3 \mathrm{~m}$, Crude reaction

mixture with TCE

${ }^{1} \mathrm{H}$ NMR, $500 \mathrm{MHz}, \mathrm{CDCl}_{3}$

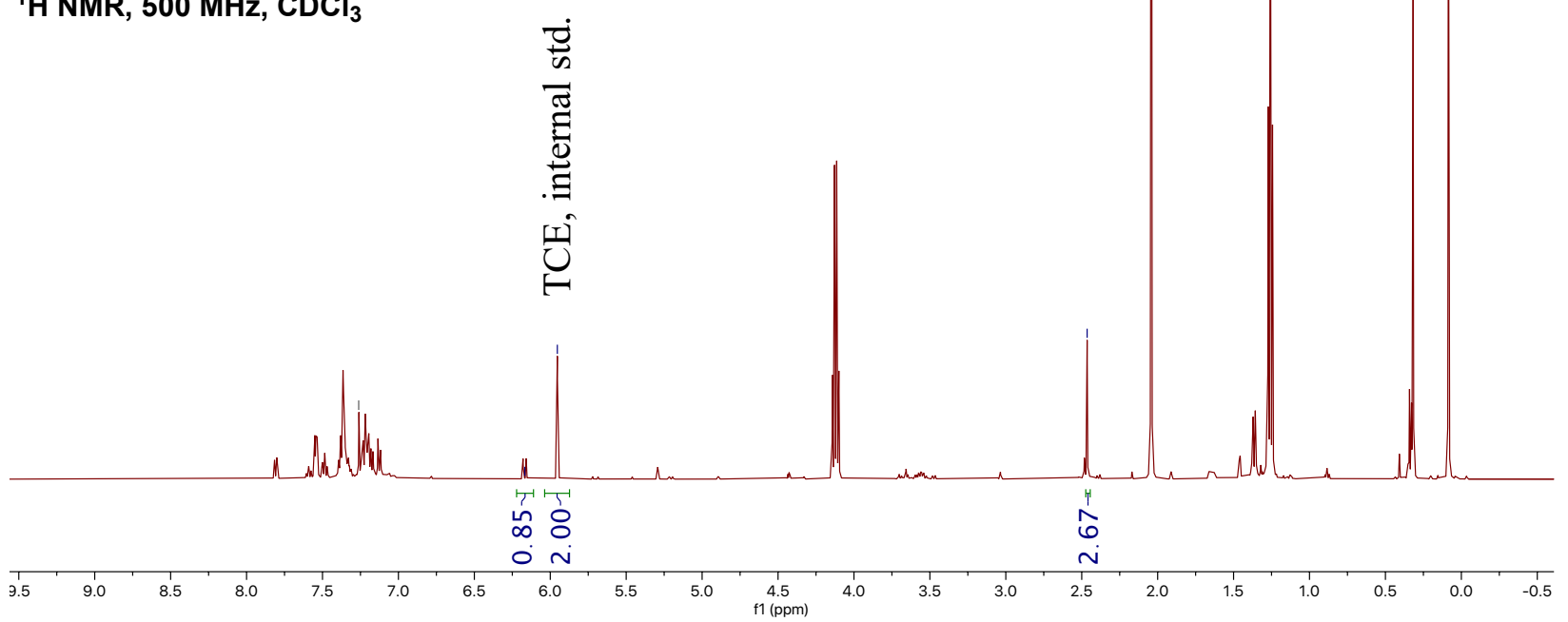


Supporting Information
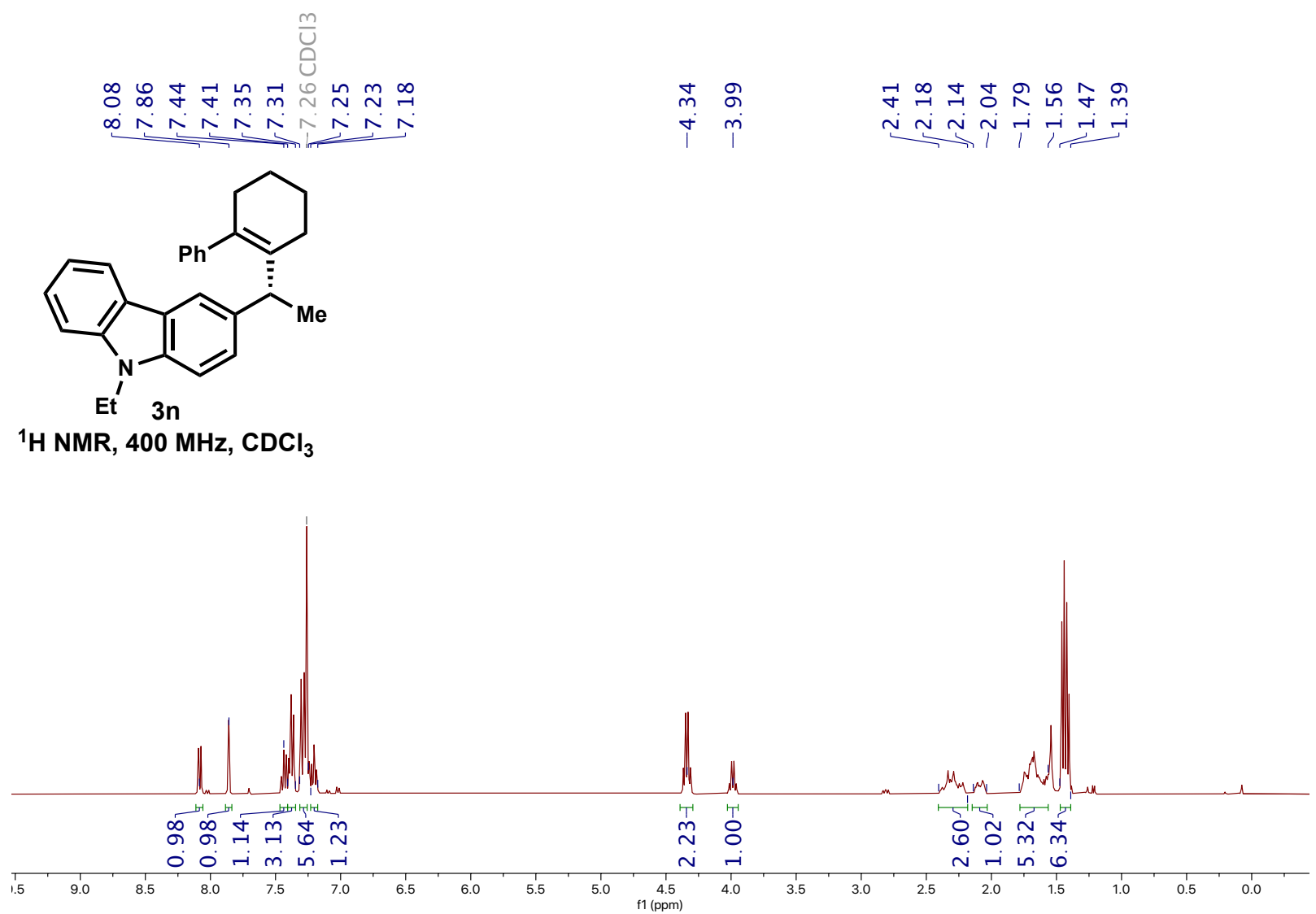

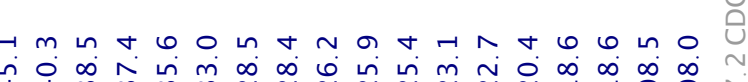

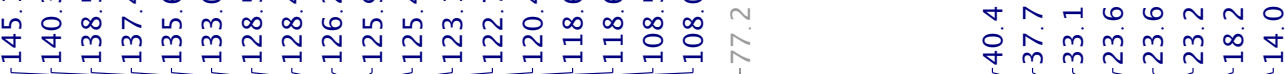<smiles>CCn1c2ccccc2c2cc(C(C3=C(c4ccccc4)CCCC3)C3CCCCC3)ccc21</smiles>

${ }^{13} \mathrm{C}$ NMR, $101 \mathrm{MHz}, \mathrm{CDCl}_{3}$
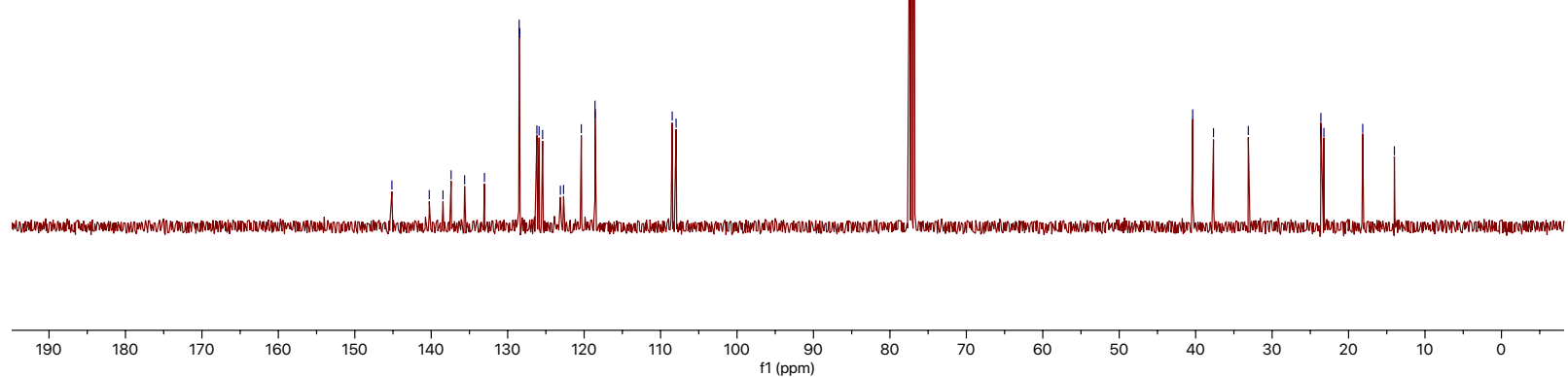
Supporting Information

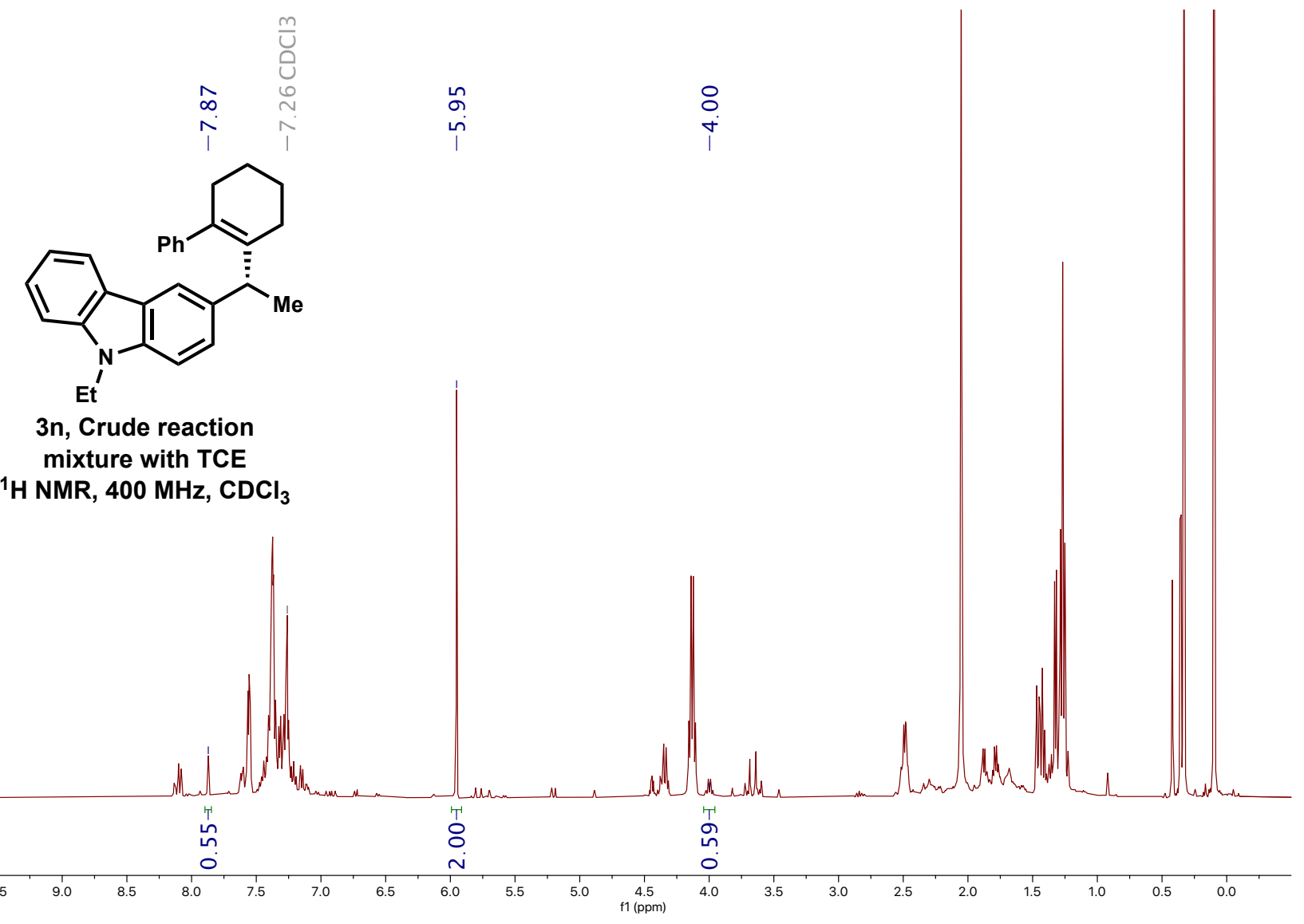


Supporting Information

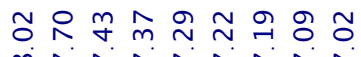

$\infty N \hat{N} N \hat{N}$<smiles>CCn1c2ccccc2c2cc(CCC3=C(c4ccccc4)CCCC3)ccc21</smiles>

${ }^{1} \mathrm{H}$ NMR, $500 \mathrm{MHz}^{\mathrm{CDCl}_{3}}$

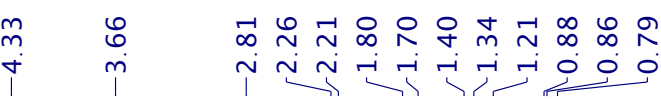

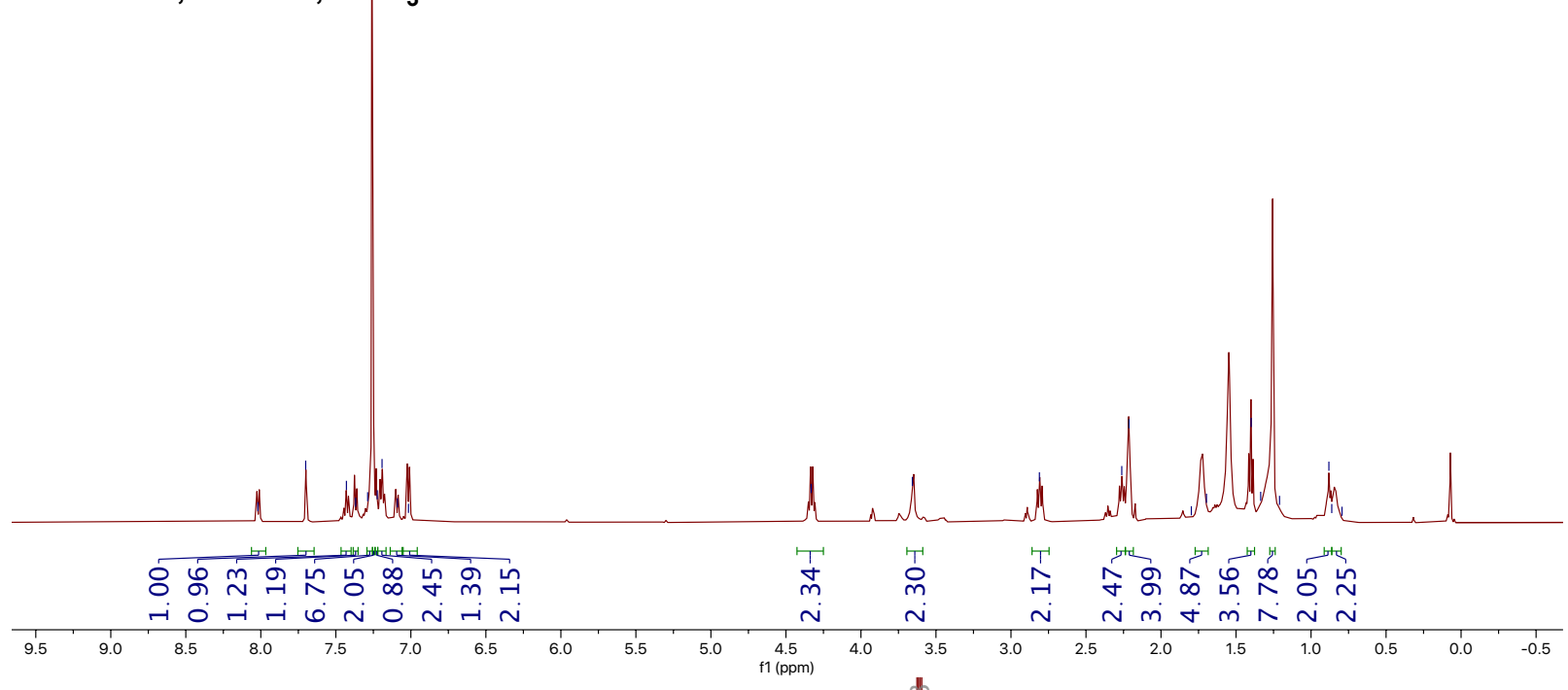

$\wedge 6 \wedge+-1$ L 0 L

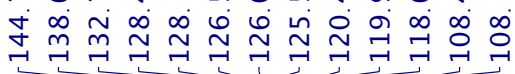

$6+06 \infty \sim 6 \mathrm{~m} \sigma$ $\hat{m} \hat{m} \stackrel{\sim}{m} \underset{m}{\sim} \stackrel{\sim}{\sim} \underset{\sim}{\sim}$<smiles>CCn1c2ccccc2c2cc(CCC3=C(c4ccccc4)CCCC3)ccc21</smiles>

${ }^{13} \mathrm{C}$ NMR, $126 \mathrm{MHz}, \mathrm{CDCl}_{3}$
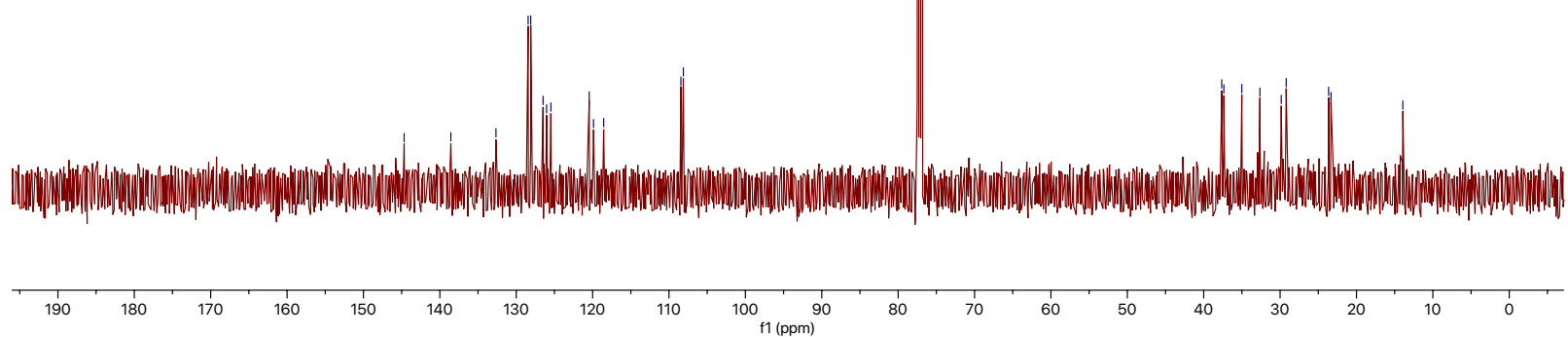
Supporting Information

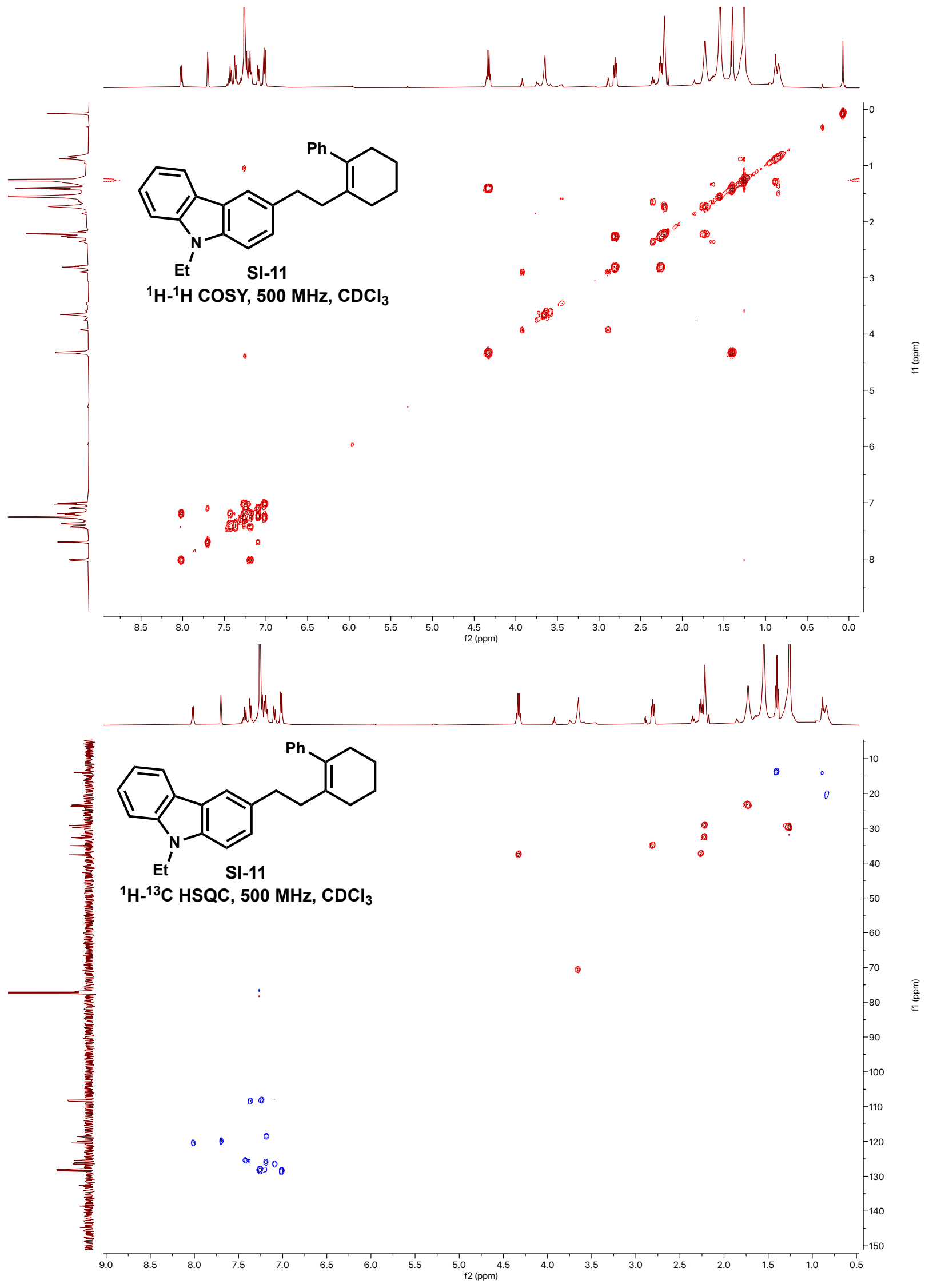


Supporting Information

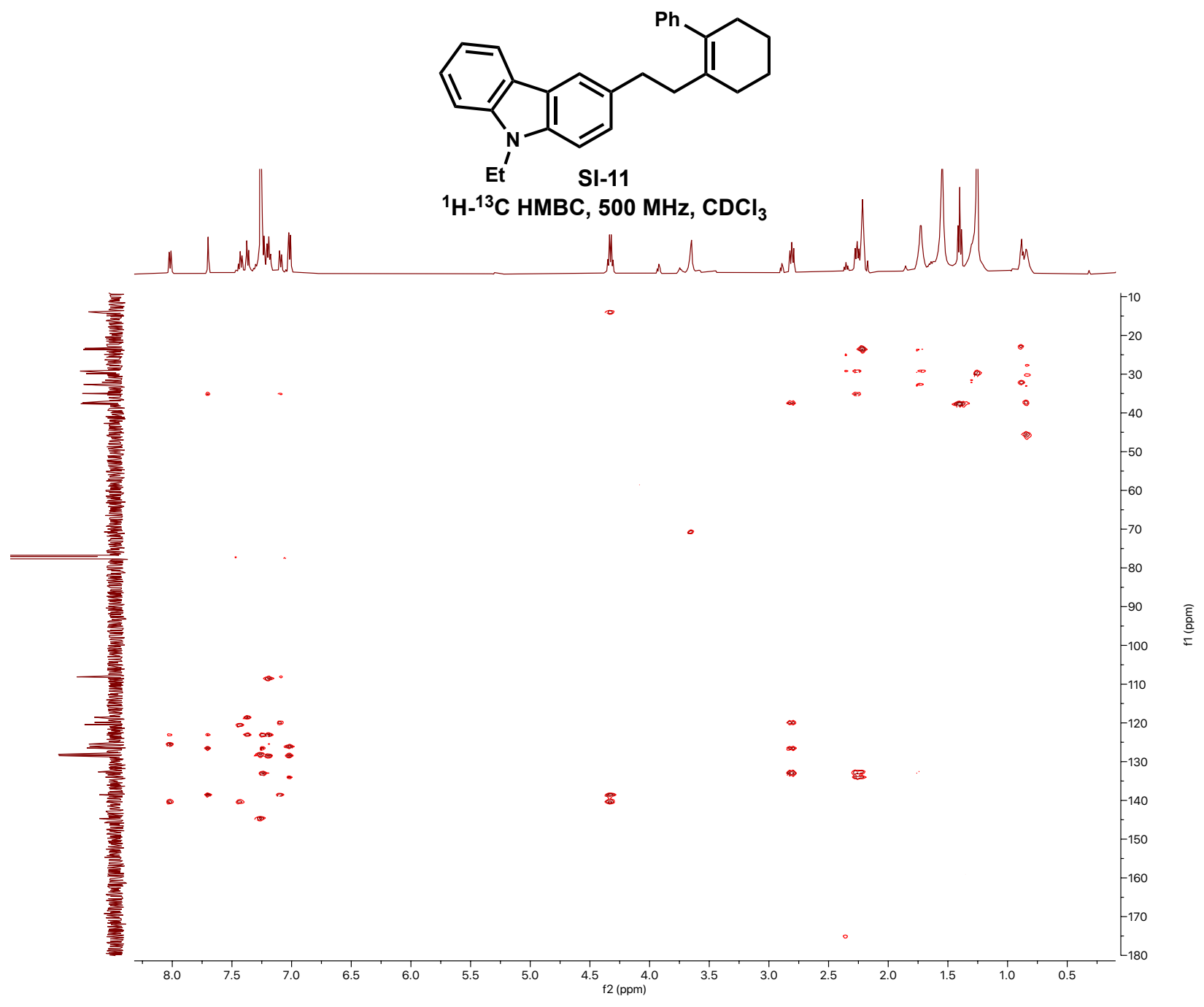


Supporting Information

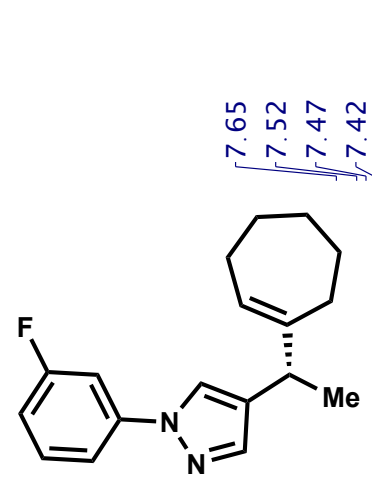

30

${ }^{1} \mathrm{H}$ NMR, $400 \mathrm{MHz}, \mathrm{CDCl}_{3}$
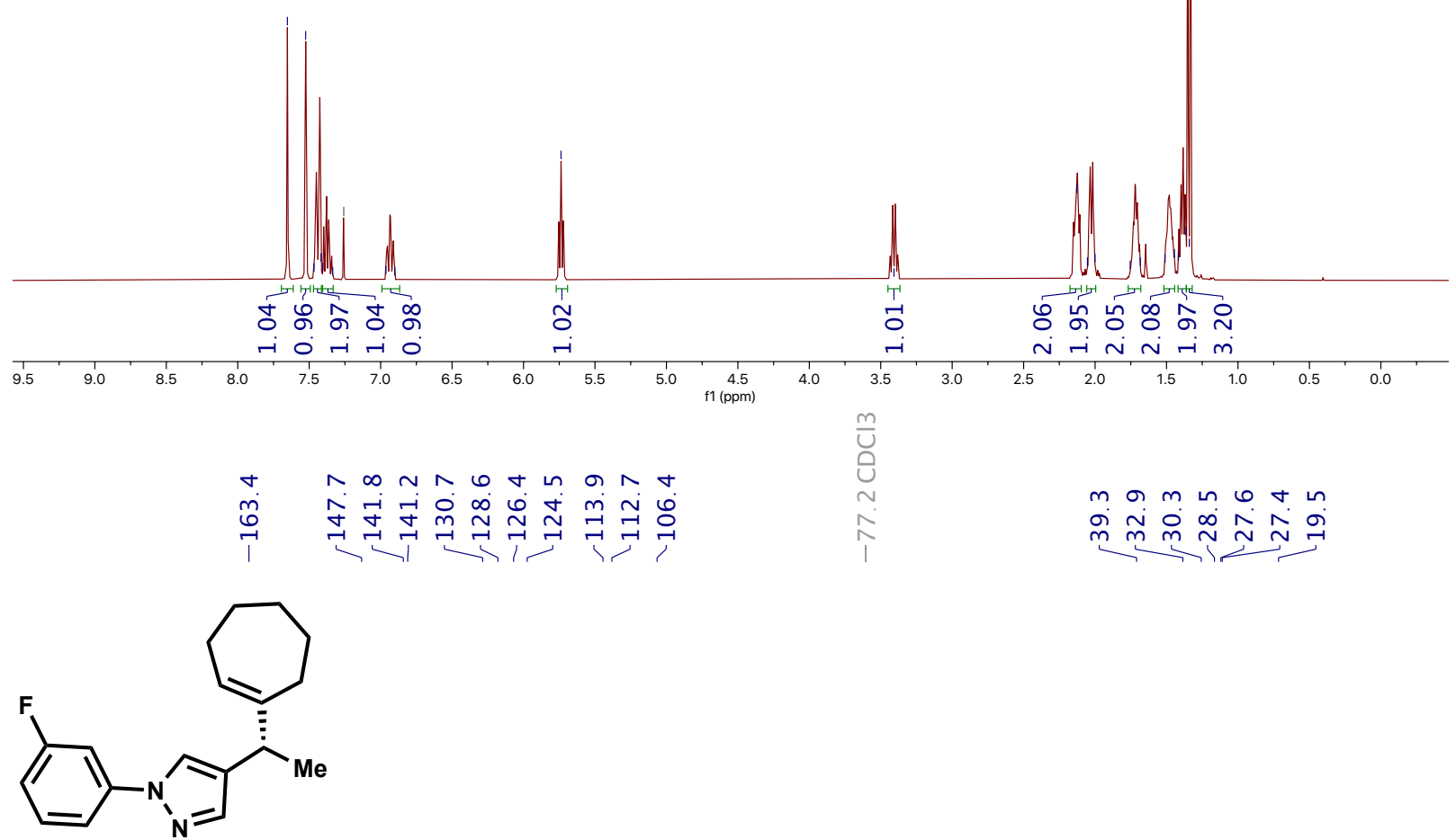

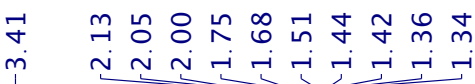

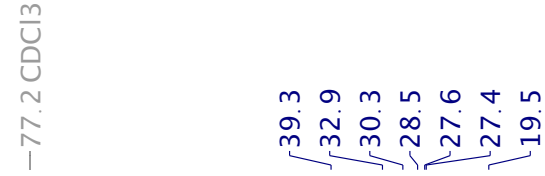

30

${ }^{13} \mathrm{C}$ NMR, $101 \mathrm{MHz}, \mathrm{CDCl}_{3}$
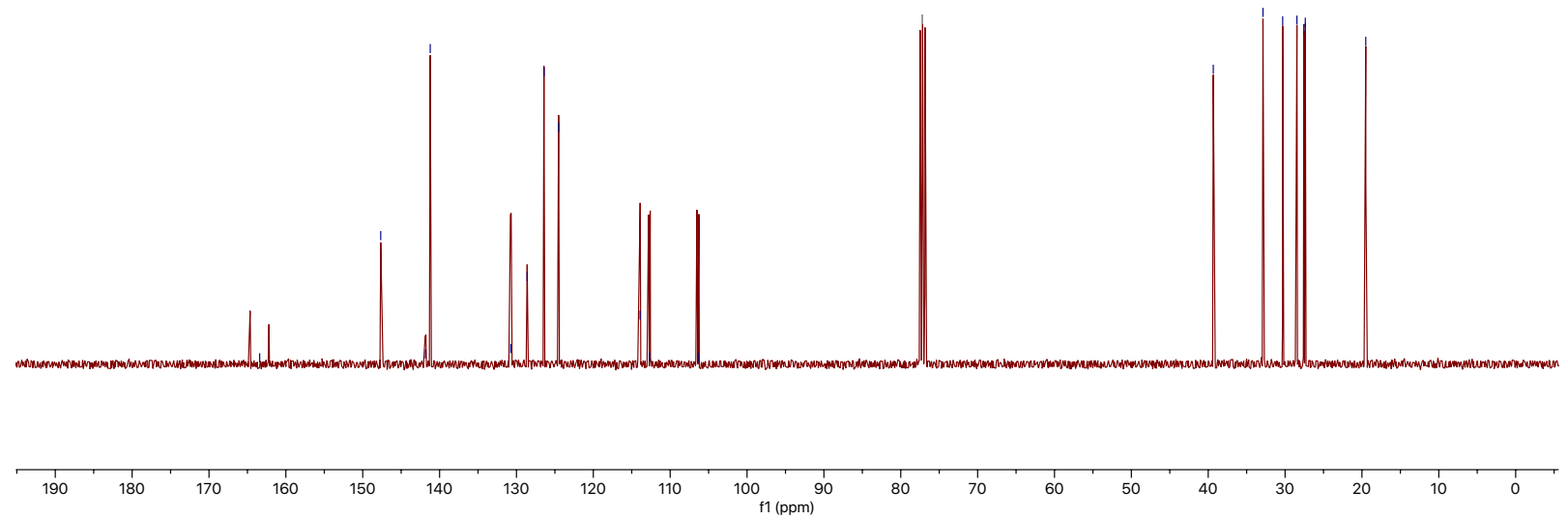
Supporting Information

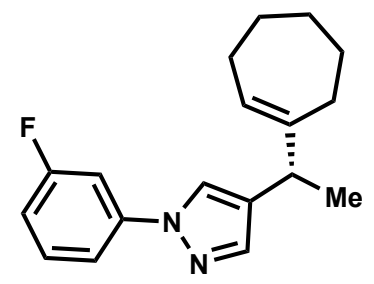

ㄱ
감
!

${ }^{19} \mathrm{~F} \mathrm{NMR,}, 376 \mathrm{MHz}, \mathrm{CDCl}_{3}$

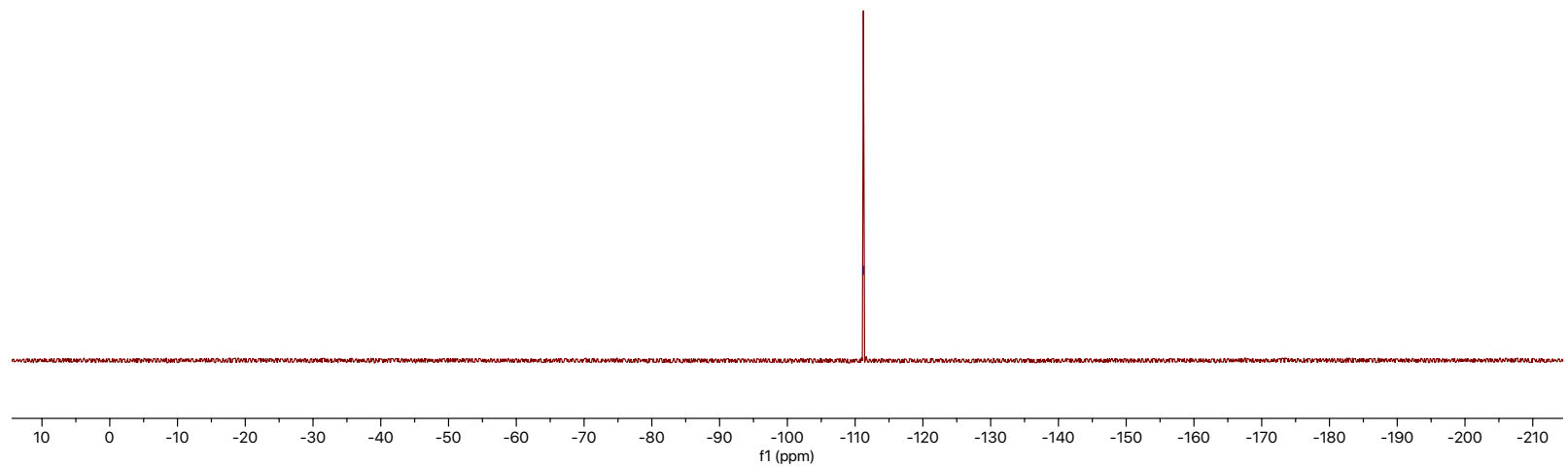


Supporting Information
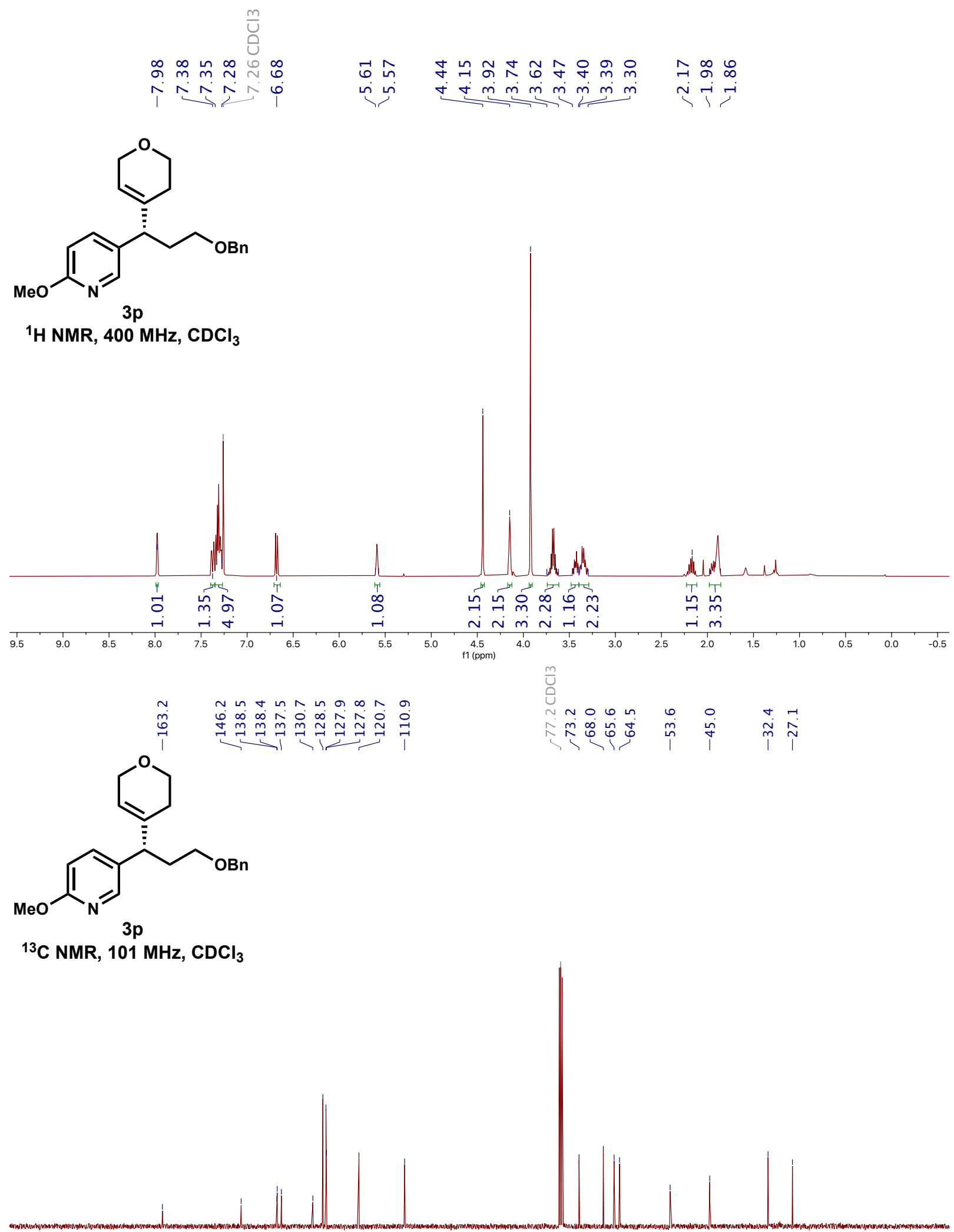

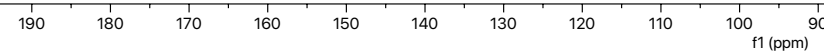


Supporting Information
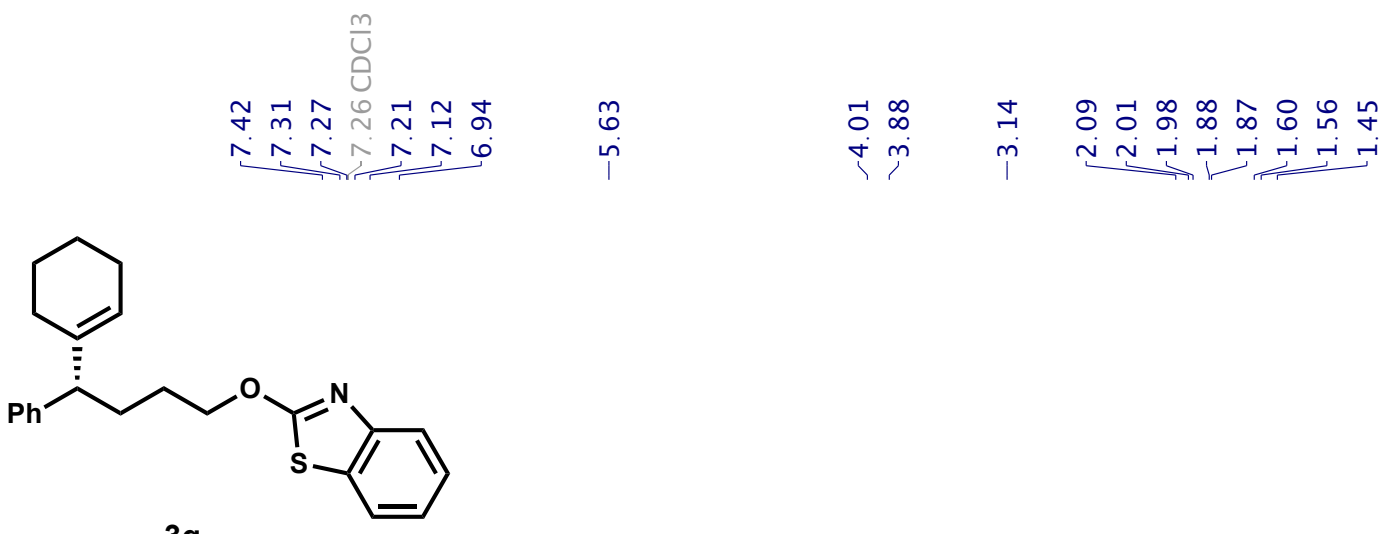

${ }^{1} \mathrm{H}$ NMR, $400 \mathrm{MHz}, \mathrm{CDCl}_{3}$

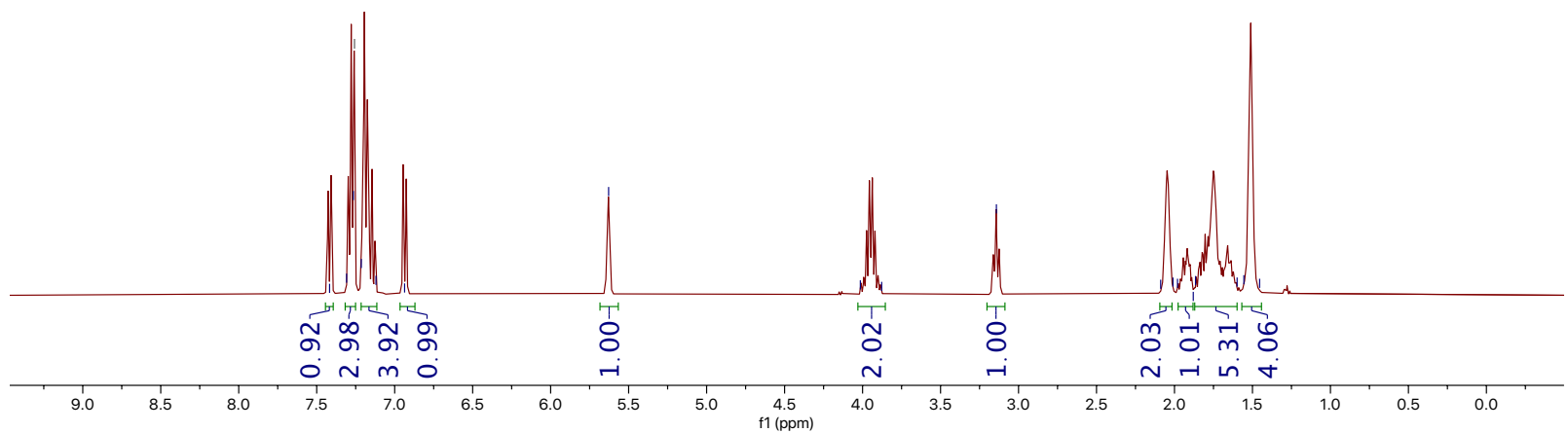

$a \infty \wedge \sim m a m \sim 0$ a $\infty$ O

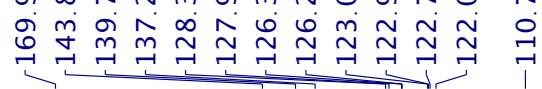

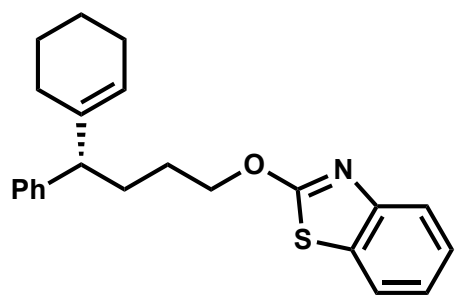

$3 q$

${ }^{13} \mathrm{C}$ NMR, $126 \mathrm{MHz}, \mathrm{CDCl}_{3}$

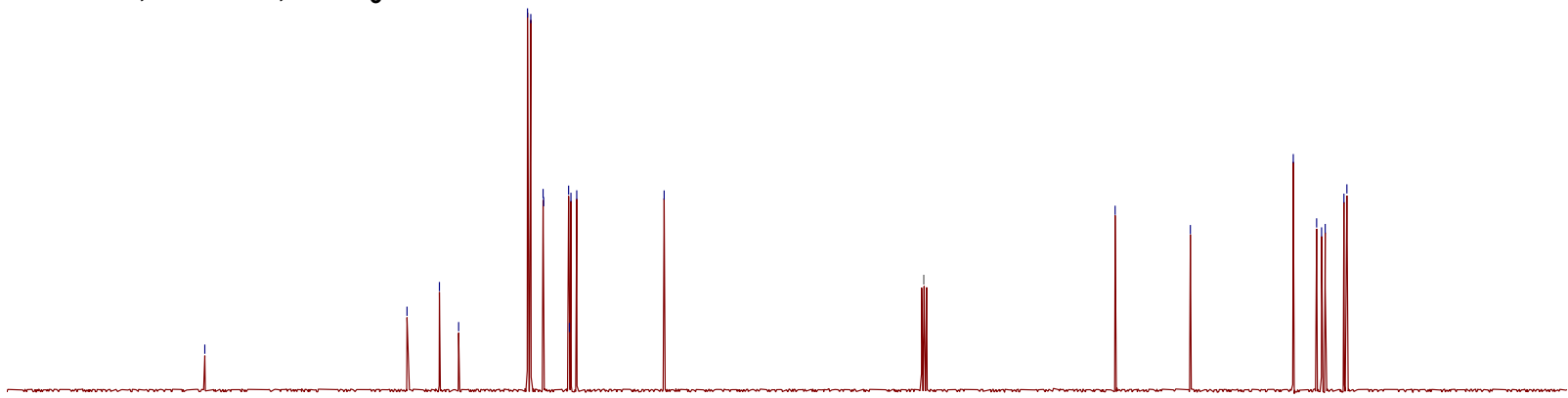

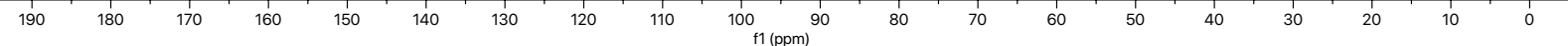


Supporting Information
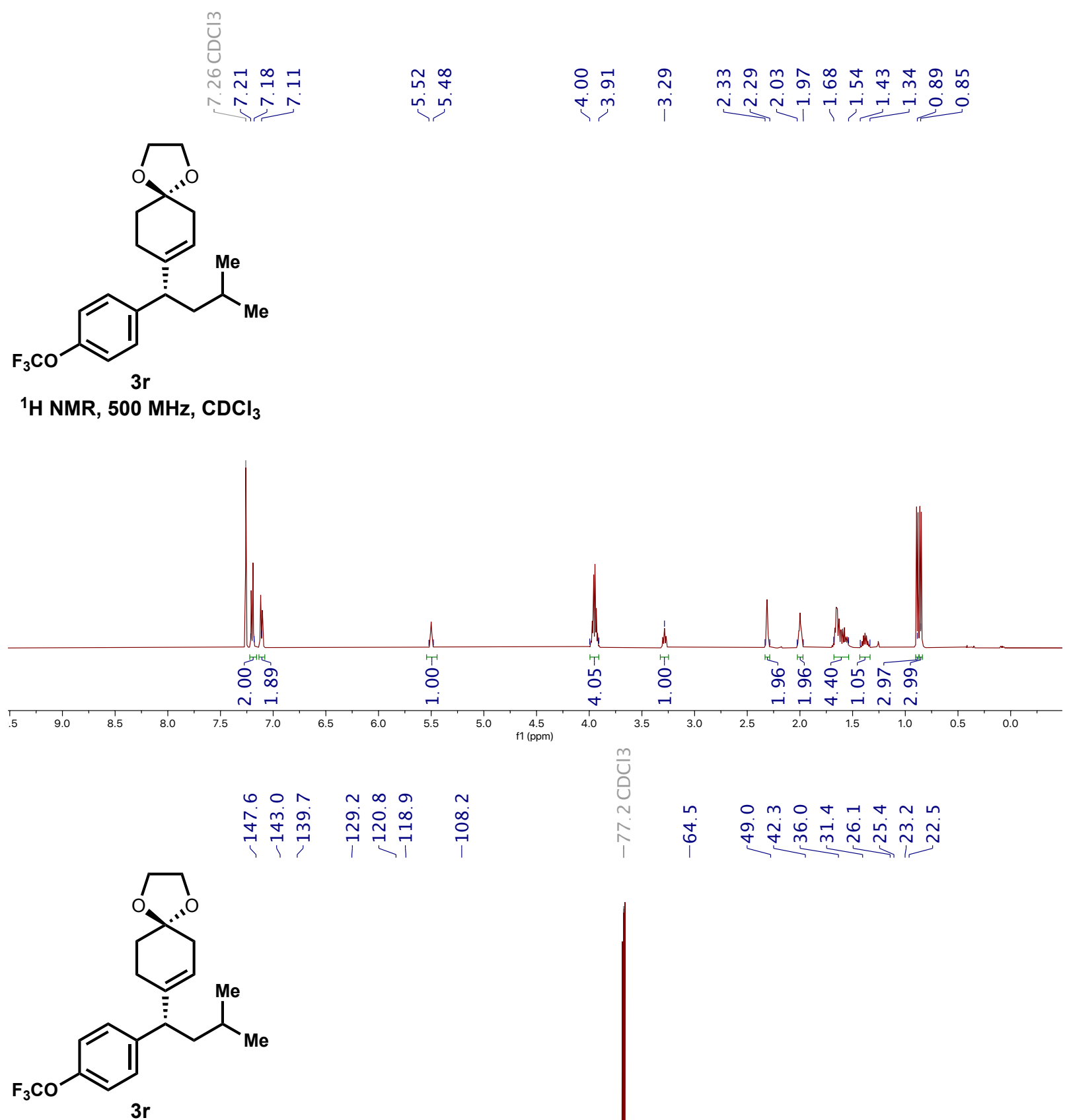

${ }^{13} \mathrm{C} \mathrm{NMR}, 126 \mathrm{MHz}, \mathrm{CDCl}_{3}$
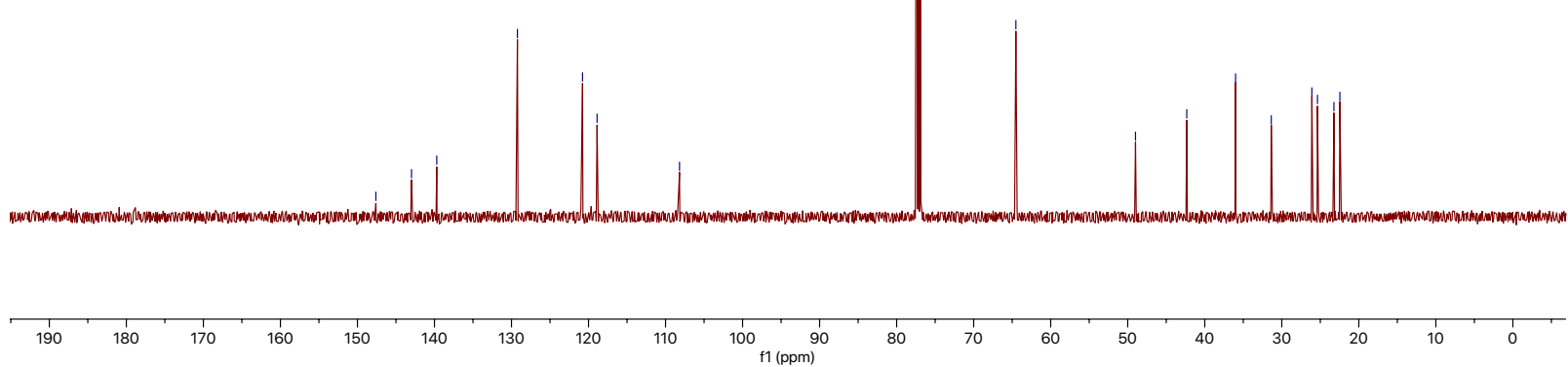
Supporting Information

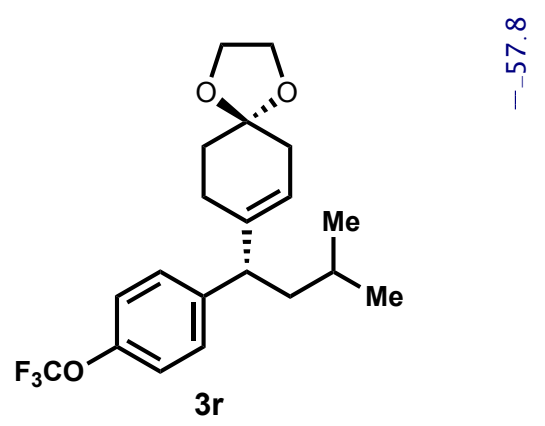

${ }^{19} \mathrm{~F}$ NMR, $471 \mathrm{MHz}^{\mathrm{CDCl}}{ }_{3}$

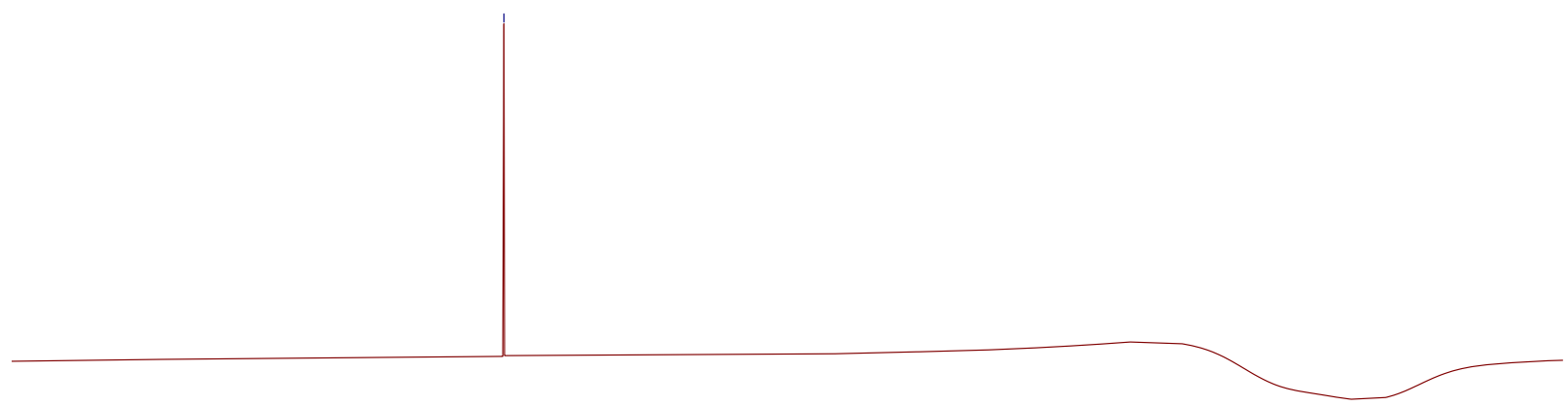

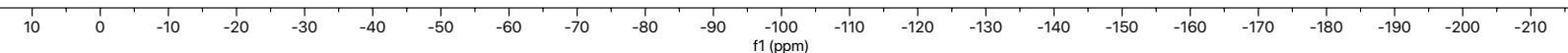



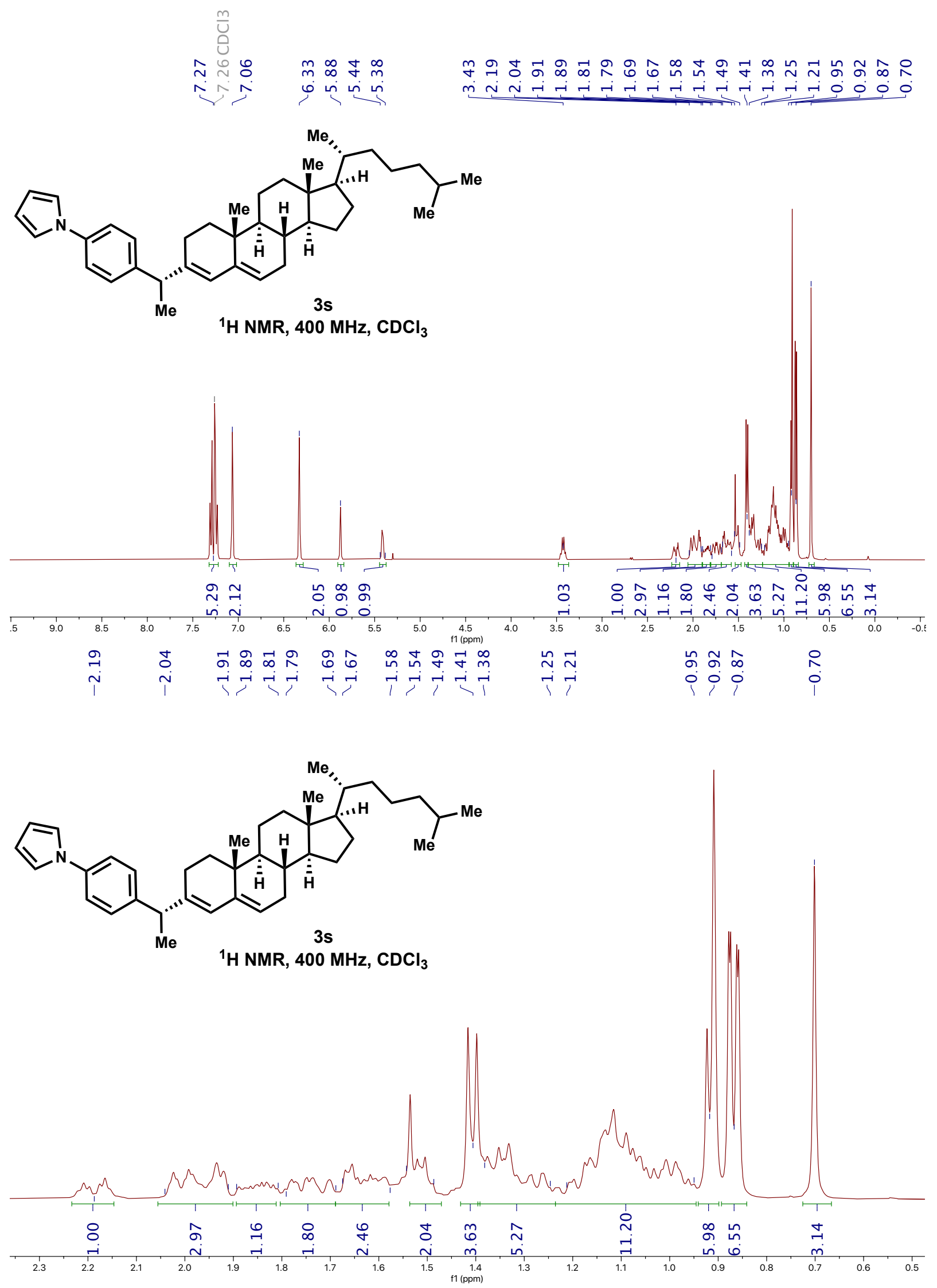


\section{Supporting Information}

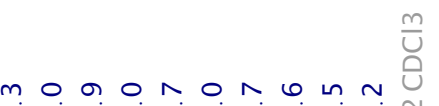

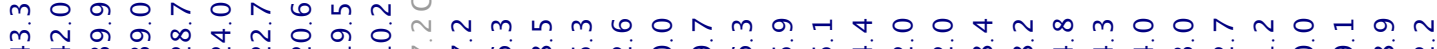

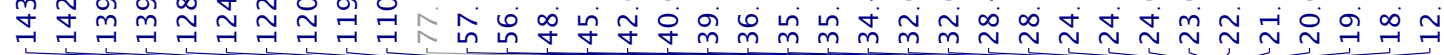
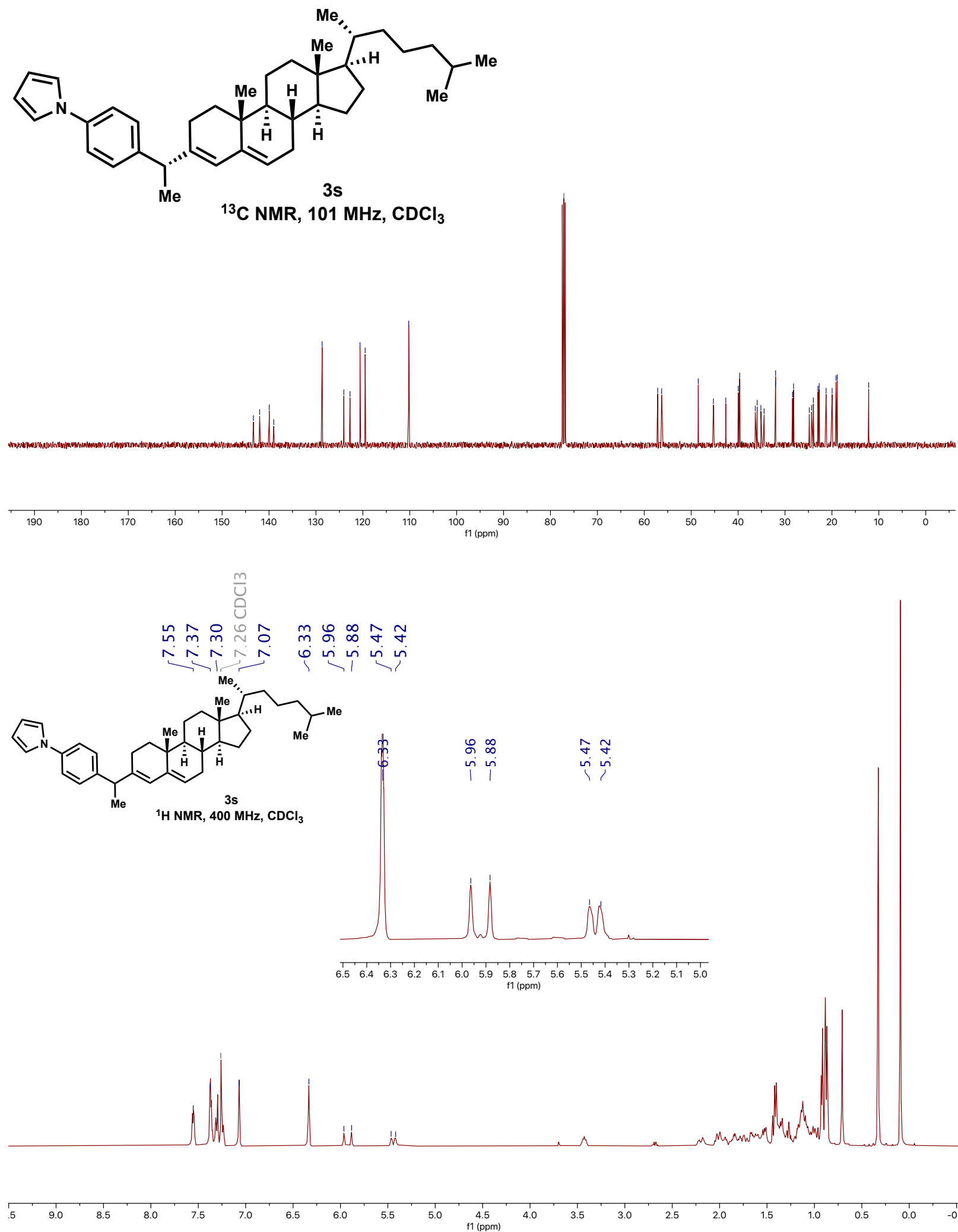
Supporting Information

$$
\begin{array}{ll}
n & \infty \\
& \infty \\
\text { nn } & \text { in }
\end{array}
$$

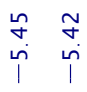
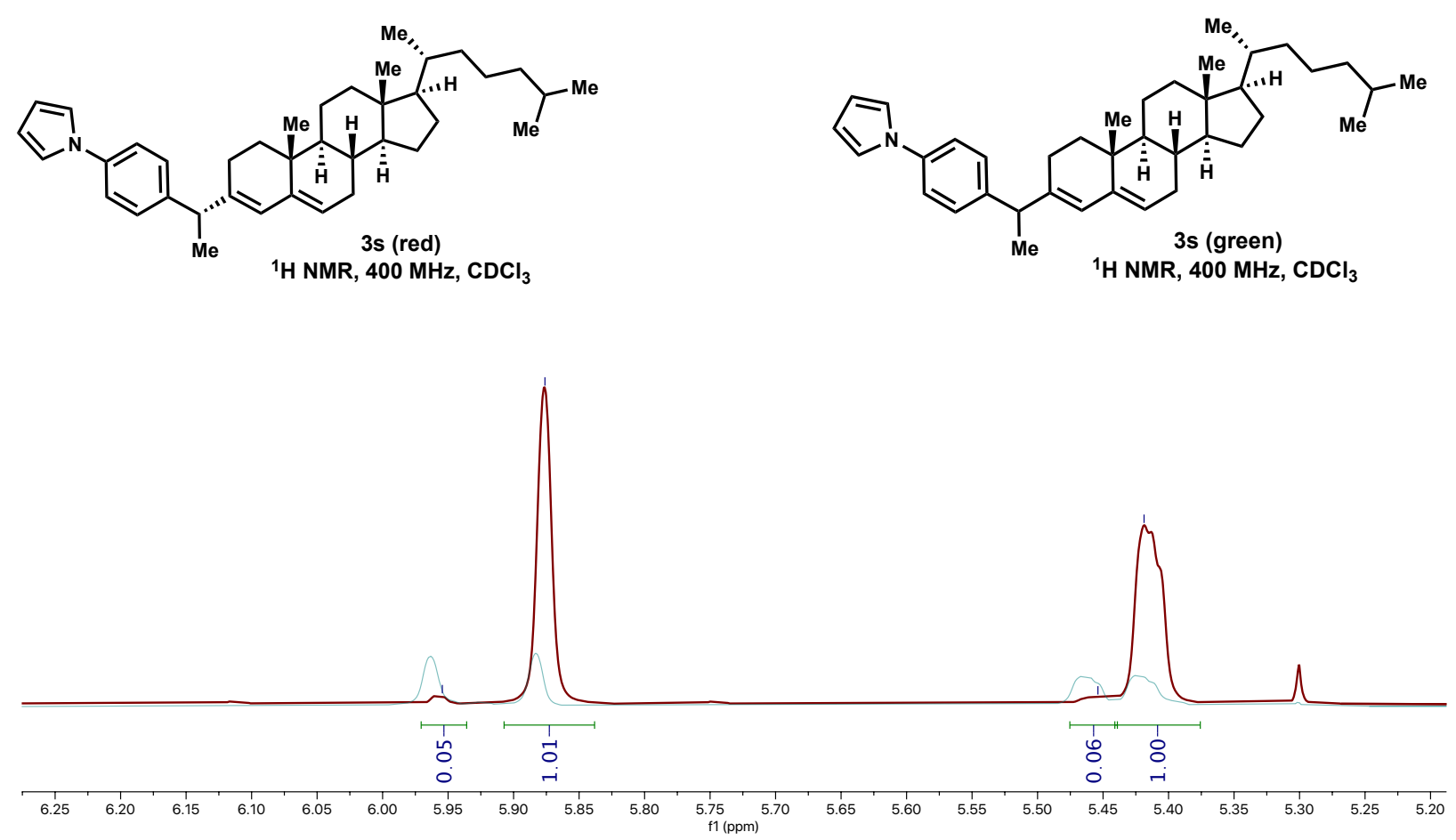
Supporting Information<smiles>CCOC(=O)N1CCC(=C2c3ccc(O)cc3CCc3cc(C(C)C)ccc32)CC1</smiles>

${ }^{1} \mathrm{H}$ NMR, $400 \mathrm{MHz}, \mathrm{CDCl}_{3}$

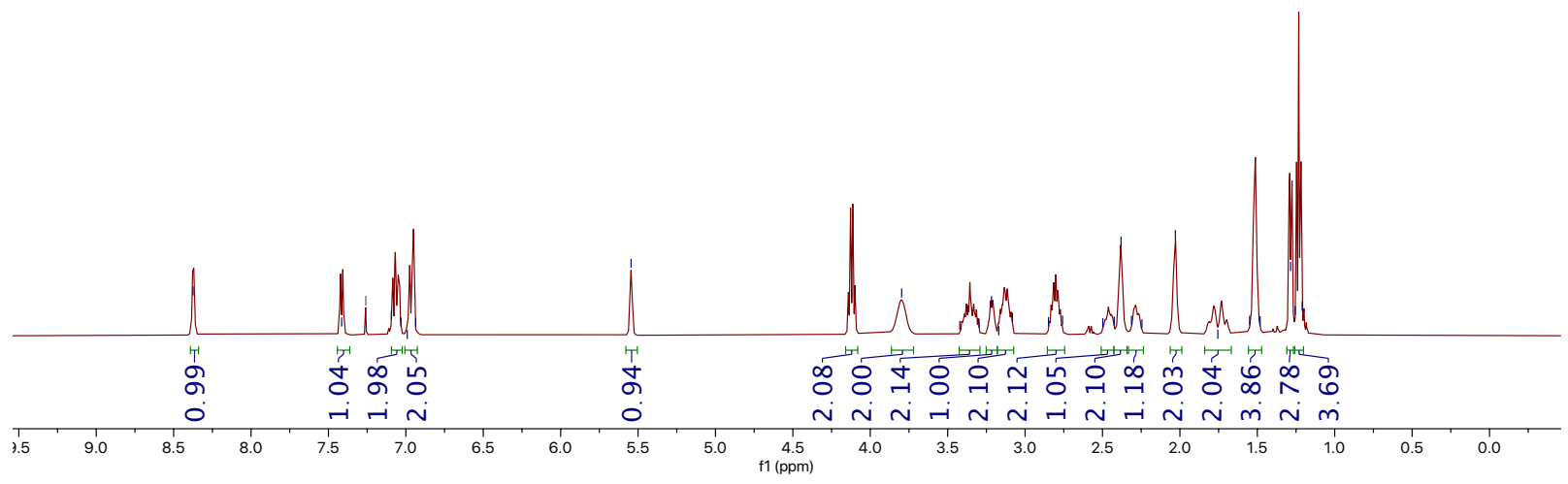

$\sim 60-1 \sim m m$ in $0 m+\sim r \infty$ 少

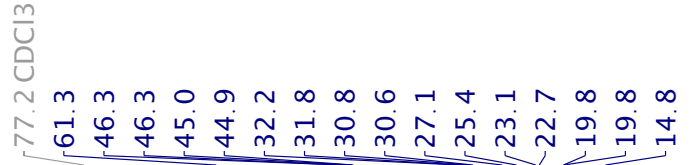<smiles>CCOC(=O)N1CCC(=C2c3ccc([C@@H](C)C4=CCCCC4)cc3CCc3cccnc32)CC1</smiles>

${ }^{13} \mathrm{C} \mathrm{NMR}, 101 \mathrm{MHz}, \mathrm{CDCl}_{3}$
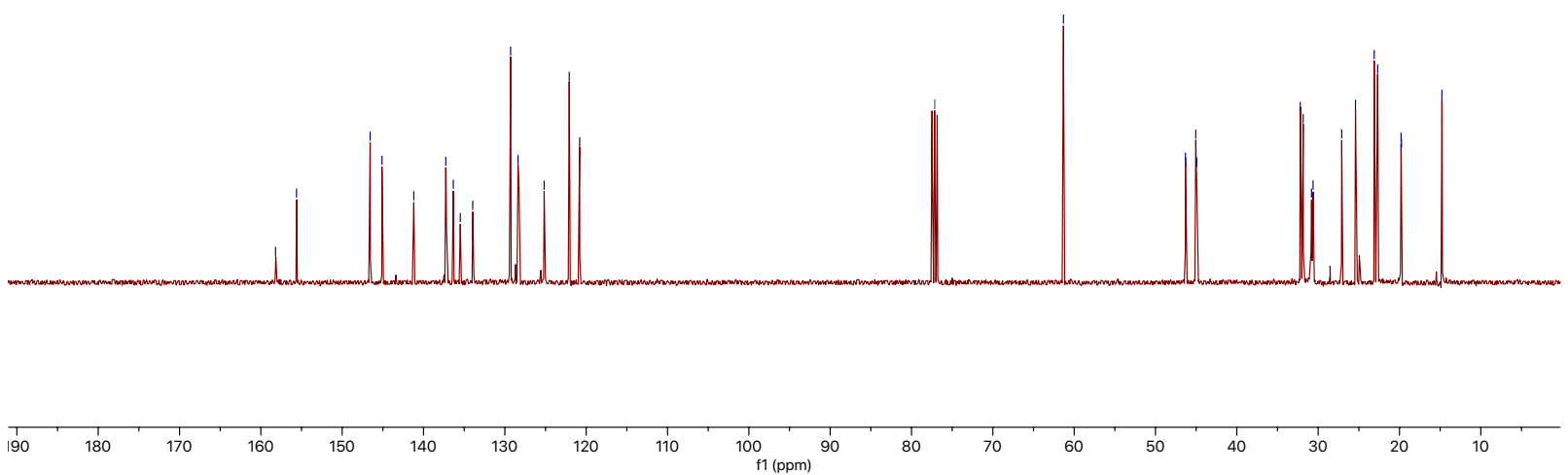
Supporting Information

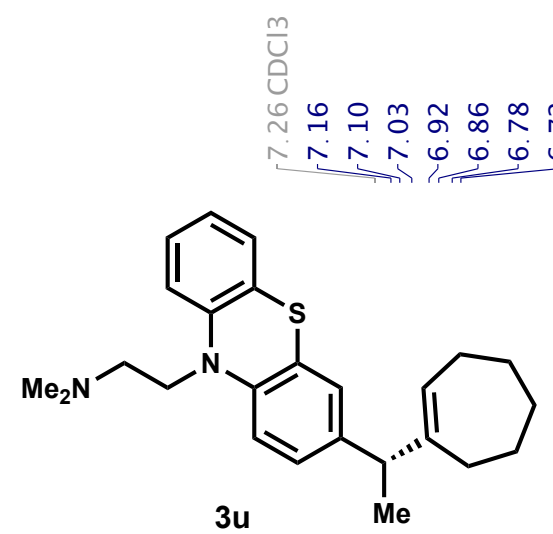

${ }^{1} \mathrm{H}$ NMR, $400 \mathrm{MHz}^{\mathrm{CDCl}_{3}}$

이

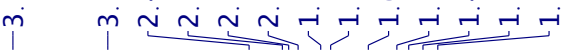
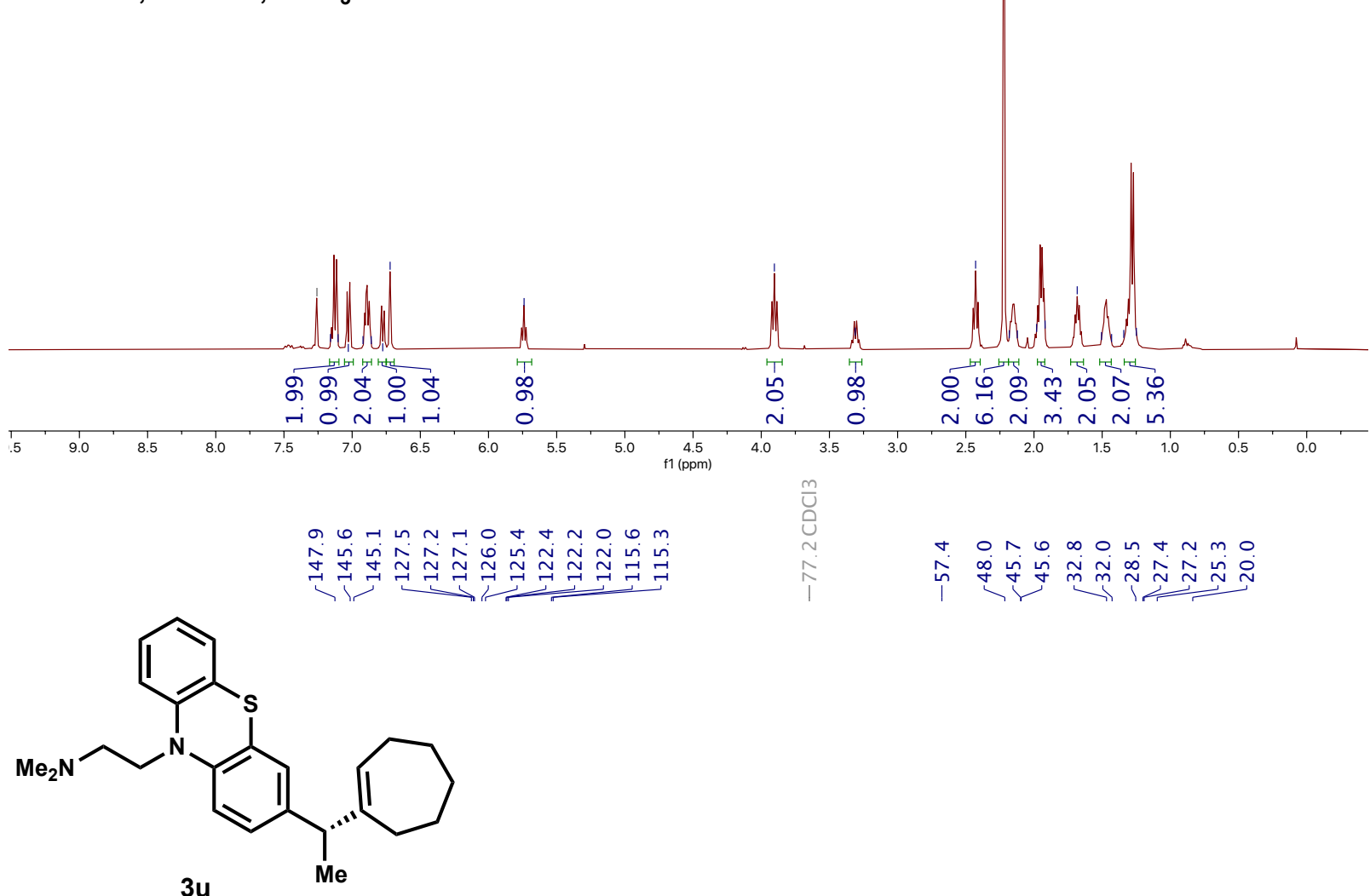

${ }^{13} \mathrm{C}$ NMR, $101 \mathrm{MHz}, \mathrm{CDCl}_{3}$
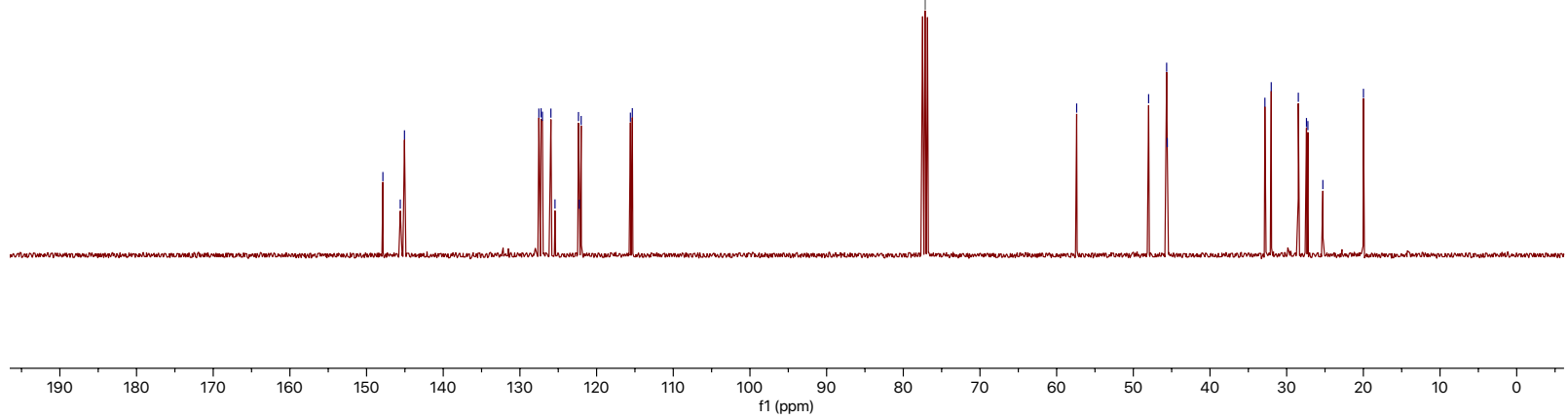
Supporting Information
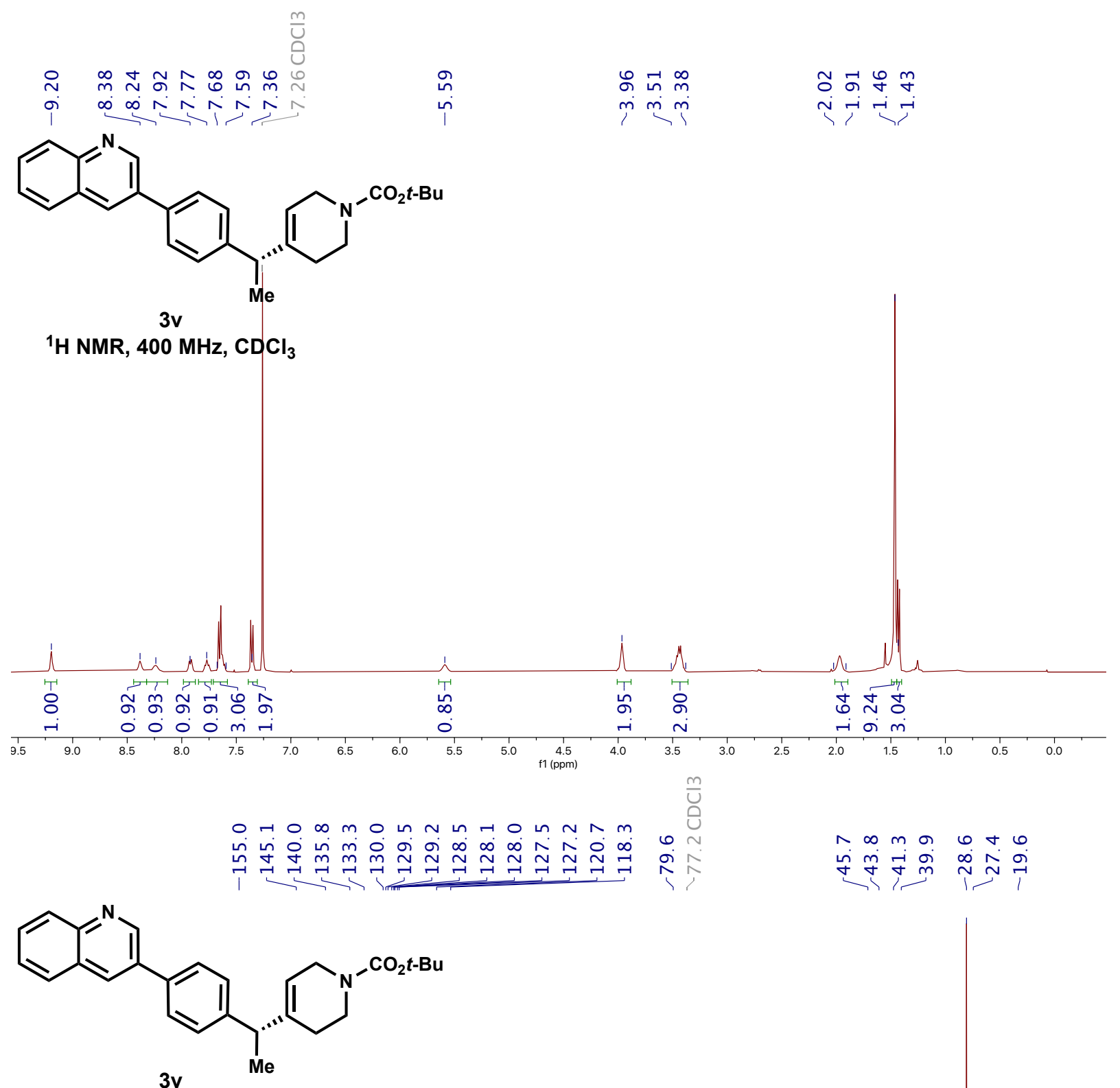

${ }^{13} \mathrm{C}$ NMR, $101 \mathrm{MHz}, \mathrm{CDCl}_{3}$

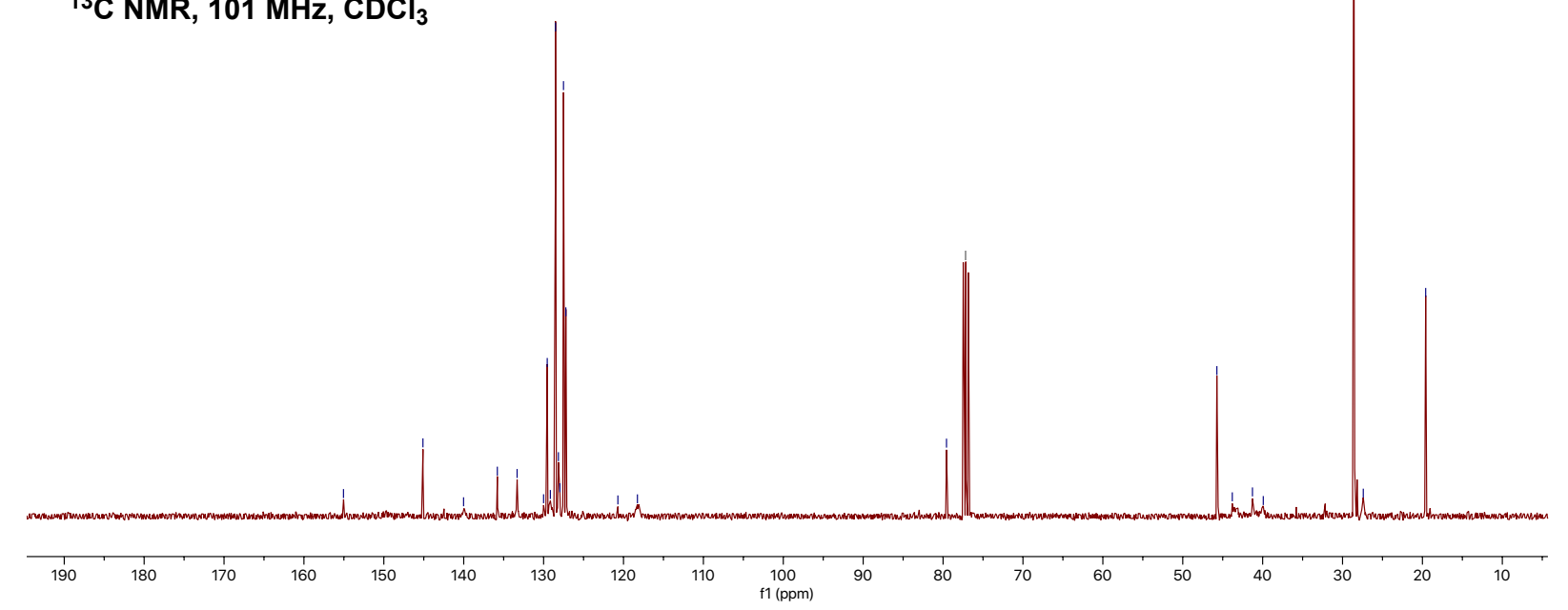


Supporting Information
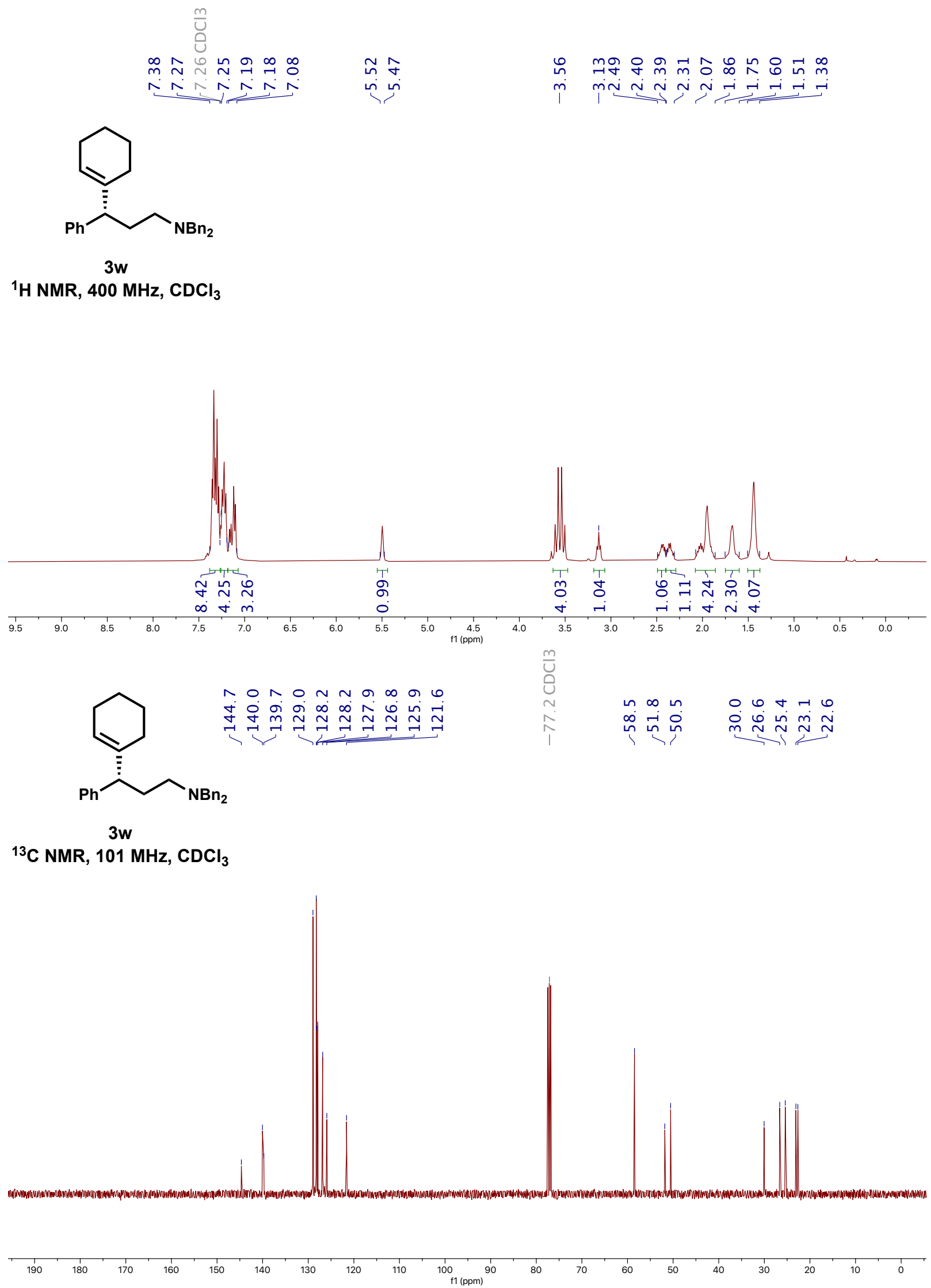
Supporting Information
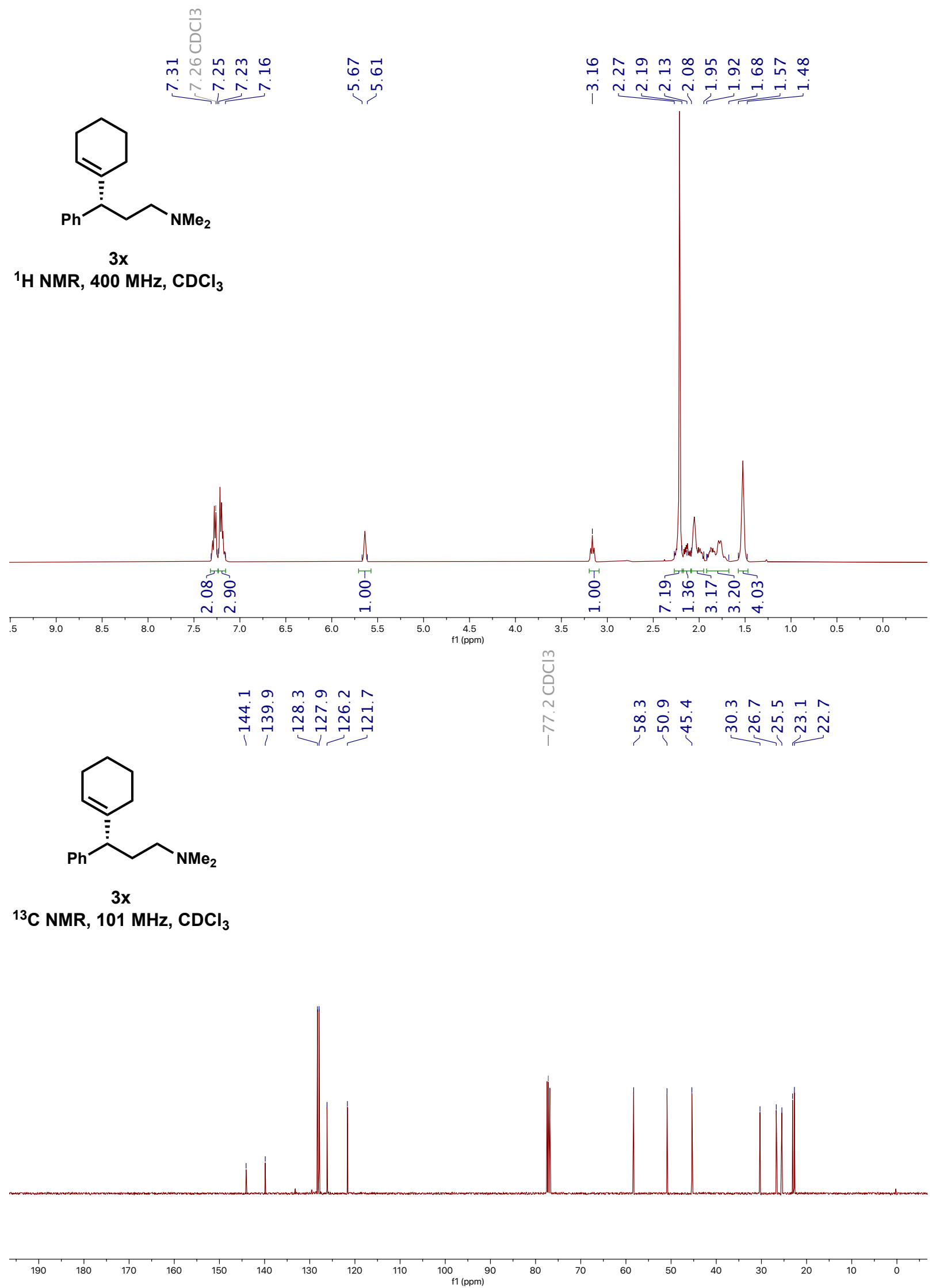
Supporting Information

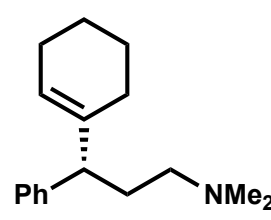

$3 x$, Crude reaction mixture with TCE ${ }^{1} \mathrm{H}$ NMR, $400 \mathrm{MHz} \mathrm{CDCl}_{3}$

๑ : :

थि

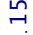

它
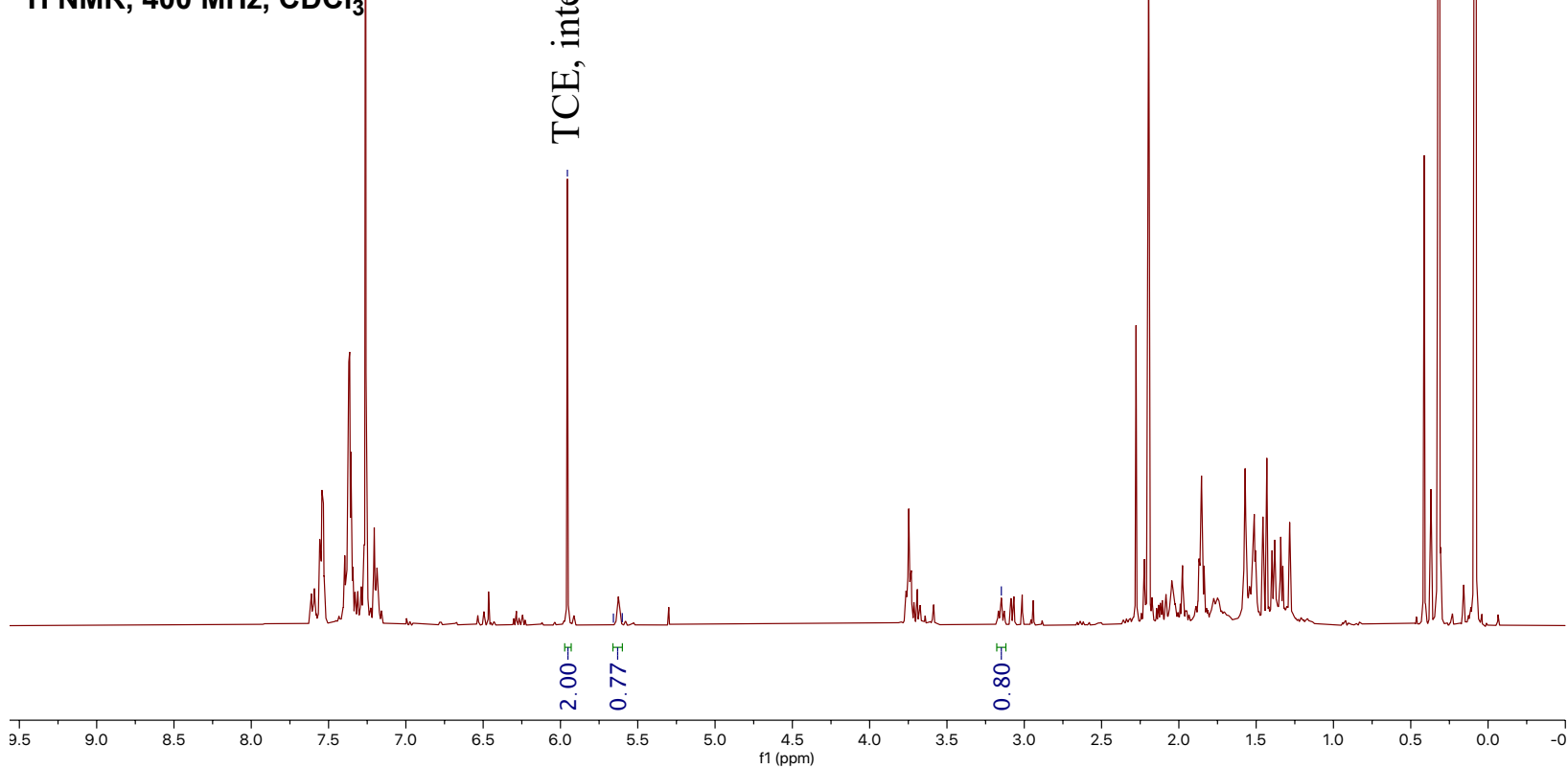
Supporting Information
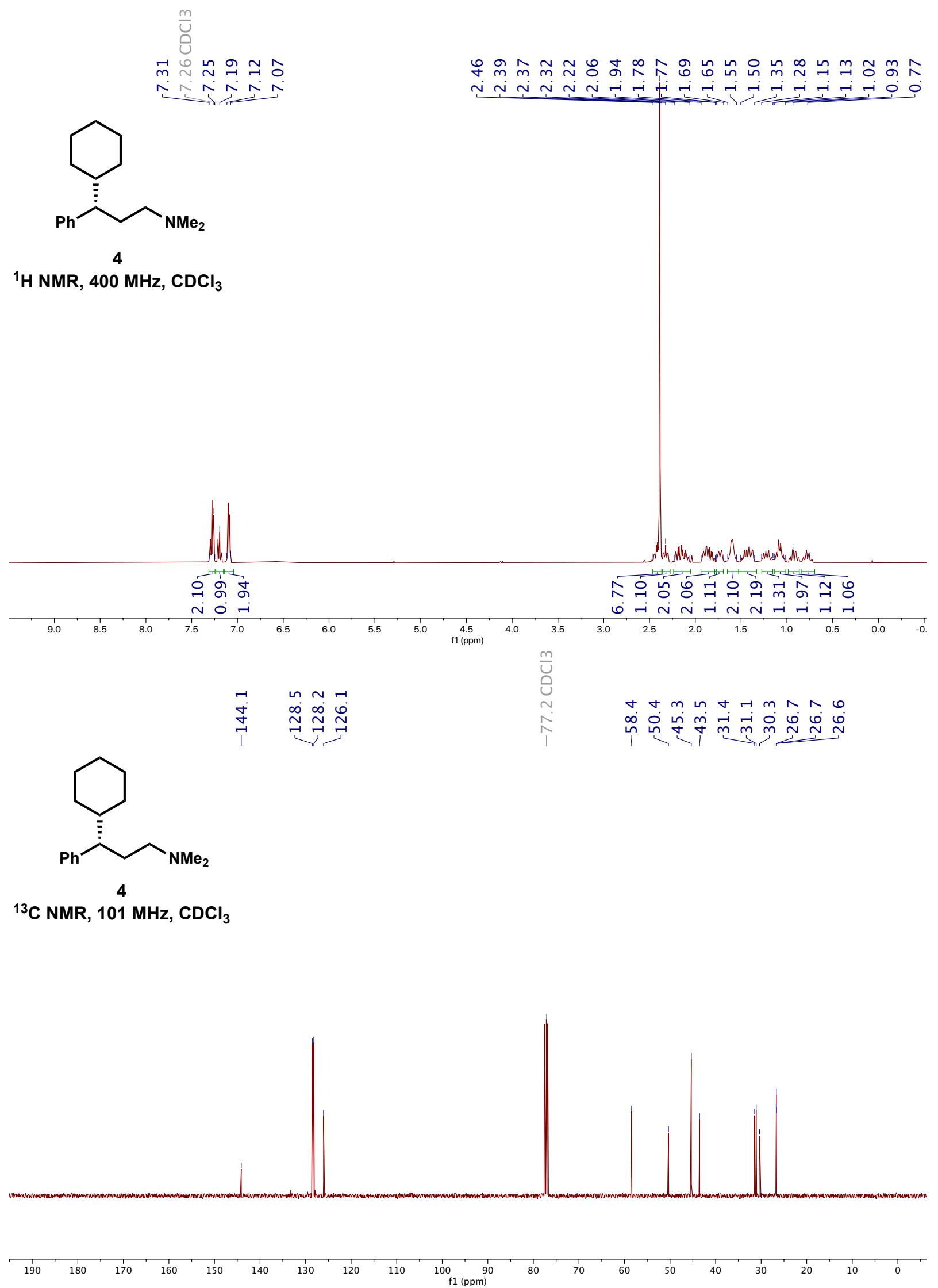
Supporting Information

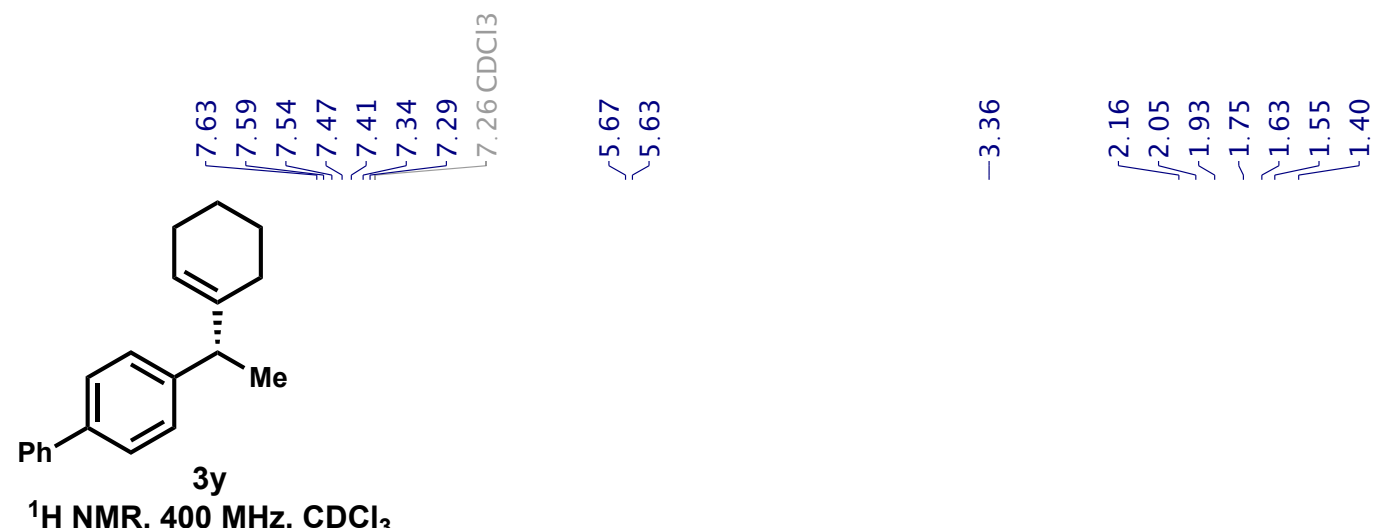



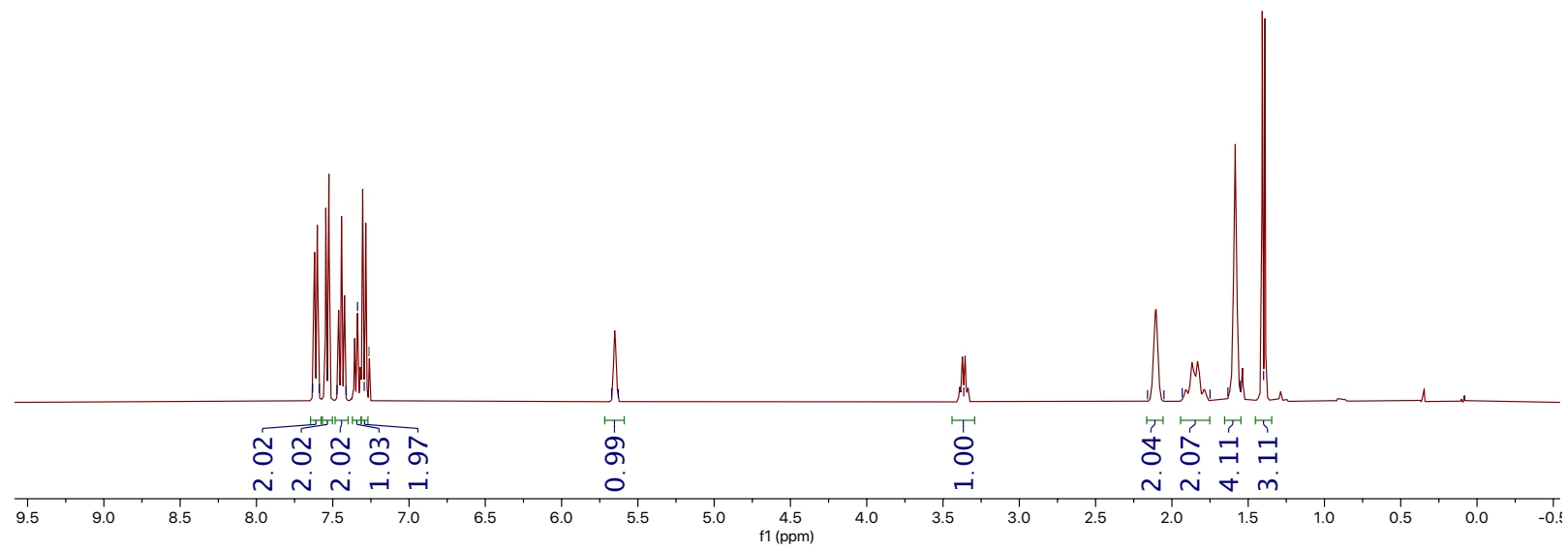

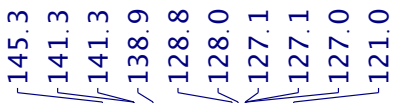

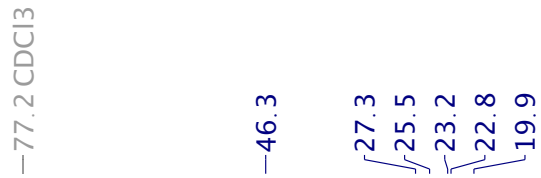<smiles>C[C@H](C1=CCCCC1)c1ccc(-c2ccccc2)cc1</smiles>

${ }^{13} \mathrm{C}$ NMR, $126 \mathrm{MHz}, \mathrm{CDCl}_{3}$
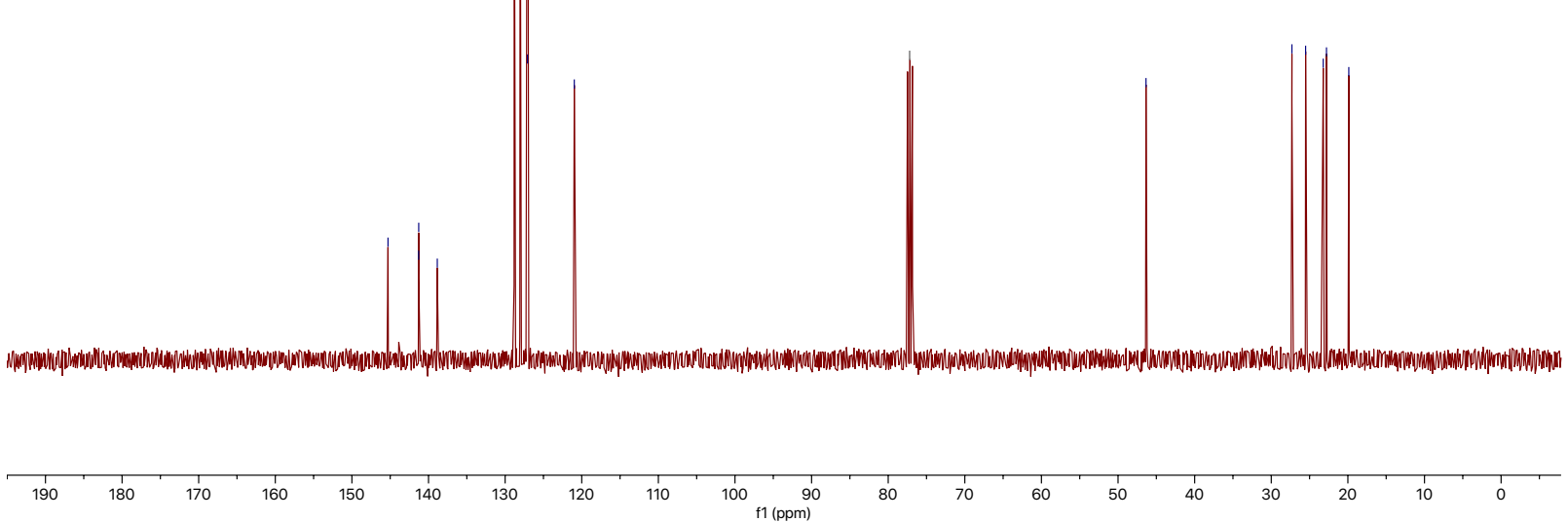
굼

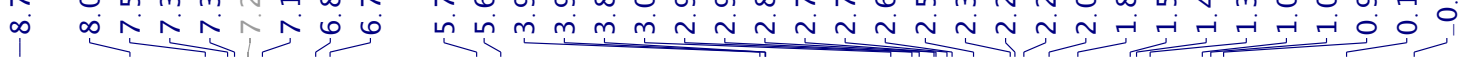

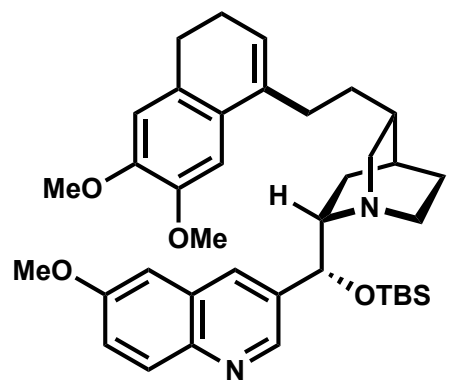

$6 a$

${ }^{1} \mathrm{H}$ NMR, $500 \mathrm{MHz}^{\mathrm{CDCl}_{3}}$
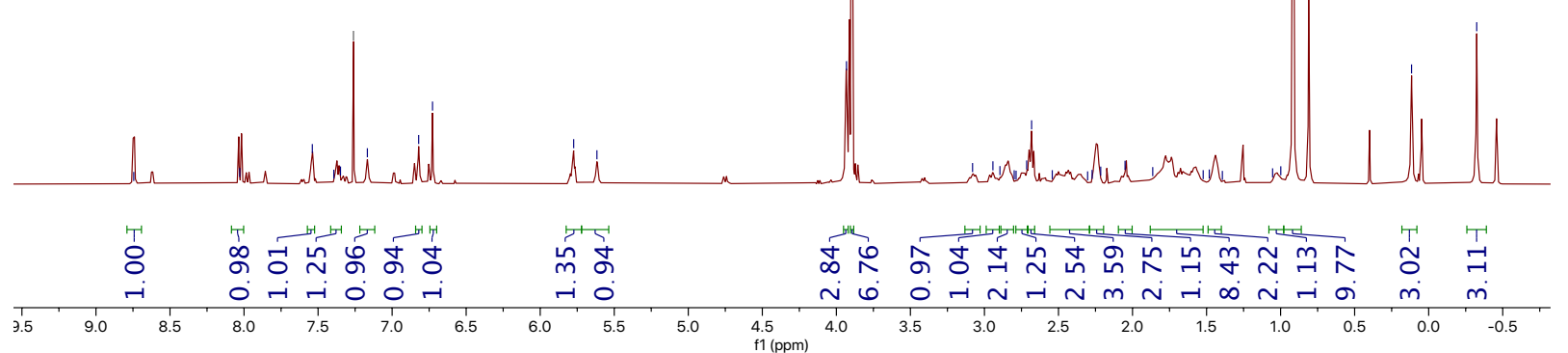

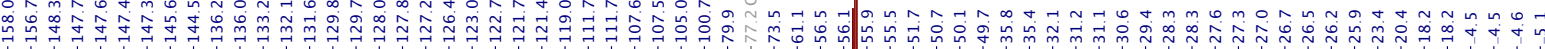

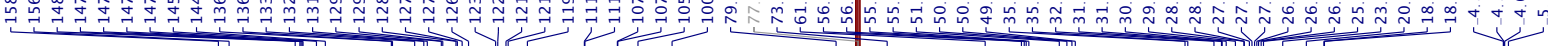

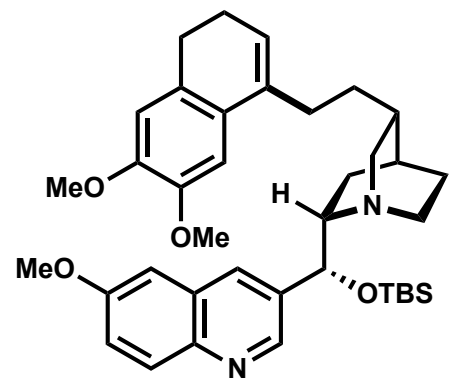

$6 a$

${ }^{13} \mathrm{C}$ NMR, $126 \mathrm{MHz}^{\mathrm{CDCl}_{3}}$

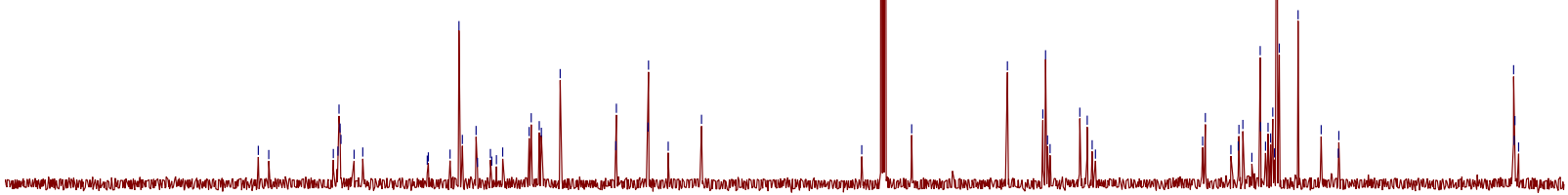

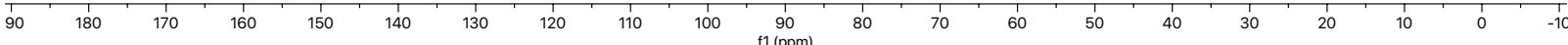


Supporting Information

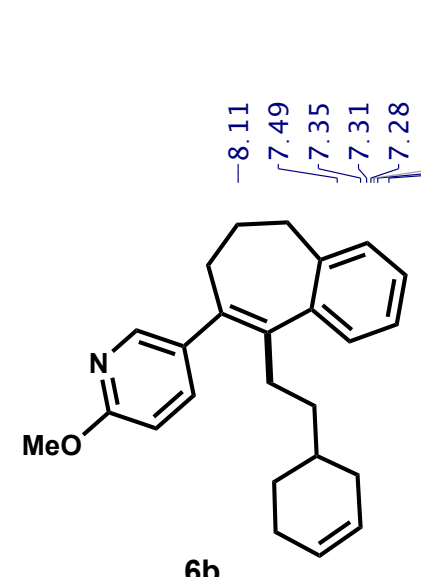

${ }^{1} \mathrm{H}$ NMR, $400 \mathrm{MHz} \mathrm{CDCl}_{3}$

Ч

^ヘ

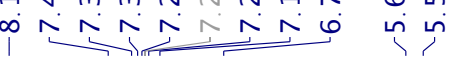

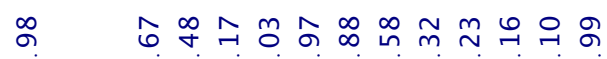

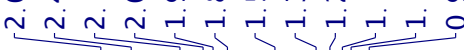

\section{H $400 \mathrm{MHz}, \mathrm{CDCl}_{3}$}

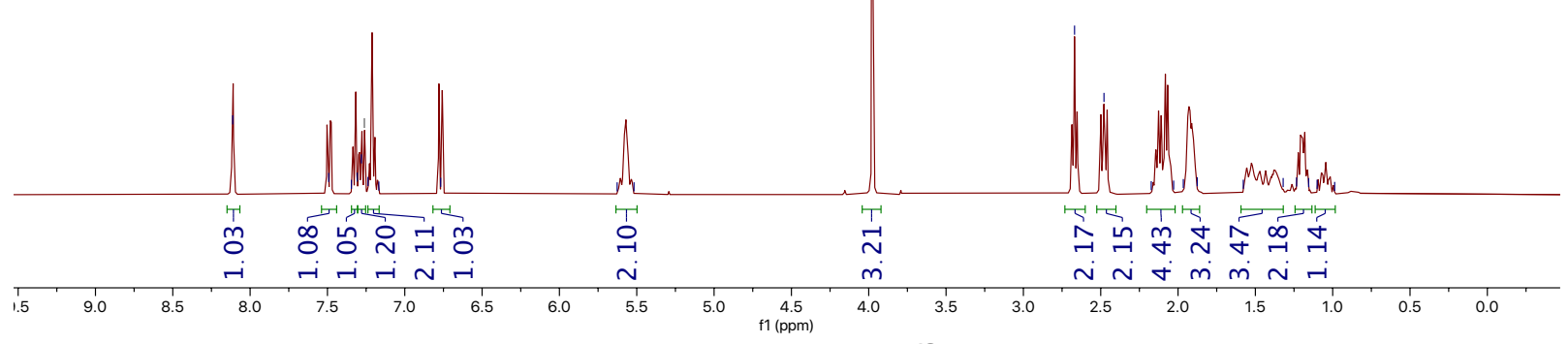

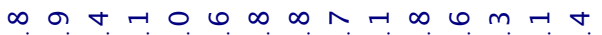

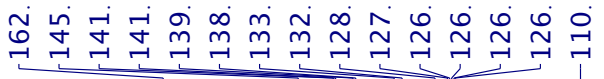<smiles>COc1ccc(C2=C(CCC3CC=CCC3)c3ccccc3CCC2)cn1</smiles>

${ }^{13} \mathrm{C}$ NMR, $101 \mathrm{Mhz}, \mathrm{CDCl}_{3}$

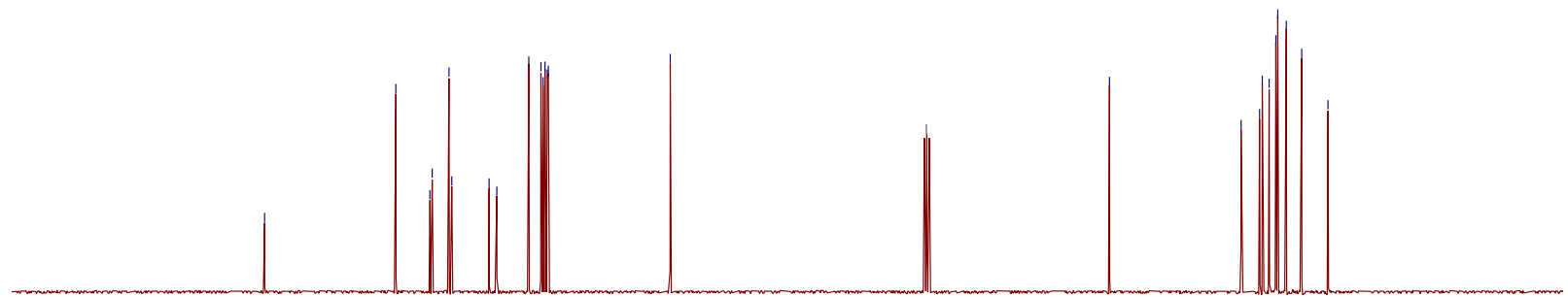

\begin{tabular}{lllllllllllllllll}
\hline 190 & 180 & 170 & 160 & 150 & 140 & 130 & 120 & 110 & 100 & 10 & 1 \\
$\mathrm{f} 1(\mathrm{ppm})$ & 10 & 80 & 70 & 60 & 50 & 40 & 30 & 20 & 10 & 0
\end{tabular}


Supporting Information
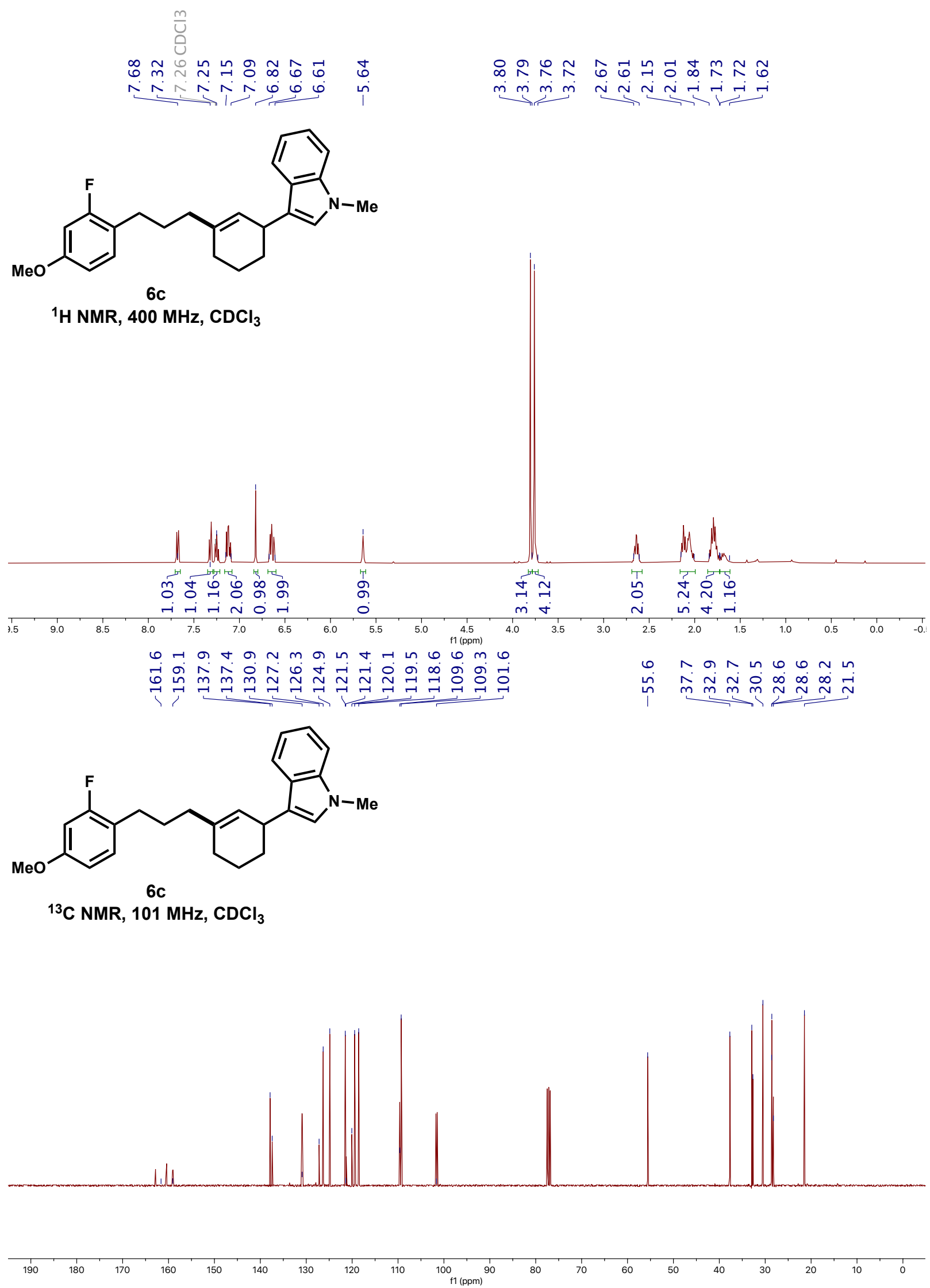
Supporting Information

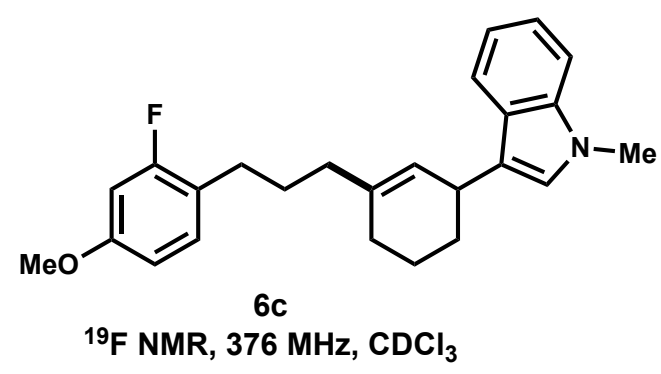

$\infty$
0
0
$\cdots$
+1
।

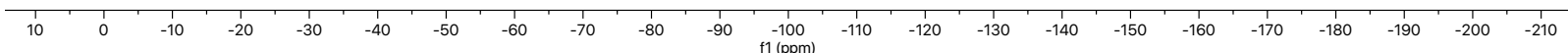


Supporting Information

$\stackrel{m}{u}$

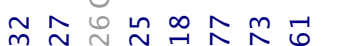

ก N

$\wedge N 0^{\circ} 0^{\circ}$

$\infty$
$\infty$
1

๙ૅヘ ન の

i $\underbrace{1}$ -
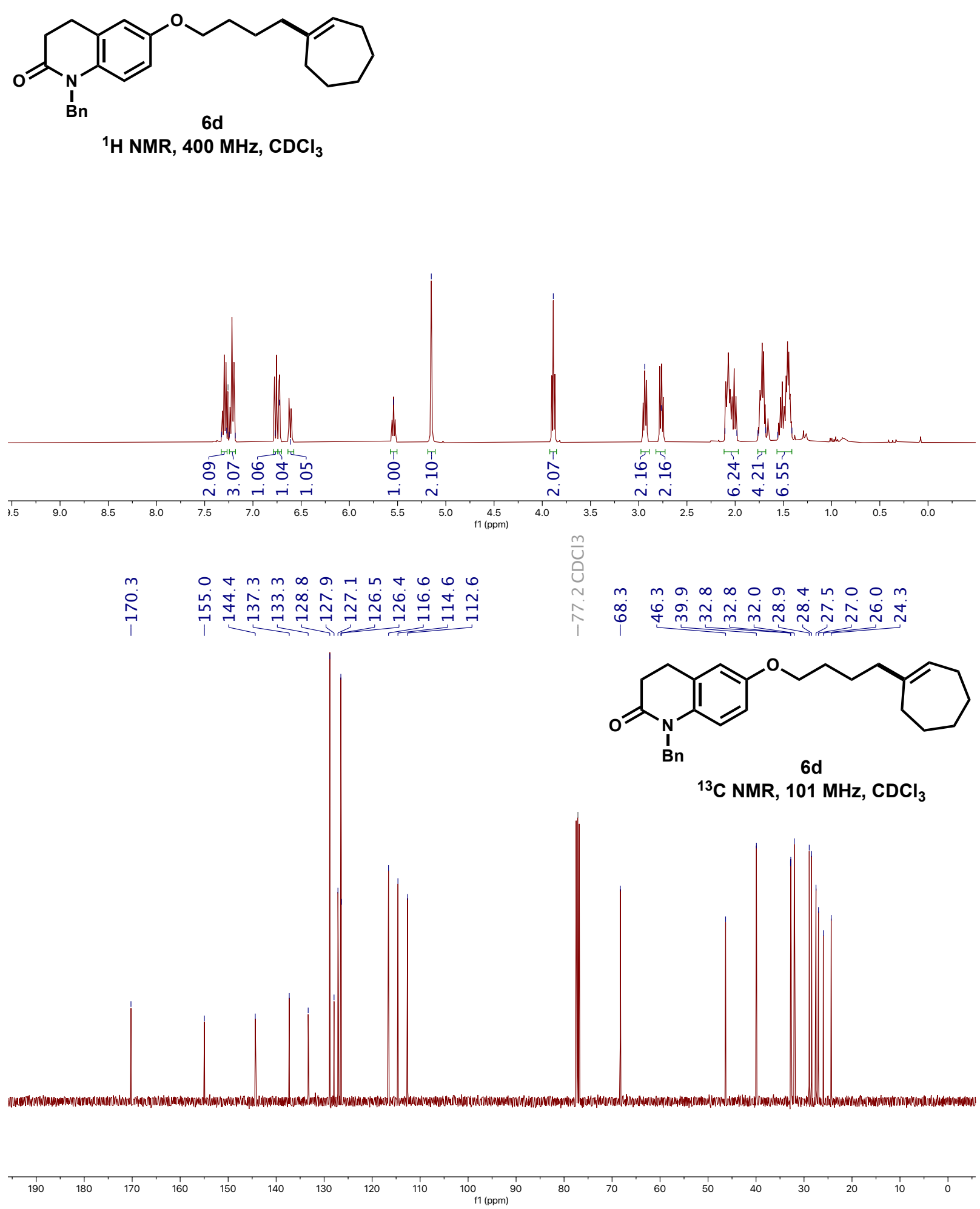
Supporting Information
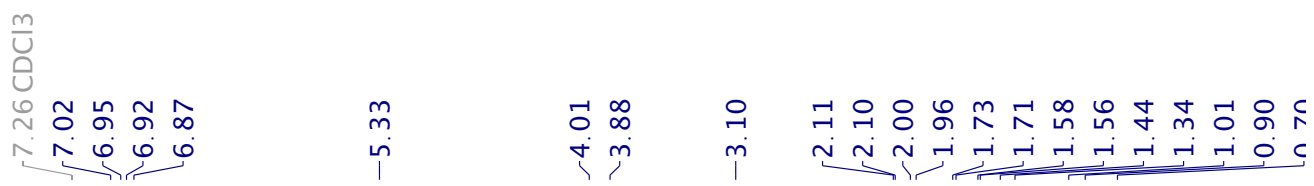<smiles>CC(C)C1CC[C@@H](C)C=C1CCCCOc1ccccc1N1CCOCC1</smiles>

${ }^{1} \mathrm{H}$ NMR, $400 \mathrm{MHz}, \mathrm{CDCl}_{3}$

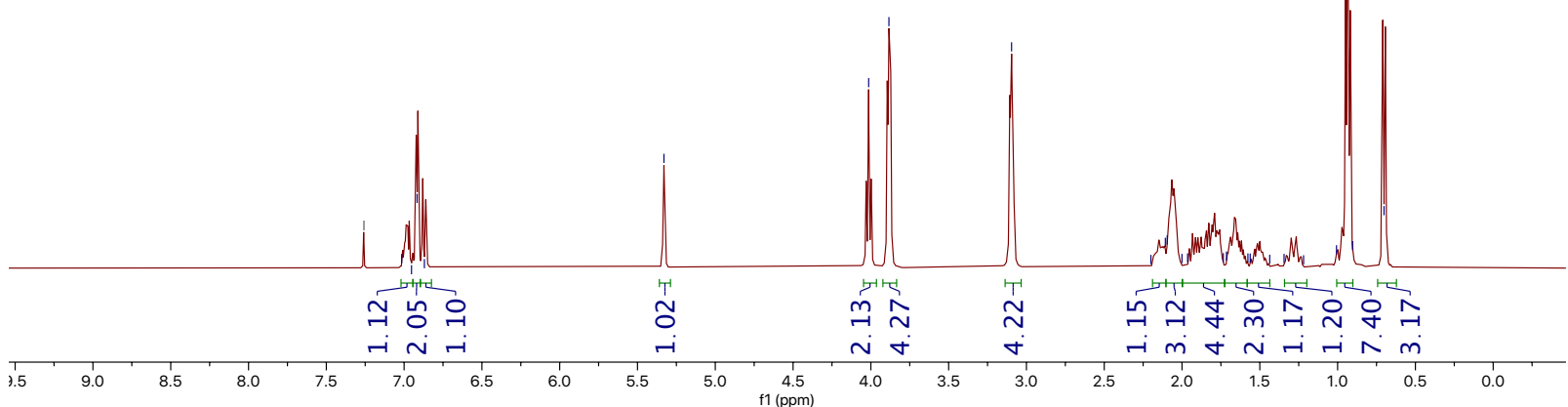

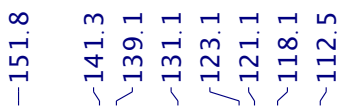
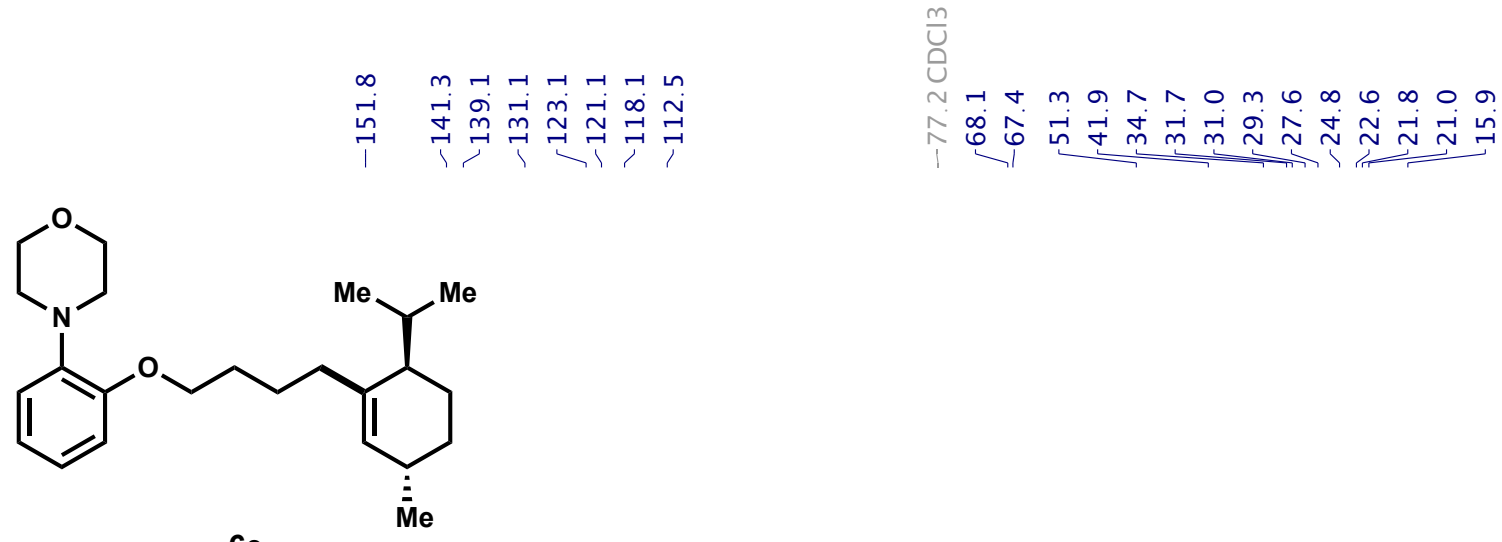

$6 e$

${ }^{13} \mathrm{C}$ NMR, $101 \mathrm{MHz}, \mathrm{CDCl}_{3}$
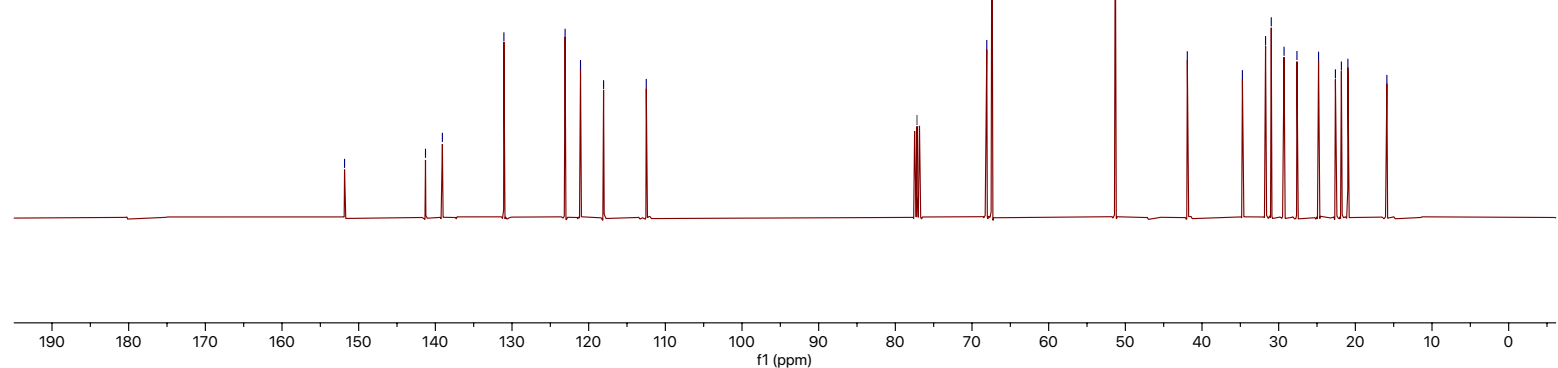
Supporting Information
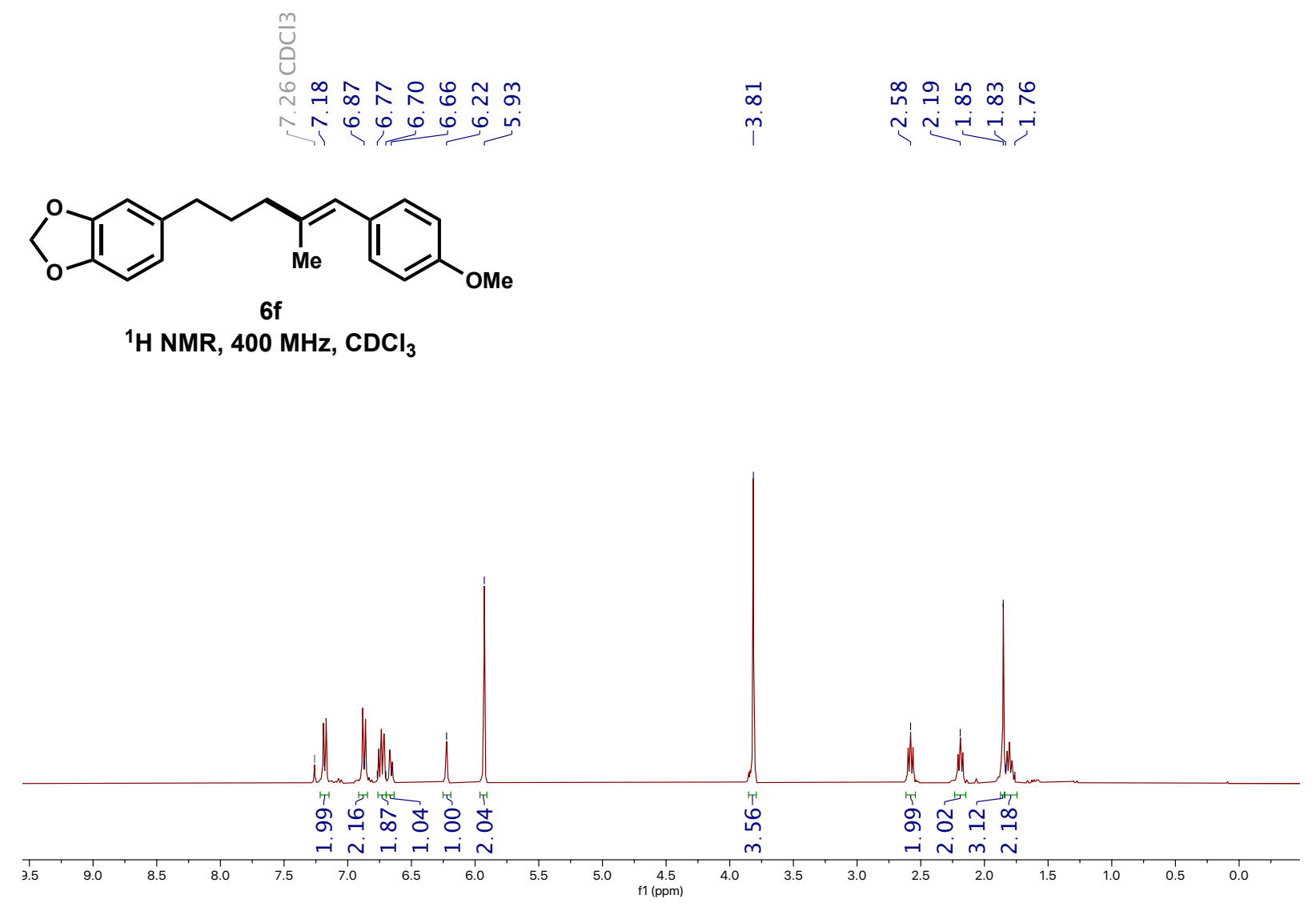

Ln $m m 0 N O N$ t $m$ m n m

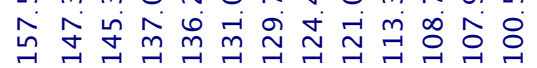

।<smiles>COc1ccc(/C=C(\N)CCCc2ccc3c(c2)OCO3)cc1</smiles>
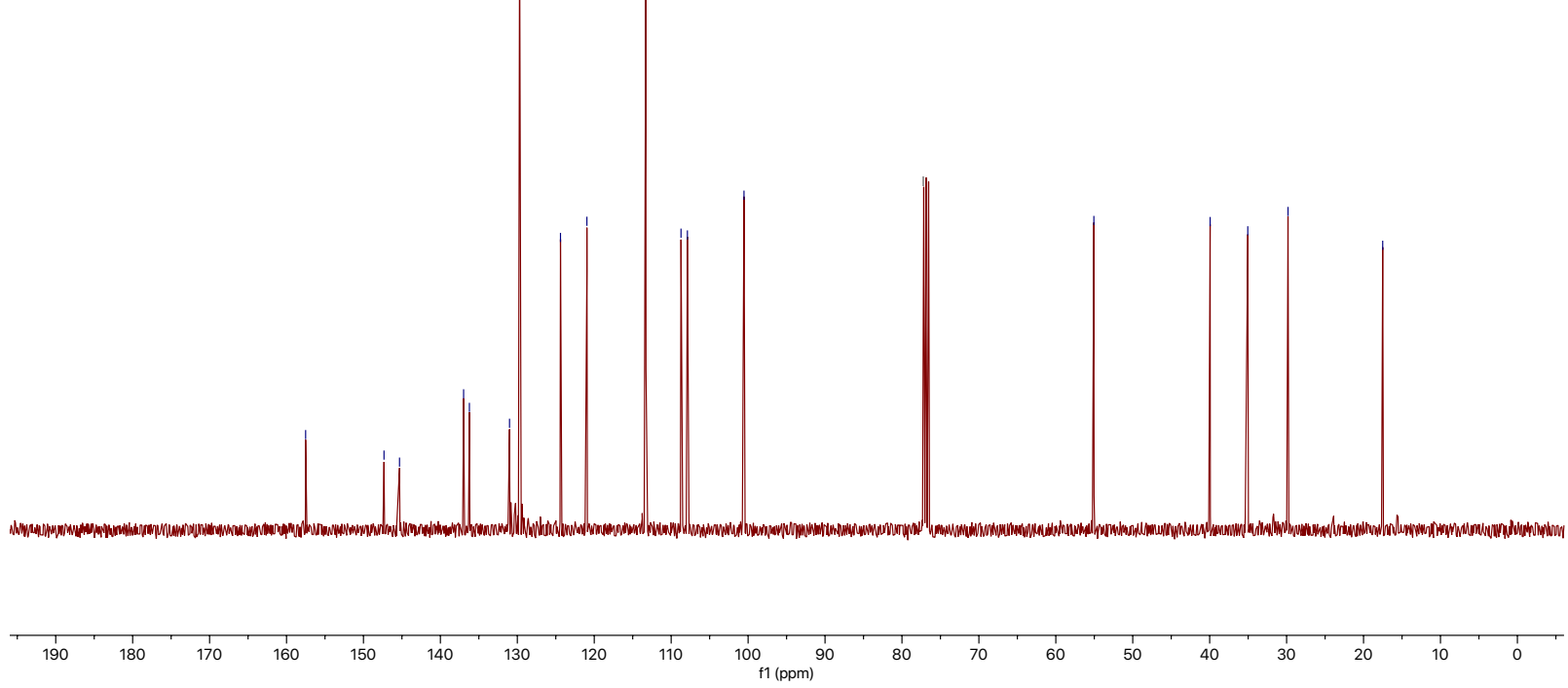
Supporting Information
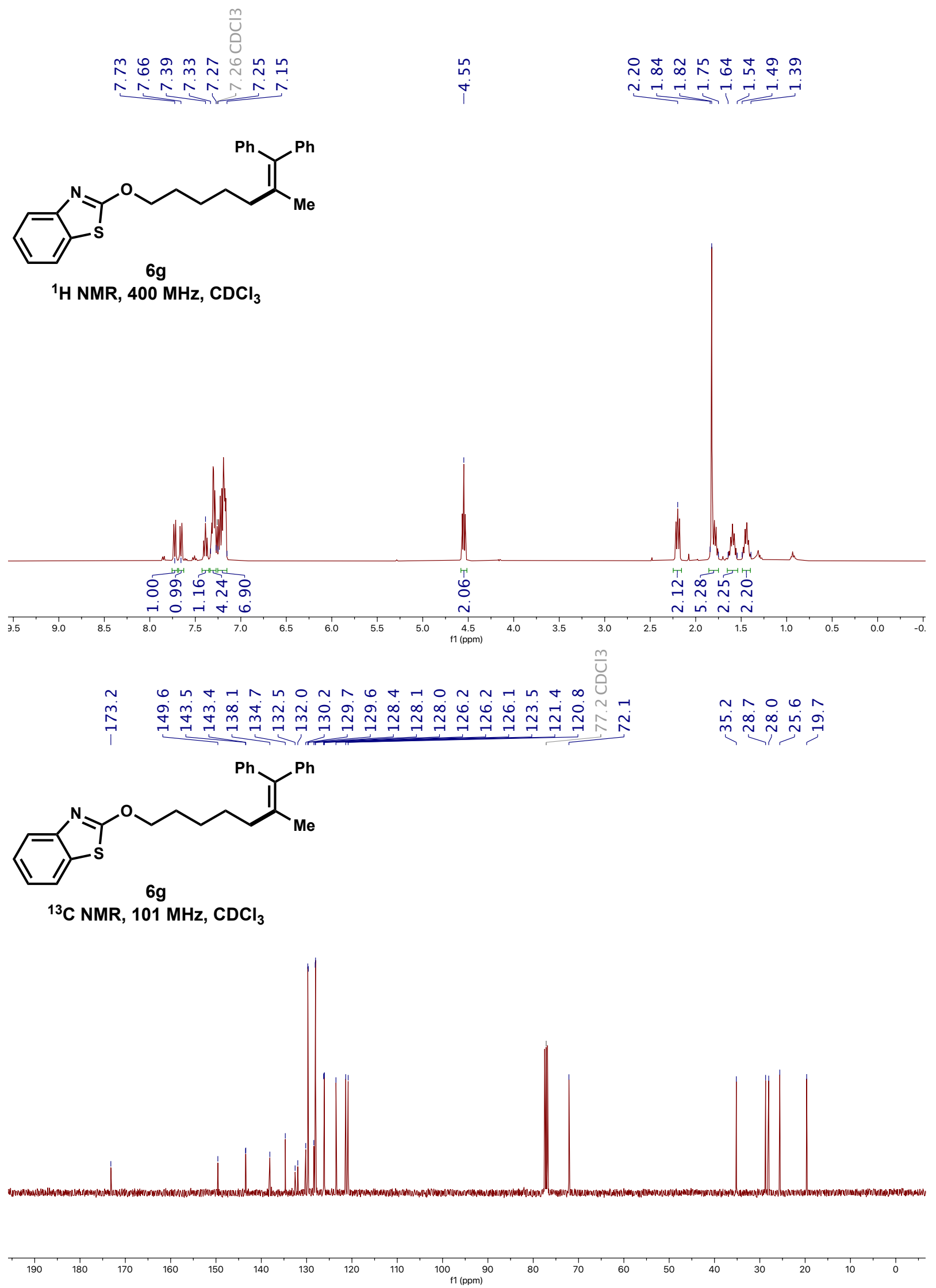
Supporting Information

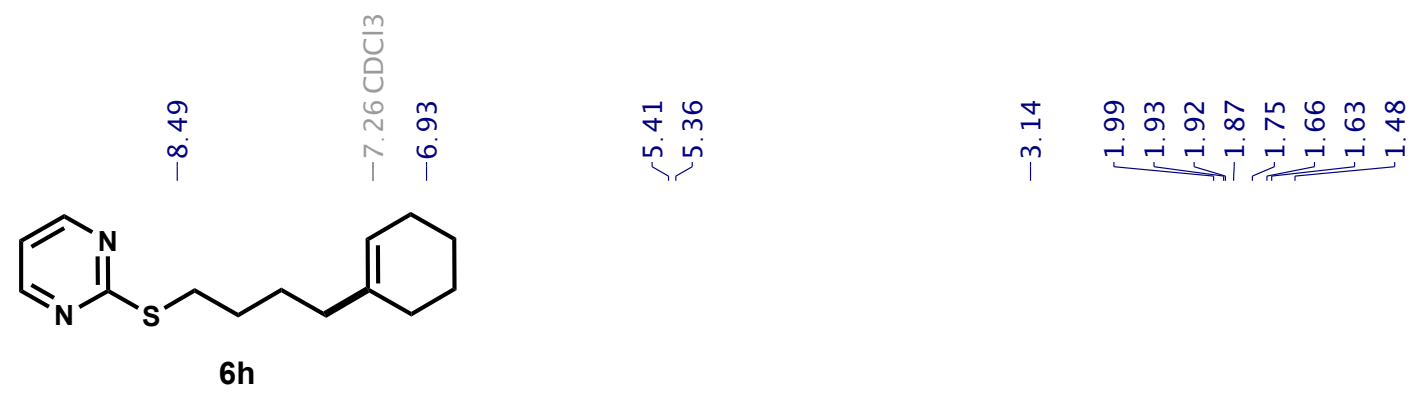

${ }^{1} \mathrm{H}$ NMR, $400 \mathrm{MHz}, \mathrm{CDCl}_{3}$

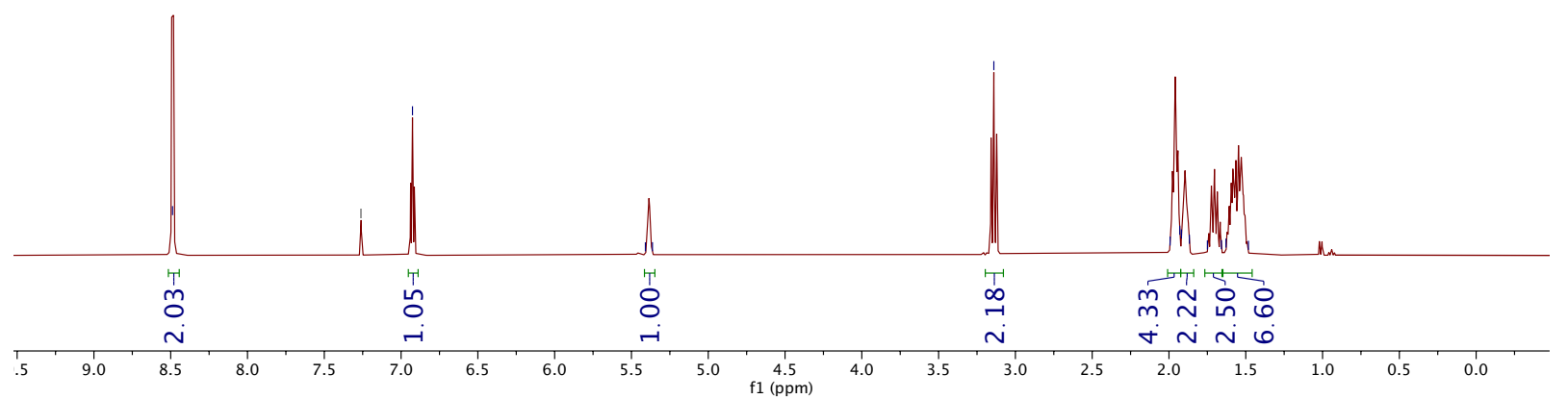

\begin{tabular}{|c|c|c|c|}
\hline o. & $m$ & Ln & $\sim m$ \\
\hline$\underset{-1}{\stackrel{n}{A}}$ & ถิก & $\hat{m}$ & $\underset{7}{\stackrel{\sim}{\sim}} \stackrel{0}{7}$ \\
\hline
\end{tabular}

o $\sigma \infty m \circ \forall-r$

$\hat{m} \stackrel{\infty}{\sim} \stackrel{\infty}{\sim} \stackrel{\sim}{\sim} \stackrel{\sim}{\sim}$<smiles>C1=C(CCCCSc2ncccn2)CCCC1</smiles>

$6 h$

${ }^{13} \mathrm{C}$ NMR, $101 \mathrm{MHz}, \mathrm{CDCl}_{3}$

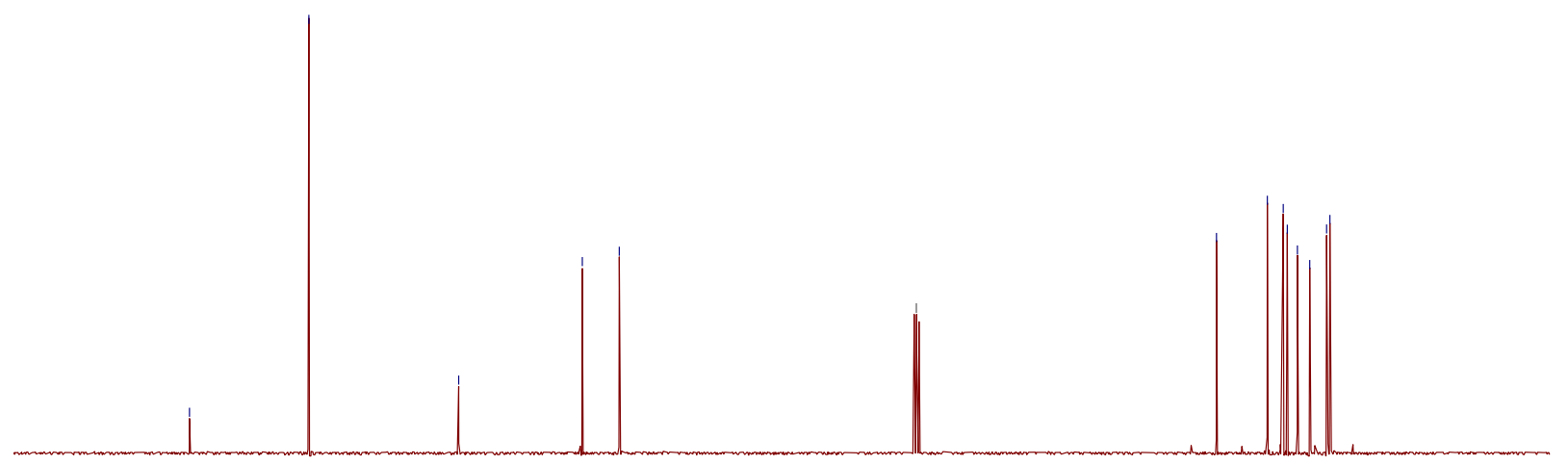

$\begin{array}{rllllllllllllllllll}190 & 180 & 170 & 160 & 150 & 140 & 130 & 120 & 110 & \underset{\mathrm{f} 1(\mathrm{ppm})}{100} & 80 & 70 & 60 & 50 & 40 & 30 & 20 & 10 & 0\end{array}$ 
Supporting Information

\subsection{Chiral SFC and HPLC Traces of Olefin Hydroalkenylation Products}

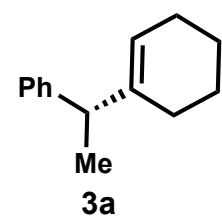

GB1_112_rep5
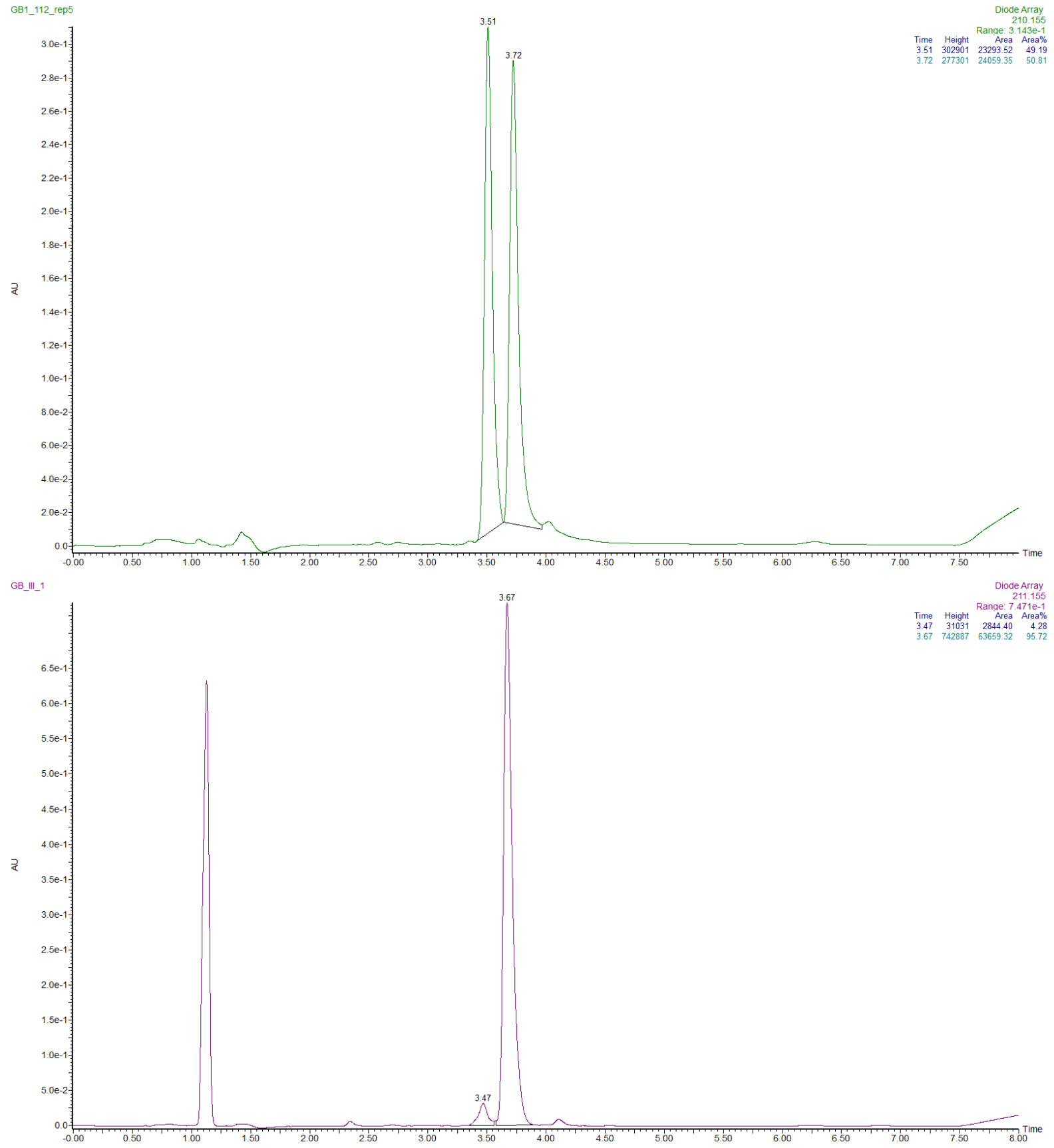
Supporting Information<smiles>[C-]#[N+][C@@H](C1=Cc2cc(OC)ccc2CC1)c1ccccc1</smiles>
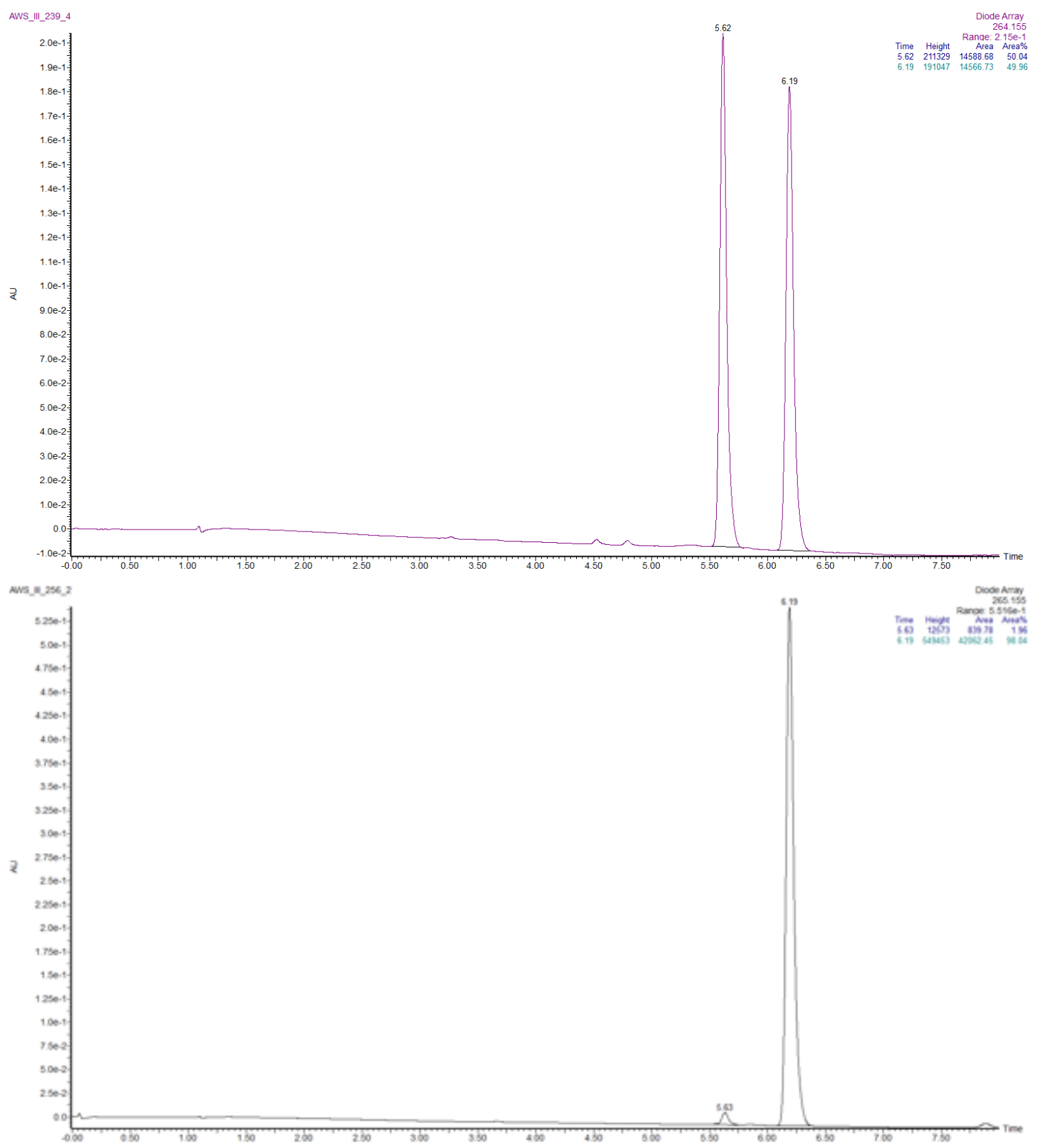
Supporting Information

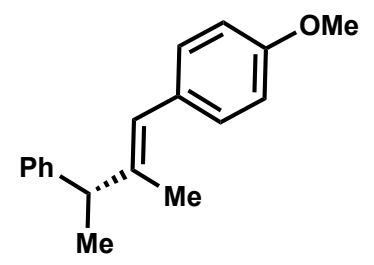

$3 c$
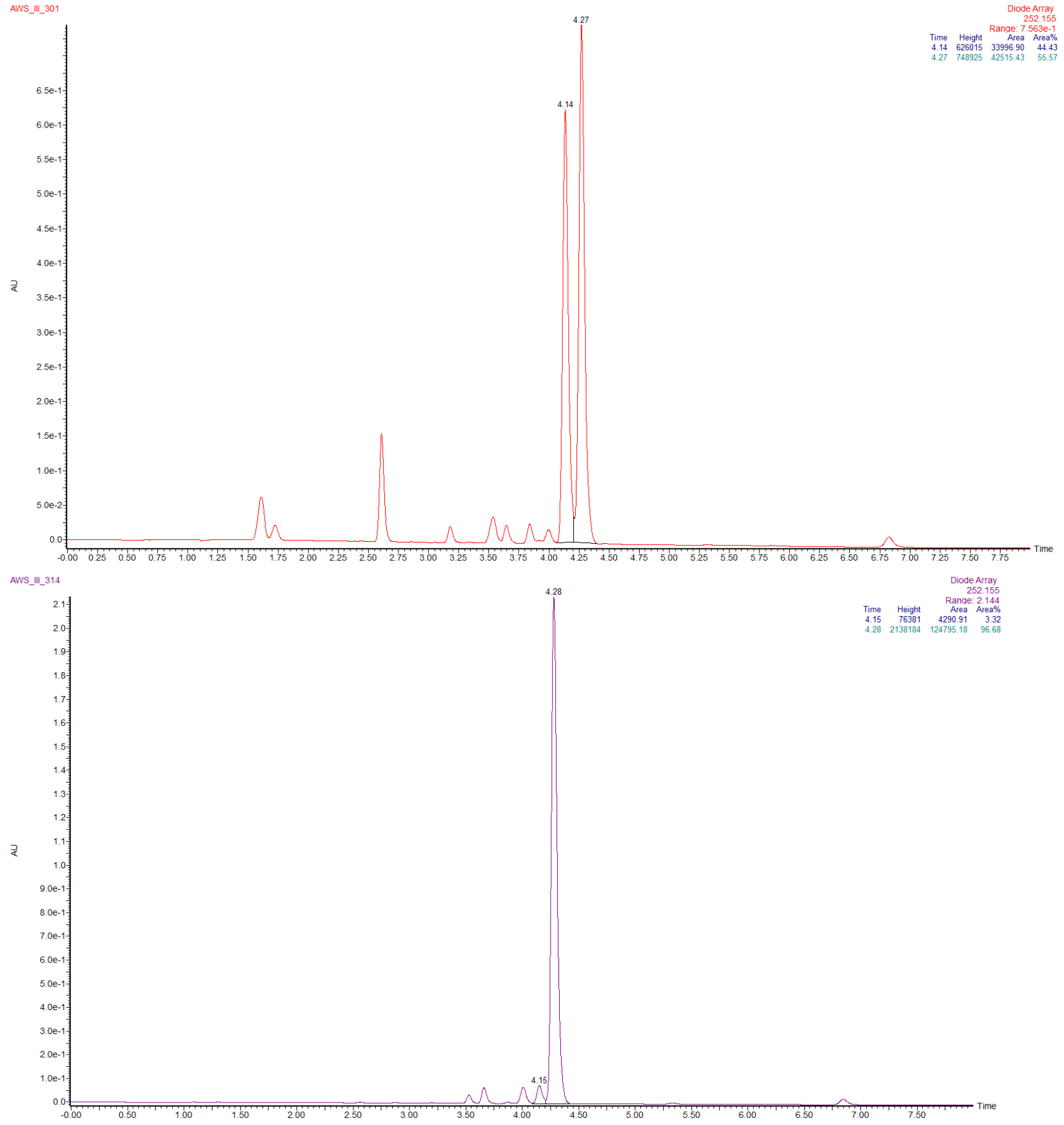
Supporting Information
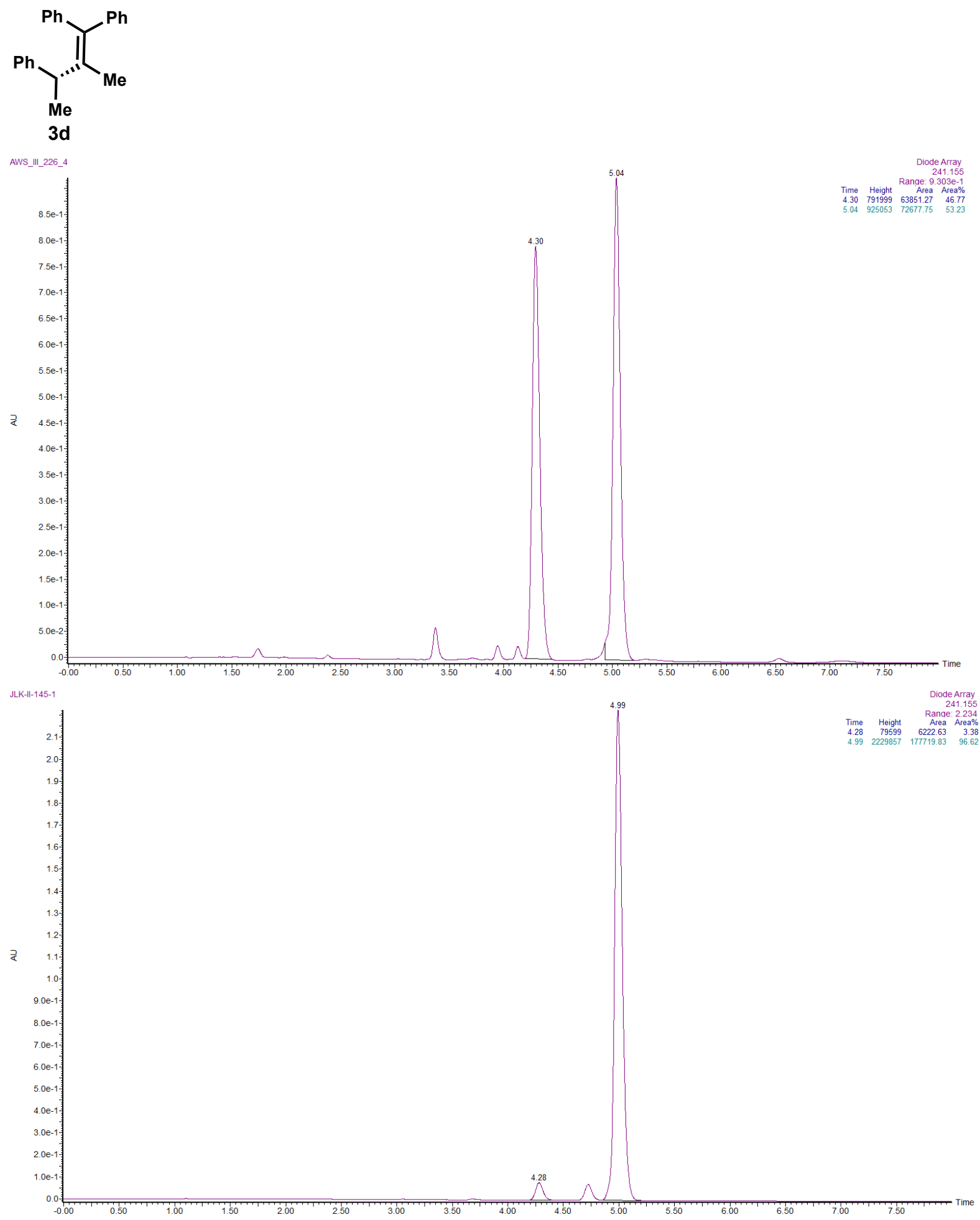
Supporting Information
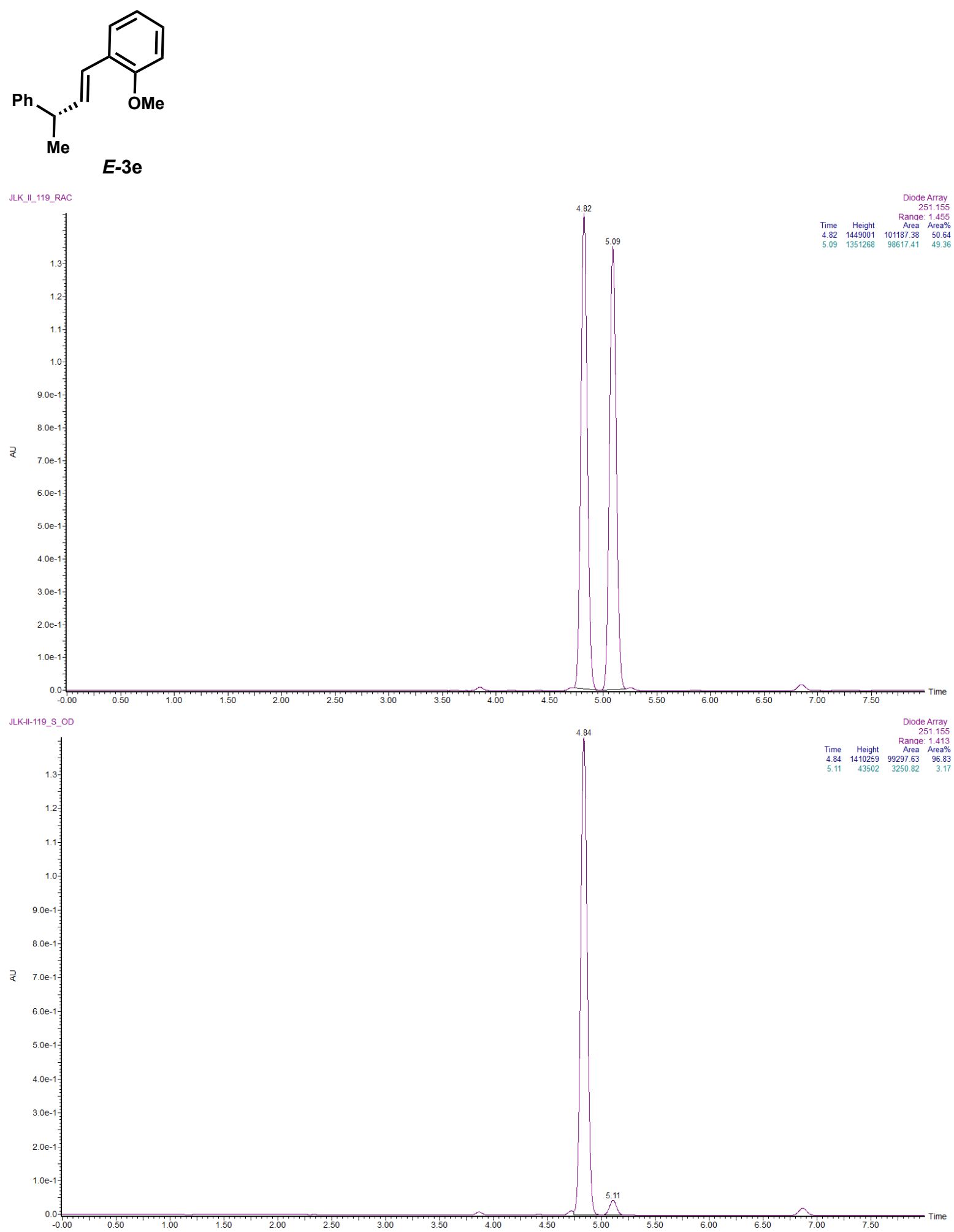
Supporting Information
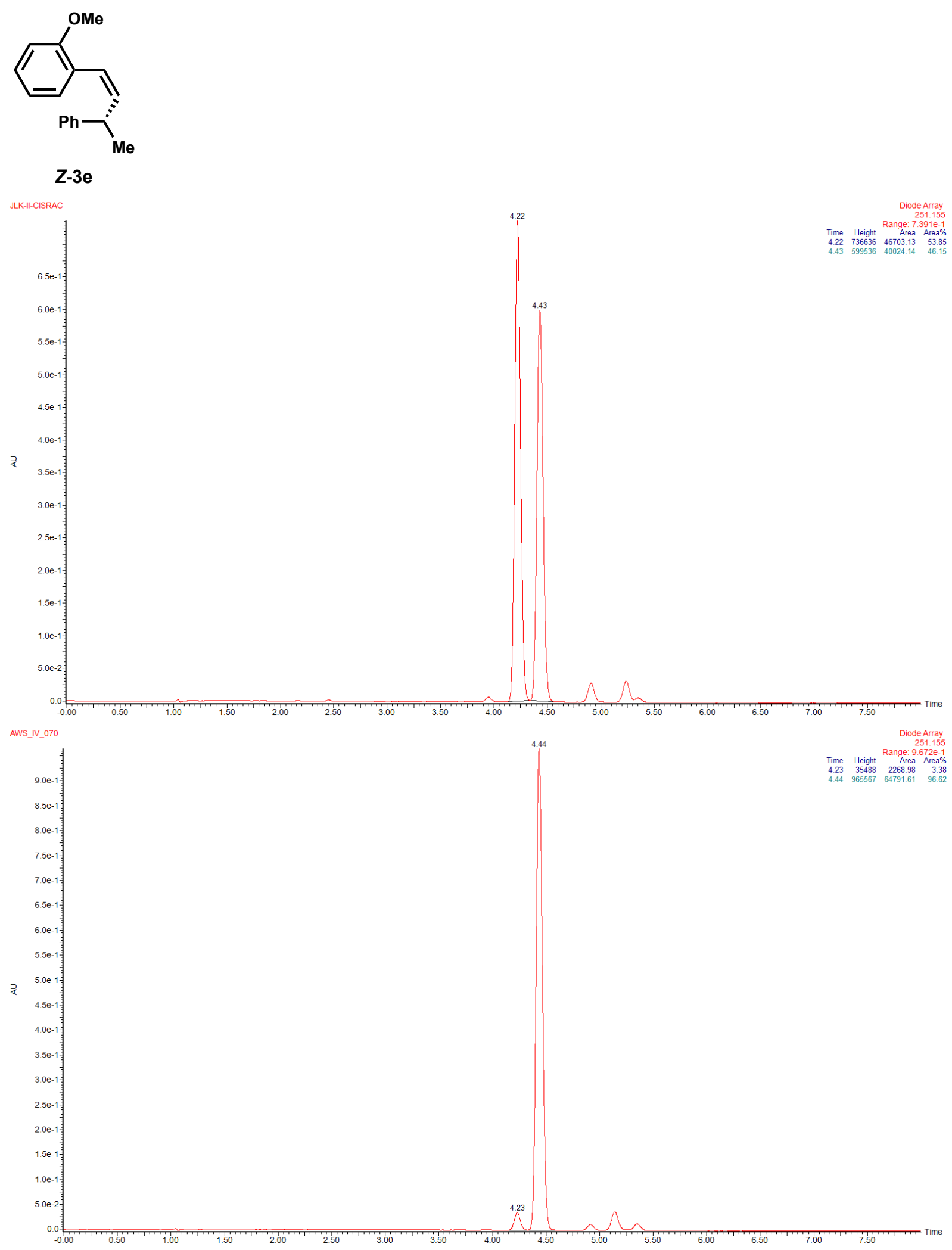
Supporting Information
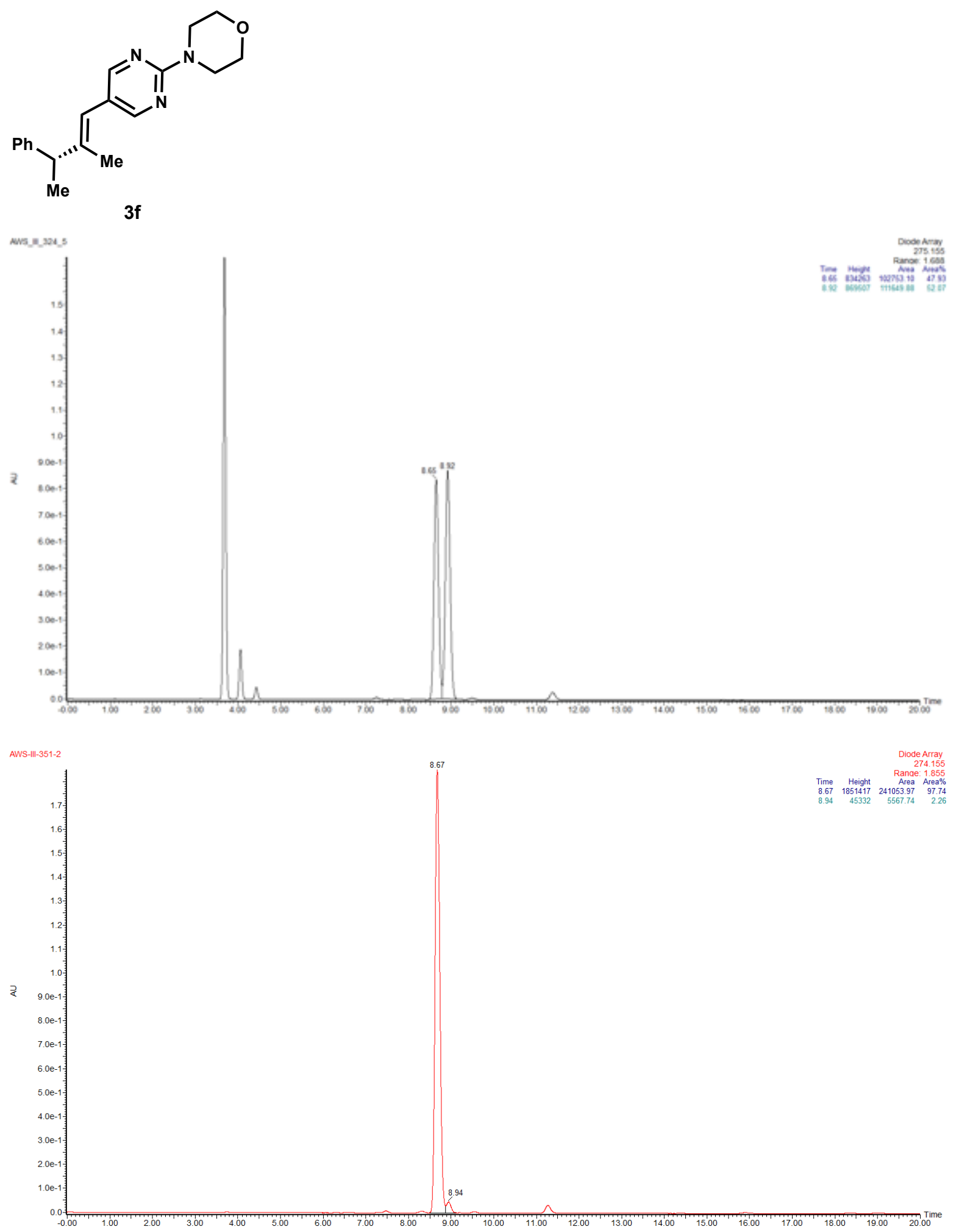
Supporting Information

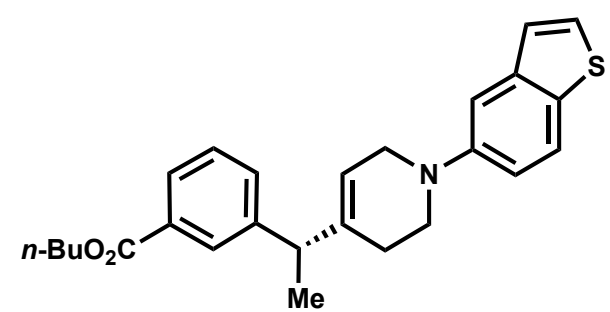

$3 g$

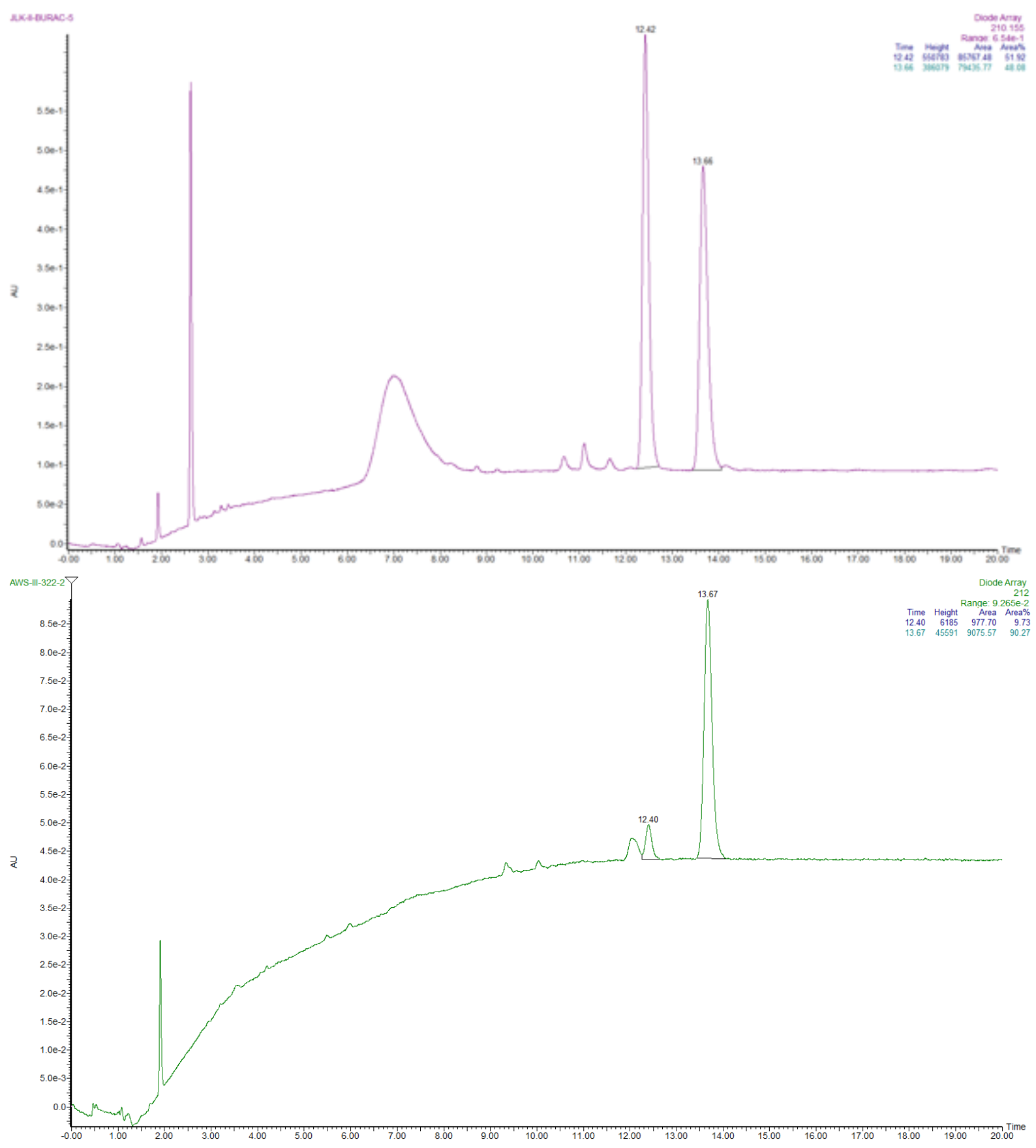


Supporting Information

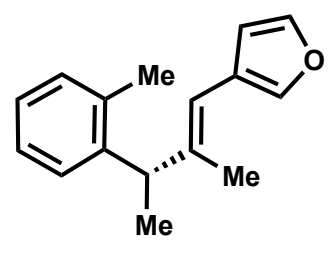

3h

AwS_III_364_2
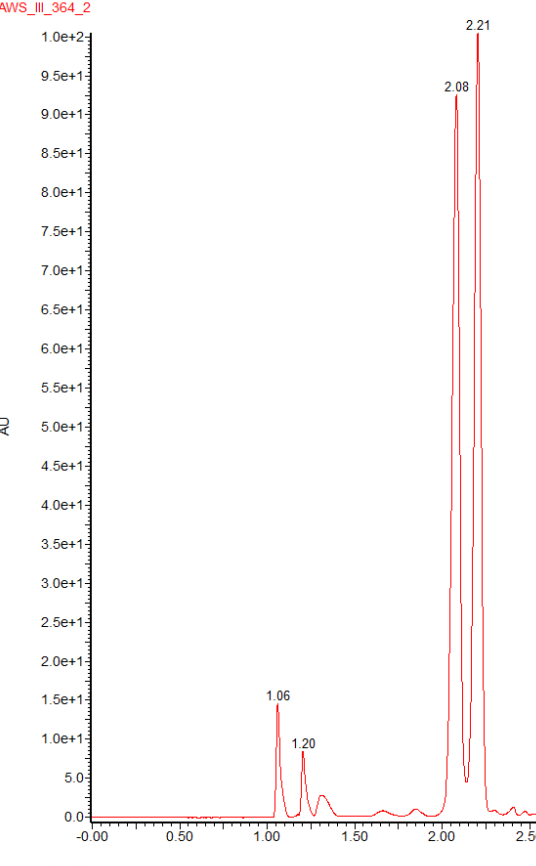

Diode Array
Range: $1.009 \mathrm{e}+2$

NKA.06T-OA-

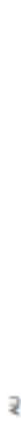

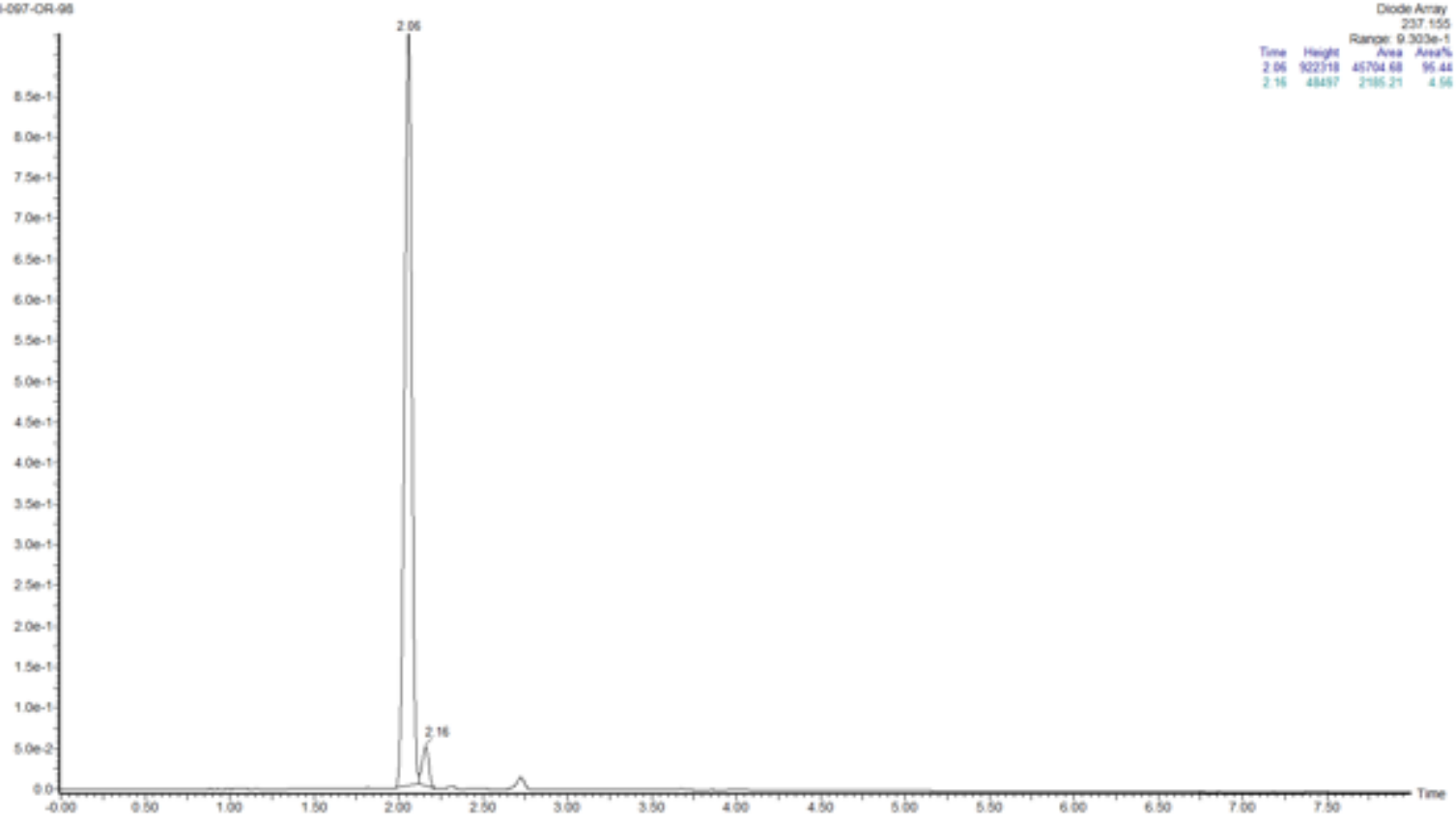


Supporting Information

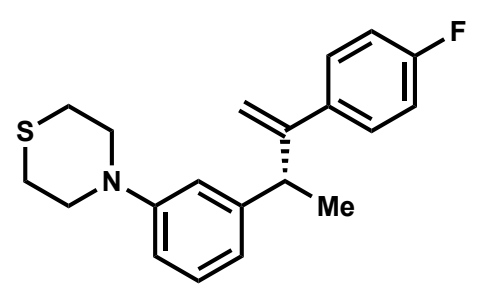

$3 \mathbf{i}$
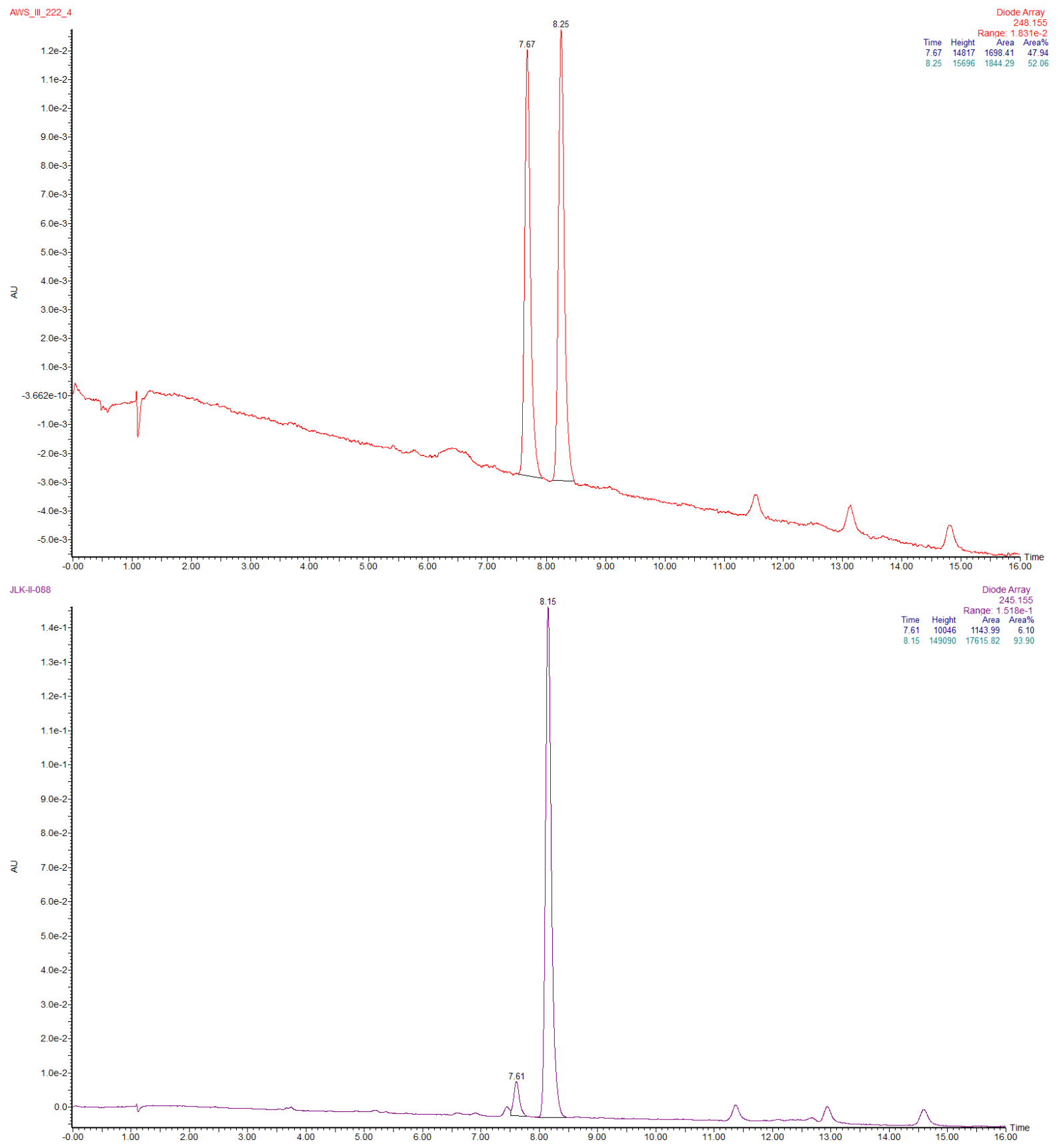
Supporting Information<smiles>[B]N1CC=C([C@H](C)c2ccc3occc3c2)CC1</smiles>
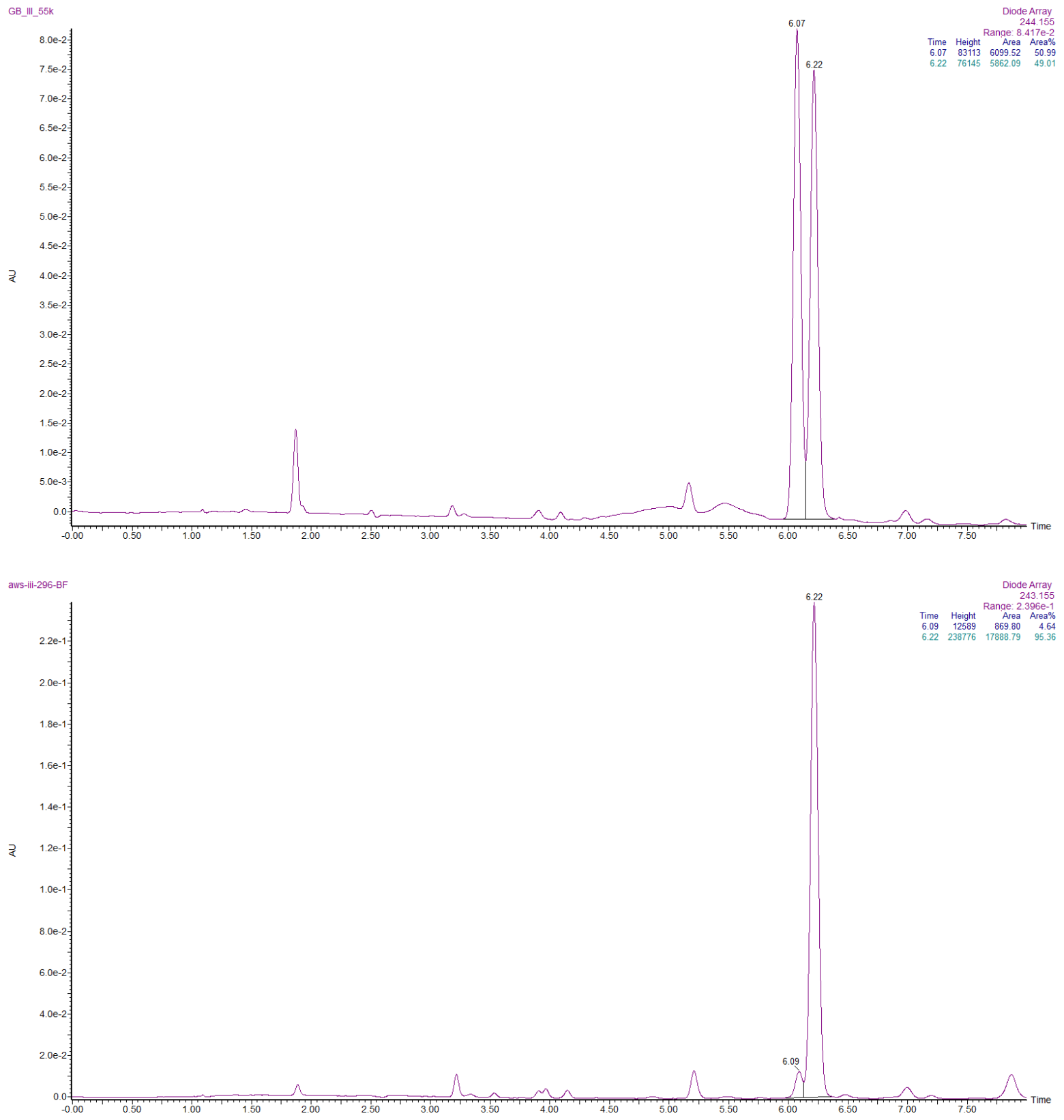
Supporting Information
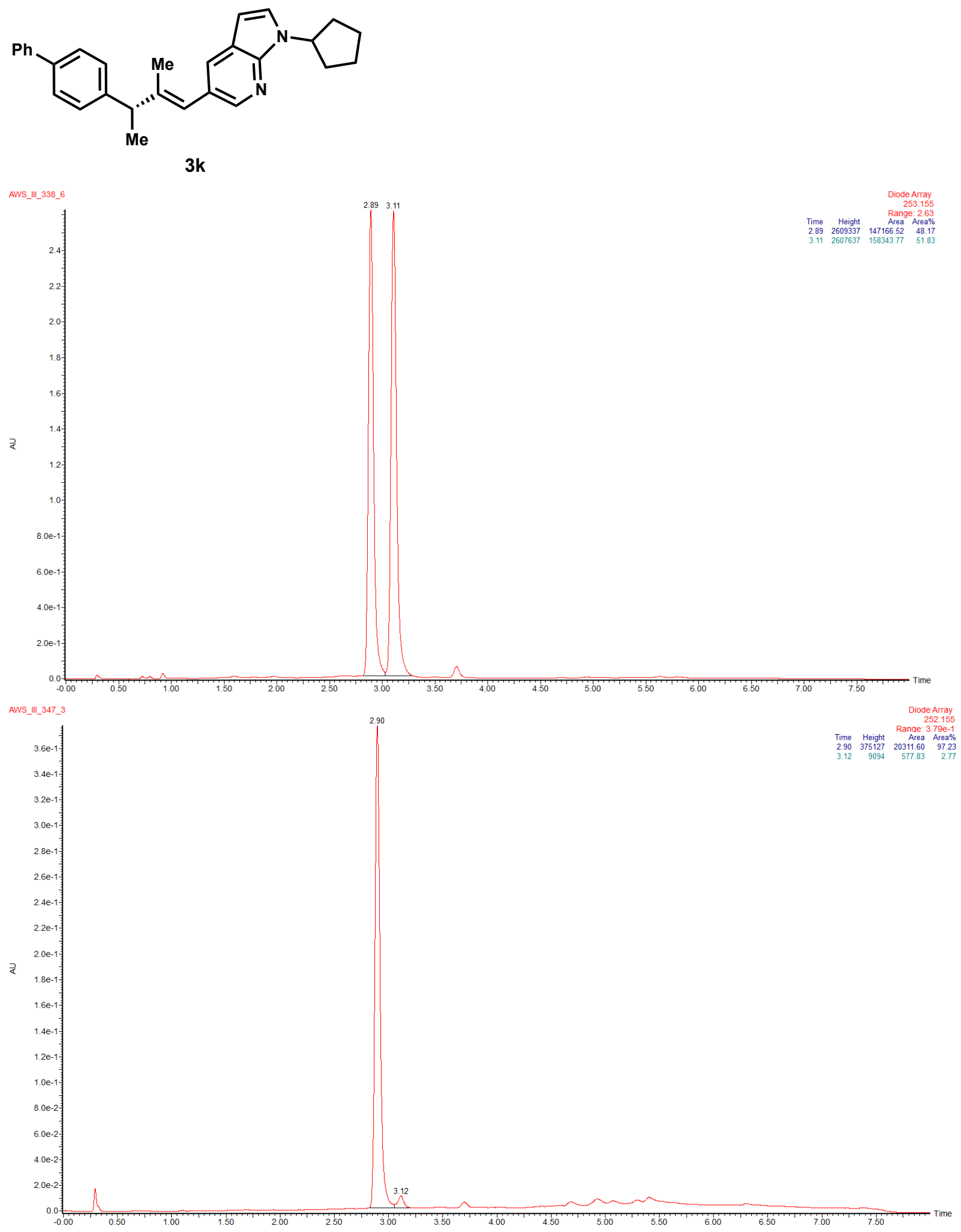
Supporting Information<smiles>COc1ccc(/C=C(\C)[C@H](C)c2ccc(OC)c(Cl)c2)cc1</smiles>

3I

AWS_III_407_9

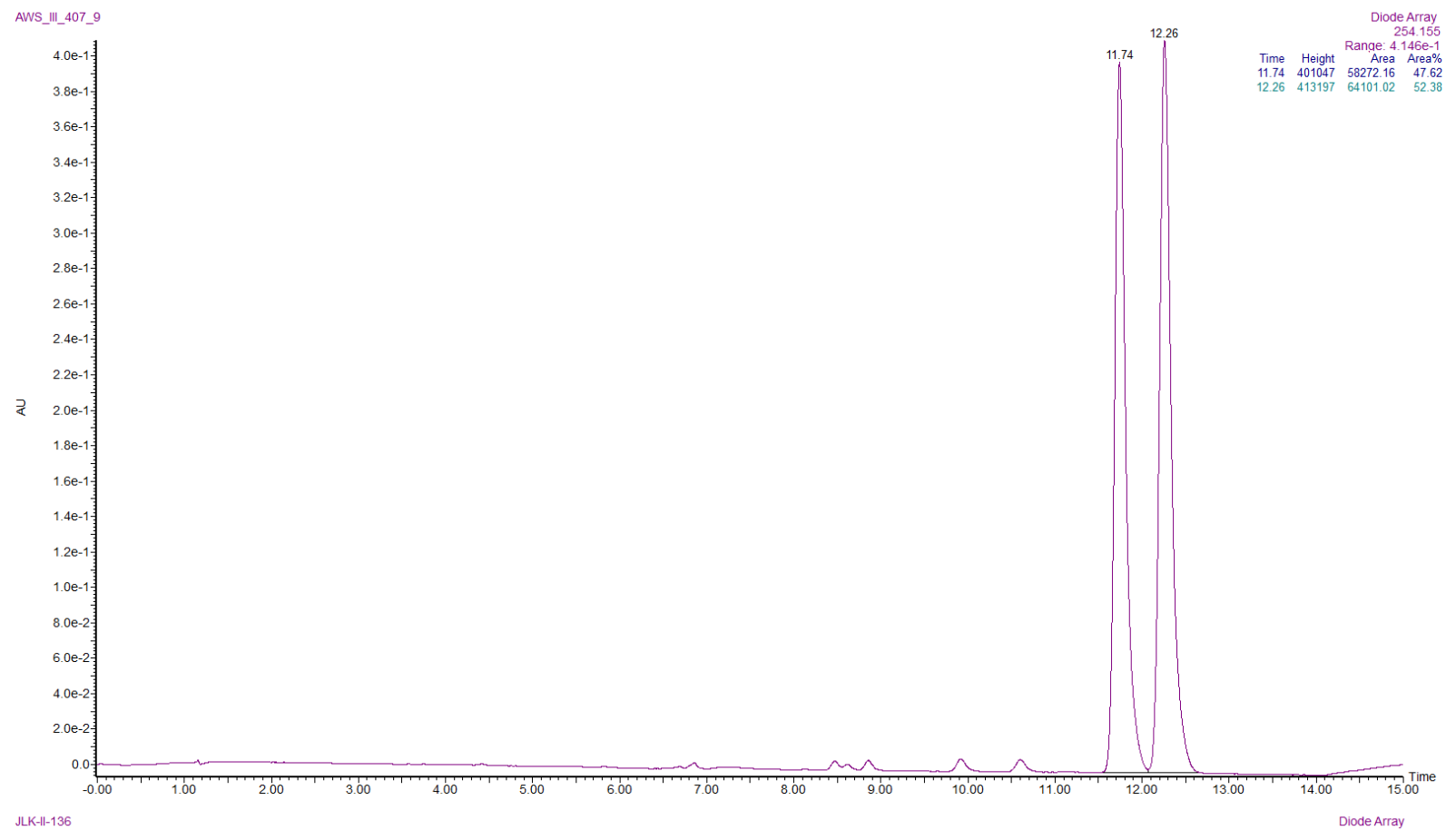
JLK-II-136

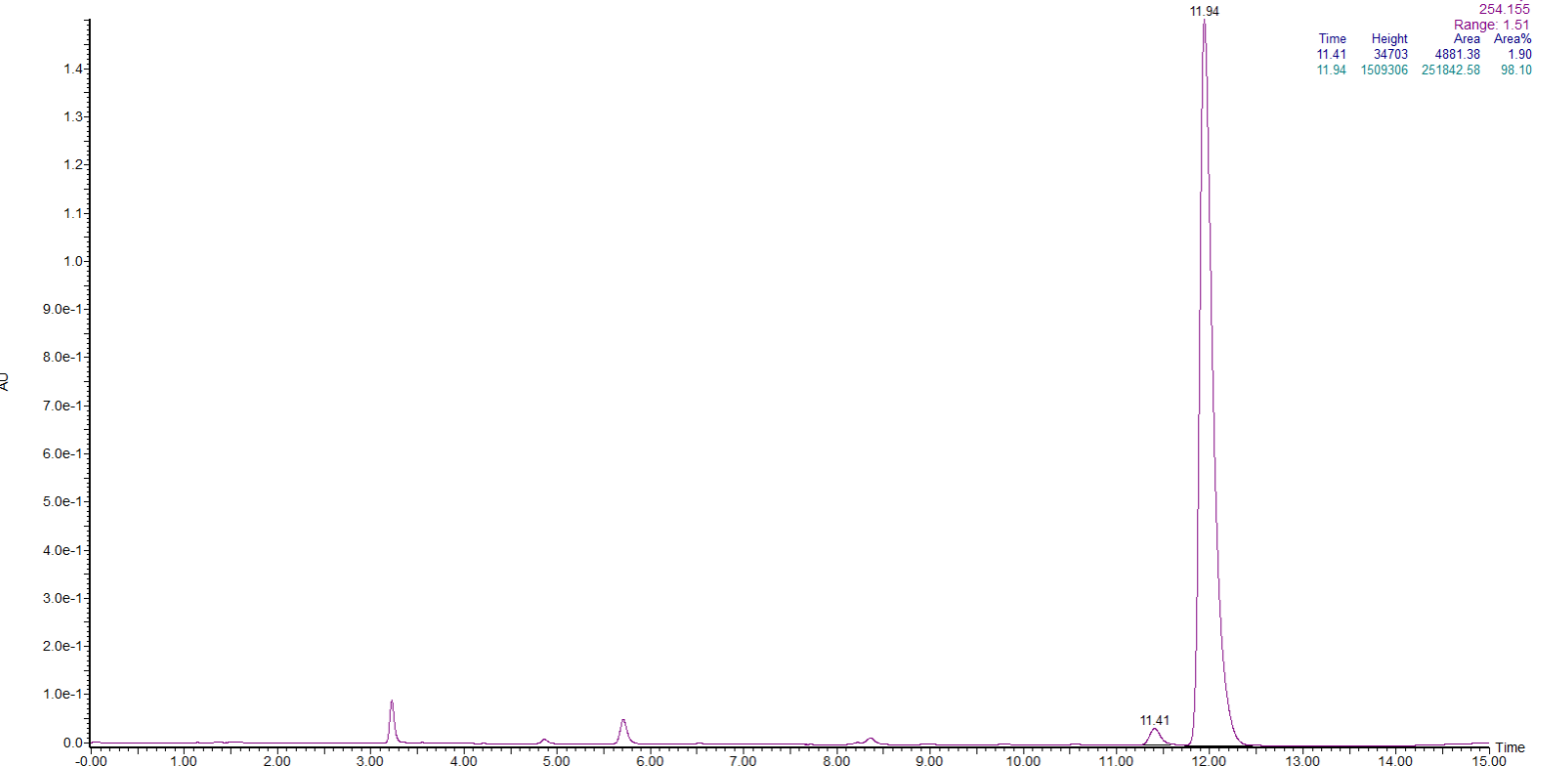


Supporting Information

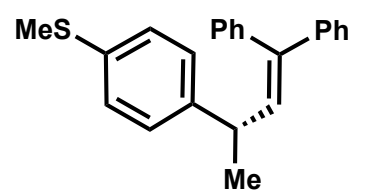

$3 m$
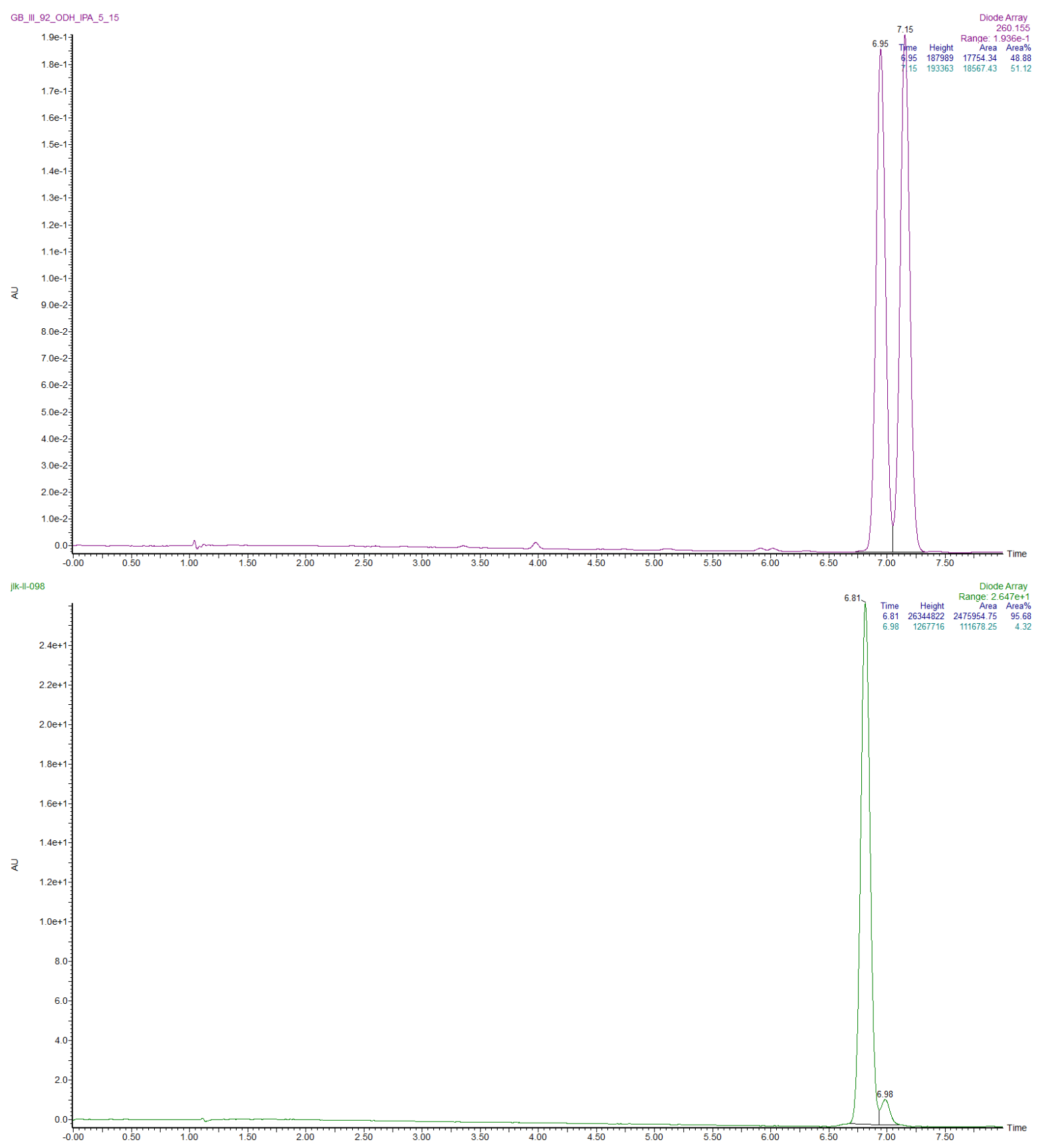
Supporting Information<smiles>CCn1c2ccccc2c2cc([C@H](C)C3=C(c4ccccc4)CCCC3)ccc21</smiles>
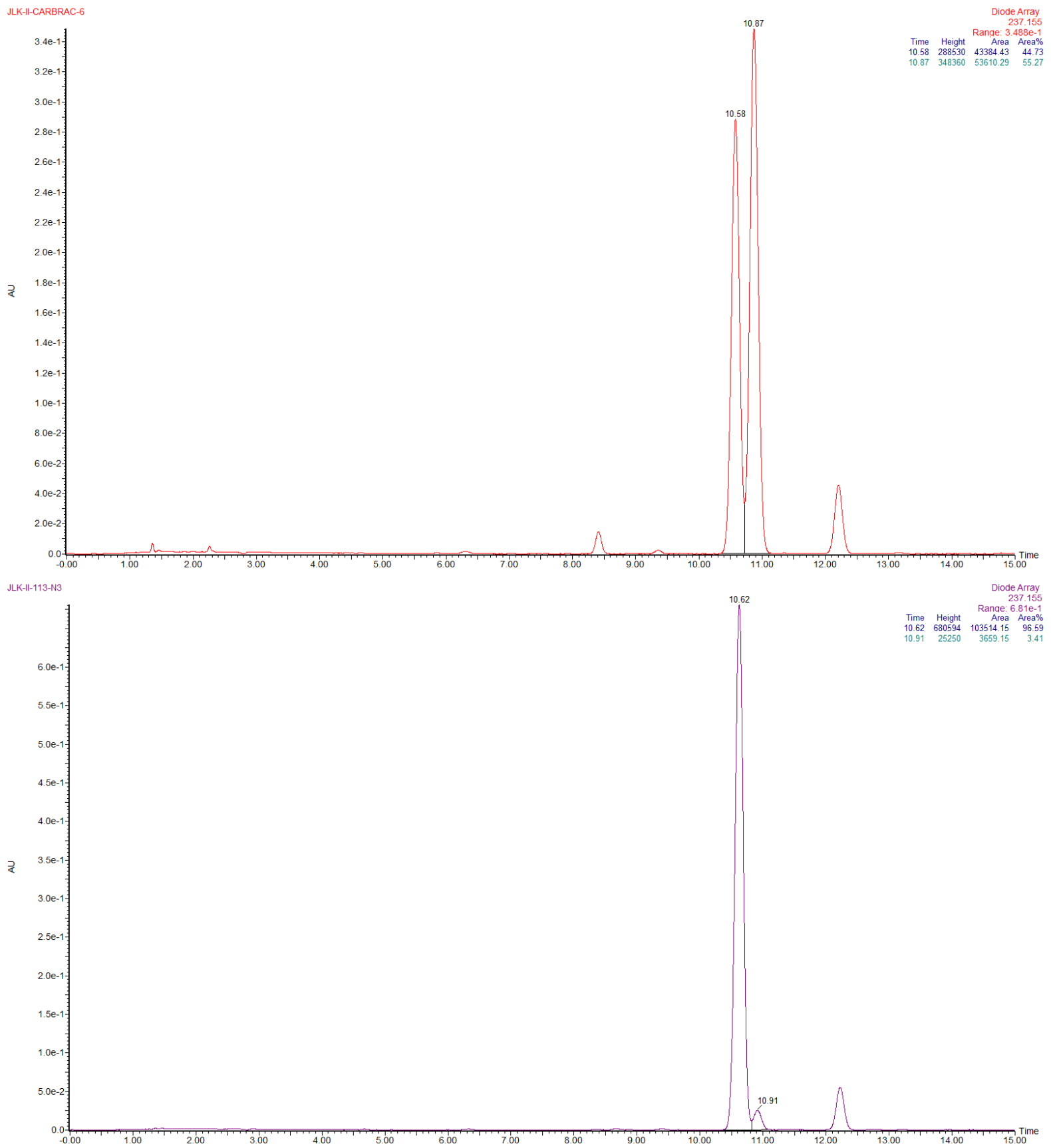
Supporting Information
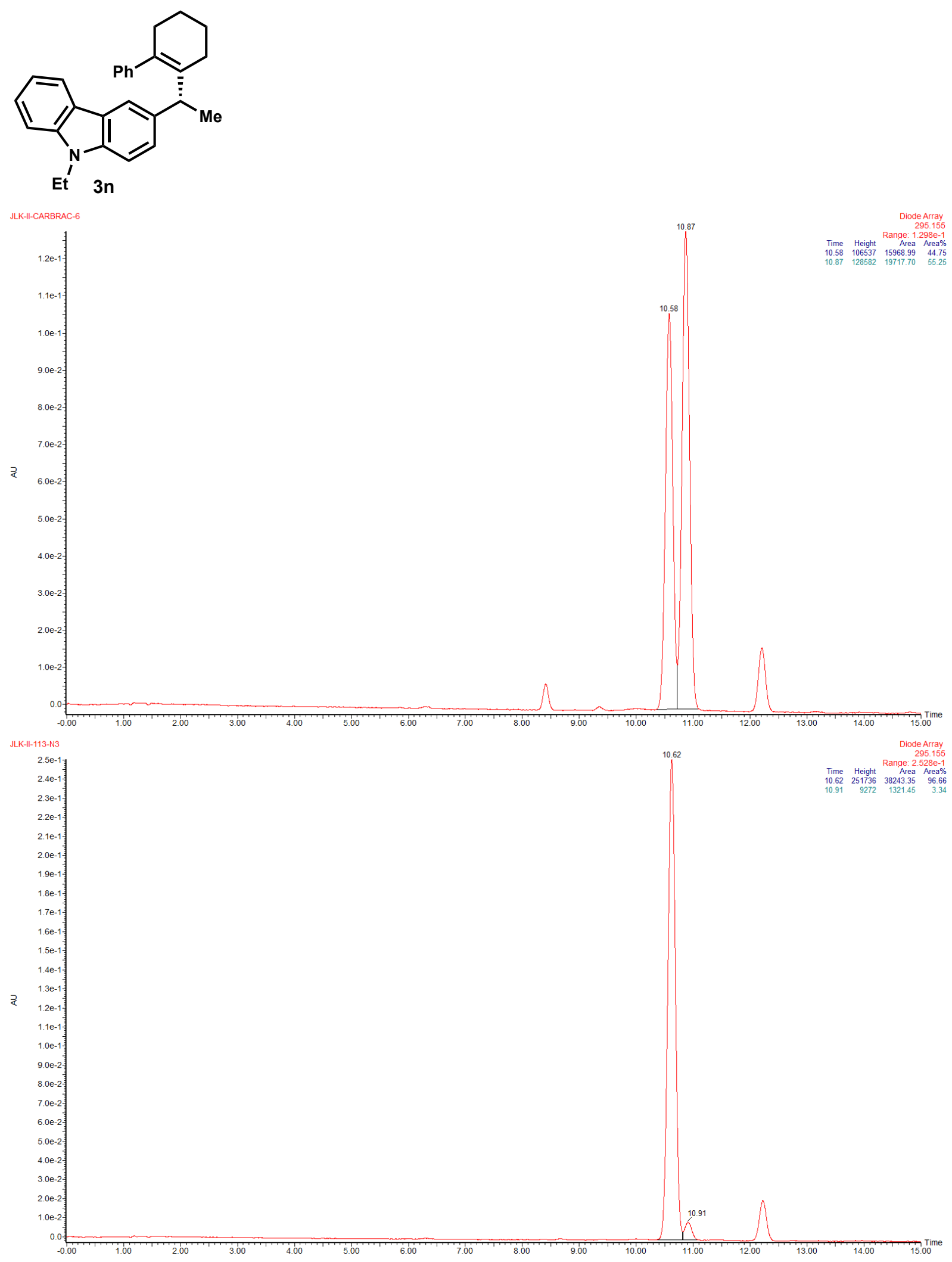
Supporting Information
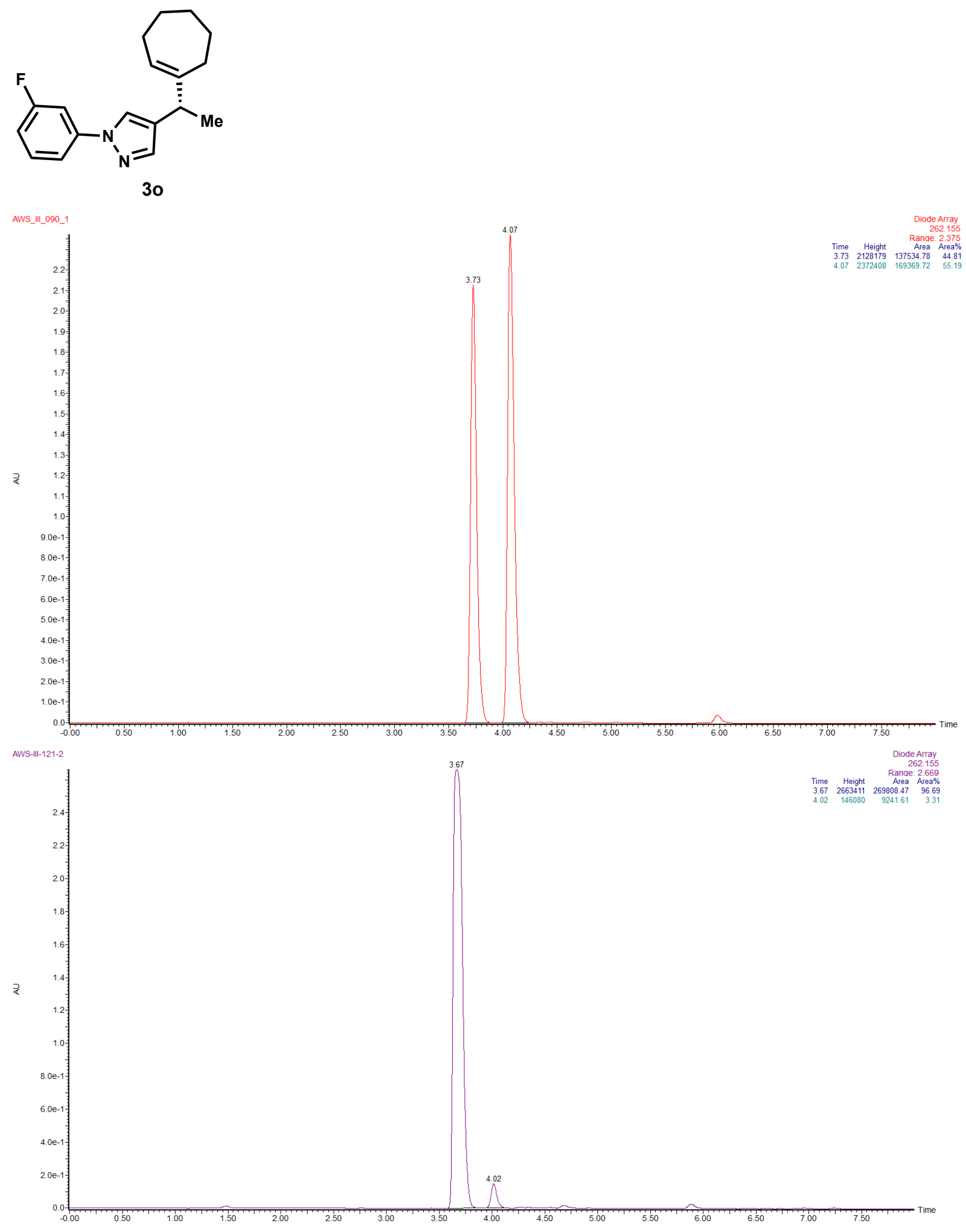
Supporting Information
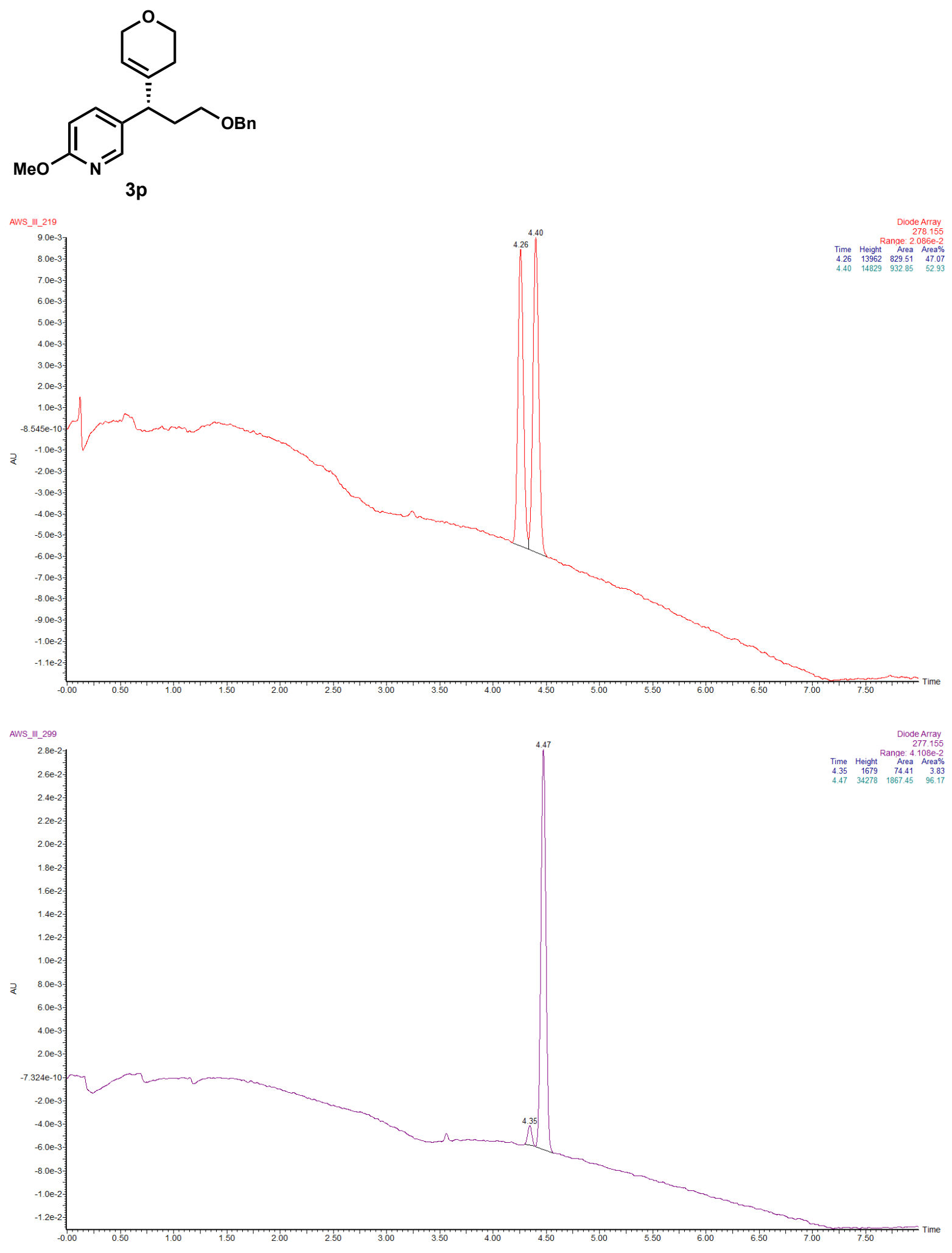
Supporting Information
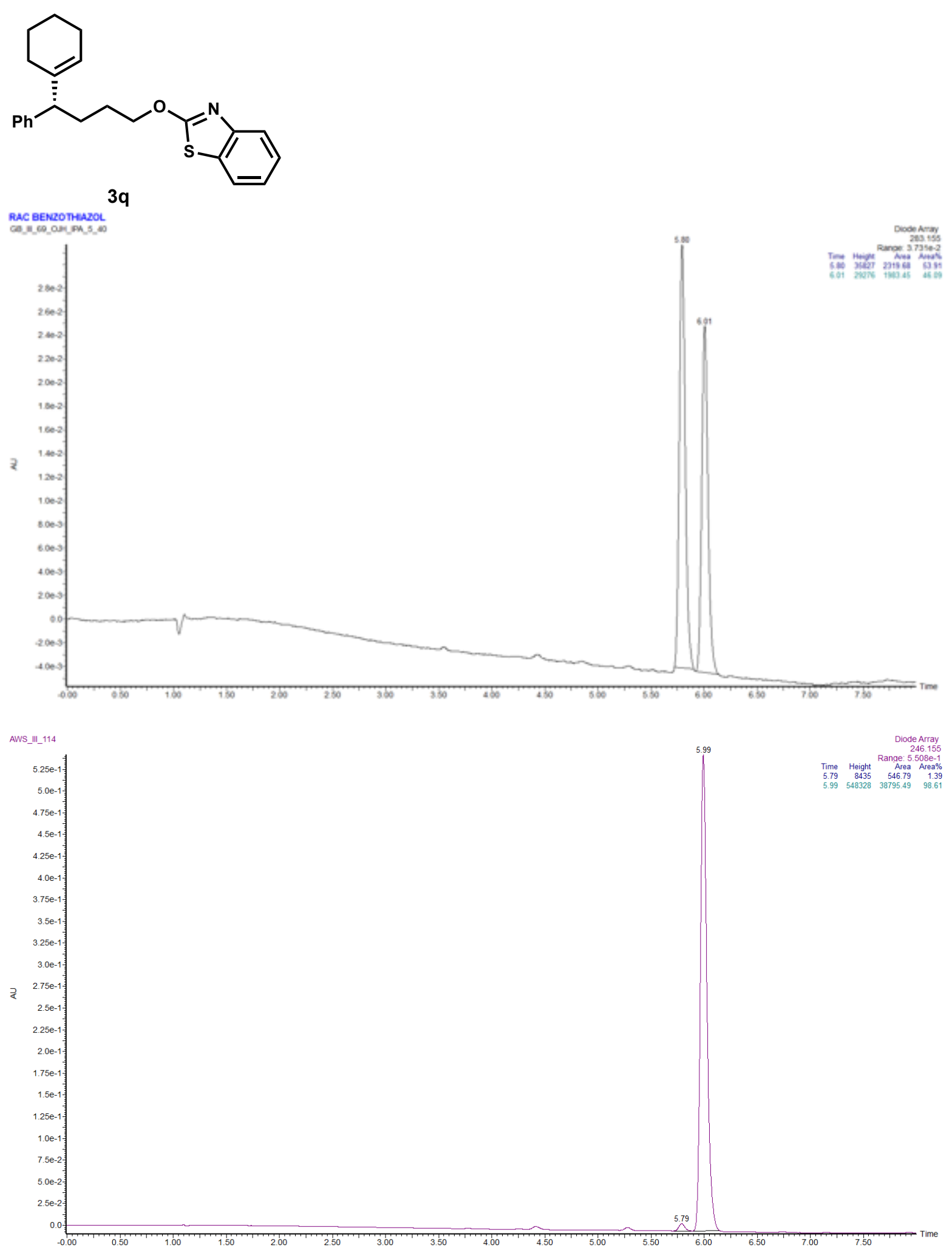
Supporting Information
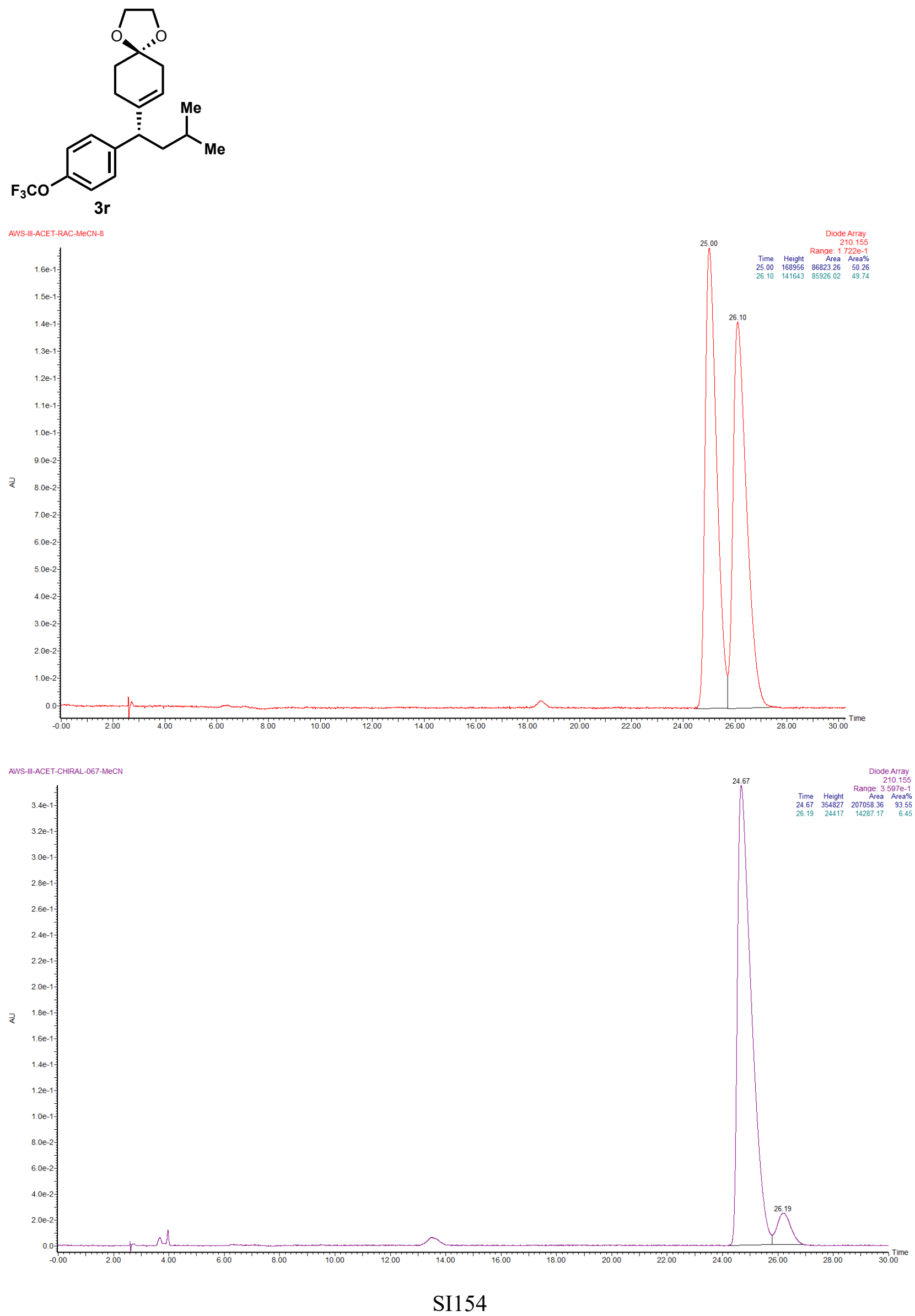
Supporting Information
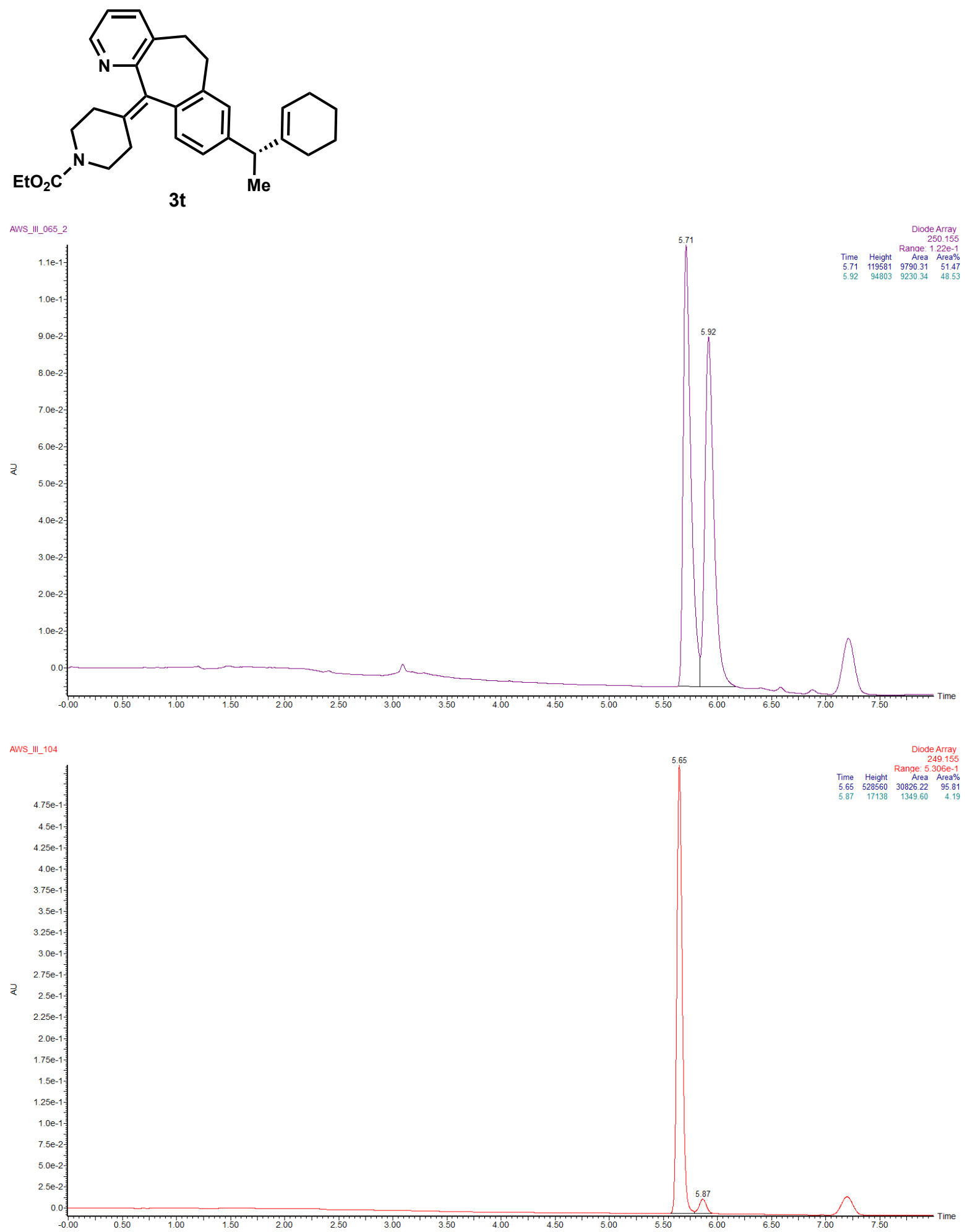
Supporting Information
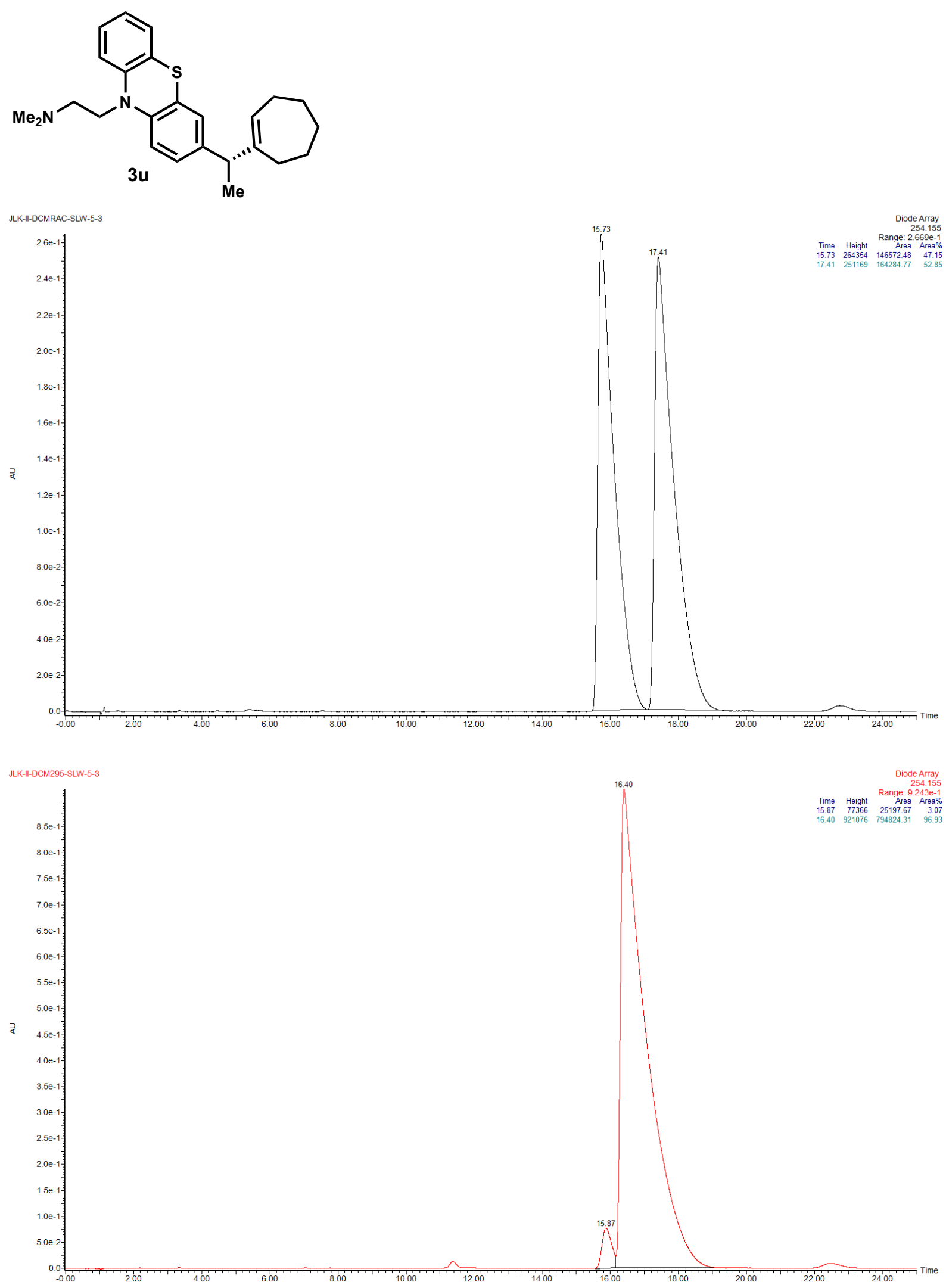
Supporting Information
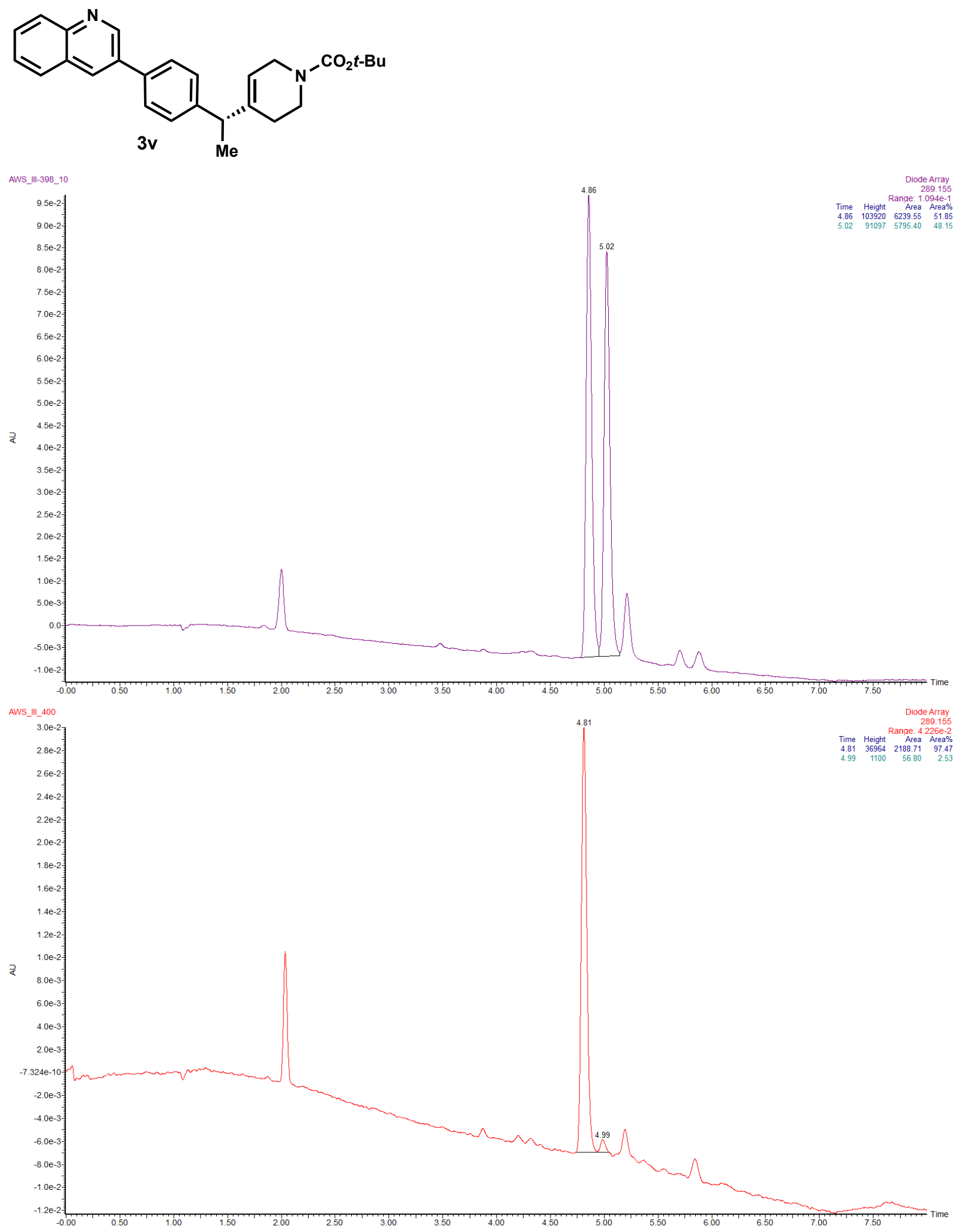
Supporting Information<smiles>C[C@H](C1=CCN(C(=O)OC(C)(C)C)CC1)c1ccc(-c2cnc3ccccc3c2)cc1</smiles>

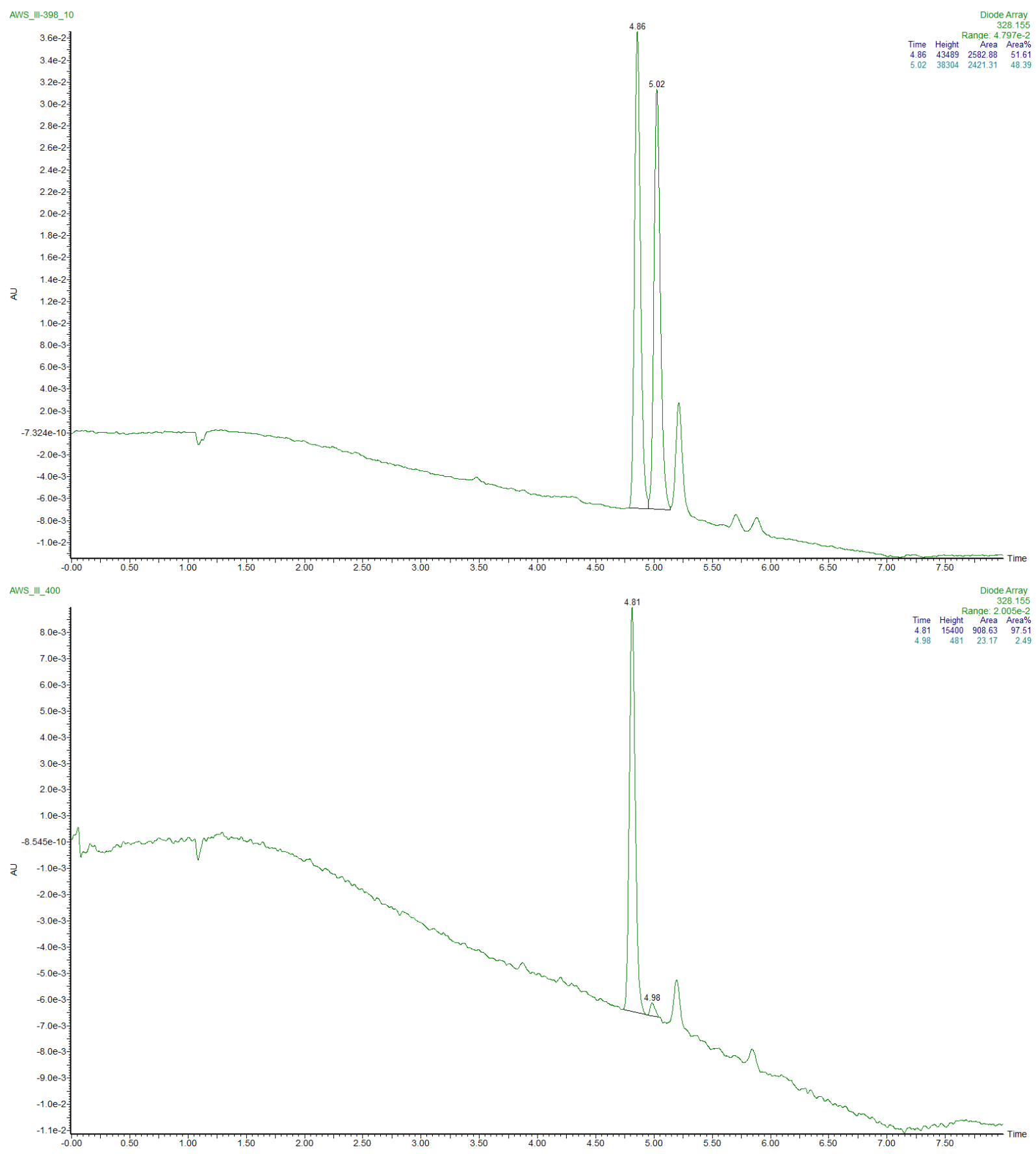


Supporting Information

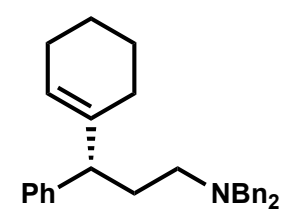

\section{$3 w$}
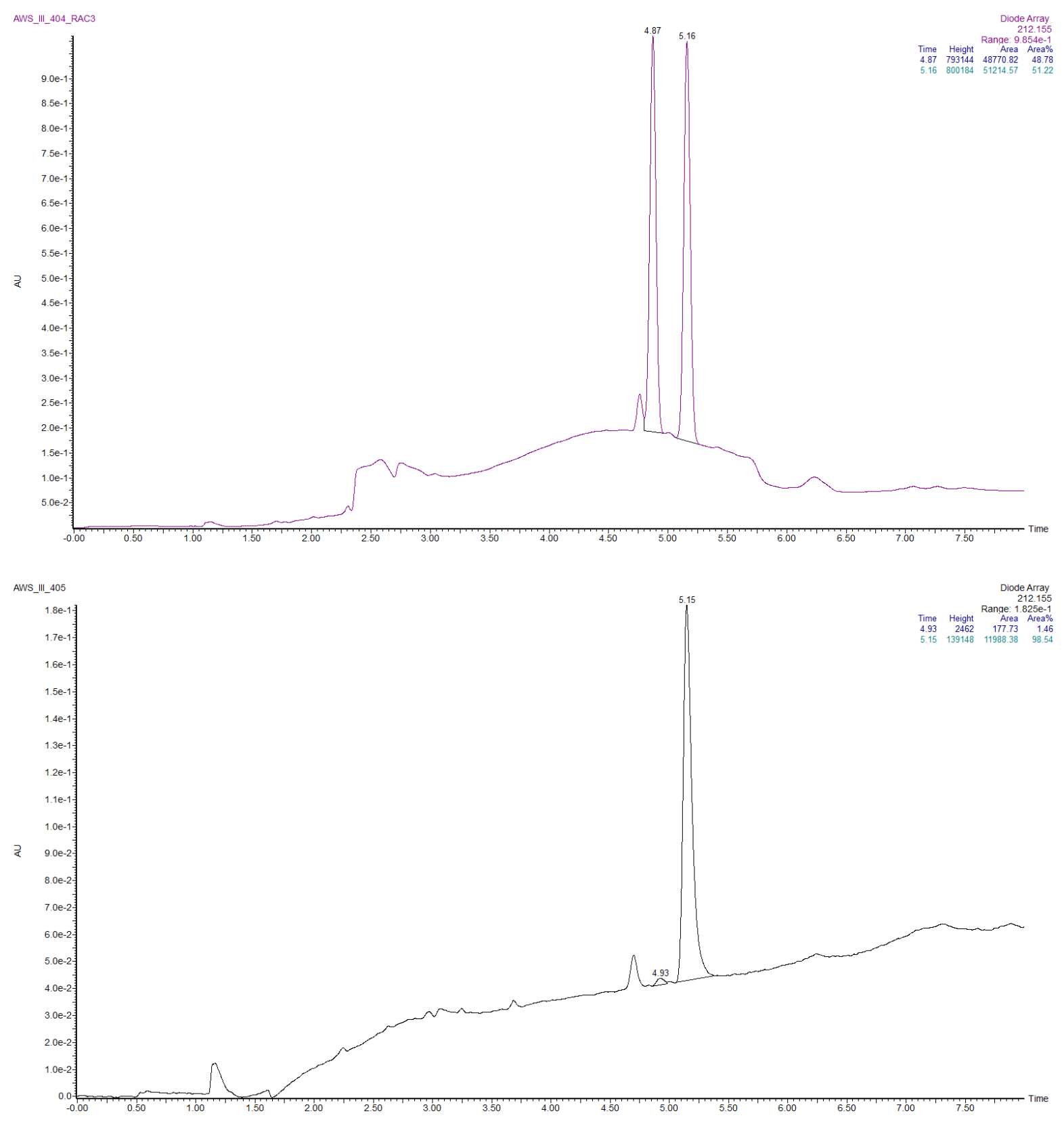


\section{Supporting Information}

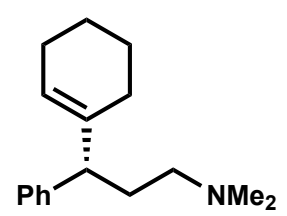

$3 x$

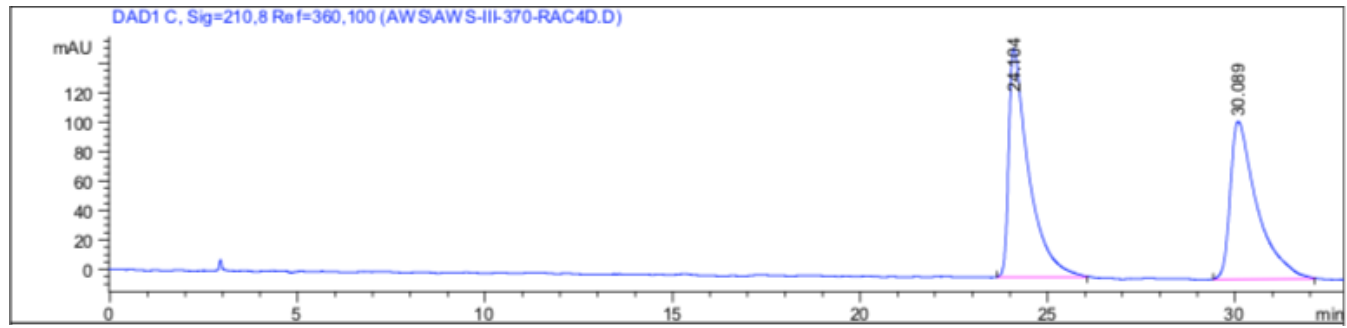

Signal 3: DAD1 C, Sig=210,8 Ref $=360,100$

\begin{tabular}{|c|c|c|c|c|c|c|}
\hline $\begin{array}{c}\text { Peak } \\
\neq\end{array}$ & $\begin{array}{c}\text { RetTime } \\
\text { [min] }\end{array}$ & Type & $\begin{array}{l}\text { Width } \\
\text { [min] }\end{array}$ & $\begin{array}{c}\text { Area } \\
{[\mathrm{mAU} * \mathrm{~s}]}\end{array}$ & $\begin{array}{l}\text { Height } \\
\text { [mAU] }\end{array}$ & $\begin{array}{c}\text { Area } \\
:\end{array}$ \\
\hline & & & -- & 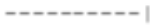 & $---1-1-4$ & --- \\
\hline 1 & 24.104 & BB & 0.5177 & 5755.32813 & 155.53026 & 52.0172 \\
\hline 2 & 30.089 & $\mathrm{BB}$ & 0.7009 & 5308.95654 & 107.36235 & 47.9828 \\
\hline
\end{tabular}

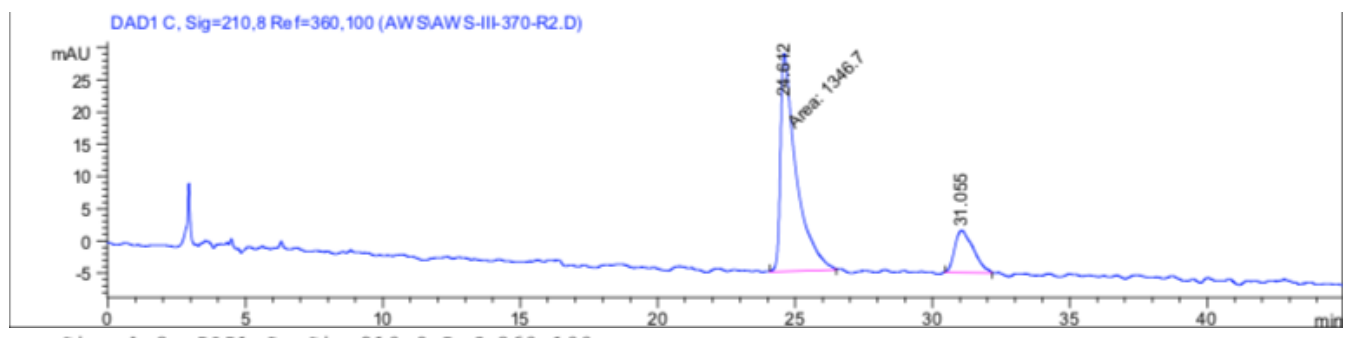

Signal 3: DAD1 C, Sig=210, 8 Ref $=360,100$

\begin{tabular}{|c|c|c|c|c|c|c|}
\hline $\begin{array}{c}\text { Peak } \\
;\end{array}$ & $\begin{array}{c}\text { RetTime } \\
\text { [min] }\end{array}$ & Type & $\begin{array}{l}\text { Width } \\
\text { [min] }\end{array}$ & $\begin{array}{c}\text { Area } \\
{\left[m A U^{*} s\right]}\end{array}$ & $\begin{array}{l}\text { Height } \\
\text { [mAU] }\end{array}$ & $\begin{array}{c}\text { Area } \\
\frac{8}{6}\end{array}$ \\
\hline 1 & 24.612 & MM & 0.6625 & 1346,70190 & 33.87826 & 81.3575 \\
\hline 2 & 31.055 & $\mathrm{BB}$ & 0.6086 & 308.58633 & 6.56229 & 18.6425 \\
\hline
\end{tabular}

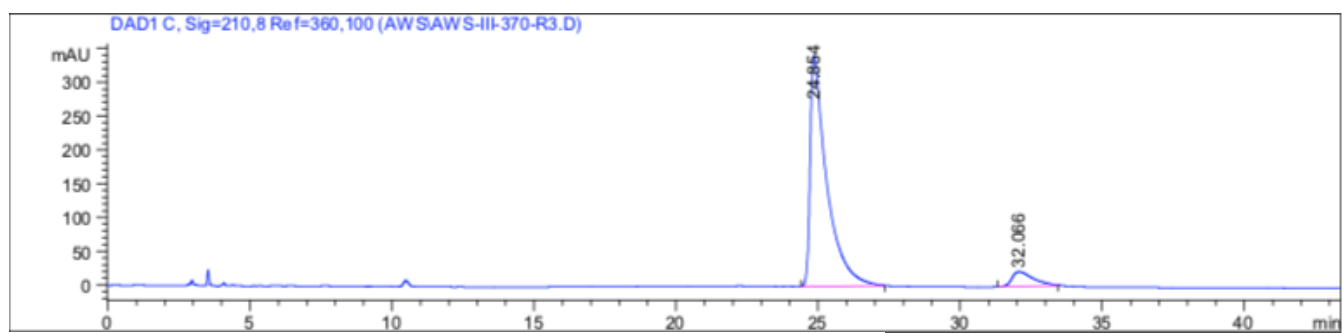

Signal 3: DAD1 C, Sig=210, 8 Ref $=360,100$

\begin{tabular}{|c|c|c|c|c|c|c|}
\hline $\begin{array}{c}\text { Peak } \\
;\end{array}$ & $\begin{array}{l}\text { RetTime } \\
\text { [min] }\end{array}$ & Type & $\begin{array}{l}\text { Width } \\
\text { [min] }\end{array}$ & $\begin{array}{c}\text { Area } \\
\text { [mAU*s] }\end{array}$ & $\begin{array}{l}\text { Height } \\
\text { [mAU] }\end{array}$ & $\begin{array}{c}\text { Area } \\
\frac{8}{6}\end{array}$ \\
\hline . & -1 & & - & $-2-2-2-1$ & 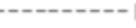 & - \\
\hline 1 & 24.854 & BB & 0.5620 & $1.38287 e 4$ & 341.78882 & 92.4097 \\
\hline 2 & 32.066 & $\mathrm{BB}$ & 0.7270 & 1135.85999 & 21.83091 & 7.5903 \\
\hline
\end{tabular}




\section{Supporting Information}
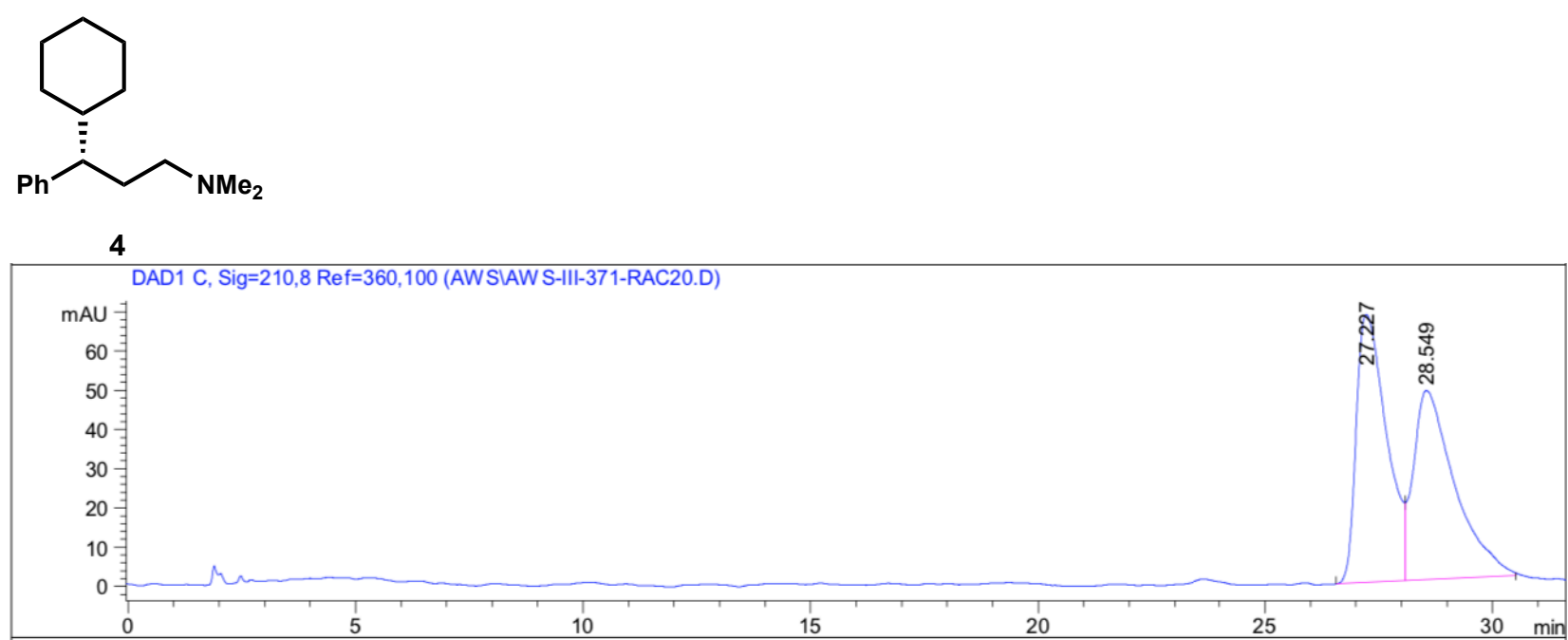

Signal 3: DAD1 C, Sig=210,8 Ref $=360,100$

Peak RetTime Type Width Area Height Area

\# $[\mathrm{min}] \quad[\mathrm{min}] \quad[\mathrm{mAU} * \mathrm{~S}] \quad[\mathrm{mAU}] \quad \frac{\circ}{0}$

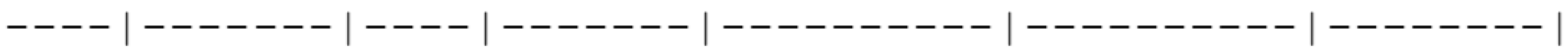
$1 \quad 27.227$ BV
0.69503157 .47974
68.3395150 .7571
$228.549 \mathrm{VB}$
0.88913063 .29053
$48.22462 \quad 49.2429$

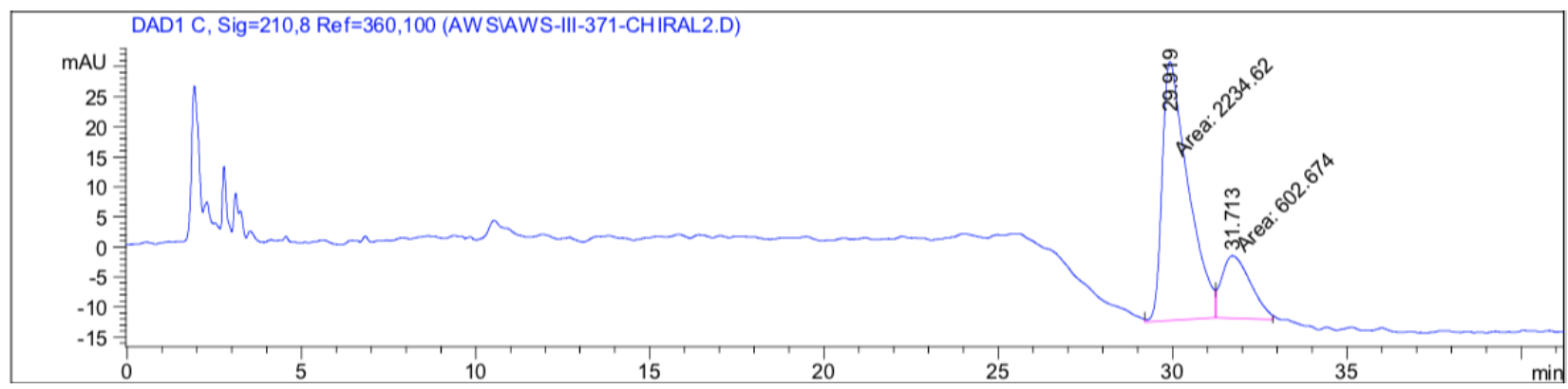

Signal 3: DAD1 C, Sig=210,8 Ref $=360,100$

\begin{tabular}{|c|c|c|c|c|c|c|}
\hline $\begin{array}{c}\text { Peak } \\
\quad \#\end{array}$ & $\begin{array}{c}\text { RetTime } \\
\text { [min] }\end{array}$ & Type & $\begin{array}{l}\text { Width } \\
\text { [min] }\end{array}$ & $\begin{array}{c}\text { Area } \\
{\left[\mathrm{mAU}^{*} \mathrm{~S}\right]}\end{array}$ & $\begin{array}{l}\text { Height } \\
{[\mathrm{mAU}]}\end{array}$ & $\begin{array}{c}\text { Area } \\
\frac{\circ}{0}\end{array}$ \\
\hline & & & & ---------- & --------- & -------- \\
\hline 1 & & & & 2234.61816 & 43.01926 & 7588 \\
\hline 2 & 13 & & & 602.67450 & 39215 & 2412 \\
\hline
\end{tabular}


Supporting Information<smiles>C[C@H](C1=CCCCC1)c1ccc(-c2ccccc2)cc1</smiles>

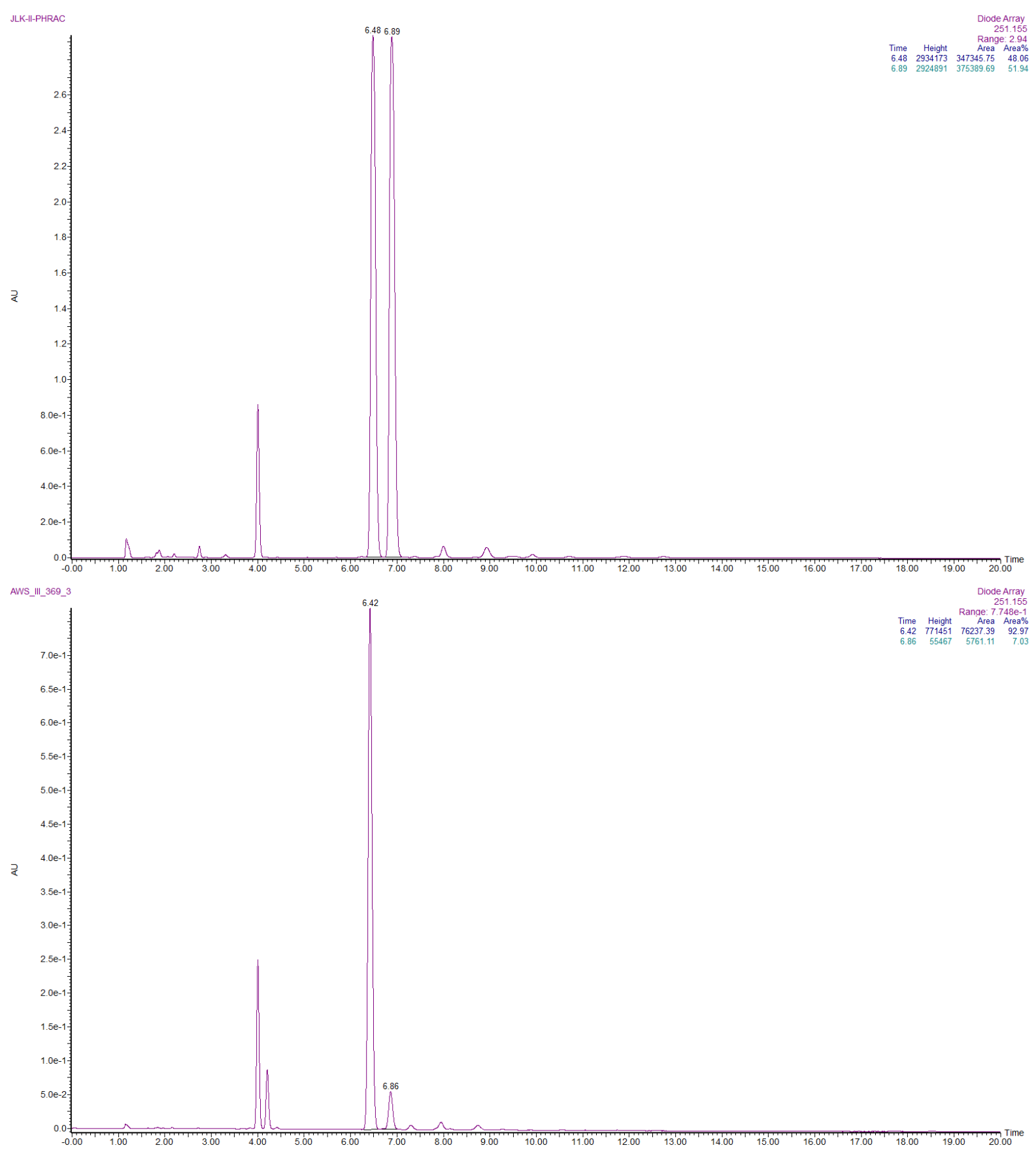

